\title{
CARACTERIZAÇÃO MORFOLÓGICA, FÍSICA, QUÍMICA E MINERALÓGICA DE REJEITOS DE MINERAÇÃO DE CALCÁRIO DA FORMAÇÃO IRATI - REGIÃO DE PIRACICABA (SP)
}

\author{
NORBERTO CORNEJO NORONHA \\ Engenheiro Agrônomo
}

Orientador: Prof. Dr. CELSO AUGUSTO CLEMENTE

\begin{abstract}
Dissertação apresentada à Escola Superior de Agricultura "Luiz de Queiroz", Universidade de São Paulo, para a obtenção do Título de Mestre em Agronomia, Área de Concentração: Solos e Nutrição de Plantas.
\end{abstract}

\footnotetext{
PIRACICABA

Estado de São Paulo - Brasil

Setembro - 1999
} 
Dados Internacionais de Catalogação na Publicação (CIP)

DIVISĀO DE BIBLIOTECA E DOCUMENTAÇĀO - Campus "Luiz de Queiroz"/USP

Noronha, Norberto Cornejo

Caracterização morfológica, fisica, química e mineralógica de rejeitos de mineração de calcário da Formação Irati - Regiāo de Piracicaba (SP) / Norberto Cornejo Noronha. - - Piracicaba, 1999.

159 p. : il.

Dissertação (mestrado) - Escola Superior de Agricultura Luiz de Queiroz, 1999. Bibliografia.

1. Calcário 2. Folhelho 3. Formação do solo 4. Formação Irati 5. Mineração 6. Mineralogia 7. Morfologia 8. Propriedade físico-química 9. Resíduo I. Título

CDD 631.821 


\begin{tabular}{|c|c|c|c|}
\hline \multirow[b]{2}{*}{ Página } & \multirow[b]{2}{*}{ Linha } & \multicolumn{2}{|c|}{ Errata } \\
\hline & & Onde se lê & Leia-se \\
\hline ix & 1 & an & $\mathrm{a}$ \\
\hline ix & 1 & mede & made \\
\hline ix & 10 & bancks & banks \\
\hline 3 & 9 & Assistênica & Assistência \\
\hline 11 & 12 & Down (1977 b) & Down (1975 b) \\
\hline 18 & 18 & levada & elevada \\
\hline 29 & 12 & $(<20 \mathrm{~cm})$ & $(>20 \mathrm{~cm})$ \\
\hline 46 & 25 & (14 anos) & (15 anos) \\
\hline 72 & 6 & $\mathrm{mmol}_{\mathrm{c}} \mathrm{cm}^{-3}$ & $\mathrm{mmol}_{\mathrm{c}} \mathrm{dm}^{-3}$ \\
\hline 93 & 1 & página 55 & página 49 \\
\hline 93 & 2 & página 121 & página 112 \\
\hline 96 & & Figura 55 & Figura 54 \\
\hline 96 & & Figura 56 & Figura 55 \\
\hline 97 & 2 & figura 61 & figura 55 \\
\hline 102 & & perfil P15 & perfil P2 \\
\hline 110 & 14 e 15 & foto $5 \mathrm{~B}$ na página 55 & foto $5 \mathrm{C}$ na página 49 \\
\hline 110 & 18 & $\mathrm{~mm}$ & em \\
\hline 110 & 12 & $7,56,5,27$ e 3,80 & 7,56 e 3,80 \\
\hline 114 & 21 & $2 \mathrm{~B}$ e $2 \mathrm{C}$ & $2 \mathrm{~A}$ \\
\hline 114 & 21 e 22 & $77 \mathrm{~B}$ e $77 \mathrm{C}$ & $77 \mathrm{~A}$ \\
\hline 152 & 12 & calcário, sílex e argilito & calcário com sílex \\
\hline
\end{tabular}


Minha homenagem à

\title{
Maria Candelária Cânovas Cornejo
}

\author{
A meus pais: Nastácio e Maria \\ e irmãos: Marcelo e Nicécio \\ DEDICO
}




\section{AGRADECIMENTOS}

Ao professor Dr. Celso Augusto Clemente, pela orientação, incentivo e apoio em todas as horas.

À Escola Superior de Agricultura "Luiz de Queiroz - USP, pelas condições oferecidas para o desenvolvimento do trabalho.

À coordenadoria de Aperfeiçoamento de Pessoal de Ensino Superior (CAPES), pela concessão da bolsa de estudo.

À empresa Amaral Machado e ao Senhor Oswaldo Antônio Silvestrini, pela concessão da área para o desenvolvimento deste estudo.

À Professora Dra. Célia Regina Montes Lauar pelo apoio.

Ao corpo técnico: Maria Elisabete H. B. Guimarães, Luciano Dias Ferraz, Wladmir Rosignolo e Ney Pinheiro, pelo apoio técnico, companheirismo e dedicação.

Aos amigos: Walter Geremias Robles, Marcelino Guedes, Ana Cláudia Lira, Cristina Lacerda, Silvia E. Farias e Geane C. Portela, pela amizade e companheirismo em todas as horas. 
SUMÁRIO Página

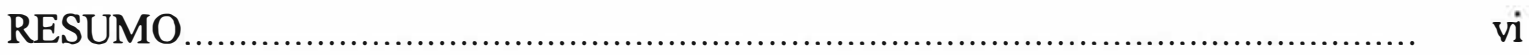

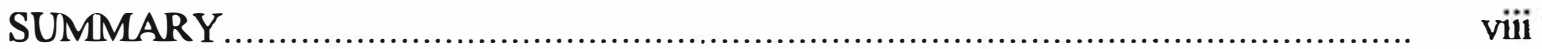

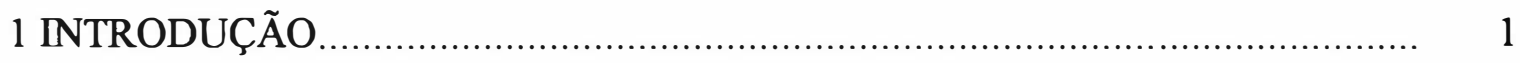

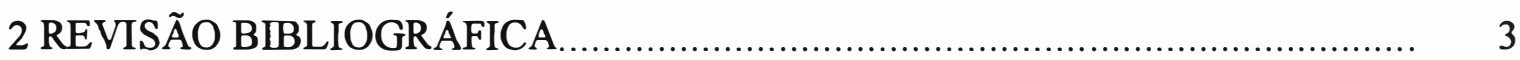

2.1 A presença de horizontes em solos de mina .................................................... 4

2.2 Caracterização fisica....................................................................... 5

2.3 Caracterização química........................................................................... 7

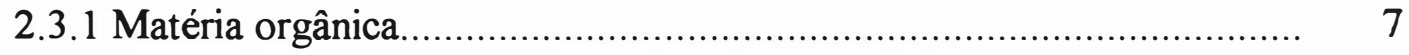

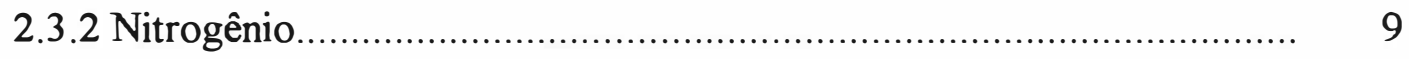

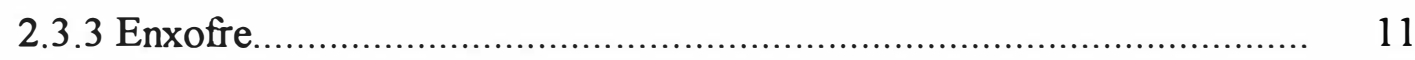

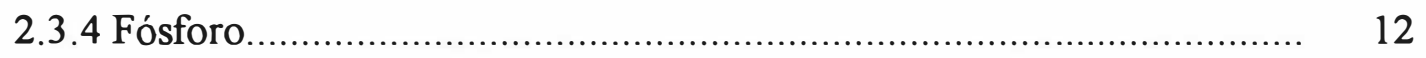

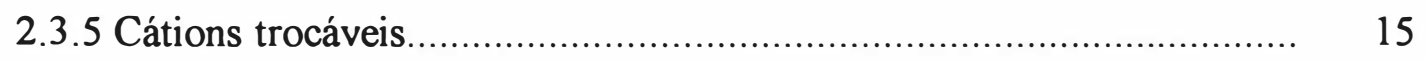

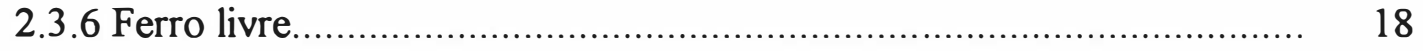

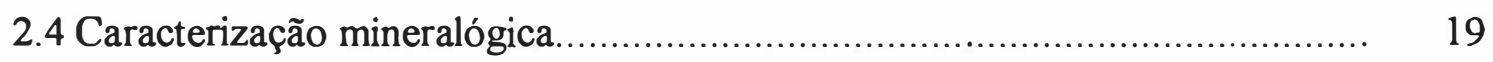

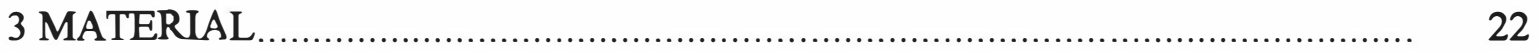

3.1 Localização da área e situação do perfil de extração..................................... 22

3.2 Caracterização dos bancos de rejeito........................................................... 25

3.2.1 Descrição morfológicas das trincheiras.............................................. 26

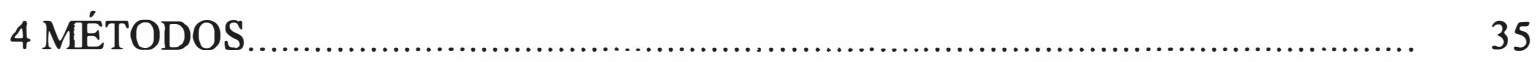

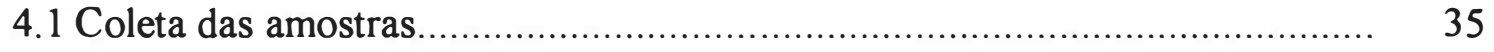

4.2 Procedimentos analíticos de laboratório..................................................... 35

4.2.1 Análise fisica.......................................................................... 35 


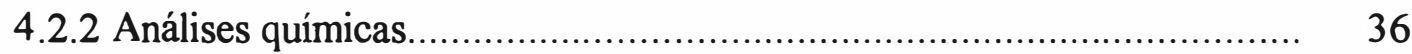

4.2.2.1 Análise química para fins de fertilidade .................................. 36

4.2.2.2 Ferro livre (amorfo e cristalino)........................................... 36

4.2.2.3 Ataque sulfúrico e determinação dos índices de intemperismo $\mathrm{Ki}$ e $\mathrm{Kr}$

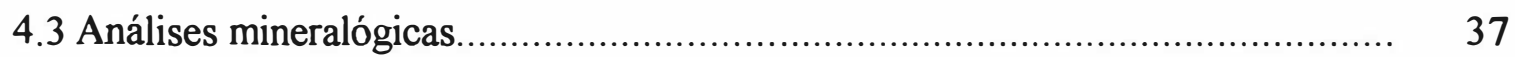

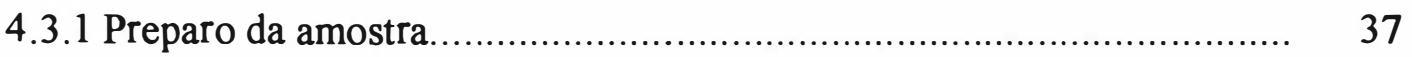

4.3.2 Microscopia petrográfica .......................................................... 37

4.3.3 Difratometria de raios-X........................................................ 37

4.4.4 Análise micrográfica.............................................................. 38

4.4 Análises micromorfológicas.................................................................. 38

5 RESULTADO E DISCUSSÃO .................................................................. 39

5.1 Caracterização dos perfis e formação dos solos sobre os rejeitos de mina de calcário

5.1.1 Trincheira P1 no banco de 2 anos................................................... 42

5.1.2 Trincheira P2 no banco de 15 anos.................................................. 45

5.1.3 Trincheira P3 no banco de 32 anos................................................... 50

5.1.4 Trincheira P4 no banco de 32 anos................................................... 53

5.1.5 Trincheira P5 no banco de 32 anos................................................... 55

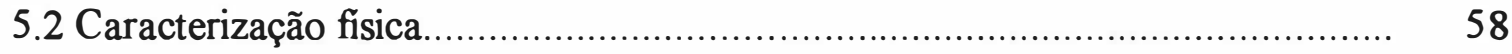

5.2.1 Frações TFSA (<2mm), cascalhos (2 a $20 \mathrm{~mm})$ e calhaus $(20$ a 50 $\mathrm{mm})$...

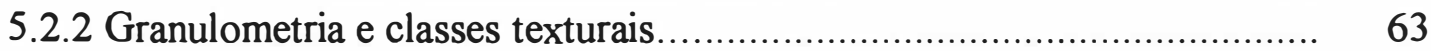

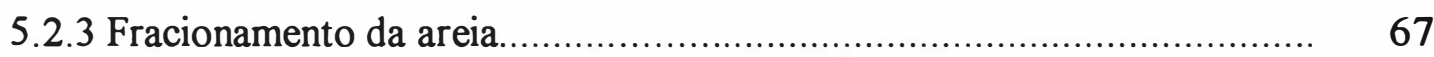

5.3 Caracterização química...................................................................... 70

5.3.1 Fertilidade dos solos de mina........................................................ $\quad 70$

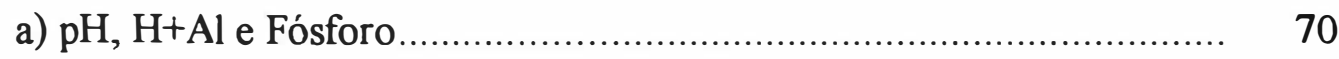

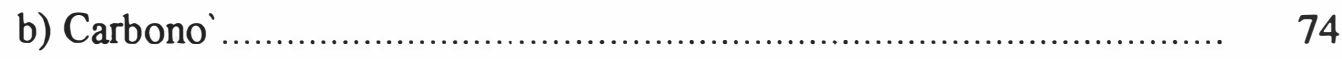

b.1) Carbono total............................................................... 75 
b.2) Carbono orgânico.............................................................. 78

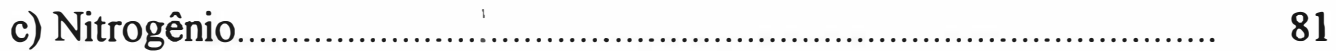

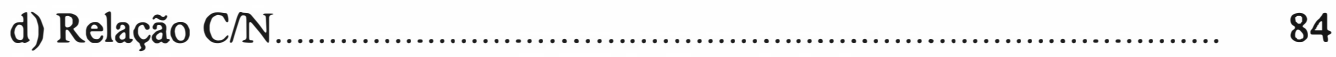

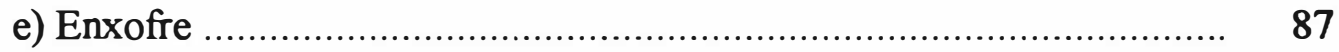

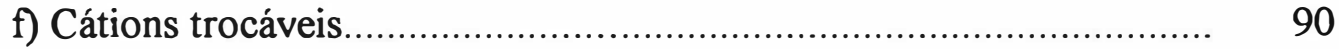

f.1) Cálcio e magnésio........................................................... 90

f.2) Potássio e sódio............................................................. 95

g) Soma de bases (S), capacidade de troca catiônica (CTC) e porcentagem de saturação de bases $(\mathrm{V} \%)$...................................... 98

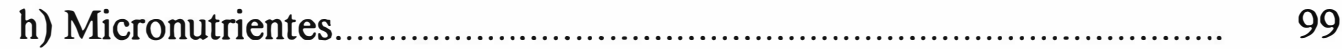

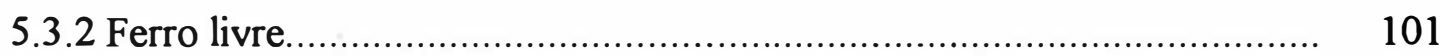

5.3.3 Ataque sulfúrico e alcalino e índices de intemperismo (Ki e Kr)............. 103

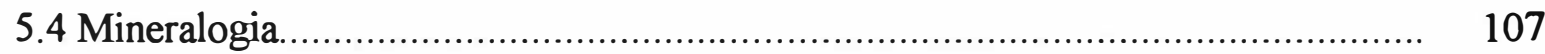

5.4.1 Observação da fração areia feita em lupa binocular e no microscópio petrográfico.

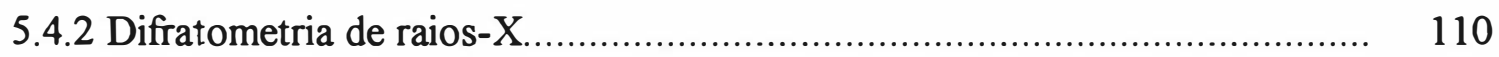

5.4.3 Observações micrográficas dos horizontes minerais superficiais................. 129

6 CONSIDERAÇÕES FINAIS SOBRE OS SOLOS EM FORMAÇÃO SOBRE REJEITOS DE MINERAÇÃO DE CALCÁRIO_............................................ 134

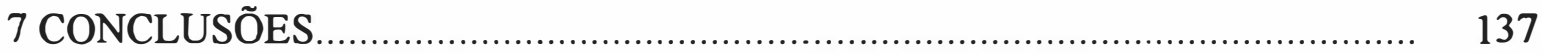

REFERÊNCIAS BIBLIOGRÁFICAS.......................................................... 138

ANEXOS Al - Caracterização morfológica de perfis de solos em formação sobre rejeitos de mineração de calcário 


\title{
CARACTERIZAÇÃo MORFOLÓGICA, FÍSICA, QUÍMICA E MINERALÓGICA DE REJEITOS DE MINERAÇÃO DE CALCÁRIO DA FORMAÇÃO IRATI - REGIÃO DE PIRACICABA (SP)
}

\author{
Autor: NORBERTO CORNEJO NORONHA \\ Orientador: Prof. Dr. CELSO AUGUSTO CLEMENTE
}

\section{RESUMO}

Com o objetivo de fazer uma caracterização preliminar dos rejeitos de mineração de calcário e de observar a evolução deste material em função do tempo, foi escolhida uma jazida de calcário pertencente à Formação Irati (Permiano) no município de Saltinho - SP. Foram selecionados 3 montes de deposição de rejeitos com 2, 15 e 32 anos. $\mathrm{O}$ monte de 2 anos é formado por fragmentos de folhelhos e calcários com sílex e blocos argilosos. Os de 15 e 32 anos são constituídos principalmente de fragmentos de folhelhos e calcários com sílex.

Foram abertas 5 trincheiras: Uma no monte de 2 anos (P1) sobre a cobertura de transição entre gramíneas e leucena, uma no monte de 15 anos (P2) sobre a cobertura de leucena e três no monte de 32 anos (P3, P4 e P5), sendo duas delas sobre a cobertura de leucena (P3 e P4) e uma terceira (P5) sobre a cobertura de pastagem consorciada gramíneas/leucena. Observou-se a ocorrência de horizonte A com $3 \mathrm{~cm}$ de espessura e com estrutura granular predominantemente fraca em P1 (2 anos). Nos montes formados por fragmentos rochosos, a estruturação não foi evidenciada em P2 (15 anos) e 
somente no monte com 32 anos observou-se o horizonte A com cerca de $3 \mathrm{~cm}$ de espessura. Os principais resultados obtidos apontam uma evolução da estrutura mais acelerada no banco onde os fragmentos rochosos são mesclados com material argiloso.

As análises de granulometria apontam que ocorre rápida fragmentação das rochas próximo à superficie dos bancos e as análises químicas indicam lixiviação de $\mathrm{Ca}$, $\mathrm{Na}$ e S-SO $\mathrm{SO}_{4}$ (salvo Ca em P1 (2 anos)) e aumento dos teores de K, do carbono orgânico e do nitrogênio na superficie de todos os perfis. Predomina pH ligeiramente ácido em todos os perfis. As concentrações de P, os valores de CTC e V\% são elevados em todos os perfis estudados. A fragmentação das rochas, o grau de estruturação na superficie destes montes, a lixiviação de $\mathrm{Ca}, \mathrm{Na}$ e $\mathrm{S}^{-\mathrm{SO}_{4}}$, a concentração de $\mathrm{P}$, o acúmulo de $\mathrm{K}$, carbono orgânico e nitrogênio são incrementados com a idade dos montes de rejeito.

A mineralogia predominante destes solos reflete a do material de origem. Predomina, na fração areia, fragmentos de folhelhos, calcário e sílex sendo que, na areia muito fina, encontra-se fragmentos de sílica amorfa, quartzo e alguns indícios de feldspatos e mica. Na fração silte, além do quartzo, encontram-se os feldspatos. A mica é melhor evidenciada na fração silte através das análises por MEV. A fração argila é composta principalmente de esmectita, seguida de ilita. Um argilo-mineral do tipo 1:1 é discretamente evidenciado, porém ocorre com maior nitidez nos horizontes superficiais dos perfis P2 (15 anos), P3, P4 e P5 (32 anos), sugerindo que esse mineral pode ter sido formado a partir do intemperismo de minerais presentes no material de origem. 


\title{
MORPHOLOGICAL, PHYSICAL, CHEMICAL AND MINERALOGICAL CHARACTERIZATION OF CALCAREUS MINE SPOILS OF THE IRATI FORMATION - REGION OF PIRACICABA (SP).
}

\author{
Author: NORBERTO CORNEJO NORONHA \\ Adviser: Prof. Dr. CELSO AUGUSTO CLEMENTE
}

\section{SUMMARY}

With the objective of doing a preliminary characterization of the calcareus mine spoil (Irati Formation - Permiane) and of observing the evolution of this material in function of time, a area of extraction of limestone in the municipal district of Saltinho (SP) was chosen. Three spoil banks were selected with 2, 15 and 32 years old. The 2 years old bank is formed of shale and limestone with silex rock fragments mixed with clay blocks. The 15 and 32 years old banks are basically formed mainly of fragments of shale and limestone cemented with silex.

Five pits were openned in the following banks: one in the 2 years old bank (P1) on a grass - leucena transition cover; one in the 15 years old banck (P2) on a leucena cover and three in the 32 year-old bank (P3, P4 and P5), being two of them on leucena (P3 and P4) and the third one (P5) on grasses/ leucena consorciation. We observed the occurrence of a weak granular structure A horizon with $3 \mathrm{~cm}$ of thickness in P1 (2 years). In the banks formed by rock fragments, no structure was evidenced in P2 (15 yars old) and only in the 32 years-old banks the A horizon was observed with about $3 \mathrm{~cm}$ of 
thickness. The main results show an faster evolution of the structure in the bank mede up of rock fragments mixed with clay materials.

The grannulometrical analysis show a fast fragmentation of the rocks occurring near the surface of the profiles and the chemical analyses indicate leaching of $\mathrm{Ca}, \mathrm{Na}$ and $\mathrm{S}_{-} \mathrm{SO}_{4}$ (safe $\mathrm{Ca}$ in $\mathrm{P} 1$ (2 years old)) and a increase of $\mathrm{K}$, organic carbon and nitrogen in the mine soil surface. The $\mathrm{pH}$ is lightly acid to lightly basic in all the profiles. The $\mathrm{P}$ concentration, $\mathrm{CEC}$ and $\mathrm{V} \%$ values are high in these mine soils. The rock fragmentation at the surface of these banks, the degree of structure development, the $\mathrm{Ca}$, $\mathrm{Na}$ and $\mathrm{S}_{-} \mathrm{SO}_{4}$ leaching, the increaseing $\mathrm{P}$ and $\mathrm{K}$ concentration, organic carbon and nitrogen acumulation increase with the age of the bancks.

The predominant mineralogy of these soils reflects the parental materials. Shale, limestone and silex fragments predominate in the sand fraction, and in the very fine sand, fragments of amorphous silica, quartz, few feldspates and traces of mica was observed. Besides the quartz, feldspates are found in the silt fraction. Mica is better evidenced by SEM micrographs in the silt fraction. The clay fraction is composed mainly of smectite, followed by ilite. A small 1:1 clay mineral peak was indentified. This peak appears only in the superficial horizons of the P2 (15 years old), P3 P4 and P5 (32 years old) profiles and it suggests that this mineral can be formed from the weathering of minerals presents in the parental rocks. 


\section{INTRODUÇÃO}

A atividade de mineração causa evidentes impactos ambientais modificando a paisagem e alterando as condições de solo, água, vegetação e fauna. Isto se deve pelo fato que, para a extração do minério, é retirada a vegetação natural além da camada de solo fértil e as vezes se faz necessário a remoção de mantos rochosos que não possuem valor econômico.

Com a finalidade de caracterizar os rejeitos de mineração de calcário e de observar a evolução deste material em função do tempo foi escolhida uma jazida de calcário no município de Saltinho - SP (empresa Amaral Machado), que está em atividade há mais de 30 anos. $\mathrm{O}$ calcário é explorado para a obtenção de corretivo agrícola.

O material de interesse econômico (calcário dolomítico, da Formação Irati - Permiano) está situado abaixo de uma camada de cerca de $21 \mathrm{~m}$ de rocha que se caracteriza por intercalação de camadas de calcário com sílex e folhelhos carbonosos pirobetuminosos, argilitos, folhelhos e siltitos em alteração, bem como solo. Para a exploração do calcário é necessária a retirada desse material sobrejascente. O material retirado é empilhado em bancos de deposição de rejeito e está sujeito a ação intempérica e pedogenética. Sobre estes bancos de deposição, em uma primeira visita, foi observado a predominância de uma vegetação invasora, pioneira de uma leguminosa, da família mimosaceae, do gênero Leucaena, denominada comumente no Brasil como Leucena (Leucaena leucocephala). Os frutos são vagens e encerram sementes leves e achatadas que com a deiscência, se espalham na área. $O$ formato achatado das sementes permite que estas ocupem frestas nos escombros onde provavelmente encontram abrigo para a germinação. 
A leucena muitas vezes sucede outros tipos de formação vegetal. Foi observado que em alguns sítios a colonização inicial muitas vezes fica por conta de algumas herbáceas das famílias Poaceae, Asteraceae, Malvaceae, Fabaceae, Amarantaceae, Euphorbiaceae, e outras. Estas plantas foram observadas colonizando inicialmente áreas mais recentes de rejeito. Com o passar do tempo a leucena vai se estabilizando nestas áreas e acaba por dominar e, por ter um porte mais alto, reprime a antiga vegetação.

Com a intenção de acompanhar a alteração dos bancos de rejeito e o desenvolvimento pedogenético dos mesmos em função da idade, propõe-se um estudo visando caracterizar fisica (granulometria), química e mineralogicamente o material de rejeito da mineração de calcário e relacionar a evolução dos montes de diferentes idades, tipos de materiais e formas de estoque dos rejeitos.

Para iniciar o presente estudo, algumas hipóteses foram lançadas:

1- Os rejeitos de diferentes idades poderiam apresentar características fisicas, químicas e mineralógicas diferentes;

2- O arranjo estrutural das diferentes rochas que compõem o rejeito dificultaria a formação de horizontes.

3- Os rejeitos constituídos basicamente de materiais rochosos teriam evolução diferenciada dos rejeitos formados por material rochoso misturado a materiais argilosos. 


\section{REVISÃO BIBLIOGRÁFICA}

Para elaborar uma proposta de recuperação de rejeitos de mineração de calcário, é de fundamental importância o conhecimento do material designado como rejeito tanto na sua fase inalterada, rocha sã, como na fase que se apresenta em processos de alteração, quando esse material é removido e armazenado nos depósitos. As informações dos programas de solos e rejeitos podem ser integradas para otimizar a eficiência do manejo e alcançar os objetivos da recuperação (Schori et al., 1989).

Soave (1996), cita que a Formação Irati pertencente ao Grupo Passa Dois, Membro Assistênica, é constituída litologicamente de uma alternância rítmica de folhelhos pretos, pirobetuminosos e calcários dolomíticos creme a cinza escuro que, às vezes, pode se apresentar com sílex e pirita finamente dividida.

Embora muitas empresas atuaram ou ainda atuam na exploração do calcário da Formação Irati, há pouco material literário disponível quanto a caracterização dos rejeitos proveniente de sua exploração. Assim fica evidente a carência de informações sobre estes rejeitos que poderiam ser úteis no planejamento da reabilitação dessas áreas de mineração de calcário.

Uma caracterização geotécnica foi feita por Paraguassú et al. (1983), que coletaram cerca de 4 toneladas de rejeitos de calcário da Formação Irati e identificaram 6 tipos de materiais de rejeito: 1- Folhelho silicoso arenoso carbonático; 2- calcário dolomítico com concreções silicosas; 3- calcário dolomítico bandado com leitos de sílex; 4- calcário dolomítico laminado com concreções silicosas; 5- calcário dolomítico laminado escuro (rico em hidróxidos e óxidos de ferro); 6- calcário dolomítico bandado à laminado. Também as propriedades geotécnicas dos rejeitos da mineração de calcário da Formação Irati são apresentadas por Menegon (1990). 
Devido à diversidade quanto à natureza e à forma do material, o rejeito é caracterizado por apresentar propriedades fisicas e químicas bastante heterogêneas. Os materiais de rejeito da mineração de calcário, uma vez estocados nas áreas de estéreis, estão sujeitos à ação intempérica e pedogenética e, devido à natureza química do rejeito, é possível que os materiais piríticos oxidem conjuntamente à dissolução dos carbonatos levando a formação de gesso (Ritsema et al., 1993, Doolittle et al., 1993). De fato, Almeida (1983), observou a presença de $\mathrm{CaSO}_{4}$ cristalizado em alguns perfis abertos em solos de mina formados sobre o rejeito da mineração de calcário da Formação Irati em Rio Claro.

\subsection{A presença de horizontes em solos formados sobre rejeito de mina}

$\mathrm{Na}$ região de Rio Claro (SP), Almeida (1983) caracterizou perfis em montes de rejeitos de calcário que variavam de entre 2,5 a 30 anos e relatou a ocorrência de um horizonte $\mathrm{AC}$ de $3 \mathrm{~cm}$ de espessura, seguido de um horizonte $\mathrm{C}$ em uma área de 2,5 anos. O autor infere que a evolução pedogenética de solos desenvolvidos sobre rejeitos de calcário da Formação Irati está relacionada ao tempo e ao clima. Nos meses chuvosos houve predomínio do intemperismo químico sobre o fisico ou biológico e nos meses secos e mais frios ocorreu um predomínio do intemperismo fisico sobre o químico e biológico; quanto a sua classificação, com base em outros autores, propõem que estes solos sejam classificados como pertencentes à ordem dos "Entsolos" e à sub ordem "Spolent".

Também na região de Rio Claro (SP), Soave (1996) estudou as características de formação dos solos e desenvolvimento da vegetação em 5 áreas de rejeito de mineração de calcário da Formação Irati, com idade variando de 9 a 37 anos e em uma área que recebeu recobrimento dos rejeitos com materiais da Formação Corumbataí. A autora notou a existência de horizontes $\mathrm{A}$ em todas as áreas estudadas e a presença de um horizonte Bw na área mais antiga (37 anos), o que sugere uma tendência de desenvolvimento do solo com o tempo. 
Segundo Wilson (1957), o tipo de vegetação em rejeitos é um importante fator na agregação, sendo que gramíneas e leguminosas forrageiras promovem mais rápido desenvolvimento da agregação em solos de mina que árvores. $\mathrm{O}$ enraizamento das plamtas também colabora para a formação de estrutura em solos de mina (Roberts et al., 1988 b).

Para Roberts et al. (1988 a) e Varela et al. (1993), as rápidas mudanças nas propriedades dos solos de mina são o resultado da atividade dos processos pedogenéticos sobre o material geológico recentemente exposto que não está inicialmente em equilíbrio com o ambiente de superficie.

Roberts et al. (1988 a) ainda concluem que a dissolução, a lixiviação, a oxidação, a incorporação e decomposição da matéria orgânica e os ciclos de expansão e contração são processos que transformam as propriedades superficiais dos solos de mina em um período de tempo relativamente curto. Para estes autores, a produtividade de um solo e a taxa com a qual as propriedades dos solos mudam tem grande importância para o sucesso da reabilitação e outros sistema de manejo da área.

\subsection{Caracterização física}

\section{A granulometria no solo de mina}

A rochosidade é uma característica comum na maioria dos solos de mina. Pedersen et al. (1980), estudando a superficie de uma área de mineração de carvão, cujos rejeitos eram formados por fragmentos de arenito e folhelhos, encontraram valores elevados de pedregosidade, variando de $64 \%$ em horizontes A até $93 \%$ em horizontes C.

Ciolkosz et al. (1985), analisaram 24 solos em evolução sobre rejeitos de mineração e relataram que o conteúdo de fragmentos grossos variaram entre 40 a $60 \%$ na superficie e acima de $70 \%$ no subsolo. De acordo com os autores, os fragmentos rochosos quebram-se em fragmentos menores e material de terra $(<2 \mathrm{~mm})$ na superficie do solo rapidamente e particularmente os folhelhos se desagregam logo nos primeiros anos de intemperismo. 
Roberts et al. (1988 a), encontraram fragmentos grosseiros (>2 $\mathrm{mm}$ ) variando entre valores de 64 a $79 \%$, sendo que foi observado que os fragmentos grossos na camada superficial de $0-5 \mathrm{~cm}$ decresciam visivelmente com o tempo devido a intemperização destes fragmentos.

É destacável a problemática de escombros formados por folhelhos, constituídos em mais de $90 \%$ de seu volume por blocos de grande tamanho, principalmente no que se refere ao assentamento imediato da vegetação, mas a intemperização deste material é bastante rápida e em poucos anos pode incrementar-se de forma considerável o material coloidal (Monterroso-Martinez, 1995; Quintas-Mosteiro, 1997).

Monterroso-Martinez (1995) estudou várias áreas de mineração na Galícia e percebeu que, em rejeitos formados por folhelhos, algumas áreas podem apresentar um ligeiro grau de agregação a 5 ou $10 \mathrm{~cm}$ superficial e apesar da rochosidade ou compactação, pode-se constatar o desenvolvimento de sistemas radiculares de plantas superiores.

Os fragmentos de folhelho se alteram rapidamente em material de solo (< $2 \mathrm{~mm}$ ) próximo à superficie dos solos de mina (Schafer et al., 1980), resultando na redução dos cascalhos e aumento das frações areia e argila (Jonhson et al., 1982).

Através de uma simulação de intemperismo de folhelhos, Hower et al. (1992) encontraram aumentos de 9 a $35 \%$ na fração $<2 \mathrm{~mm}$, sendo que a maioria desse incremento ocorreu na fração silte.

A existência de cascalhos e rochas podem desempenhar um papel positivo nos solos de mina através da criação de vias para a entrada e circulação de água e ar (Smith et al., 1971, citados por Quintas-Mosteiro, 1997).

O maior aprofundamento das raízes em solos arenosos, pode compensar a diminuição do volume das mesmas devido a presença de pedras. Além disso, a medida que se avança o intemperismo e a desagregação da rocha, criam-se espaços para o enraizamento e canais para a circulação de água e ar (Ashby, et al., 1984, citado por Quintas-Mosteiro, 1997). 
Apesar de Bell et al. (1994) relatarem que camadas com mais de 50\% de fragmentos rochosos podem restringir o crescimento vegetal devido a uma diminuição na capacidade de retenção de água, vários autores têm evidenciado que fragmentos rochosos maiores que $2 \mathrm{~mm}$ podem ainda contribuir com outro aspecto favorável aos atributos físicos dos solos de mina pois as frações grossas podem reter umidade e ser responsável pelo fornecimento de água para as plantas nos solos pedregosos.

Segundo Coile (1952), há algum tempo se assumia que pequenas rochas não continham apreciáveis quantidades de água. Isso provavelmente é correto para cascalhos de quartzo mas não é necessariamente certo no que se refere à rochas compostas de outros minerais em vários estágios de alteração. $\mathrm{O}$ autor demonstrou que as rochas contribuem no suprimento de água para as plantas e isso depende do tipo, tamanho e concentração dos fragmentos rochosos no solo.

A água disponível em fragmentos grossos pode desempenhar um significativo papel no crescimento de plantas em solos que contém alta porcentagem de fragmentos grossos, como em áreas de mineração (Hanson \& Blevins, 1979). Estes autores relataram fragmentos de fragmentos de folhelhos pretos apresentaram $17 \%$ de água disponível na fração 2 a $5 \mathrm{~mm}$ e $11 \%$ na fração 5 a $20 \mathrm{~mm}$ (considerando-se como água disponível a diferença entre a umidade na capacidade de campo e a umidade no ponto de murcha permanente, determinada através da extração pelas plantas em casa de vegetação).

Hower et al. (1992) expuseram folhelhos a 40 ciclos de congelamento e descongelamento para simular um intemperismo para posteriormente quantificar sua capacidade de armazenamento de água, encontrando 19\% de água disponível no produto derivado do intemperismo artificial.

\subsection{Caracterização química}

\subsubsection{Matéria orgânica}

De acordo com Quintas-Mosteiro (1997) os níveis de C e $\mathrm{N}$ em solos de mina dão uma idéia, mesmo que grosseira, do grau de evolução edáfica em que se 
encontram os materiais de rejeito. Os conteúdos de matéria orgânica e nitrogênio total são dependentes da existência de uma vegetação durante um período suficiente para haver acúmulo de restos vegetais que contribuem para criar uma reserva destes elementos.

O rápido aporte de carbono orgânico em solos de mina foi relatado por diversos autores. Schafer et al. (1980), Roberts et al. (1988 a e b), Chichester \& Hauser (1991) e Soave (1996), entre outros autores, evidenciaram o aporte de material orgânico em solos de mina com o tempo.

Varela et al. (1993), na superficie de solos da mineração de linhito, encontraram um rápido aporte de carbono orgânico de $1,3 \mathrm{~g} \mathrm{Kg}^{-1}$ a $50 \mathrm{~g} \mathrm{Kg}^{-1}$, como também um aporte de $0,36 \mathrm{~g} \mathrm{Kg}^{-1}$ a $1,3 \mathrm{~g} \mathrm{Kg}^{-1}$ de nitrogênio (em solos de 1 e 5 anos, respectivamente) e, baseado em vários autores, sugerem que o rápido acúmulo de matéria orgânica durante os primeiros anos de evolução é considerado como um típico processo de evolução edáfica dos solos de mina.

Também é importante se conhecer o carbono total existente no solo, mesmo em formas fosseis pois, após o intemperismo da rochas carbonosas ou decomposição de restos vegetais e animais, parte deste carbono pode contribuir para a melhora das propriedades dos solos de mina. De acordo com Varela et al. (1993) e Soave (1996), a matéria orgânica sofre rápido processo de humificação e os produtos finais da decomposição da matéria orgânica reagem com constituintes inorgânicos do solo, contribuindo para uma melhora de suas propriedades fisicas.

Em solos de mina, a liteira pode apresentar um pobre contato com o solo e, conforme Schafer et al. (1980), um pobre contato com o solo e um secamento rápido colaboram para o retardamento de sua decomposição.

Organismos do solo como minhocas podem incorporar material orgânico em profundidade e trazer material mineral à superficie dos solos (Throp (1949) citado por Thomas \& Jansen, 1985).

Além da acumulação de matéria orgânica em profundidade, formigas podem promover o transporte de materiais minerais da subsuperficie para a superficie dos 
solos promovendo a pedoturbação e homogeneização do solo (Hole, 1961; Mandel \& Sorenson, 1982), além de favorecer um maior contato entre o material orgânico e o material mineral.

A cobertura vegetal incrementa as diferenças morfológicas, químicas e biológicas dos solo (Alexander, 1986), mas a interpretação do carbono orgânico total de materiais de solos de mina é confundida pela presença de altas quantidades de material fóssil. A degradação do material fóssil tende mascarar os acréscimos nas quantidades de carbono recente proveniente das plantas (Chichester \& Hauser, 1991).

Anderson (1977), estudando a formação de solos sobre rejeitos de calcário, relata que pequenas inclusões de carvão mineral afeta o calculo da matéria orgânica baseada no carbono.

Para Roberts et al. (1988 b), estimar o conteúdo de matéria orgânica em solos de mina é complicado devido à oxidação do Fe e Mn que se apresentam reduzidos nos rejeito, bem como à traços de fragmentos de carvão mineral.

\subsubsection{Nitrogênio}

A deficiência de nitrogênio é um dos maiores fatores limitantes do crescimento de plantas em solos provenientes da atividade de extração mineral (Reeder \& Berg, 1977; Jefferies et al. 1981; Skeffington \& Bradshaw, 1981; Mcginnies \& Crofts, 1986).

Embora o estabelecimento de um ecossistema auto sustentável e estável dependa de uma efetiva ciclagem de vários macronutrientes, a acumulação de nitrogênio e a formação de um ciclo efetivo é importante pois este é o elemento mais rapidamente perdido do ecossistema.

$\mathrm{O}$ material de origem pode atuar como uma fonte de nitrogênio para o sistema em evolução nos solos de mina. Krechetova (1996), encontrou conteúdos de $\mathrm{N}$ variando entre $1 \mathrm{~g} \mathrm{Kg}^{-1}$ a $8 \mathrm{~g} \mathrm{Kg}^{-1}$ em folhelhos betuminosos.

O nitrogênio presente em rochas fósseis pode, muitas vezes, não se encontrar biologicamente disponivel. Cerca de $2 / 3$ do nitrogênio total de sedimentos ou 
rochas sedimentares está retido na forma de $\mathrm{NH}_{4}{ }^{+}$na estrutura dos minerais de argila, somente tornando-se disponível com a destruição da estrutura de argila (Stevenson, 1959).

As mais importantes formas biologicamente ativas de nitrogênio incluem o $\mathrm{NH}_{4}{ }^{+}$trocável (amônio absorvido pela capacidade de troca na superficie dos minerais de argila e as formas solúveis em água $\left(\mathrm{NO}_{2}{ }^{-2}\right.$ e $\mathrm{NO}_{3}{ }^{-}$) (Stevenson, 1962; citados por Power et al., 1974).

O nitrogênio orgânico presente em folhelhos também pode vir a sofrer mineralização, sendo que o intemperismo físico ou químico decorrente da ação de plantas e microorganismos pode favorecer esse processo (Reeder \& Berg, 1977).

Embora exista a possibilidade de aumento da disponibilidade de $\mathrm{N}$, favorecendo a revegetação durante o processo de restauração das pilhas de rejeitos de mineração, Power et al. (1974) advertem que quantidades apreciáveis de $\mathrm{NH}_{4}{ }^{+}$trocável, existentes nos folhelhos do Paleoceno podem sofrer rápida nitrificação, o que pode acarretar em um aumento de $\mathrm{NO}_{3}{ }^{-}$nas águas superficiais e no lençol freático quando vastas áreas desse material são expostas ou ainda recebem um manejo inadequado da água de irrigação.

Woodmansee (1978) adverte que, embora a rocha pode fornecer uma quantidade de nitrogênio às plantas nos primeiros estágios da recuperação de um solo de mina, com o decorrer do tempo os microrganismos e as plantas atuam como consumidores deste elemento, acentuando as deficiências de formas assimiláveis, o que poderá resultar na necessidade de um aporte externo deste elemento para suprir sua carência e possibilitando a decomposição e mineralização da matéria orgânica.

A carência de nitrogênio pode comprometer o estabelecimento de uma cobertura vegetal em áreas de mineração, mas em áreas onde os rejeitos de mineração são pobres em nitrogênio, as primeiras plantas colonizadoras são frequentemente leguminosas arbustivas (Dancer et al., 1977 a e b). 
A predominância de espécies fixadoras de nitrogênio $\mathrm{N}$ durante os primeiros estágios de sucessão de plantas torna possível o posterior crescimento de espécies não fixadoras (Crocker \& Major, 1955).

As leguminosas, portanto, são importantes colonizadoras de solos de mina (Roberts et al., 1981) e podem ser empregadas na fixação de nitrogênio nestes solos. Para Jefferies et al. (1981), o uso de leguminosas é considerado o mais eficiente meio de acumulação de nitrogênio em rejeitos de mineração, devendo-se considerar sua tolerância às condições extremas encontradas e seu potencial de acumular altas taxas de nitrogênio.

\subsubsection{Enxofre}

O enxofre em solos de mina pode ocorrer em uma ou mais formas minerais como a pirita $\left(\mathrm{FeS}_{2}\right)$, o sulfato de ferro $\left(\mathrm{FeSO}_{4}\right)$, gesso $\left(\mathrm{CaSO}_{4}\right)$ e sulfato de magnésio $\left(\mathrm{MgSO}_{4}\right)$, segundo Lawrence (1972), citado por Down (1977 b).

Além de presentes em formas minerais, o enxofre pode encontrar-se em formas orgânicas nos sedimentos rochosos. Krechetova (1996) encontrou altos conteúdos de enxofre no ácido húmico de folhelhos betuminosos, muitas vezes excedendo o conteúdo de nitrogênio.

$\mathrm{Na}$ descrição do material geológico constituinte do rejeito da mineração do calcário Irati, Soave (1996) relata que a pirita pode estar presente nas rochas calcários e nos folhelhos pirobetuminosos.

Monterroso-Martinez (1995) cita que a pirita pode se oxidar seguindo duas vias, a biológica e a química. Os problemas principais da oxidação deste mineral, conforme reportado pela autora são: a) a formação de um substrato extremamente ácido que impeça o estabelecimento vegetal e; b) a formação de uma drenagem ácida.

A drenagem ácida e solos com ácido sulfúrico ocorrem quando certos materiais com sulfeto são expostos à ambientes de oxidação na ausência de minerais calcários (Caruccio et al., 1988). No entanto esta geração ácida pode ser amenizada pela presença de materiais carbonáticos. Ritsema \& Groenenberg (1993) constataram que a 
geração ácida devido a drenagem de solos alagados contendo pirita e carbonatos provoca intemperização dos carbonatos.

A intemperização dos carbonatos previne a acidez gerada pela oxidação da pirita e formam sais precipitados como o $\mathrm{CaSO}_{4} \cdot 2 \mathrm{H}_{2} \mathrm{O}$. A progressiva oxidação da pirita gera $\mathrm{H}_{2} \mathrm{SO}_{4}$ e causa diminuição dos valores de $\mathrm{pH}$ que, por sua vez, promove dissolução

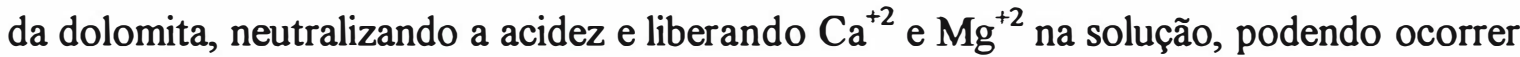
lixiviação de $\mathrm{Ca}^{+2} \mathrm{e} \mathrm{SO}_{4}^{-2}$ (Doolittle et al., 1993).

Geralmente se assume que a presença do gipso em solos sobre condições úmidas é frequentemente sazonal. Devido a sua alta solubilidade, o gipso se dissolve facilmente quando o solo está úmido e tende a persistir durante a estação seca (Ritsema \& Groenenberg, 1993). Também, quando o produto da atividade iônica do gipso é excedido, ocorre precipitações de cristais nos vazios do solo e ao longo de canais (Doolittle et al., 1993).

Almeida (1983) e Soave (1996) descreveram que cristais de gipso aparecem em perfis de solos formados em rejeitos da mineração de calcário Irati na região de Rio Claro.

\subsubsection{Fósforo}

Assim como o nitrogênio, o fósforo também é um importante elemento que, quando em falta, pode limitar o crescimento da vegetação sobre escombros derivados da atividade de mineração.

Fitter \& Bradshaw (1973), constataram que o fósforo foi deficitário em 5 folhelhos considerados rejeito da mineração de carvão em South Lancashire, Inglaterra.

Roberts et al. (1988 c), apontam o fósforo como o segundo maior elemento limitante em solos de mina devido à rápida fixação em formas não disponiveis.

Roberts et al. (1988 a) citam Plass \& Vogel (1978) apontando o fósforo como sendo o mais limitado nutriente dos solos de mina nos Apalaches (EUA).

$\mathrm{O}$ pH influi na adsorção de fosfato através da modificação das cargas nos materiais de cargas variáveis. Barrow (1984) explica que, quando a superficie é 
positivamente carregada, ocorre um aumento da retenção de fosfato e, quando a superficie é negativamente carregada, há um decréscimo da retenção deste ânion.

$\mathrm{O}$ aumento dos valores de $\mathrm{pH}$ do solo pode acarretar na diminuição da atividade do ferro e do alumínio que poderiam vir a formar precipitados com os íons fosfato. Dessa forma, Lopez-Hernandes \& Burnhan (1974) observaram que o incremento de $\mathrm{pH}$ da solução resultou em um grande decréscimo do $\mathrm{Al}$ trocável e na atividade do alumínio, o que refletiu num decréscimo da retenção do fosfato.

Cho \& Caldwell (1959), encontraram a predominância de fosfatos de ferro e de alumínio em solos ácidos, enquanto que predominava o fosfato de cálcio em solos alcalinos. Porém, em solos com valores de $\mathrm{pH}$ próximos de 7 , essas três formas de fósforo inorgânico se apresentavam quase que igualmente distribuídas.

Valores de $\mathrm{pH}$ superiores a 7 podem provocar um aumento da adsorção do fosfato. De acordo com Roberts et al. (1988) (c) e Monterroso-Martinez (1995), altos valores de $\mathrm{pH}$ e elevados conteúdos de carbonatos nos rejeitos provavelmente reduzem a solubilidade do fósforo nos solos de mina, uma vez que a presença de elementos alcalinos originam compostos de baixa solubilidade com os íons $\mathrm{PO}_{4}^{-3}$.

O fosfato em solução reage com a superficie da calcita e pode apresentar formas cristalinas como as apatitas encontradas por Holford \& Mattingly (1975) em solos desenvolvidos de calcário, ou formar fosfatos dicálcicos e octacálcicos ou ainda precipitados de brushita como encontrados por Freeman \& Rowell (1981) e Wang \& Tzou (1995), respectivamente.

De fato, Cole et al. (1953) já haviam evidenciado que o fosfato em solução é rapidamente sorvido pelo carbonato de cálcio formando precipitados de fosfato dicálcico ou um composto com propriedades similares. Segundo o autor, os produtos iniciais dessa reação são caracterizados pela grande superficie específica e pela maior solubilidade do fósforo em comparação a hidroxiapatita ou fluorapatita.

$\mathrm{O}$ fosfato ainda pode se associar ao $\mathrm{Ca}$ formando complexos que são retidos na superficie da montmorilonita. Esses complexos são solúveis em solução 
fracamente ácida (Ellis \& Troug, 1955). Os autores sugerem que um alto grau de saturação das argilas por Ca irá prevenir a fixação de fósforo pelo ferro ou alumínio.

Hsu \& Jackson (1960), argumentam que os fosfatos de cálcio, de ferro e de alumínio têm solubilidades iguais entre pH 6 e 7, sendo que acima desta faixa o fosfato de cálcio é mais estável que os demais e abaixo desta faixa os fosfatos de ferro e alumínio são mais estáveis que o de cálcio. À valores de $\mathrm{pH}$ inferiores a 7, o fosfato de cálcio pode se dissolver e posteriormente o fosfato pode vir a se precipitar como fosfato de alumínio ou ferro. Os autores concluem que a transformação do fosfato no solo é controlada principalmente pelo $\mathrm{pH}$, mas as taxas de transformação são controladas pela baixa taxa de difusão do ín ao longo dos filmes de umidade que ligam partículas de diferentes espécies.

Em análise de rejeitos com cimentação carbonática e ferruginosa, em área de mineração de carvão no sudeste da Virgínia, Howard et al. (1988), observaram que uma pequena fração do fósforo é associado à óxidos de ferro no material de origem, mas a maioria está associados aos carbonatos. Com o intemperismo e oxidação do material de origem, o fosfato é liberado e pode vir a ser fixado nos óxidos de ferro tornando-se indisponível com o tempo.

A oxidação da pirita (mineral comumente encontrada em associação com carvão e folhelhos pretos) tem como produto o óxido de ferro amorfo que, por sua vez, causa a adsorção do fosfato (Pulfor \& Duncan, 1975).

A rápida oxidação causa um rápido aumento na capacidade de fixação do fósforo em solos jovens (Daniels et al., 1986, citados por Roberts et al., 1988 b), sendo que a fixação desse ânion pode aumentar com o tempo devido à rápida oxidação do ferro e a formação de complexos Fe-P, uma vez que a natureza recente dos rejeitos, aliada à rápida oxidação do ferro, torna o $\mathrm{P}$ especialmente susceptível às reações de adsorção $\mathrm{e}$ fixação (Roberts et al., 1988 a).

Quanto ao mecanismo de fixação do fosfato em óxidos de ferro, Parfitt et al. (1975) indicam que o fosfato forma um complexo de superficie binuclear do tipo $\mathrm{Fe}-\mathrm{O}-\mathrm{PO}_{2}-\mathrm{O}-\mathrm{Fe}$. 
Roberts et al. (1988 c) acrescentam que a diminuição dos níveis de $\mathrm{P}$ também pode estar associada à absorção e fixação deste elemento pelas plantas que o reservam em seus tecidos, podendo não ser desprendido ou mineralizado pelos organismos decompositores.

Apesar da fixação de $\mathrm{P}$ aumentar com o passar do tempo em vários solos de mina (Roberts et al., 1988 a e b e Howard et al., 1988), para Trasar-Cepeda et al. (1993), um aumento de P extraível com a idade do solo de mina pode ser possível devido ao intemperismo do material de origem, além da complexação dos cátions livres pela matéria orgânica. Neste sentido, Soave (1996) encontrou que o aumento da disponibilidade de $\mathrm{P}$ coincide com a idade mais velha (37 anos) dos solos de mina por ela estudados, onde os efeitos da vegetação aceleram o intemperismo dos rejeitos mais eficientemente.

\subsubsection{Cátions trocáveis}

Nos solos de minas, formados a partir dos escombros da atividade mineira e onde não é realizada correções e/ou adubações, a presença e o balanço dos cátions trocáveis, bem como a existência de todos os elementos essenciais à vida das plantas, irá depender sobretudo do material de origem que forma os rejeitos, da forma com que estes rejeitos estão dispostos ou são tratados nos bancos de deposição, do clima que também colabora para a intemperização deste material e lixiviação de elementos, da interações entre os elementos, além é claro, do tempo de exposição deste material às novas condições de superficie.

Não se pode, contudo, deixar de citar a importância da cobertura vegetal nas áreas onde há condições para seu estabelecimento. A vegetação absorve os elementos vitais para sua existência e, após a queda de suas estruturas, contribui para a ciclagem dos nutrientes nestas áreas outrora devastadas. Neste sentido, vários autores já estudaram o comportamento destes elementos em solos de mina.

Anderson (1977) sugere que a lixiviação de sais solúveis é um rápido processo nos estágios iniciais da formação do solo de mina. 
Down (1975 b), estudando o desenvolvimento do solo em relação a idade rejeitos da mineração de carvão, encontrou uma tendência de incremento dos teores de $\mathrm{Ca}$ e $\mathrm{Mg}$ e um ligeiro decréscimo do sódio com o aumento da idade do solo de mina. No entanto, o potássio apresentou um decréscimo inicial, seguido de um aumento gradual de seus teores com a idade do solo.

Schafer et al. (1980) encontraram maior quantidade de sais solúveis de potássio do que de sódio em superficie de solos de mina de carvão formados por mistura de fragmentos de mistura de arenitos e siltitos e solo. Os autores explicam que a predominância de potássio solúvel próximo à superficie indica que os sais acumularam devido à ciclagem de nutrientes que traz o $\mathrm{K}$ à superficie mais rapidamente que o sódio é transportado pela evaporação.

Dentre as bases analisadas por Roberts et al. (1988 a) em solos de mina formados sobre rejeitos compostos de misturas de siltitos e arenitos, no sudeste da Virgínia (USA), o Ca e o $\mathrm{Mg}$ apresentaram decréscimo com o tempo. $\mathrm{O} \mathrm{K}$ apresentou um aumento que os autores atribuíram aos altos conteúdos de mica do material. Havia maiores quantidades de $\mathrm{K}$ extraivel nas camadas superficiais comparado às camadas subsuperficiais, possivelmente devido ao intemperismo biológico da mica e subsequente ciclagem deste nutriente através da absorção pelas plantas e posterior deposição na liteira.

Um alto teor de cimento carbonático e sua taxa de dissolução pode provocar altos níveis de $\mathrm{Ca}$ e $\mathrm{Mg}$ extraíveis em solos muito jovens de mina em comparação aos mais velhos. Nos primeiros anos de estudo sobre os estágios iniciais da pedogênese de um solo de mina sobre rejeitos da mineração de carvão contendo siltitos e arenitos, no sudeste da Virgínia (USA), Roberts et al. (1988 b) encontraram altos valores de $\mathrm{Ca}$ e $\mathrm{Mg}$. Posteriormente seguiu-se um distinto decréscimo destes elementos pois estes cátions e os seus sais foram lixiviados ou incorporados pela vegetação.

Os cátions básicos (principalmente o $\mathrm{Na}$ ) apresentam rápida lixiviação nos solos de mina recentemente formados devido à exposição da superficie do material de rejeito e à formação de longos macroporos após a disturbação (Wood \& Pettry, 1989). 
Com relação ao potássio, os já citados Roberts et al. (1988 b) encontraram maiores valores no tratamento onde usaram serragem como fonte de matéria orgânica na superficie dos rejeitos $\left(4,1\right.$ a 4,9 mmol $_{c} \mathrm{dm}^{-1}$ de $0-5 \mathrm{~cm}$ e 1,6 a $2,3 \mathrm{mmol}_{\mathrm{c}} \mathrm{dm}^{-1}$ de 25 a $30 \mathrm{~cm}$ ), isso ocorreu provavelmente devido à acidificação do meio e a conseqüente liberação de $\mathrm{K}$ proveniente do intemperismo da mica.

Os níveis de potássio encontrados por Hower et al. (1992) em folhelhos betuminosos constituintes do rejeito da mineração de óleo, excedeu os níveis encontrados nos solos nativos e a disponibilidade deste elemento aumentou com a intemperização destas rochas.

Haering et al. (1993), também estudaram solos de mina em formação no sudeste da Virginia (USA), onde foi testado várias misturas de rejeitos da mineração de carvão contendo siltitos e arenitos entre os anos de 1982 à 1987. Os autores relatam que, apesar do $\mathrm{pH}$ e os níveis de $\mathrm{Ca}$ e $\mathrm{Mg}$ extraíveis tenham decrescido em algumas seções, aparentemente devido a lixiviação dos carbonatos expostos, estas propriedades são restauradas posteriormente devido ao intemperismo dos constituintes carbonáticos e conseqüente liberação de $\mathrm{Ca} \mathrm{e} \mathrm{Mg}$, como também devido à fito-ciclagem dos nutrientes. Com relação ao potássio, os autores encontraram maiores concentrações do elemento no ano de 1984, sendo isso atribuído possivelmente aos mais baixos valores de $\mathrm{pH}$ do solo e intemperismo da mica, ou devido a absorção do $\mathrm{K}$ da fertilização inicial pela vegetação $\mathrm{e}$ posterior liberação do elemento durante a decomposição da liteira.

Varela et al. (1993), em estudo sobre a formação do solo em uma área de rejeitos de mineração de linhito na Galicia (Espanha), observaram que os conteúdos Ca e $\mathrm{K}$ apresentaram um claro aumento com a idade do solo de mina, principalmente na camada superficial. Porém os conteúdos de $\mathrm{Na}$ e o $\mathrm{Mg}$ foram muito variáveis, não apresentando relação com a idade do solo.

Em área de mineração de calcário na região de Rio Claro, Soave (1996) também verificou que o calcário e magnésio trocável exibiram uma tenência em diminuir com a idade do solo de mina e o conteúdo de $\mathrm{K}$ foi ligeiramente superior nos perfis mais velhos, o que pode ser devido a retenção do $\mathrm{K}$ na fitomassa nas áreas mais jovens, 
ocorrendo seu retorno ao solo pelo processo de decomposição nas áreas mais velhas onde a ciclagem já deve ter se estabelecido.

No estudo feito por Soave (1996), os valores de Na não apresentaram nenhuma relação à idade dos rejeitos.

O termo "cátions trocáveis", para alguns autores, refere-se à estes cátions como sendo "trocáveis", mas em senso estrito eles realmente refletem os cátions extraíveis, os quais incluem aqueles presos no complexo de troca como aqueles associados com as superficies cortadas ou desgastadas dos grãos de cimento de carbonatos solúveis e dos grãos minerais da matriz e sais solúveis (Roberts et al., 1988 (a e b), Doolittle et al., 1993).

Também Haering et al. (1993) sublinham que os altos valores de $\mathrm{Ca}$ e $\mathrm{Mg}$ por eles obtidos se deve às altas concentrações destes elementos nos carbonatos, como também à tendência do $\mathrm{NH}_{4} \mathrm{OAc}$ em extrair o $\mathrm{Ca}$ e $\mathrm{Mg}$ do cimento carbonático das rochas constituintes do rejeito.

\subsubsection{Ferro livre}

O estudo das formas de ferro livre se faz importante devido a influencia que estes exercem sobre as propriedades dos solos devido sua reatividade, características de carga e levada superficie específica (Quintas-Mosteiro, 1997).

Com o método do oxalato amônico se extrai os compostos de Fe de baixa cristalinidade (considerado como amorfo) e a técnica do ditionito citrato proporciona uma estimativa do Fe livre total que compreende óxidos e hidróxidos bem cristalizados além das formas de baixa cristalinidade e às unidas a matéria orgânica (Holmgren, 1967).

$\mathrm{O}$ ferro pode oxidar de impurezas no complexo carbonato e de agentes ferro-cimentantes encontrados no rejeito reduzido (Roberts et al., 1988 b). Os autores observaram um grande aumento no $\mathrm{Fe}^{+3}$ extraivel nos primeiros anos de experimento por eles conduzido, o que aponta a rápida atuação de processos de intemperização oxidativa naqueles materiais. 
De acorde com Roberts et al. (1988 a), dependendo do grau de lixiviação e oxidação do estrato, o ferro pode se apresentar de várias formas. Os autores notaram que o Fe-ditionito dobrou seus valores de 1982 a 1983, atribuindo esse fato à dissolução do cimento férrico das rochas e à rápida oxidação do ferro, mas observaram um decréscimo do Fe livre em 1984. Para os autores as razões deste decréscimo não são muito claras mas pode estar relacionada à complexação do $\mathrm{Fe}$ com a matéria orgânica. Um rápido aporte de Fe-ditionito, seguido de um declínio pode ser possível presumivelmente devido à complexação do ferro das camadas superficiais com a matéria orgânica (Haering et al., 1993).

Varela et al. (1993), notaram um aumento de ferro livre (extraível em pirofosfato) com o incremento da idade do solo de mina, em área de mineração de linhito na Galicia. De acordo com os autores, o incremento da matéria orgânica coincidiu com o incremento de ferro extraivel por pirofosfato, sugerindo então a formação de complexos organo-minerais e o envolvimento da matéria orgânica nos processos edáficos.

Aumentos de ferro livre com a idade das áreas de rejeitos foram observado por Trasar-Cepeda et al. (1993), também em área de mineração de linhito na Galicia.

\section{4 - Caracterização mineralógica}

O conhecimento da mineralogia dos solos é de fundamental importância para a sua classificação e para a agricultura. Por exemplo, no que se refere à classificação dos solos, um dos parâmetros de distinção de alguns solos com B argiloso é a atividade da argila (alta e baixa). Do ponto de vista agrícola, a argila é a fração que confere ao solo importantes características químicas e de fertilidade, neste sentido Vieira (1988) cita algumas propriedades como a CTC, CTA, retenção de nutrientes como $\mathrm{K}, \mathrm{Ca}, \mathrm{NH}_{4}{ }^{+}$; o efeito das argilas na absorção e inativação de defensivos, etc. No que se refere à fisica dos solos, Mela-Mela (1963) cita que muitas propriedades das argilas se devem primariamente à sua enorme superficie específica, o que implica na absorção de água, adesividade e coesividade. 
A fração areia e silte pode conter minerais intemperizáveis que atuam como uma potencial fonte de nutrientes às plantas. Assim Meurer et al. (1996) evidenciaram que feldspatos e micas na fração areia e silte podem ser fontes potenciais de $\mathrm{K}$.

Vários autores fizeram estudos mineralógicos em solos desenvolvidos em sedimentos da folha de Piracicaba, dentre eles Moniz et al. (1995), ao estudar solos derivados das formações Iratí e Serra Alta, relatam que as esmectitas encontradas como constituinte secundário da fração argila de um podzólico vermelho-escuro, é provavelmente remanescente da rocha sedimentar.

Mais recentemente Calero-Marino (1999) estudou a gênese de solos desenvolvidos sobre a Formação Iratí e encontrou quartzo, plagioclásios e ortoclásio herdados do material de origem. Na fração silte, o autor encontrou basicamente os mesmos minerais da fração areia, porém com o acréscimo da mica e, finalmente, a caulinita, vermiculita, esmectita (provavelmente nontronita) e interestratifidcados representam as argilas silicatadas presentes nos solos por ele estudados. Estes argilominerais também foram relatadas por Telles (1997) em seu estudo sobre a formação de depressões sobre materiais da Formação Irati.

Embora os autores acima citados tenham caracterizado também mineralogicamente os solos naturais desenvolvidos da Formação Irati, os solos recentes em desenvolvimento sobre os rejeitos dessa formação não apresentam nenhum relato referente a sua mineralogia e evolução mineralógica. Soava (1996) estudou a recuperação de uma área de mineração de calcário da Formação Irati na Região de Rio Claro (SP), notando evolução de solos sobre o rejeito da mineração, estudando o material fisica e quimicamente. Apesar da autora não ter caracterizado mineralógicamente estes solos, relata que a fração areia dos mesmos é constituída de lito-relictos proveniente da degradação fisica da rocha, citando betume, elementos piritóides, carbonatos, marmorinas e argilãs.

Kämpf et al., (1997) estudaram a pedogênese em rejeitos com 2 e 5 anos construídos em área de na Bacia Carbonífera do Baixo Jacuí (RS) e notaram que a 
mineralogia dos solo refletiu a composição do material de origem, bem como uma pedogênese incipiente em solos de 5 anos, onde a acidez gerada pela oxidação da pirita provocou uma intemperização acelerada da esmectita e confirmando a caulinita como mineral mais estável. Ainda, segundo os autores, os cristais de pirita presentes nos folhelhos carbonosos e nos fragmentos de carvão incluídos nos perfis se alteram e o produto de sua alteração aparecem como eflorescências pulverulentas esbranquiçadas expostas nas faces de exposição dos perfis, trata-se de várias formas de sulfato de ferro precursoras da jarosita e natrojarosita.

A natrojarosita, formada como produto da oxidação da pirita, também foi evidenciada por Mermut et al. (1985) em solos desenvolvidos sobre folhelhos marinhos do Cretácio.

Por não haver nenhuma menção sobre a mineralogia dos solos desenvolvidos sobre rejeitos de mineração da formação Irati, uma caracterização inicial da mineralogia destes solos recentes é de providencial importância para que se possa fazer futuras comparações e interpretações dos processos de alteração e desenvolvimento destes solos. 


\section{MATERIAL}

\subsection{Localização da área e situação do perfil de extração.}

$\mathrm{A}$ área em estudo encontra-se no município de Saltinho $\left(22^{\circ} 55^{\prime} \mathrm{S}\right.$ e $47^{\circ} 43^{\prime} \mathrm{W}$ ), a $15 \mathrm{~km}$ de Piracicaba - SP (figuras 1 e 2). Trata-se de uma área de exploração de calcário dolomítico pertencente à Formação Irati e comercializado como corretivo de solos. Tal material situa-se a cerca de $21 \mathrm{~m}$ da superficie, sendo necessária a remoção da vegetação, dos horizontes de solo e alterações argilosas e siltosas, além do manto rochoso formado por calcário+silex e folhelhos como ilustra a foto 1 .

A remoção do solo, alterações argilosas e siltosas é feita por um arraste com pá-carregadeira. Já para a retirada do material duro sobrejacente ao calcário é necessário que se faça a detonação da camada rochosa com dinamite e a fragmentação com britadeira mecânica. Posteriormente o material é coletado com pá-carregadeiras e transportado por caminhões de caçamba até os bancos de deposição.

Os rejeitos então são dispostos em montes, ou ainda são depositados em aterros, estes últimos apresentando um acentuado declive. 


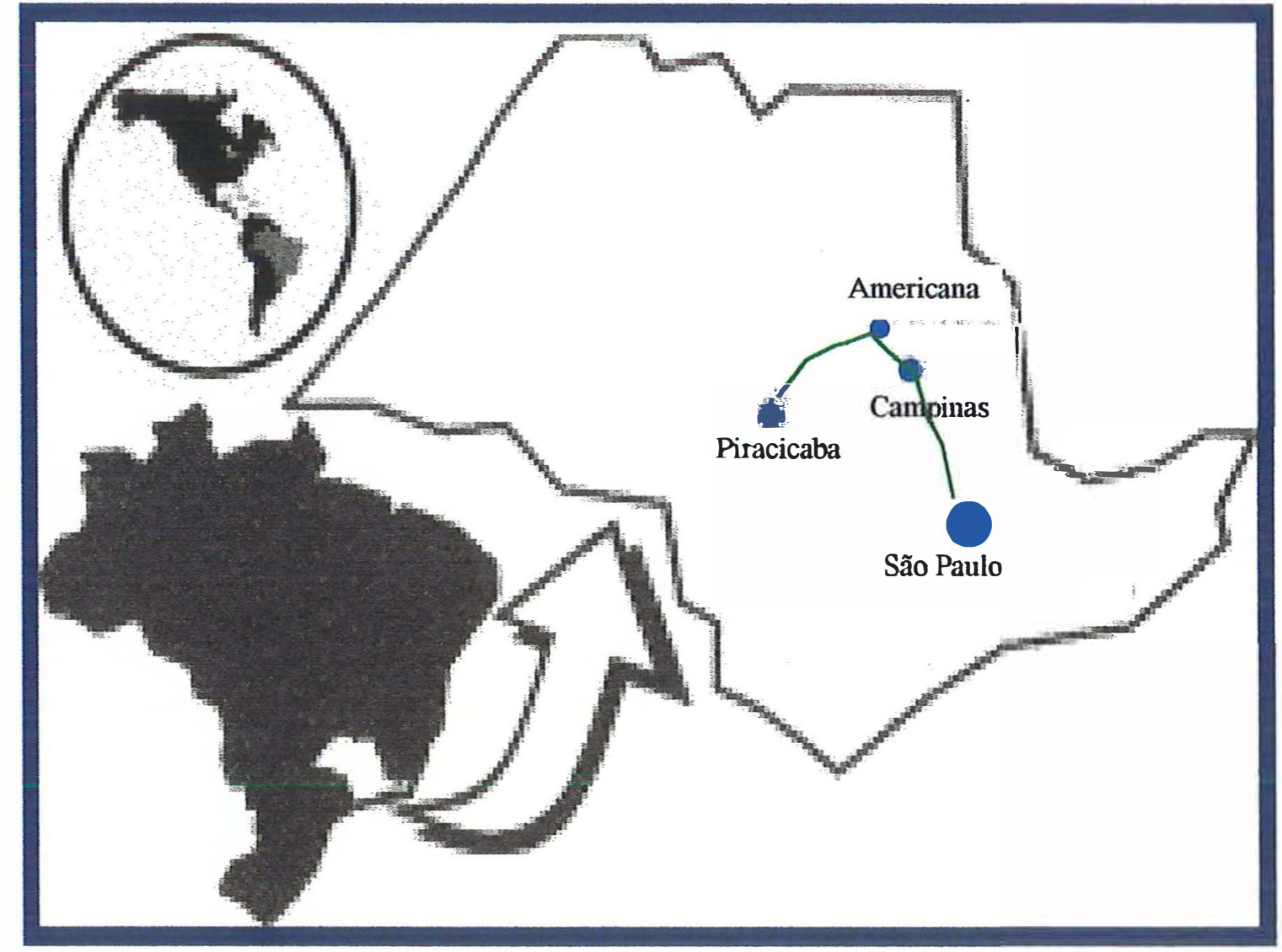

Figura 1- Localização no Estado de São Paulo. 


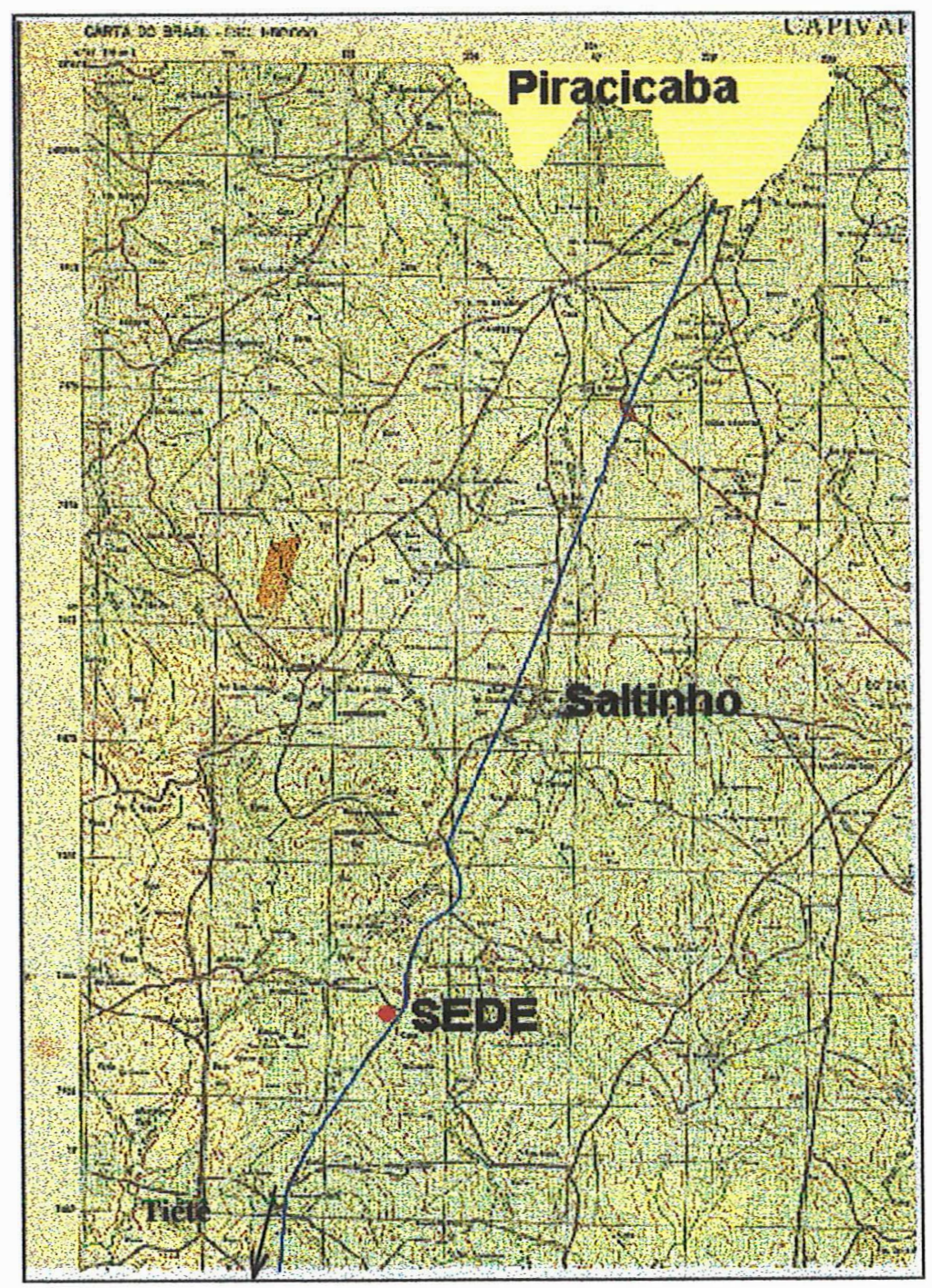

Figura 2- Estrada de acesso à área de mineração (o ponto vermelho representa a sede da empresa). 


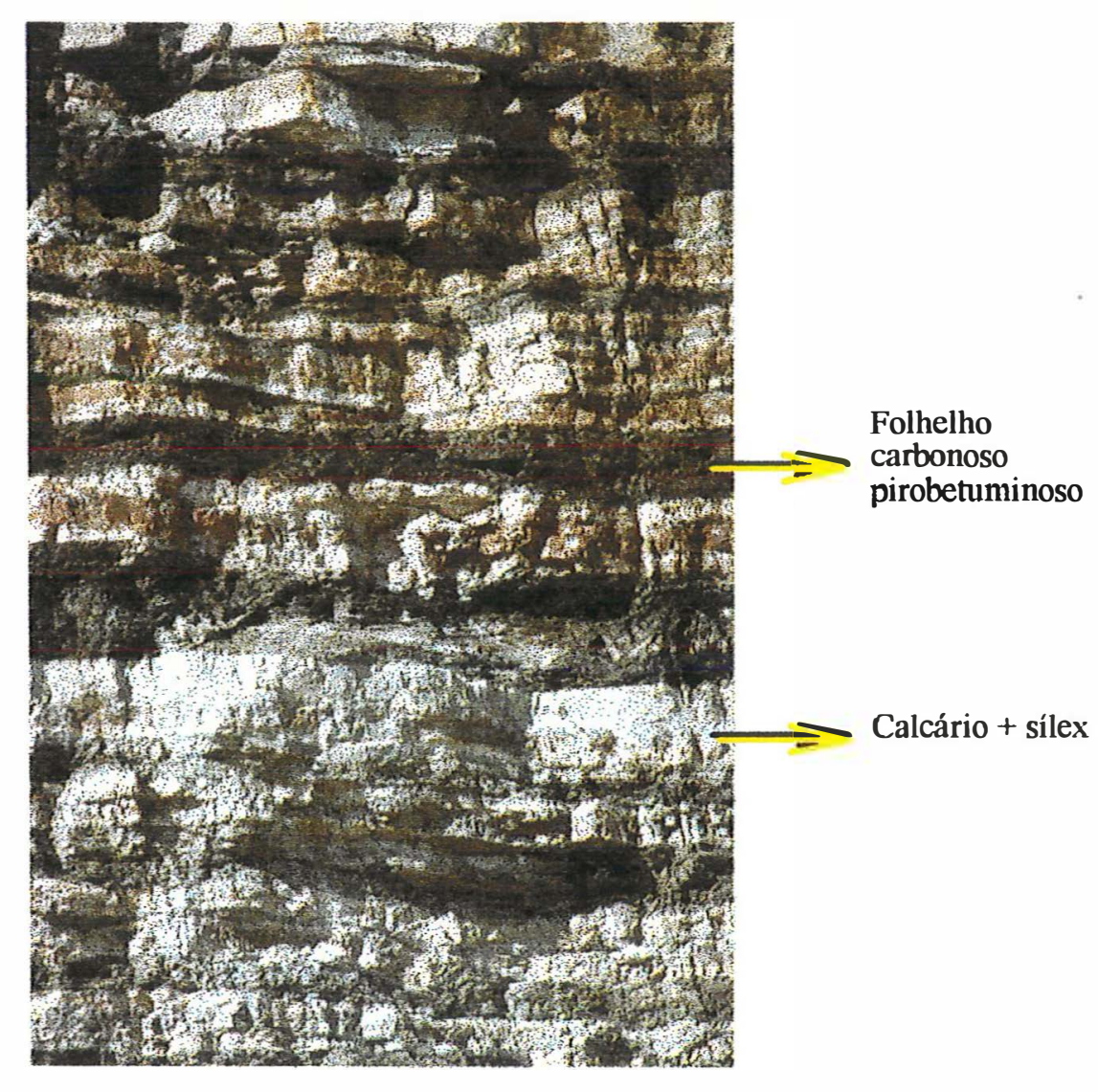

Foto 1 - Calcário com sílex, intercalado com folhelho carbonoso pirobetuminoso disposto na frente de lavra.

\subsection{Caracterização dos Bancos de rejeito}

Devido às diferentes naturezas dos materiais removidos, transportados e aleatoriamente depositados, os bancos de deposição do rejeito apresentam composição variada quanto ao tipo de fragmento de rocha, tamanho dos constituintes, granulometria, textura, estrutura, disposição e grau de alteração dos materiais. No entanto a maioria do material nos bancos de deposição é representada por fragmentos de folhelhos carbonosos e pirobetuminosos e calcário+sílex, ou uma mistura aleatória deste material com alterações argilosas e siltosas e partes do antigo solo, removidas para a realização da exploração do calcário dolomítico. 
Com a cooperação de um antigo funcionário da empresa mineradora foi possível localizar previamente um banco de deposição de rejeito deixado em repouso a partir do ano de 1996 (2 anos); uma segunda área deixada em 1983 (15 anos) e, finalmente uma terceiro banco de rejeitos onde não se faz nenhuma deposição desde 1976 (32 anos). A figura 3 apresenta a disposição destas áreas onde foram abertas as trincheiras P1, P2, P3, P4 e P5.

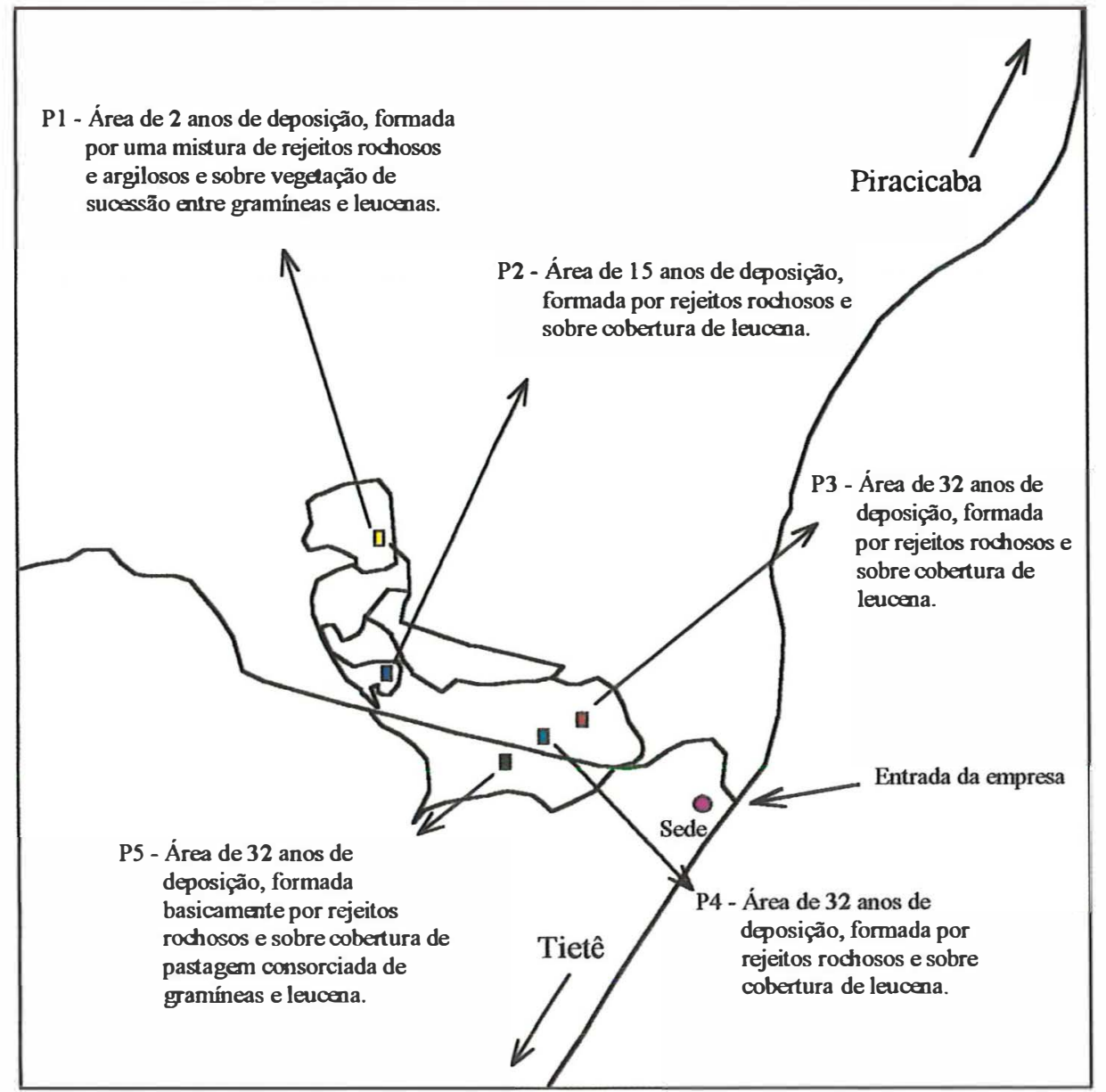

Figura 3- Localização e descrição resumida dos bancos de rejeito onde foram abertos os perfis P1, P2, P3, P4 e P5.

\subsubsection{Descrição morfológicas das trincheiras}

A descrição morfológica das trincheiras foi realizada através de observações feitas em campo por ocasição da abertura das mesmas. Foi feita uma caracterização de cada camada ou horizonte encontrado levando-se em conta 
principalmente a cor, a existência ou falta de estrutura, presença de material fino que se localizava entre os fragmentos rochosos, o estado de alteração das rochas que constituíam o rejeito, presença de eflorescência e a presença e distribuição das raízes nas trincheiras. Na medida do possível, a descrição individualizada dos horizontes ou camadas obedeceu a seguinte ordem: designação do horizonte ou camada; profundidade; cor (em campo foram tomadas as cores dos possíveis horizontes, do material fino que ocupavam os espaços deixados entre os fragmentos rochosos e as cores das rochas e suas alterações predominantes); textura; estrutura (quando presente); consistência seca, úmida e molhada e transição. Segue também observações feitas em campos a respeito da porosidade e da atividade biológica como os aspectos e distribuição de raízes, canais e galerias feitos pela fauna do solo, que as trincheiras apresentavam em sua parede.

A situação dos bancos de deposição dos rejeitos por ocasião do reconhecimento da área, os aspectos genéricos relacionados às rochas, bem como uma visão generalizada dos processos pedogenéticos de cada trincheira é aqui descrito e uma descrição feita aproximada à Lemos \& Santos (1996) se encontra no Anexo Al.

O material mais fino que envolvia os fragmentos rochosos em todos os perfis, servindo de substrato para as plantas e que podia ser correspondente à fração menor que $2 \mathrm{~mm}$, foi considerado aqui como a matriz do solo de mina em formação.

\subsubsection{Banco de rejeitos com 2 anos de deposição}

\section{a) Caracterização da área}

É formada por uma mescla de fragmentos de folhelho, siltitos, argilitos, calcário e material argiloso que pode apresentar estruturação granular pequena a média ou estrutura em blocos pequenos provavelmente herdada do solo preexistente no local de exploração. Estes materiais foram retirados de seu meio natural e depositados ao acaso neste banco de deposição. A vegetação que se formou sobre esse material é constituída de herbáceas representada predominantemente por gramíneas diversas, podendo-se ainda encontrar algumas Asteraceae, Fabaceae, Euphorbiaceae, Amarantaceae e outras. No entanto, pode-se notar a transição para uma vegetação de porte arbustivo devido ao 
progresso de desenvolvimento da leucena que compete com as herbáceas e por atingir um maior porte, acaba sombreando-as, o que está acarretando na morte das mesmas.

Nesta área foi aberta uma trincheira (P1) que foi dividida em 1 camada $\mathrm{L} e$ 3 horizontes ( $\mathrm{A}, \mathrm{Cl}$ e $\mathrm{C} 2)$, conforme observações morfológicas.

\section{b) Aspectos gerais de $\mathbf{P 1}$}

Já com essa idade ( 2 anos) pode-se notar a presença de um horizonte A em formação que possui cor diferenciada e estruturação distinta. Observou-se a intensa atividade biológica na agregação deste material. Os agregados parecem ser formados de material mineral escurecido provavelmente pela matéria orgânica. A porosidade é abundante representada por fissuras entre os agregados, além de canais arredondados pequenos a médios e galerias que atravessam o horizonte $\mathrm{A}$ e chegam até o horizonte $\mathrm{Cl}$, porém esse espaço poral tem uma tendência a diminuir a medida que a profundidade aumenta. As raizes são comuns, predominando as raizes finas típicas de gramíneas e as de leucena que cobriam essa área. Devido o horizonte A se apresentar muito delgado, o material deste horizonte, que seria destinado à posteriores análises, foi cuidadosamente recolhido com uma espátula.

Abaixo do horizonte $\mathrm{A}$, encontra-se os horizontes $\mathrm{C} 1$ adensado e $\mathrm{C} 2$ que aparentemente são formados pelo mesmo material grosseiro e blocos de argilito que podem chegar a $20 \mathrm{~cm}$ se diâmetro. O material rochoso e os blocos de argilito são mesclado à material argiloso menos adensado cuja a estrutura era variada, sendo freqüentes granular média e pequena e em blocos. A presença dessa estrutura, no entanto, é mais evidente em $\mathrm{C} 2$ que em $\mathrm{C} 1$. Este material que envolve os materiais grosseiros e os blocos de argilito foi considerado como a matriz nesta trincheira. A estruturação em blocos mais definida de parte do material encontrado em $\mathrm{C} 1$ e $\mathrm{C} 2$ muito provavelmente não se desenvolveu "in situ", portanto não se deve à pedogênese e provavelmente está relacionada ao empilhamento do rejeito onde $\mathrm{C} 2$ pode ter recebido um material mais estruturado que $\mathrm{Cl}$, conservando desta forma vestígios da estrutura que fora herdada do antigo solo. 
Observa-se ainda que raízes típicas das gramíneas, bem como a atividade da população de minhocas diminuem com o aumento da profundidade. Porém nota-se uma distribuição de raízes mais grossas e tenras comuns em todo o perfil. Essas raízes provavelmente pertencem aos arbustos de leucenas que estão excluindo as gramíneas.

\subsubsection{Banco de rejeitos com 15 anos de deposição.}

\section{a) Caracterização da área}

Aterro formado predominantemente por fragmentos de calcário+sílex e folhelhos carbonosos pirobetuminosos. A cobertura vegetal é formada basicamente por leucena, tendo um porte médio de 3 metros.

Neste banco de deposição foi aberta uma trincheira (P2), onde se encontra material basicamente rochosos. Nota-se fragmentos de calcários de diversas dimensões, desde cascalhos ( 2 a $20 \mathrm{~cm}$ ) até matacões $(<20 \mathrm{~cm}$ ), contudo predomina os folhelhos sobre os calcários. Os folhelhos se fragmentam muito facilmente em placas individuais. $\mathrm{O}$ material mais fino é pouco aderente, sem indício de estrutura visível.

Embora a vegetação apresente um porte relativamente elevado e as raízes apresentam-se abundantes por todo perfil desenvolvendo-se entre as placas de folhelho, nota-se pouco desenvolvimento de solo, sendo mais evidente a presença de um horizonte orgânico. Pode-se observar a formação de cristais aciculares de $\mathrm{CaSO}_{4}$ na superficie dos fragmentos rochosos e até na superficie das raizes. A freqüência e o tamanho destes cristais aumentam com o aumento da profundidade.

Conforme a presença ou ausência de estrutura, abundância de raízes, e presença de $\mathrm{CaSO}_{4}$, esta trincheira é dividida em 1 camada $(\mathrm{L})$ e 3 horizontes $(\mathrm{O}, \mathrm{Cl}$ e C2).

\section{b) Aspectos gerais de $\mathbf{P 2}$}

A liteira é composta de restos vegetais da leucena. Abaixo da liteira formase um horizonte orgânico $(\mathrm{O})$, poroso, constituído de restos vegetais decompostos e pequenos fragmentos de calcário e folhelho em avançado estado de alteração. Sob o 
horizonte $\mathrm{O}$ encontra-se um horizonte $\mathrm{C} 1$ formado por cascalhos de calcário+sílex e principalmente, folhelho que, por se apresentarem em alteração, fragmentam-se facilmente em lâminas pertencentes às frações cascalho e areia. Os fragmentos de folhelho possuem cores variadas entre 2,5YR2,5/0,10R3/1 a 10R2/1 no caso de folhelhos mais escuros e cores vermelho-amareladas e amareladas $10 \mathrm{YR} 3 / 6$ e 2,5Y4/4 em folhelhos mais alterados. Em alguns pontos de $\mathrm{C} 1$ nota-se um material pulverulento e desagregado que se forma principalmente entre os planos de ruptura das placas dos folhelhos. Esse pó possui coloração amarelo-esbranquiçada predominantemente 5Y8/4 a 5Y8/8. Essas manchas amareladas estão por toda a parede do perfil, mas ficam mais comuns a medida a profundidade aumenta na trincheira. $\mathrm{O}$ horizonte $\mathrm{C} 1$ diferencia-se do subjacente $\mathrm{C} 2$ por apresentar menor salinidade em suas paredes e também por possuir maior estabilidade conferida pela presença de raizes finas que se desenvolvem entre as placas de folhelho, formando uma rede. Os matacões estão presentes por todo o perfil e a porosidade é representada principalmente por fissuras entre as lâminas de folhelho e vãos existentes devido ao empilhamento aleatório dos fragmentos rochosos.

Devido a quantidade de cristais de sal aumentar com a profundidade, o horizonte C2 foi dividida em dois sub-horizontes para a coleta das amostras: C2.1correspondente a profundidade 20 a $60 \mathrm{~cm} \mathrm{e} \mathrm{C2.2} \mathrm{referente} \mathrm{a} \mathrm{profundidade} 60$ a $120 \mathrm{~cm}$.

\subsubsection{Banco de rejeitos com 32 anos de deposição}

a) Caracterização da área

Este banco de rejeito é caracterizado pela deposição aleatória de fragmentos rochosos de siltitos, calcários com sílex e folhelhos carbonosos pirobetuminosos. Os calcários apresentam-se desde fragmentos da fração areia até a dimensão de matacões podendo atingir mais de $0,5 \mathrm{~m}$ de diâmetro e são pouco alterados, com alterações predominantemente superficiais, fragmentando-se pouco devido sua natureza maciça.

Os folhelhos mostram um maior grau de intemperização fisica, caracterizada pelo auto grau de fragmentação, e química, percebida por mudanças de 
coloração que indicam a ocorrência de oxidação de ferro. As alterações apresentadas pelos folhelhos são mais avançadas nos horizontes e camadas superficiais. As cores das alterações vão desde avermelhadas $10 \mathrm{R}$ até as mais amareladas $5 \mathrm{Y}$.

Esta área encontra-se toda coberta por uma vegetação de porte arbustivo representada pela Leucena leucocephala que se desenvolve espontaneamente em sua superficie até o ano de 1992, quando a vegetação de parte da área foi cortada e queimada e sua superficie nivelada para a instalação de gramíneas para pastagem. $O$ restante da área permaneceu com a vegetação intacta até 1996 , quando a leucena sofreu um corte e queima, se desenvolvendo novamente, tanto que as plantas se encontravam com o dossel fechado e com uma altura média de $3 \mathrm{~m}$ por ocasião do reconhecimento da área.

Portanto, neste banco com 32 anos foram abertas 3 trincheiras: P3 e P4 sobre a vegetação de leucena e P5 na área de pastagem.

\section{a) Aspectos gerais de P3}

A trincheira apresenta uma camada superficial com cerca de $3 \mathrm{~cm}$ de espessura de liteira $(\mathrm{L})$ constituída por restos vegetais ainda identificáveis derivados da parte aérea das leucenas. Abaixo da liteira nota-se a presença de um horizonte orgânico (O) bem característico por sua coloração enegrecida e sua estruturação fraca, predominantemente granular muito pequena. Esse horizonte é constituído basicamente de material orgânico não identificável, onde se pode perceber alguns pequenos fragmentos de folhelho em estado de alteração na fração areia e poucos cascalhos. Alguns fragmentos de folhelho se desfazem quando esmagados entre o polegar e o indicador, ficando com uma textura siltosa.

Subjacente ao horizonte $\mathrm{O}$, encontra-se um horizonte A constituído por volumes de um material argiloso de coloração bruna. Esses volumes podem variar de tonalidade conforme a presença de canais preenchidos com matéria orgânica ou ainda devido à presença de fragmentos rochosos em estado de alteração. Embora seja possível observar pedoturbações neste horizonte, elas não são muito freqüentes. $\mathrm{O}$ contato entre os horizontes $\mathrm{O}$ e $\mathrm{A}$ apresenta raizes médias e finas dispostas horizontalmente. 
$\mathrm{Na}$ seqüência são distinguidos 3 horizontes denominadas de $\mathrm{C} 1, \mathrm{C} 2$ e C3 que mantém uma característica básica, a rochosidade. $\mathrm{O}$ horizonte $\mathrm{C} 1$ é distinguido dos demais subjacentes por apresentar uma cor mais escura, maior abundância de raízes finas e a ausência de cristais de sal visíveis em sua parede. A partir deste horizonte a rochosidade predomina por todo o perfil. São freqüentes folhelhos em vários estágios de alteração que se fragmentam em placas nas frações areia e cascalho enquanto que os fragmentos do calcário + sílex encontram-se na fração de calhaus e matacões.

Envolvendo os fragmentos de rocha e ocupando os espaços entre estes fragmentos encontra-se um material fino e escuro que une os fragmentos e confere uma aparência maciça à parede do perfil, pode ainda existir alguns pontos isolados no perfil onde se observa alguma estrutura granular. Como em outros perfis já descritos neste trabalho, esse material fino é denominado de matriz por se encontrar entre os fragmentos grosseiros e servir de substrato ao crescimento radicular.

A porosidade é representada por fissuras existentes nos folhelhos e por vãos decorrentes do empilhamento aleatório dos fragmentos rochosos. As raízes são comuns e menos abundantes que em P2, encontrando-se raízes finas, médias e algumas grossas. As raízes finas desenvolvem-se na matriz, em planos de esfoliação dos folhelhos e aderidas à superficie das rochas. Algumas raízes médias e grossas desenvolvem-se tortuosas devido à resistência fisica oferecida pelos fragmentos rochosos.

A eflorescência, devido a grande quantidade de sulfato de cálcio que se forma na superficie das rochas e raízes, aumenta de C2 para C3.

\section{c) Aspectos gerais de P4}

Se encontra nas mesmas condições de $\mathrm{P} 3$, porém o horizonte orgânico preto parece ser mais mesclado com material mineral de coloração bruna ou acinzentada. $\mathrm{O}$ horizonte A desse perfil é menos evidente que aquele encontrado em P3, apresentando em alguns pontos, evidências de atividade biológica como canais e galerias. Observa-se a presença de material individualizado e escurecido no meio da matriz bruna predominante.

Esse material escurecido possui colorações bruno muito escuro 10YR2/2, bruno- 
acinzentado muito escuro 2,5Y3/2 e, com menor freqüência bruno muito escuro 2,5Y3/0. A rochosidade fica evidente a partir de $\mathrm{C} 1$ e tem aspecto semelhante ao da trincheira $\mathrm{P}$. O material fino que envolve os fragmentos grosseiros e os adere é considerado como uma matriz. A partir de $\mathrm{Cl}$ a porosidade é então representada por fissuras inerentes dos fragmentos de folhelho e vãos devidu ao empilhamento aleatório das rochas. As raizes desenvolvem-se por todo o perfil e apresentam um comportamento semelhante ao descrito em P3. As raizes finas se desenvolvem na matriz do rejeito, rente à superficie das rochas e nos planos de ruptura dos folhelhos em alteração. Enquanto que as raízes médias e grossas ocupam os espaços vazios entre os fragmentos rochosos e os contornam procurando caminho entre os calhaus e matacões, podendo, dessa forma, apresentar tortuosidade. Nesta trincheira são considerados uma camada (L) e quatro horizontes $(\mathrm{O}$, $\mathrm{A}, \mathrm{C} 1$ e C2).

\section{d) Aspectos gerais de P5}

Trata-se do mesmo banco de rejeitos no qual foram abertas as trincheiras P3 e P4 anteriormente descritas, porém essa área sofreu o corte e queima da leucena e um aplainamento para posterior semeadura de gramíneas para pastagem. As gramíneas foram semeadas no ano de 1992. Contudo a leucena surgiu espontaneamente entre as gramíneas e seu crescimento é monitorado pelo pastejo do gado e/ou por cortes quando as plantas não são pastejadas para impedir seu crescimento demasiado e o conseqüente abafamento das gramíneas.

Essa área diferencia-se das demais de 32, 15 e 2 anos pois nela nota-se um horizonte A que pode estar compactado (nas trilhas de passagem do gado) ou não (no pé das touceiras). Notou-se também uma população de minhocas e outros organismos em em atividade, principalmente ao redor das touceiras.

A estrutura do horizonte A pode aparecer granular pequena e muito pequena ou em blocos angulares muito pequenos e pequenos fora da trilha do gado. Nas trilhas onde o gado passa a estrutura pode apresentar-se laminar pequena. 
Subjacente ao horizonte A temos uma camada de cascalhos de folhelho em alteração, unidos uns aos outros por um material argiloso. Estes folhelhos ou siltitos fragmentados em lâminas de aproximadamente 3 a $5 \mathrm{~cm}$ não apresentam orientação definida, rompendo-se com facilidade em fragmentos menores sobre certa pressão.A superficie dos planos destes fragmentos possuem cor 2,5Y4/4 e quando os fragmentos são rompidos transversalmente aos planos de fraqueza, apresentam-se bandados milimetricamente com bandas $2,5 \mathrm{Y} 4 / 2$ predominantes.

$\mathrm{O}$ número de calhaus e matacões é reduzido em comparação a $\mathrm{P} 3$ e $\mathrm{P} 4 \mathrm{e}$ representados principalmente por calcários em alteração. Em alguns fragmentos de calcário, cuja a superficie apresenta material siltoso de cores próximas a 5YR5/8 e 10YR6/8, pode-se observar uma rede de raízes finas e tenras crescendo na matriz siltosa e rente à superficie destas rochas.

No horizonte $\mathrm{C} 1$ predomina a falta de estrutura e a aparência maciça, porém pode-se notar algumas galerias de tamanho médio e a formação de agregados granulares em alguns pontos. Abaixo desse horizonte é encontrado um horizonte $\mathrm{C} 2$ aparentemente formado dos mesmos tipos rochosos encontrados em $\mathrm{Cl}$, mas distingue-se deste por apresentar-se mais adensado e argiloso.

Em C2, os cascalhos e calhaus de folhelhos ou siltitos, calcários e sílex em estado de alteração se mesclam à argila que assume cores variando de tons cinza-claro até avermelhados.

Abaixo do horizonte $\mathrm{C} 2$, encontra-se um horizonte rochoso, formado por folhelhos quebradiços e pouco alterados (C3), predominando matacões que se desfazem em placas individuais com a pressão da espátula. Pode-se notar a atuação do intemperismo químico devido a oxidação do ferro nos planos de ruptura dos folhelhos. Os folhelhos podem assumir o tamanho de areia até matacões preservados com tendência ao desfacelamento de suas placas. Há também calhaus e matacões de rocha calcária e pouco material fino entre os fragmentos grosseiros. 


\section{MÉTODOS}

\subsection{Coleta das amostras}

Foram abertas trincheiras nas áreas de rejeito selecionadas, levando-se em consideração a idade da deposição e o tipo de deposição dos rejeitos. Foi realizada uma análise morfológica do perfil e, mediante a presença de horizontes de solo, a análise foi feita conforme Lemos \& Santos (1996). Foram coletadas amostras para a análise de granulometria, análises químicas, mineralógicas e micromorfológicas.

\subsection{Procedimentos analíticos de laboratório}

Assim como em Quintas-Mosteiro (1997), os valores obtidos do conteúdo de materiais grosseiro são orientativos, porém não definem totalmente o grau de pedregosidade das trincheiras estudadas. Em campo, há fragmentos rochosos muito grandes que podem ocupar um grande volume nos bancos de rejeito e representam o material dominante em algumas situações, existindo também, entre estes fragmentos, um material mais fino, no qual as raíses se desenvolviam. Portanto, para as devidas análises, os materiais coletados correspondem àqueles com diâmetro menor que $50 \mathrm{~mm}$ que servia de substrato para o sistema radicular.

\subsubsection{Análise Física}

A granulometria foi determinada por peneiramento (cascalhos e calhaus) e pelo método do densímetro baseado na sedimentação das partículas (areia, silte e argila), conforme Embrapa (1997).

Posteriormente a areia foi fracionada em areia muito grossa, grossa, média fina e muito fina. 


\subsubsection{Análises químicas}

\subsubsection{Análise química para fins de fertilidade}

Após a separação das frações do material, foi separado $0,5 \mathrm{~kg}$ de material de granulometria $<2 \mathrm{~mm}$ (TFSA) para análises de $\mathrm{pH}$ em água, $\mathrm{KCl}$ e $\mathrm{CaCl}_{2}$. O carbono total das rochas e das amostras de solo foi determinado por combustão e o carbono orgânico através do método colorimétrico. $O$ nitrogênio foi determinado por semi-micro Kjeldahal conforme descrito em Malavolta et al. (1997) e o enxofre foi determinado segundo Vitti (1989).

As bases $\left(\mathrm{Ca}^{+2}, \mathrm{Mg}^{+2} \mathrm{e} \mathrm{K}^{+}\right)$foram extraídas por resina trocadora de íons e determinadas por espectrofotometria de absorção atômica $\left(\mathrm{Ca}^{+2} \mathrm{e} \mathrm{Mg}^{+2}\right)$ e por fotometria de emissão $\left(\mathrm{K}^{+}\right) . \mathrm{O} \mathrm{Na}^{+}$foi determinado pelo método Mehlich 1 e o $\mathrm{H}^{+}+\mathrm{Al}^{+3}$ extraído em acetato de cálcio $1 \mathrm{~N}$ a pH 7 e determinado por titulação.

A capacidade de troca cationica (CTC) foi determinada pelo método direto, saturando-se a amostra com acetato de cálcio e posteriormente quantificando-se o $\mathrm{Ca}^{+2}$ retido e extraído do complexo de troca. A porcentagem de saturação por bases (V\%) foi calcılada a partir da razão da soma de bases (S) pela CTC e multiplicando-se por 100 .

Os micronutrientes $\mathrm{Cu}, \mathrm{Fe}, \mathrm{Mn}$ e $\mathrm{Zn}$ foram extraídos com DTPA e determinados por espectrofotometria. O boro foi analisado usando-se solução de cloreto de bário, de acordo com Abreu \& Abreu (1996).

\subsubsection{Ferro livre (amorfo e cristalino)}

O ferro foi extraído com ditionito-citrato-bicarbonato (DCB) e oxalato de amônio conforme descrito em Camargo et al. (1986).

O ferro cristalino foi estimado pela diferença do Fe (ditionito) $\mathrm{Fe}$ (oxalato). 


\subsubsection{Ataque sulfúrico e determinação dos índices de intemperísmo}

Ki e Kr.

A $\mathrm{SiO}_{2}$ foi extraída a partir do ataque alcalino a quente e o $\mathrm{Al}_{2} \mathrm{O}_{3}, \mathrm{TiO}_{2}$, $\mathrm{Fe}_{2} \mathrm{O}_{3}$ e $\mathrm{MnO}$ foram obtidos através de ataque sulfúrico a quente (conforme descrito em Camargo et al., 1986). A determinação da $\mathrm{SiO}_{2}$ foi feita por gravimetria, $\mathrm{Al}_{2} \mathrm{O}_{3}$ por titulação, $\mathrm{TiO}_{2}$ por colorimetria e $\mathrm{Fe}_{2} \mathrm{O}_{3}$ e $\mathrm{MnO}$ por espectrofotometria de absorção atômica.

$\mathrm{O} \mathrm{Ki}$ foi calculado pela relação molecular entre a \% de $\mathrm{SiO}_{2}$ e $\mathrm{Al}_{2} \mathrm{O}_{3}$ e o $\mathrm{Kr}$ segundo a relação molecular entre $\mathrm{SiO}_{2}$ e $\left(\mathrm{Fe}_{2} \mathrm{O}_{3}+\mathrm{Al}_{2} \mathrm{O}_{3}\right)$

\subsection{Análises mineralógicas}

\subsubsection{Preparo das amostras}

As amostras dos solos e das rochas sãs sofreram um tratamento prévio para a eliminação dos sais solúveis, ferro e matéria orgânica. Inicialmente removeu-se os sais solúveis usando-se uma solução de acetato de sódio a $\mathrm{pH} 5$ e posteriormente foi feita a oxidação da matéria orgânica com peróxido de hidrogênio a 30 \% e remoção do ferro com citrato de sódio $0,3 \mathrm{M}$, bicarbonato de sódio $1 \mathrm{M}$, ditionito de sódio. Finalmente a fração areia foi separada por peneiramento e a silte + argila foi separada por sifonação.

\subsubsection{Microscopia petrográfica}

Após o tratamento, a fração areia muito fina destes solos foi analisada em microscópio petrográfico.

\subsubsection{Difratometria de raios- $X$}

A fração silte e argila foram analisadas por difratometria de raios- $X$ de acordo com Jackson (1956). Utilizou-se um difratômetro Rigaku com tubo de Cobre (K $\alpha$ de $1,5418 \AA$ ) com filtro de níquel. 
A fração argila foi saturada com $\mathrm{K}^{+}$e $\mathrm{Mg}^{+2}$ e após o processo de saturação, confeccionou-se lâminas orientadas que, posteriormente, foram submetidas a irradiação com raios-X no intervalo $2 \theta$ de $3^{\circ}$ a $30^{\circ}$.

Sub-amostras de argilas saturadas com $\mathrm{Mg}^{+2}$ foram solvatadas com etileno-glicol e outras sub-amostras de argilas saturadas com $\mathrm{K}^{+}$foram submetidas a aquecimentos de $350^{\circ}$ e $550^{\circ}$. Posteriormente estas amostras foram irradiadas para a verificação de possiveis alterações em suas distâncias basais.

A fração silte, após sifonação, foi exposta em lâminas que também foram submetidas à irradiação por de raios-X.

Após realizados os difratogramas os picos dos minerais foram identificados de acordo com Griffin (1971) e Jackson (1969).

\subsubsection{Análise micrográfica}

Uma análise micrográfica dos horizontes superficiais foi feita para retratar os minerais presentes nos solos de mina em estudo que não foram detectados pela difratometria de raios-X.

\subsection{Análises micromorfológicas}

O presente estudo não teve o objetivo de classificar micromorfológicamente os horizontes formados e sim, evidenciar as primeiras etapas de formação dos horizontes de superficie destes recentes solos de mina. Foram coletadas amostras indeformadas dos horizontes minerais superficiais. Estas amostras, após o secamento ao ar, foram impregnadas à vácuo com resina ortoftálica diluída em monômero de estileno e secas ao ar. Posteriormente, após estarem totalmente secas, foi realizado o corte para observações do estado da estrutura em lupa binocular e confecção de lâminas delgadas para observações em microscópio petrográfico. 


\section{RESULTADOS E DISCUSSÃO}

Devido aos métodos de retirada, transporte e estocagem do material considerado como rejeito a partir da frente de lavra, pode-se haver mistura de materiais bem diferentes. É o caso do perfil P1 que apresenta terra e blocos de argilito ocupando um volume considerável no perfil. Em outras situações, os perfis possuem material moderadamente uniforme como é o caso dos perfis P2, P3, P4 e P5 abertos em bancos formados pelos rejeitos de calcário + sílex e folhelhos carbonosos pirobetuminosos. A foto 2 ilustra o aspecto geral em que se encontram os perfis P1 (2 anos), P2(15 anos), P3, P4 e P5 (32 anos).

Apesar da heterogenidade do material depositado nos bancos de rejeitos, pode-se observar tendências que indicam a situação atual de desenvolvimento destes solos de mina e, através disso, caracterizar os processos de pedogênese atuantes nos bancos de rejeito.

A foto 2 ilustra o aspécto geral em que se encontram os perfis $\mathrm{P} 1$ ( 2 anos), P2 (15 anos), P3, P4 e P5 (32 anos).

\subsection{Caracterização dos perfis e formação do solo sobre os rejeitos de mina}

Para a separação morfológica dos horizontes destes solos de mina, alguns aspectos foram levados em consideração tais como, cor, textura, grau de estrutura, presença e distribuição de raizes e eflorescência. Para melhor interpretação dos dados e facilitar as comparações entre os diferentes horizontes e perfis, os principais aspectos morfológicos foram sintetizados na tabela 1 . 


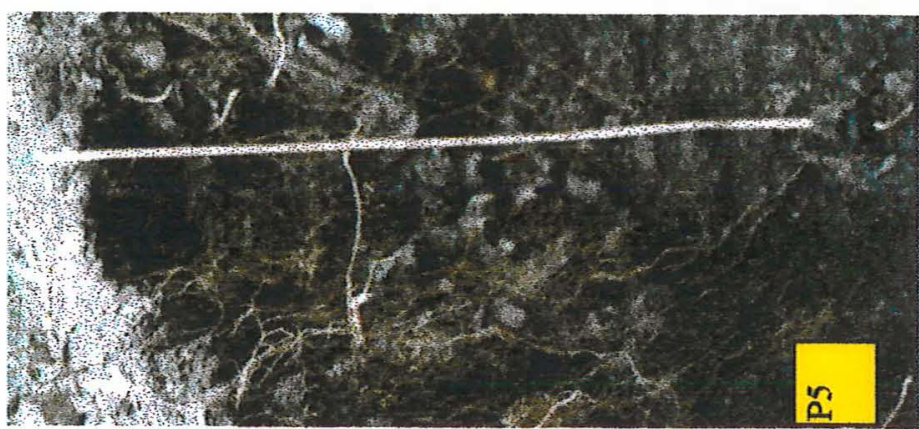

음
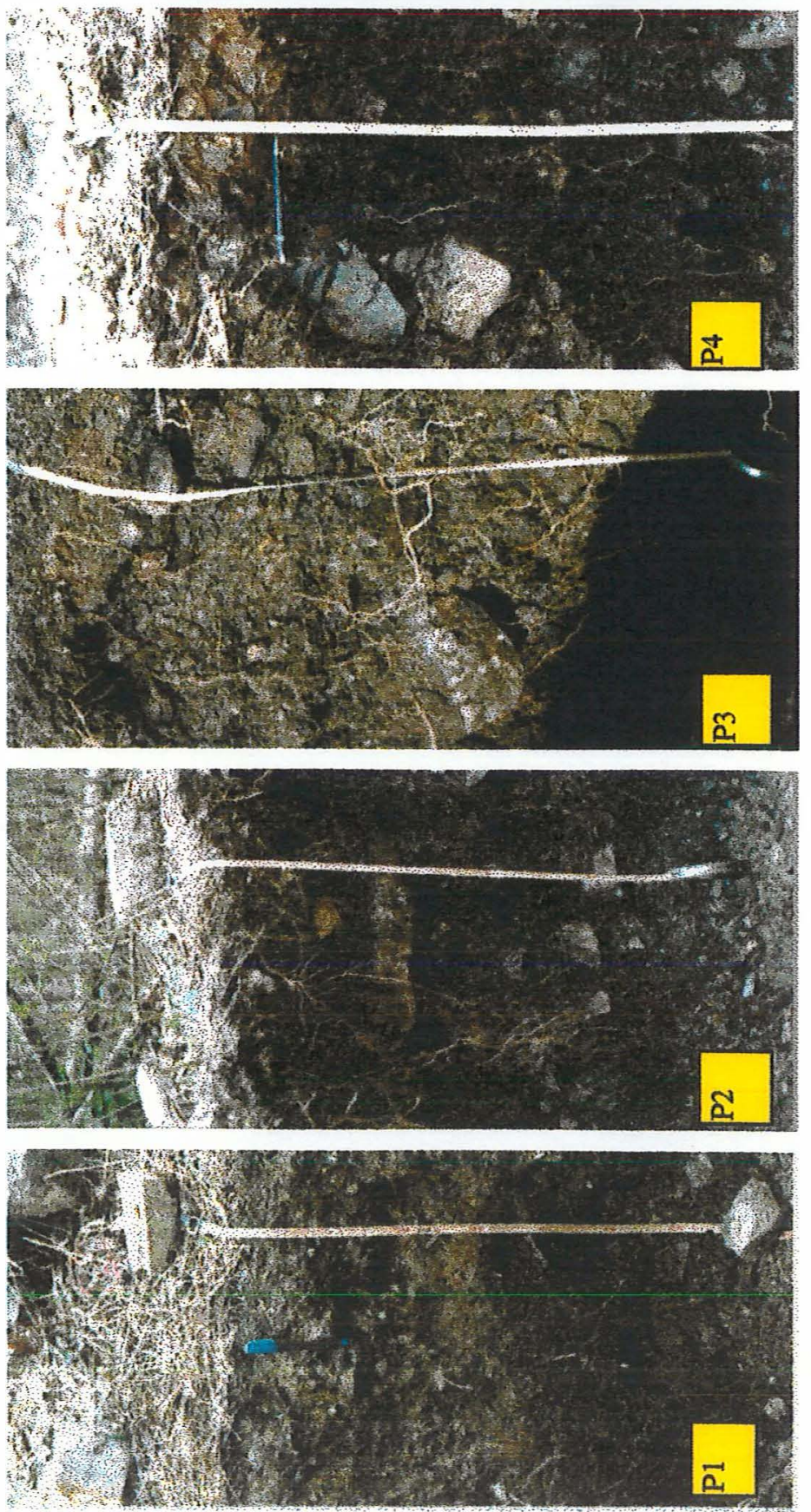
Tabela 1- Resumo das características morfológicas dos solos em formação sobre rejeitos da mineração do calcário da Formação Irati.

\begin{tabular}{|c|c|c|c|c|}
\hline Perfil & horizonte & prof. (cm) & $\begin{array}{c}\text { Cores } \\
\text { predominantes }\end{array}$ & textura/estrutura \\
\hline \multirow[b]{3}{*}{ (2 anos) } & $\mathrm{A}$ & $0-3$ & $2,5 Y 3 / 0$ e $3 / 2$ & \multirow{3}{*}{$\begin{array}{l}\text { muito argilosa com cascalhos/ fraca a } \\
\text { moderada, pequena e muito pequena granular. } \\
\text { argila muito cascalhenta, com calhaus e } \\
\text { matacões/ maciça e forte em blocos angulares } \\
\text { pequenos e fraca granular média e pequena. } \\
\text { argila muito cascalhenta com calhaus e } \\
\text { matacões/ moderada granular média e pequena; } \\
\text { forte, muito pequena e pequena a média em blocos } \\
\text { angulares. }\end{array}$} \\
\hline & $\mathrm{Cl}$ & $3-30$ & $\begin{array}{c}\text { 10YR4/4, } \\
2,5 Y 4 / 4 \text { e } 5 / 4\end{array}$ & \\
\hline & $\mathrm{C} 2$ & $30-80$ & $\begin{array}{c}10 Y R 4 / 3 \\
2,5 Y 5 / 4 \text { e } 4 / 4\end{array}$ & \\
\hline \multirow[b]{3}{*}{ (15 anos) } & $\mathrm{O}$ & $3-0$ & $10 \mathrm{YR} 3 / 2$ e $2 / 2$ & \multirow{3}{*}{$\begin{array}{l}\text { argilo-arenosa cascalhental fraca, muito } \\
\text { pequena granular. } \\
\text { areno-argilosa muito cascalhenta com calhaus e } \\
\text { matacões/sem estrutura, rompendo-se em } \\
\text { fragmentos laminatres individuais. } \\
\text { arenosa muito cascalhenta com calhaus e } \\
\text { matacões/sem estrutura, rompendo-se em } \\
\text { fragmentos individuais. }\end{array}$} \\
\hline & $\mathrm{Cl}$ & $0-20$ & $2,5 Y 3 / 2$ & \\
\hline & $\mathrm{C} 2$ & $20-100$ & $2,5 Y 4 / 2$ e $5 / 2$ & \\
\hline \multirow{7}{*}{ (32 anos) } & $\mathrm{O}$ & $3-0$ & 10YR2/1 & \multirow{7}{*}{$\begin{array}{l}\text { areno-argilosa cascalhenta/ fraca, muito } \\
\text { pequena, granular. } \\
\text { argila cascalhenta/ moderada, pequena a muito } \\
\text { pequena granular e moderada muito pequena em } \\
\text { blocos angulares. } \\
\text { argilo-arenosa muito cascalhenta com calhaus e } \\
\text { matacões/ sem estrutura, rompendo-se em } \\
\text { fragmentos laminares individuais. } \\
\text { areno-argilosa muito cascalhenta com calhaus e } \\
\text { matacões/ sem estrutura, rompendo-se em } \\
\text { fragmentos laminares individuais. } \\
\text { arenosa muito cascalhenta com calhaus e } \\
\text { matacões/ sem estrutura, rompendo-se em } \\
\text { fragmentos laminares individuais. }\end{array}$} \\
\hline & A & $0-3$ & 7,5YR3/4 e 5YR4/6 & \\
\hline & $\mathrm{Cl}$ & $3-20$ & $2,5 Y 2 / 0$ e $2,5 Y 3 / 0$ & \\
\hline & & & & \\
\hline & $\mathrm{C} 2$ & $20-80$ & $10 Y R 3 / 2,2,5 Y 3 / 1$ e & \\
\hline & & & $3 / 2$ & \\
\hline & $\mathrm{C} 3$ & $80-120$ & $\begin{array}{c}10 Y R 3 / 3,2,5 Y 4 / 4 \text { e } \\
3 / 2\end{array}$ & \\
\hline \multirow{4}{*}{ (32 anos) } & $\mathrm{O}$ & $3-0$ & $\begin{array}{c}2,5 Y 2 / 0,10 Y R 4 / 4, \\
4 / 3,4 / 2 \text { e } 3 / 2\end{array}$ & \multirow{4}{*}{$\begin{array}{l}\text { areno-argilosa cascalhenta/ fraca a moderada } \\
\text { muito pequena granular. } \\
\text { argila cascalhenta/ moderada pequena e muito } \\
\text { pequena granular e moderada muito pequena em } \\
\text { blocos angulares. } \\
\text { rgilo-arenosa muito cascalhenta com calhaus e } \\
\text { matacões/ sem estrutura, rompendo-se em } \\
\text { fragmentos laminares individuais. } \\
\text { areno-argilosa muito cascalhenta, com calhaus } \\
\text { e matacões/ sem estrutura, rompendo-se em } \\
\text { fragmentos laminares individuais. }\end{array}$} \\
\hline & A & $0-3$ & $\begin{array}{l}\text { 10YR } 4 / 4,3 / 4 \\
4 / 3 \mathrm{e} 4 / 2\end{array}$ & \\
\hline & $\mathrm{Cl}$ & $3-30$ & $10 \mathrm{YR} 3 / 2$ e $3 / 3$ & \\
\hline & $\mathrm{C} 2$ & $30-70$ & $10 Y R 4 / 1$ e $3 / 2$ & \\
\hline \multirow{4}{*}{ (32 anos) } & $\mathrm{A}$ & $0-4$ & $\begin{array}{c}10 Y R 3 / 3,3 / 4,2 / 2 \mathrm{e} \\
5 / 4\end{array}$ & \multirow{3}{*}{$\begin{array}{l}\text { argilo-arenosa cascalhental moderada muito } \\
\text { pequena a pequena granular, moderada muito } \\
\text { pequena em blocos e laminar. } \\
\text { areno-argilosa muito cascalhental sem } \\
\text { estrutura, ronpendo-se em fragmentos laminares } \\
\text { individuais a maciço. } \\
\text { argilosa muito cascalhenta/ maciço. }\end{array}$} \\
\hline & $\mathrm{Cl}$ & $4-50$ & 2,5Y5/4, & \\
\hline & $\mathrm{C} 2$ & $50-70$ & $\begin{array}{l}\text { 2,YYR4/8 e } 4 / 6 \\
10 Y R 6 / 6,2.5 Y 6 / 8\end{array}$ & \\
\hline & C3 & $70-100$ & $\begin{array}{l}2,5 Y R 3 / 4 \text { e } 3 / 2 \\
2,5 Y 6 / 6 \text { e } 8 / 6\end{array}$ & $\begin{array}{l}\text { arenosa muito cascalhenta/ sem estrutura, } \\
\text { rompendo-se em placas laminares individuais. }\end{array}$ \\
\hline
\end{tabular}


Devido à variação de cores encontrada dentro de uma mesma camada ou horizonte nos perfis, adotou-se as cores mais representativas dos horizontes ou camadas. Segue-se então uma discussão dos dados morfológicos com ênfase nos horizontes superficiais, onde foram realizadas observações mais detalhadas de sua micromorfologia.

\subsubsection{Trincheira P1 no banco de 2 anos}

O banco de rejeitos é formado por fragmentos rochosos de siltitos, folhelhos e calcários de vários tamanhos, desde cascalhos até alguns poucos matacões. Esse material grosseiro é ainda misturado à blocos de argilito e à material mais fino, semelhante a terra.

Esta área se encontra coberta por gramíneas que estão sendo excluídas pelo avanço de crescimento da leucena.

Com base em dados morfológicos e observações de microfotografias é possível observar a atuação da pedogênese na superficie dessa trincheira. Observou-se um horizonte A em formação com cerca de $3 \mathrm{~cm}$ de espessura que se distingue dos horizontes subjacentes por apresentar coloração escurecida, devido ao acúmulo de matéria orgânica na superficie, estruturação pequena granular mais definida e contínua e maior porosidade.

As microfotografias deste horizonte revelam um acúmulo relativo do esqueleto constituído de pequenos fragmentos rochosos nos primeiros milímetros superficiais, que provavelmente se deve à perda de plasma devido à pouca estabilidade do material recentemente exposto às novas condições superficiais (foto $3 \mathrm{~A}$ ).

Neste horizonte predomina uma porosidade fissural decorrente das contrações de argilas expansivas e do intemperismo fisico evidenciado pela fragmentação de rochas pouco consolidadas (foto $3 \mathrm{~B}$ ) como argilitos e siltitos e também à esfoliação dos folhelhos. Próximo à superficie, o intemperismo fisico e possivelmente o químico promove, respectivamente, quebra e dissolução dos fragmentos maiores de rocha em fragmentos pertencentes à fração TFSA $(<2 \mathrm{~mm})$ (Ciolkosz et al., 1985). A porosidade 
fissural que se desenvolve, aliada à canais radiculares (foto $3 \mathrm{C}$ ) e galerias (foto $3 \mathrm{D}$ ) constituem uma porosidade contínua. O desenvolvimento da porosidade acaba individualizando agregados argilosos e cascalhos pouco consolidados, conferindo uma estrutura granular fraca.

Almeida (1983), estudando a formação de solos em rejeitos de calcário, também observou a presença de um horizonte AC de 3 e $10 \mathrm{~cm}$ de espessura em perfis com 2,5 e 5 anos de idade, respectivamente, concluindo que houve predomínio do intemperismo físico-químico com irrelevância do biológico, em função da vegetação e conseqüente redução da atividade dos microorganismos.

Abaixo do horizonte A, a estrutura encontrada no material que envolve os fragmentos grosseiros e os blocos de argilito, bem como a estrutura forte em blocos encontrada em volumes distintos em ambos horizontes $\mathrm{C} 1$ e $\mathrm{C} 2$, não podem ser relacionadas à pedogênese, já que se trata de um banco de apenas dois anos de repouso. Nestes horizontes, não é possível observar uma continuidade no tipo de estrutura, sendo esta frequentemente interrompida por blocos de argilito e por fragmentos rochosos.

Alguns volumes dentro dos horizontes $\mathrm{C} 1$ e $\mathrm{C} 2$ são constituídos de macroagregados arredondados de tamanho variável que, quando rompidos, podem apresentar alguma estrutura granular ou em blocos. Mcsweeny \& Jansen (1984) denominam de "fritted" para descrever uma estrutura artificial particular de solos construídos. Portanto, eventualmente presentes nos horizontes $\mathrm{C} 1$ e $\mathrm{C} 2$, estas estruturas devem ser encaradas como relíquias herdadas do antigo solo que foi removido, transportado e depositado neste monte, juntamente com os fragmentos mais grosseiros e blocos de argilito.

$\mathrm{O}$ fato de que o horizonte C2 (mais profundo) possuir uma estrutura mais evidente que $\mathrm{Cl}$ pode ser possível devido ao empilhamento do material. Pode ter ocorrido a deposição de material de uma camada pedogeneticamente menos evoluída sobre uma mais evoluída, uma vez que a estratificação de camadas contrastantes são comuns em solos de mina (Schafer et al., 1980) e o maior adensamento de C1 em relação a C2 pode ser devido ao tráfego do equipamento usado na construção do solo de mina (Kämpf et al., 1997). 


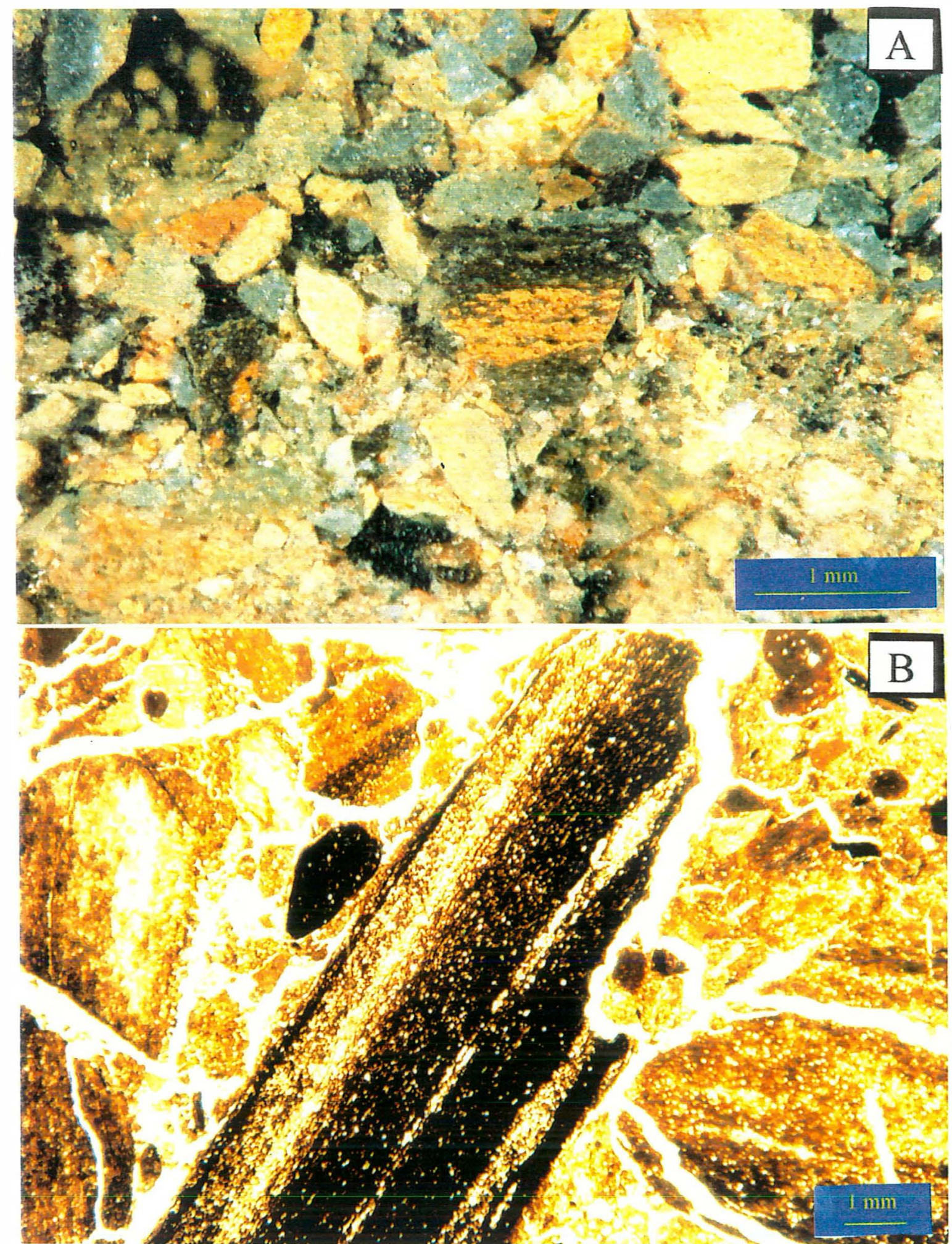

Foto 3 - Estrutura do horizonte A de Pl (2 anos). A: notar acumulação de esqucleto nos primeiros milímetros superficiais $(+25 \mathrm{x})$; B: Porosidade fissural $(+10 \mathrm{x})$ decorrente da contração das argilas e fragmentação das rochas pouco consolidadas. 

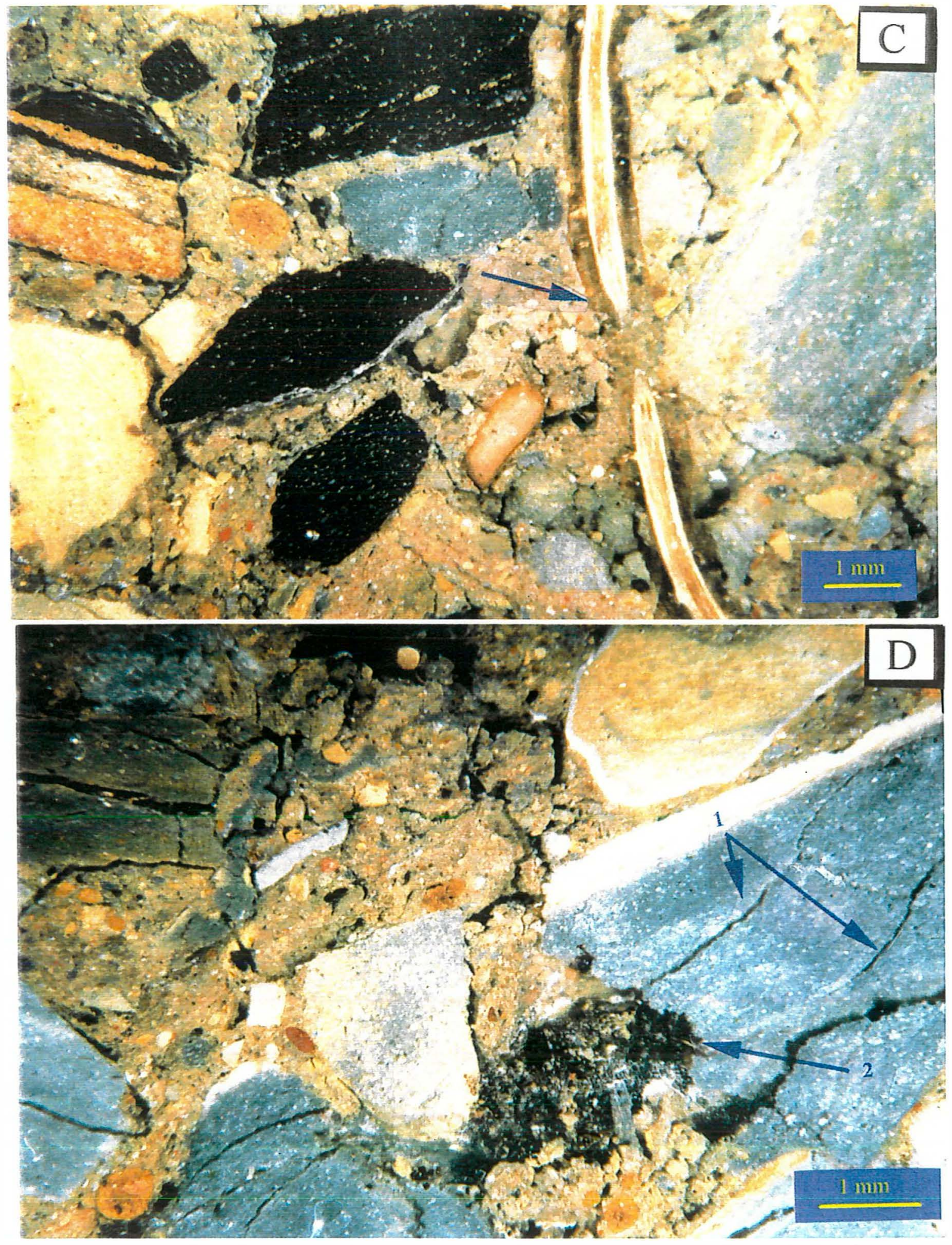

Foto 3 (continuação) - C: Estrutura fraca granular (+12x), notar (1) fissuras (2) canal radicular; D: (1) Intemperismo fisico do folhelho, (2) galeria preenchida com material orgânico $(+16 \mathrm{x})$. 


\subsubsection{Trincheira $\mathbf{P 2}$ no banco de 15 anos}

O banco de rejeitos onde foi aberta a trincheira P2 possui 15 anos e é formado basicamente por fragmentos de calcário com sílex e folhelhos pirobetuminosos. Esta trincheira apresenta uma liteira constituída de restos vegetais da leucena que podem ser ainda identificáveis. Abaixo da liteira encontra-se um horizonte orgânico $O$ de $3 \mathrm{~cm}$ de espessura, bem distinto pela cor escurecida bruno-acinzentado muito escuro (10YR3/2, matriz úmido) e bruno muito escuro (10YR2/2, matriz úmido); e pela presença de uma fraca estrutura granular muito pequena.

Não é possível notar a presença de um horizonte A propriamente dito neste perfil pois, não se detecta nada que possa caracterizar o desenvolvimento de estrutura abaixo do horizonte orgânico.

As microfotografias da transição dos horizontes $\mathrm{O} / \mathrm{Cl}$ revelam que ocorre uma total perda do plasma e materiais finos, restando o esqueleto cascalhento que se intercala com pelotas fecais conferindo a este horizonte uma abundante porosidade, representada pelos espaços vazios existentes entre os fragmentos rochosos e pelotas orgânicas (foto 4 A).

Materiais finos provenientes do horizonte $\mathrm{O}$ acumulam-se posteriormente no horizonte $\mathrm{C} 1$. Este horizonte é composto por fragmentos de folhelhos em alteração, misturado a materiais mais resistentes como fragmentos de calcário e sílex e possui cor bruno-acinzentado muito escuro (2,5Y3/2, matriz úmida). A foto $4 \mathrm{~B}$ retrata os fragmentos rochosos de folhelhos e calcários que se depositaram aleatoriamente.

A partir deste horizonte o perfil apresenta-se bastante rochoso, predominando calhaus e matacões.

A ação do sistema radicular da leucena no intemperismo biológico é evidenciada em fragmentos rochosos do horizonte $\mathrm{C} 1$ do perfil P2 (14 anos). As raízes desenvolvem-se abundantemente entre as placas soltas dos folhelhos em alteração, colaborando para sua fragmentação e, dessa forma, acelerando o processo de pedogênese (foto $5 \mathrm{~A}$ ). 
Se, por um lado, Almeida (1983) constatou irrelevancia do intemperismo biológico na formação de um horizonte $\mathrm{AC}$ em rejeitos da mineração de calcário com 2,5 e 5 anos, Soave (1996) relata que o intemperismo fisico químico se mostra intenso devido a ação biológica ocasionando uma maior agregação da estrutura no horizonte Ap de uma área de mineração de calcário de 9 anos.

Abaixo de $\mathrm{C} 1$ encontra-se o horizonte $\mathrm{C} 2$ constituído pelo mesmo material sobrejacente, se distinguindo, no entanto, por apresentar cristais aciculares de sulfato de cálcio na superficie das rochas e raízes (foto $5 \mathrm{~B}$ ). Estes cristais aumentam de tamanho e quantidade a medida em que se avança a profundidade. Os cristais de gesso são comuns em rejeitos onde acidez gerada pela oxidação da pirita é neutralizada pela dissolução dos carbonatos, podendo precipitar ao longo dos canais condutivos, como constatado por Doolitle et al., (1993).

A partir de $\mathrm{Cl}$ também se nota locais de coloração amarelo-claroacinzentado (2,5Y8/4) a amarelo (5Y8/6) referentes às eflorescências pulverulentas que geralmente observadas nas superficies de alguns folhelhos em alteração (foto $5 \mathrm{C}$ ). A difratometria de raios- $\mathrm{X}$ deste material indica a presença de natrojarosita (figura $64 \mathrm{da}$ página 112), produto da oxidação da pirita (Mermut et al., 1985), que se forma devido à migração de soluções com íons de $\mathrm{SO}_{4}^{-2} \mathrm{e} \mathrm{Fe}^{+2}$ (Kämpf et al., 1997).

As cores predominantes no material mais fino em C2 são o brunoacinzentado escuro (2,5Y4/2, úmido) e buno-acinzentado (2,5Y5/2, úmido). As raízes são bem distribuídas, porém menos freqüentes que as presentes no horizonte sobrejacente (C1). Há um maior número de raízes médias e estas frequentemente se apresentam tortuosas por se desviarem dos fragmentos mais grosseiros.

Fazendo uma comparação das cores predominantes neste perfil, nota-se que os valores dos horizontes $\mathrm{O}$ e $\mathrm{Cl}$ são baixos, indicando maior quantidade de preto, o que pode indicar uma maior influência da matéria orgânica em relação a C2. 


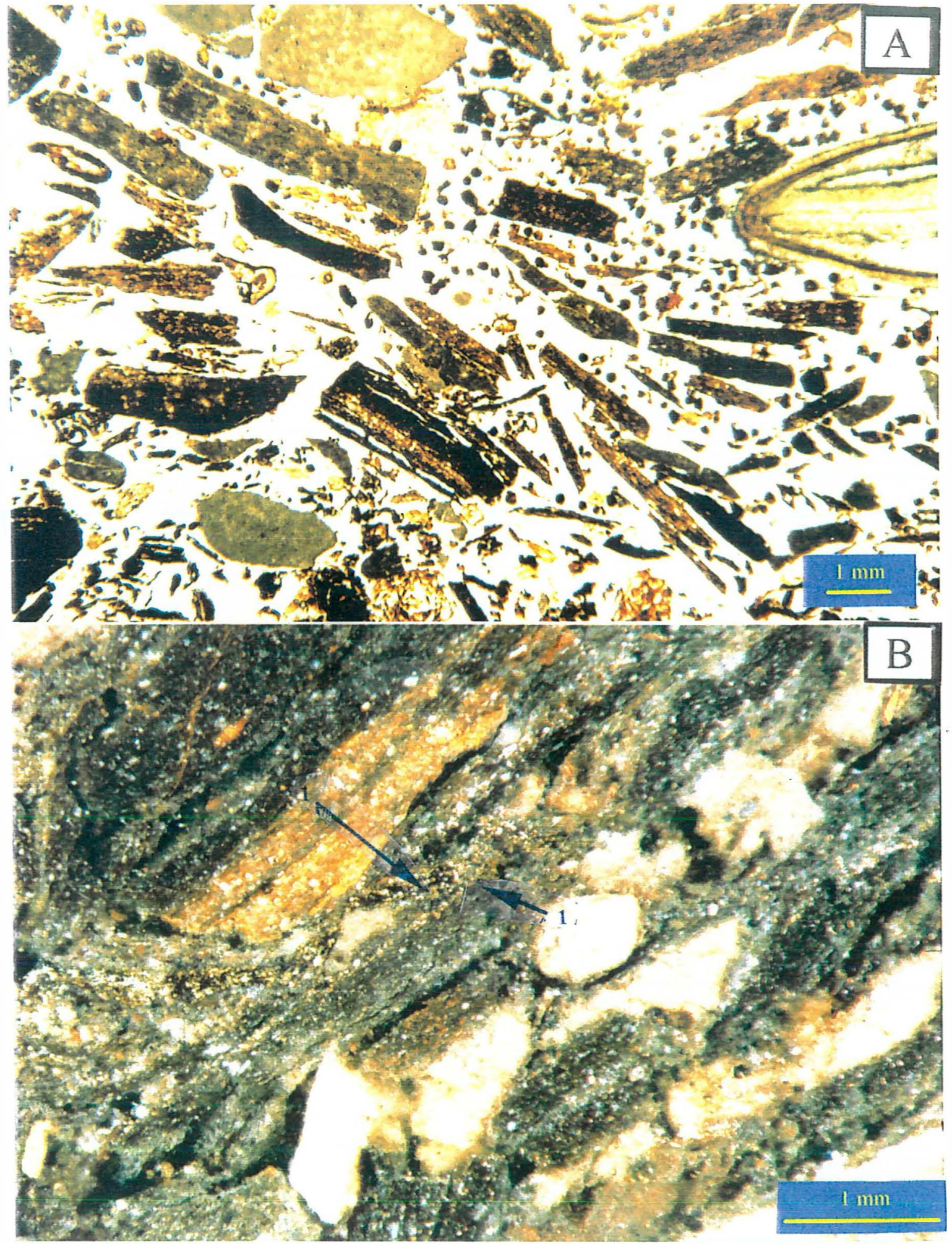

Foto $\&$ - Morfologia do horizonte mineral superficial de P2 (15 anos). A: Perda de plasma e material tíno na transição entre os horizontes $\mathrm{O} / \mathrm{Cl}(+10 \mathrm{x}) ; \mathrm{B})$ Acúmulo de material fino nos espaços entre os fragmentos rochosos no horizonte $\mathrm{Cl}(+25 \mathrm{x})$ inclusive cristais muito pequenos de pirita (1). 
Nota-se também que há mudanças na matiz do horizonte O (10YR) em relação aos horizontes subjacentes $(2,5 \mathrm{Y})$. As mudanças da cor no horizonte $\mathrm{O}$ podem ser explicada pela maior exposição desse material ao microclima de superficie. O horizonte $\mathrm{O}$, por estar na superficie, encontra-se em condição de melhor aeração que as camadas $\mathrm{C} 1$ e $\mathrm{C} 2$.

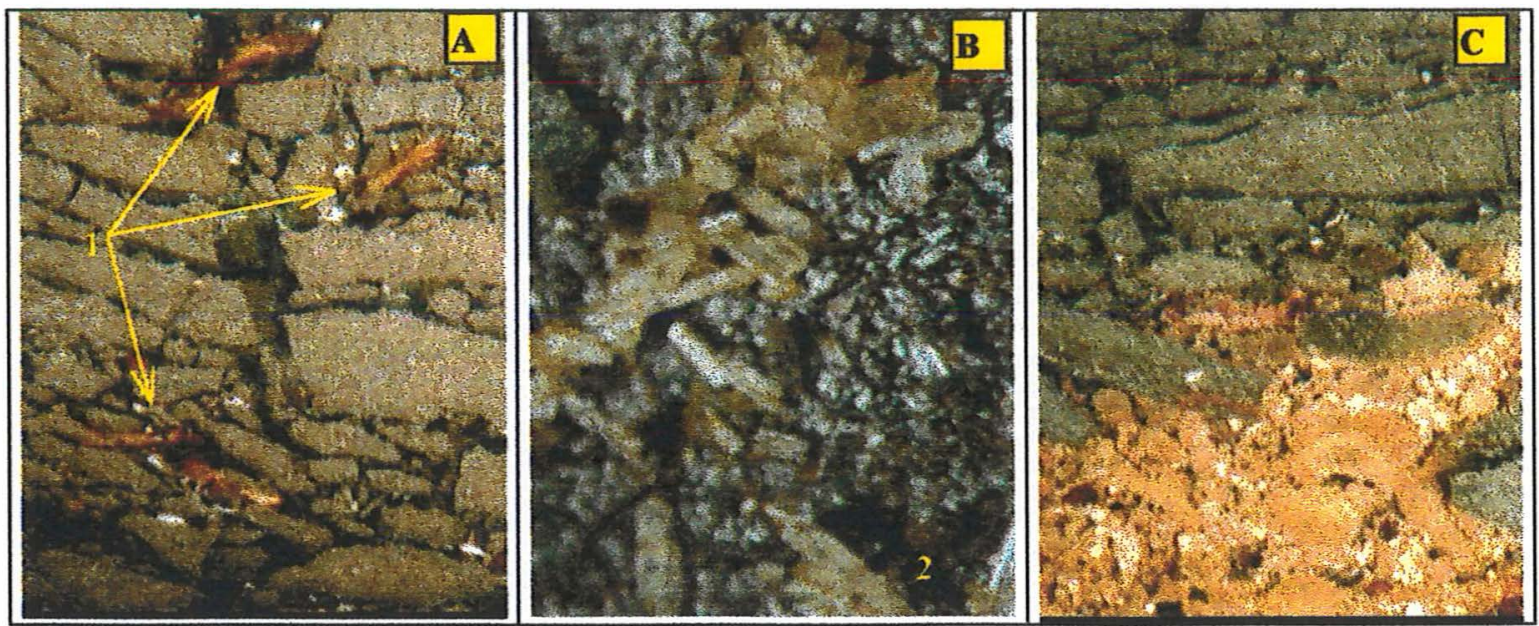

Foto 5 - Alterações de rochas e formação de precipitados em P2 (15 anos) A: Intemperismo biológico do folhelho causado pela ação do sistema radicular (1) no horizonte $\mathrm{Cl}$; $\mathrm{B}$ : Cristais acicularesde gipso que aparecem como eflorescências brancas na parede de P2; C: eflorescência amarelada que se forma na superficie dos folhelhos em alteração.

Devido o material constituinte dos horizontes $\mathrm{C} 1$ e $\mathrm{C} 2$ ser muito rochoso, espera-se um bom caminhamento vertical de água uma vez que, a existência de cascalhos e rochas podem desempenhar um papel positivo através da criação de vias para a entrada e circulação de água e ar (Smith et al., 1971, citados por Quintas-Mosteiro, 1997). Os valores de matiz 2,5Y observados nos horizontes $\mathrm{C} 1$ e $\mathrm{C} 2$ indicam resistência de percolação de água. $\mathrm{O}$ que parece estar em desacordo com o esperado em função dos seus materiais constituintes. Talvez isso possa ser melhor entendido se encararmos os fragmentos de folhelho carbonoso como um reservatório de água neste perfil. Uma parte da água pode percolar devido a abundante porosidade conferida pelo arranjamento aleatório das rochas, mas uma outra parte pode ficar retida entre as laminas dos folhelhos devido a natureza orgânica desta rocha. Quantidades variáveis de água livre que seriam perdidas em ausência de forças capilares exercidas pelas frações finas do solo podem ficar 
temporariamente retidas em canais entre os fragmentos de rocha (Ashby et al., 1984, citado por Quintas-Mosteiro, 1997).

\subsubsection{Trincheira P3 no banco de 32 anos}

O perfil P3 localiza-se em um banco constituído por material rochoso de calcário com sílex e folhelhos pirobetuminosos. Possui uma camada superficial com cerca de $3 \mathrm{~cm}$ de espessura de liteira (L) constituída por restos vegetais ainda identificáveis derivados da parte aérea das leucenas. Abaixo da liteira nota-se a presença de um horizonte orgânico $(0)$ bem característico por sua coloração enegrecida (10YR2/1) e sua estruturação fraca, predominantemente granular muito pequena. Esse horizonte é constituído basicamente de material orgânico não identificado, onde se pode perceber alguns pequenos fragmentos de folhelho em estado de alteração na fração areia e pouco cascalho. Os folhelhos se desfazem quando esmagados entre o polegar e o indicador, ficando com uma textura siltosa.

Subjacente ao horizonte $\mathrm{O}$ encontra-se um horizonte $\mathrm{A}$ com $3 \mathrm{~cm}$ de espessura, formado por volumes de um material argiloso com estruturação moderada em blocos angulares pequenos ou granular pequena a muito pequena e com coloração brunoescuro 7,5YR3/4 e amarelado-avermelhado 5YR4/6. Esses volumes podem variar de tonalidade conforme a presença de canais que podem ser preenchidos com matéria orgânica ou ainda devido a presença de fragmentos rochosos em estado de alteração, adquirindo cores mais escuras: cinzento-avermelhado-escuro 5YR4/2 brunoavermelhado-escuro 5YR3/2 (cores úmidas em campo).

A foto 6 (A e B) retrata a estrutura do horizonte A de P3 (32 anos) e pode-se notar que poros pequenos individualizam os pequenos blocos e grânulos da estrutura. Estes agregados são formados por microagregados arredondados constituídos de matriz plasmática, possuindo abundante microporosidade entre eles (foto $6 \mathrm{~B}$ ). $\mathrm{O}$ material plasmático se mescla ao esqueleto cascalhento constituído de calcários, sílex e 
folhelhos. Observa-se galerias preenchidas por material escurecido, provavelmente devido a matéria orgânica.

A interface entre os horizontes $\mathrm{O}$ e $\mathrm{A}$ apresenta raizes médias e finas dispostas horizontalmente.

Na seqüência são distinguidos 3 horizontes denominados de C1, C2 e C3. Estes horizontes são rochosos com a nítida predominância de calhaus e matacões. Os folhelhos se encontram em vários estados de alteração. Envolvendo os fragmentos de rocha e ocupando os espaços entre estes fragmentos, encontra-se um material fino e escuro predominantemente maciço, podendo apresentar em alguns pontos pouca estrutura provavelmente devido a atividade de organismos do solo. Esse material fino é aqui denominado como matriz pois é um dos substratos onde se desenvolvem o sistema radicular. As raízes são muito comuns, encontrando-se raízes médias e finas que se desenvolvem entre os fragmentos rochosos, contornando os cascalhos e calhaus e penetrando entre as placas dos folhelhos.

$\mathrm{O}$ horizonte $\mathrm{Cl}$ é distinguido das demais por apresentar uma cor mais escura de preto 2,5Y2/0 a cinzento muito escuro 2,5Y3/0 (úmido, matriz). Esse escurecimento provavelmente deve estar relacionado ao acúmulo de ácidos orgânicos. Os horizontes $\mathrm{C} 2$ e $\mathrm{C} 3$ apresentam cores mais claras. Em C2 predominam bruno-acinzentado muito escuro 10R3/2 e 2,5Y4/4 e em C3, bruno-acinzentado escuro 10YR3/3 e brunooliváceo 2,5Y4/4 (úmido, matriz). Os menores valores nas cores de C2 e C3 são provavelmente devido ao menor acúmulo de material orgânico nestas camadas.

$\mathrm{O}$ horizonte $\mathrm{Cl}$ também se apresenta mais coeso, com maior abundância de raízes finas e a ausência de cristais de sal visíveis a sua parede. 


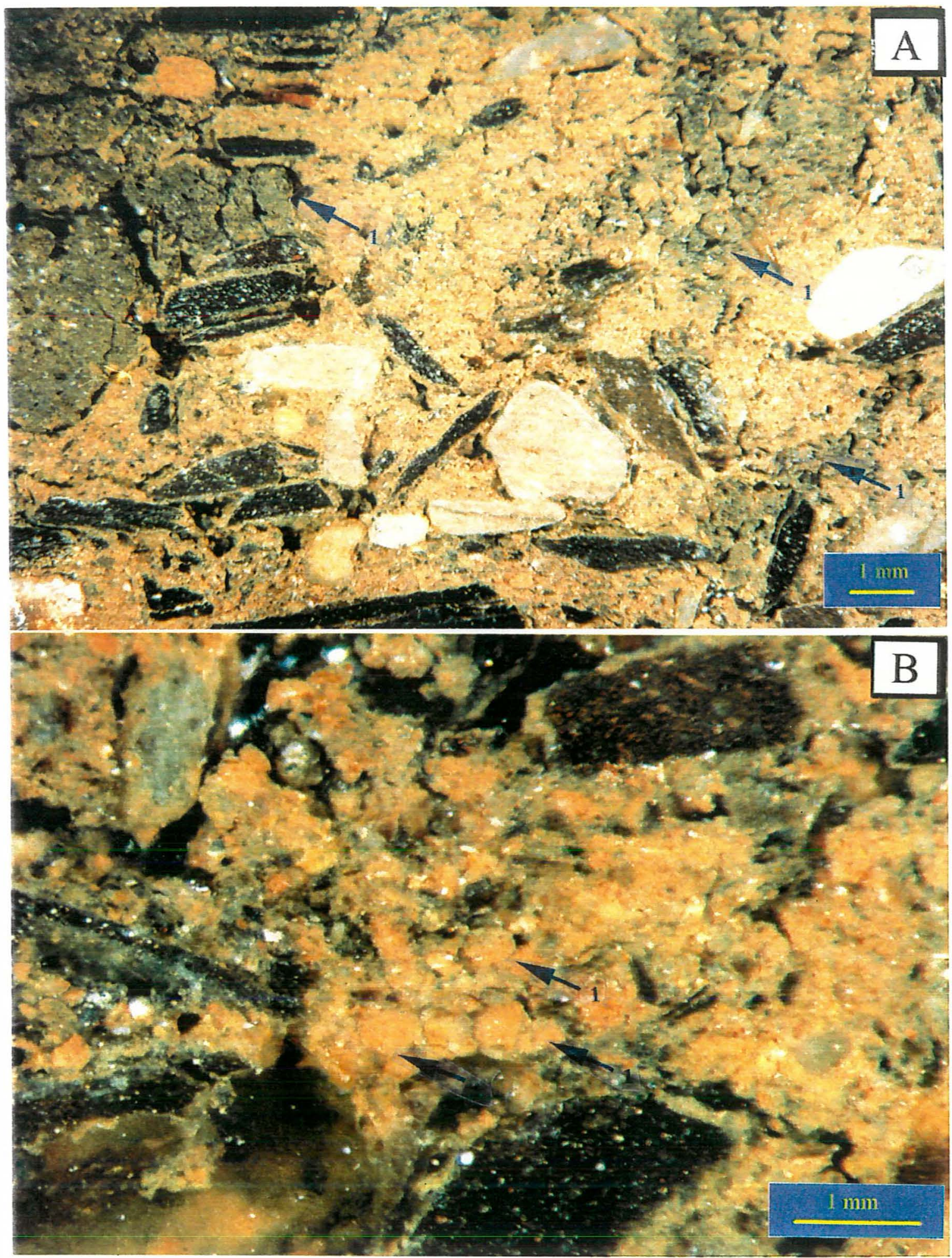

Foto 6 - Estrutura dos horizontes A de P3 (32 anos), A: Estrutura granular média (+12x), notar bioporos preenchidos por coprólitos e micro-agregados arredondados escurecidos (1); B Micro-agregados arredondados (1) que constituem os agregados granulares de A do perfil P3 (32 anos). 
A rochosidade predomina por todo o perfil a partir de $\mathrm{Cl}$ e a porosidade é representada por fissuras existentes nos folhelhos e por vãos decorrentes do empilhamento aleatório dos fragmentos. Segundo Pedersen et al. (1980) a porosidade dos solos de mina é menor que em solos naturais, porém os poros em solos de mina são tipicamente maiores. $\mathrm{O}$ arranjamento dos fragmentos rochosos em muitos solos de mina, criam vazios que podem variar de alguns centímetros até meio metro (Ciolkosz et al., 1985). Estes espaços vazios existentes ao longo do perfil favorecem a percolação e circulação de água. Com o intemperismo e desagregação da rocha, criam-se espaços para o enraizamento (Ashby et al., 1971, citado por Quintas-Mosteiro, 1997).

As raizes finas crescem na matriz, em planos de esfoliação dos folhelhos e aderidas à superficie das rochas. Raízes médias se desenvolvem tortuosas devido à resistência fisica oferecida pelos fragmentos rochosos. Monterroso-Martinez (1995) observou que as raizes principais de árvores podem atingir grandes profundidades no solo de mina através de espaços existentes entre os fragmentos maiores mas, na maioria dos casos, o sistema radicular apresenta um aspecto desordenado pois as raízes podem desenvolver-se nos poros nem sempre contínuos, rodeando as zonas maciças e os fragmentos de rocha.

Como ocorre em P2 (15 anos), as raízes que se desenvolvem nos planos de fendilhamento dos folhelhos provocam a fragmentação desta rocha, evidenciando seu intemperismo biológico.

A eflorescência, devido a grande quantidade de sulfato de cálcio que se forma na superficie das rochas e raízes, aumenta de C2 para C3.

\subsubsection{Trincheira P4 no banco de 32 anos}

Encontra-se nas mesmas condições de P3, porém o horizonte orgânico preto 2,5Y2/0 está mesclado com material bruno-amarelado-escuro 10YR4/4, brunoescuro 10YR4/3, bruno-acinzentado-escuro 10YR4/2, bruno muito escuro 10YR3/2 (úmido). 
O horizonte A, com $3 \mathrm{~cm}$ de espessura, possui estrutura moderada predominando a granular muito pequena sobre a muito pequena a pequena em blocos. Apresenta cores brunas como no horizonte A de P3, porém, em alguns pontos, é mais escurecido. $\mathrm{O}$ escurecimento do horizonte $\mathrm{A}$, a mescla do horizonte orgânico com litorrelíquias de folhelho e material argiloso, pode ser explicado como uma conseqüência da atividade biológica, como já citado em P1.

O domínio de fragmentos rochosos maiores como os calhaus e matacões fica mais acentuada a partir de $\mathrm{Cl}$ e tem aspecto semelhante ao da trincheira P3. A porosidade é representada por fissuras inerentes aos fragmentos de folhelho e espaços vazios devido ao empilhamento aleatório das rochas. As raízes se desenvolvem por todo o perfil e apresentam um comportamento semelhante ao descrito em P3. As raízes finas se desenvolvem na matriz do rejeito, rente à superficie das rochas e nos planos de ruptura dos folhelhos em alteração. Enquanto que as raízes médias e grossas ocupam os espaços vazios entre os fragmentos rochosos e os contornam procurando caminho entre os calhaus e matacões, apresentando tortuosidade.

Observa-se em todo perfil (P3 e P4) que há material fino formado pela mescla de argila, matéria orgânica e pequenos fragmentos de rocha na fração areia, ocupando os espaços existentes entre os fragmentos rochosos maiores e conferindo aderência entre os fragmentos. Esse material fino é aqui denominado de matriz. A alteração dos folhelhos é visivelmente intensificada pela presença de raizes que os penetram e colaboram na fragmentação dessa rocha.

Apesar da predominância de fragmentos rochosos maiores a partir de $\mathrm{Cl}$, nota-se pedoturbações de origem biológica como galerias e agregação de material fino formando uma estrutura granular fraca em alguns pontos desses perfis. Como a estrutura, as pedoturbações também diminuem com o aumento da profundidade, enquanto os cristais de sais, presentes nas paredes destes perfis, aumentam em tamanho e quantidade. 


\subsubsection{Trincheira P5 no banco de 32 anos}

A trincheira aberta na área de pastagem apresentou um horizonte A de 4 $\mathrm{cm}$ de espessura, escurecido pela matéria orgânica, onde é comum encontrar fragmentos de folhelho, siltito ou calcário com sílex nas frações areia e cascalho. A estrutura predominante é a moderada, pequena a muito pequena granular, mas pode-se observar blocos muito pequenos e também laminar em decorrência do pisoteio do gado. Existe também neste horizonte, uma considerável população de minhocas e outros organismos do solo, principalmente ao redor das tosseiras.

$\mathrm{O}$ horizonte A na trincheira P5, apesar da área ter sofrido um nivelamento em superficie em 1992, apresenta uma espessura semelhante a dos horizontes A de P3 e P4, abertos na área de leucenas no mesmo banco de deposição. Isso pode ser devido ao manejo que a área de P5 sofreu antes da implantação da pastagem, à maior atividade biológica e ao tipo de vegetação nesta área. Essa vegetação é constituída de gramíneas e leucena consorciadas para a pastagem. Uma boa cobertura de gramínea e leguminosas forrageiras promoveram maior efeito na agregação do solo de mina de carvão que árvores, Wilson (1957).

A vegetação herbácea contribui com conteúdos consideráveis de matéria orgânica na forma de raízes finas e rizomas, os quais apresentam íntima ligação às partículas do solo e penetram entre as lâminas, originando segregações orgânicas que, possivelmente, levam a um desenvolvimento e alteração dos horizontes, Soave (1996).

Como visto por Thomas e Jansen (1985), a cobertura de gramíneas e leguminosas, o manejo, o maior conteúdo de argila do rejeito e a presença de uma fauna do solo ativa podem favorecer a formação agregados e portanto acelerar a evolução pedogenética do solo de mina.

As micrografias do horizonte A do perfil P5 (foto 7) ilustram a estrutura moderada granular onde, notam-se agregados granulares arredondados em meio a fragmentos de calcário, sílex e folhelho. Alguns agregados apresentam-se escurecidos provavelmente devido à matéria orgânica (foto 7 A). A porosidade é contínua e alguns 
canais apresentam-sa preenchidos por microagregados arredondados de origem biológica (foto $7 \mathrm{~B}$ ).

Subjacente a este horizonte $\mathrm{A}$ tem-se horizonte $\mathrm{Cl}$ constituído de cascalhos de folhelho em alteração com matriz bruno-oliváceo-claro 2,5Y5/4. A matriz une os fragmentos rochosos conferindo certa aderência entre os mesmos e formando um volume de aspecto maciço. Nota-se entretanto, algumas galerias de tamanho médio e a formação de agregados granulares ou blocos em alguns pontos desse horizonte. As raízes de gramíneas desenvolvem-se normalmente neste meio, penetrando na matriz, entre os fragmentos de folhelho e siltito e rentes a superficie de outros fragmentos rochosos. $\mathrm{O}$ valor e o croma do material podem indicar pouca influência da matéria orgânica, além de moderada intensidade da cor. $\mathrm{O}$ matiz $2,5 \mathrm{Y}$ possivelmente deve estar relacionado a retenção de água na porosidadde existente nos fragmentos de folhelho.

A seguir encontra-se o horizonte C2 adensado, argiloso e cascalhento, composto por cascalhos e calhaus de folhelhos, calcários e sílex em estado de alteração mesclados à argila que assume cores variando de tons cinza e até avermelhados.

Abaixo deste horizonte adensado, encontra-se o horizonte $\mathrm{C} 3$ constituído por folhelhos quebradiços e pouco alterados, onde nota-se a atuação do intemperismo químico devido a oxidação do ferro nos planos de ruptura dos folhelhos. Nota-se também calhaus e matacões de calcários, muito pouco material fino e abundante formação de cristais de $\mathrm{CaSO}_{4}$. 


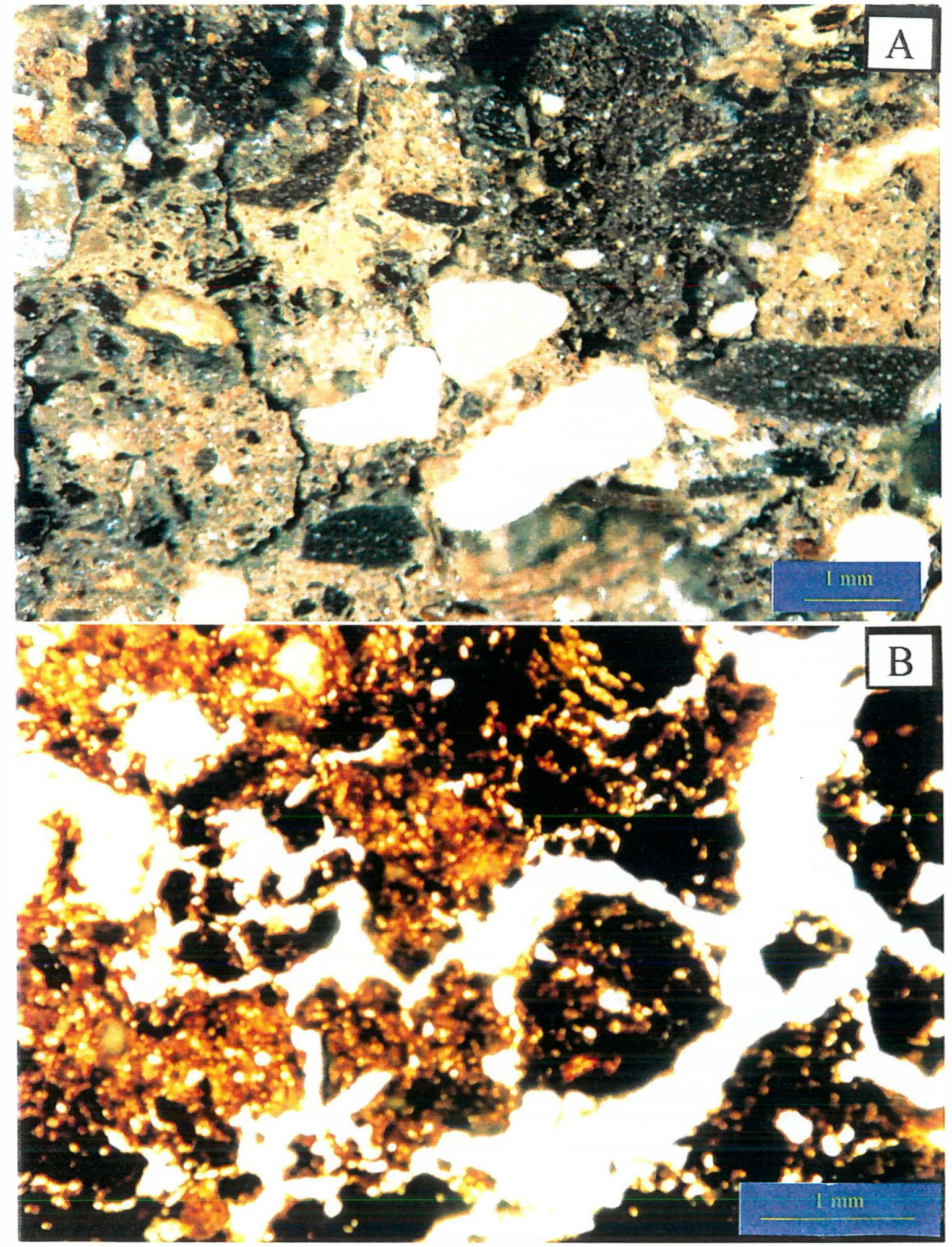

Foto 7 - Estrutura do horizonte A de P5 (32 anos). A: Estrutura granular média (+16x); B: Porosidade e agregados de origem biológica $(+25 \mathrm{x})$. 


\subsection{Características Físicas}

\subsubsection{Proporções de granulometria do material coletado $(<50 \mathrm{~mm})$}

Devido ao grande volume ocupado por fragmentos rochosos e à grande heterogeneidade granulométrica do material, sendo comum se encontrar matacões de cerca de $50 \mathrm{~cm}$ de diâmetro ou mais, misturados a pouca quantidade de material fino com granulometria próxima a $2 \mathrm{~mm}$, optou-se por selecionar em campo um diâmetro médio inferior a $50 \mathrm{~mm}$ para a coleta de material para as análises. Esse material foi então exposto ao secamento ao ar e peneirado usando-se peneiras de 20 e $2 \mathrm{~mm}$. O material com diâmetro inferior a $2 \mathrm{~mm}$ foi tomado como terra fina. $\mathrm{O}$ volume que ficava entre as peneiras de 2 e $20 \mathrm{~mm}$ foi tido como cascalhos e a parte retida na peneira de $20 \mathrm{~mm}$ foi classificada como calhaus.

Assim, como em Quintas-Mosteiro (1997), os valores obtidos do conteúdo de materiais grosseiro são orientativos, porém não definem totalmente o grau de pedregosidade das trincheiras estudadas.

Todos os perfis possuem uma natureza rochosa, com predomínio de calhaus e matacões, principalmente os formados pela deposição dos fragmentos de lajão (calcário + sílex e folhelhos) como os perfis P2, P3, P4 e P5. No perfil P1 os fragmentos grosseiros estão misturados a maiores proporções de material herdado do solo que foi removido como também blocos de argilito. Por isso, que apesar de rochoso, o perfil P1 tem maior conteúdo de material fino que os demais perfis.

As figuras 4 a 8 ilustram o comportamento do material coletado quanto as proporções de terra fina, cascalhos e calhaus nos perfis com diferentes idade e sobre diferentes formações vegetais. 
P1

A

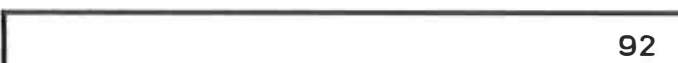

92

C 1

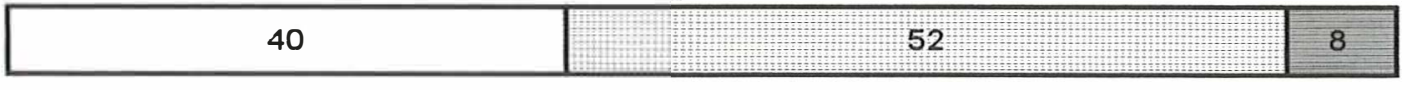

C 2

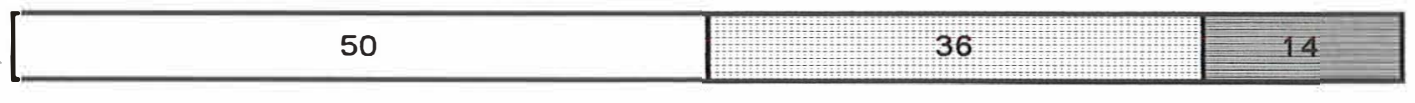

$\square \%<2 \mathrm{~mm}$

$\square \% 2-20 \mathrm{~mm}$

口\% 20-50 $\mathrm{mm}$

Figura 4 - Proporção entre as classes granulométricas do material coletado do perfil aberto na área de rejeito com 2 anos de deposição, sobre vegetação de transição de gramíneas e leucena.

P 2

0

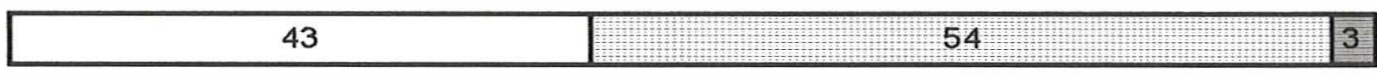

C 1

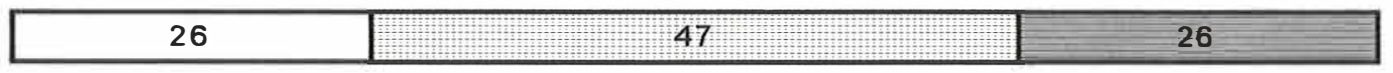

C 2a

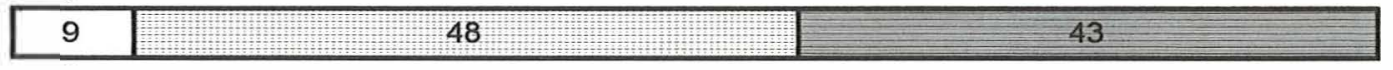

c 2b

13

60

$\underline{27}$

ㅁ\% $<2 \mathrm{~mm}$

口\% 2-20mm

믕 20-50 m m

Figura 5 - Proporção entre as classes granulométricas do material coletado do perfil aberto na área de rejeito com 15 anos de deposição sobre leucena. 


\section{P 3}

o 70 $1+30$

A 64

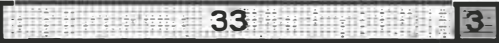

C1 52 31

C2 c 3 $921 \quad$ 1)

$\square \%<2 \mathrm{~mm}$

口\% 2-20m m

回\% 20-50 m m

Figura 6 - Proporção entre as classes granulométricas do material coletado do perfil aberto na área de rejeito com 32 anos de deposição, sobre vegetação de leucena.

\section{P 4}

0

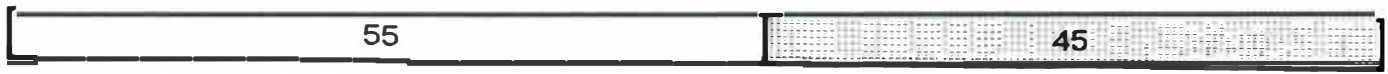

A

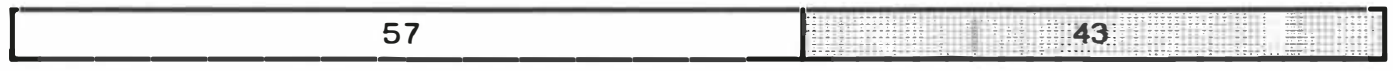

C 1

C 2

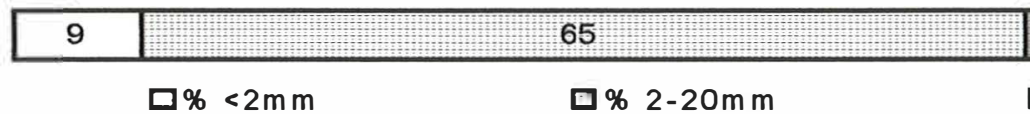

26

回\% 20-50 m m

Figura 7 - Proporção entre as classes granulométricas do material coletado do perfil aberto na área de rejeito com 32 anos de deposição, sobre vegetação de leucena.

\section{P 5}

A

\begin{tabular}{|l|l|l|}
\hline 55 & 45 \\
\hline
\end{tabular}

C 1

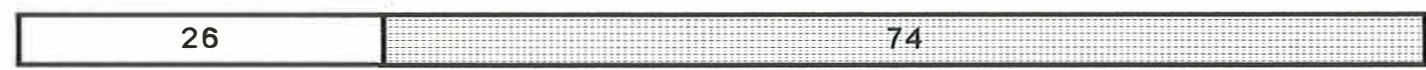

C2

c3 7

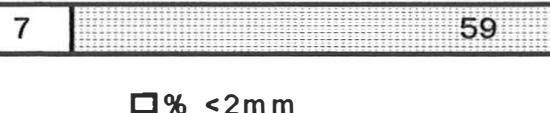

口\% $<2 \mathrm{~mm}$

口\% 2-20mm 35

口\% 20-50 m m

Figura 8 - Proporção entre as classes granulométricas do material coletado do perfil aberto na área de rejeito com 32 anos de deposição, sobre consorcio de gramíneas e leucena para pastagem. 
De maneira geral há um predomínio de cascalhos (fragmentos com diâmetro variando entre de 2 a $20 \mathrm{~mm}$ ) sobre os calhaus (fragmentos com diâmetro entre 20 a $50 \mathrm{~mm}$ ) no material coletado. Porém, para efeitos práticos, considera-se aqui como material grosseiro a soma dos cascalhos e calhaus, portanto entende-se aqui como material grosseiro fragmentos rochosos correspondentes às frações de diâmetro variável entre 2 e $50 \mathrm{~mm}$.

Apesar da heterogeneidade do material e de possíveis seleções aleatórias no momento de deposição do rejeito, pode-se notar em todos os perfis que o material fino $(<2 \mathrm{~mm})$ alcança maiores proporções nos horizontes superficiais, apresentando uma tendência a diminuir com a profundidade. Isso fica mais claro nos perfis abertos na área de 32 anos. Almeida (1983) e Soave (1996) comentam um maior intemperismo na superficie destas áreas de mineração de calcário da Formação Irati. Dessa forma, o fato de que há maiores proporções de materiais finos na superficie dos perfis aqui estudados, pode ser interpertado como uma consequência da ação do intemperismo e de fatores pedogenéticos

A proporção em peso de material grosseiro neste estudo varia entre $8 \% \mathrm{e}$ $57 \%$ nos horizontes superficiais e, nos horizontes mais profundos, oscila entre $50 \%$ e $93 \%$.

O perfil P1 apresenta maior conteúdo de material com diâmetro inferior a $2 \mathrm{~mm}$ tanto no horizonte A como em profundidade em relação aos demais perfis. Isso pode estar relacionado à heterogeneidade do material, já que P1 está situado em um banco onde foi depositado um material com maior conteúdo de argila em relação aos demais bancos, predominantemente rochosos.

Pode-se notar que a pedregosidade neste solo de mina em desenvolvimento é elevada em relação a outros tipos de solo, sendo esta uma característica comum na maioria dos solos de mina. Pedersen et al. (1980), também encontraram valores elevados de pedregosidade variando de $64 \%$, em horizontes $\mathrm{A}$, até 93\% em horizontes C. Ciolkosz et al. (1985), relataram que o conteúdo de fragmentos grossos variaram entre 40 e $60 \%$ na superficie e acima de $70 \%$ no subsolo. 
Com relação à idade do solo, comparando-se os perfis abertos em rejeitos pedregosos (P2, P3, P4 e P5), há uma tendência de solos formados em montes mais velhos (32 anos) apresentarem maiores quantidades de TFSA em superficie (55 a 70\%) que o solo formado no monte de 15 anos (43\%).

Embora o horizonte superficial do perfil P2 (15 anos) apresentasse 43\% de material com diâmetro inferior a $2 \mathrm{~mm}$ (TFSA), este ainda não é composto por material de solo, isso é, não observou-se a formação de um horizonte tipicamente mineral agregado. Nesse horizonte é encontrado com maior abundância micro-agregados granulares muito pequenos de material orgânico (pelotas) e alguns fragmentos de rocha em avançado estado de alteração.

$\mathrm{O}$ perfil $\mathrm{Pl}$, apesar de ter apenas dois anos, apresenta maior quantidade de material com diâmetro inferior a dois milímetros em relação aos outros, mas isso é devido P1 encontrar-se em um banco com maiores teores de material argiloso ou siltoso como argilitos e siltitos mesclados aos fragmentos rochosos. Mesmo assim fica evidente a maior susceptibilidade ao intemperismo dos fragmentos rochosos próximos à superficie (figura 4), onde apenas $8 \%$ do material (em peso) permaneceu com diâmetro maior que $2 \mathrm{~mm}$.

Um rápido decréscimo no tamanho de partícula na superficie de bancos de rejeito num curto período de tempo também foi encontrado por Down (1975 a). Outros autores têm observado que os fragmentos se alteram rapidamente em material de solo (< $2 \mathrm{~mm}$ ) próximo à superficie dos solos de mina (Schafer et al., 1980; Jonhson et al, 1982; Ciolkosz et al. 1985).

Dependendo do tipo de rocha e das operações de manejo do rejeito, a pedregosidade pode acarretar em algumas conseqüências negativas e/ ou desempenhar papeis positivos às propriedades dos solos de mina.

O maior aprofundamento das raízes em solos arenosos, pode compensar a diminuição do volume das mesmas devido a presença de pedras (Monterroso-Martinez, 1995). Além disso a medida que se avança o intemperismo e a desagregação da rocha se criam espaços para o enraizamento e canais para a circulação de água e ar (Ashby, et al., 1984, citado por Quintas-Mosteiro, 1997). 
A presença de fragmentos rochosos maiores que $2 \mathrm{~mm}$ pode ainda contribuir com outro aspecto favorável aos atributos fisicos dos solos de mina. As frações grossas podem reter umidade e ser responsável pelo fornecimento de água para as plantas em solos pedregosos (Coile, 1952). A água disponivel em fragmentos de folhelho pode chegar a 17\% (Hanson \& Blevins, 1979) ou a 19\% (Hower et al., 1992) e essa água pode desempenhar um papel significativo no crescimento de plantas em solos que contém alta porcentagem de fragmentos grossos, como também em áreas de mineração.

Em função da discussão apresentada neste item, fica evidente que a rochosidade, sendo uma característica comum dos solos de mina, merece maiores estudos para melhor compreensão de suas propriedade, afim de que se possa lançar propostas de aproveitamento do material ou ainda de monitoramento da restauração das áreas afetadas pela atividade de mineração.

\subsubsection{Granulometria e classes texturais}

A análise granulométrica permite identificar as concentrações das frações silte, argila e areia.

As figuras 9 a 13 ilustram a distribuição das partículas inerentes a fração TFSA ( $<2 \mathrm{~mm})$ nos horizontes dos perfis P1, P2, P3, P4 e P5, abertos nas áreas de 2, 15 e 32 anos, respectivamente.

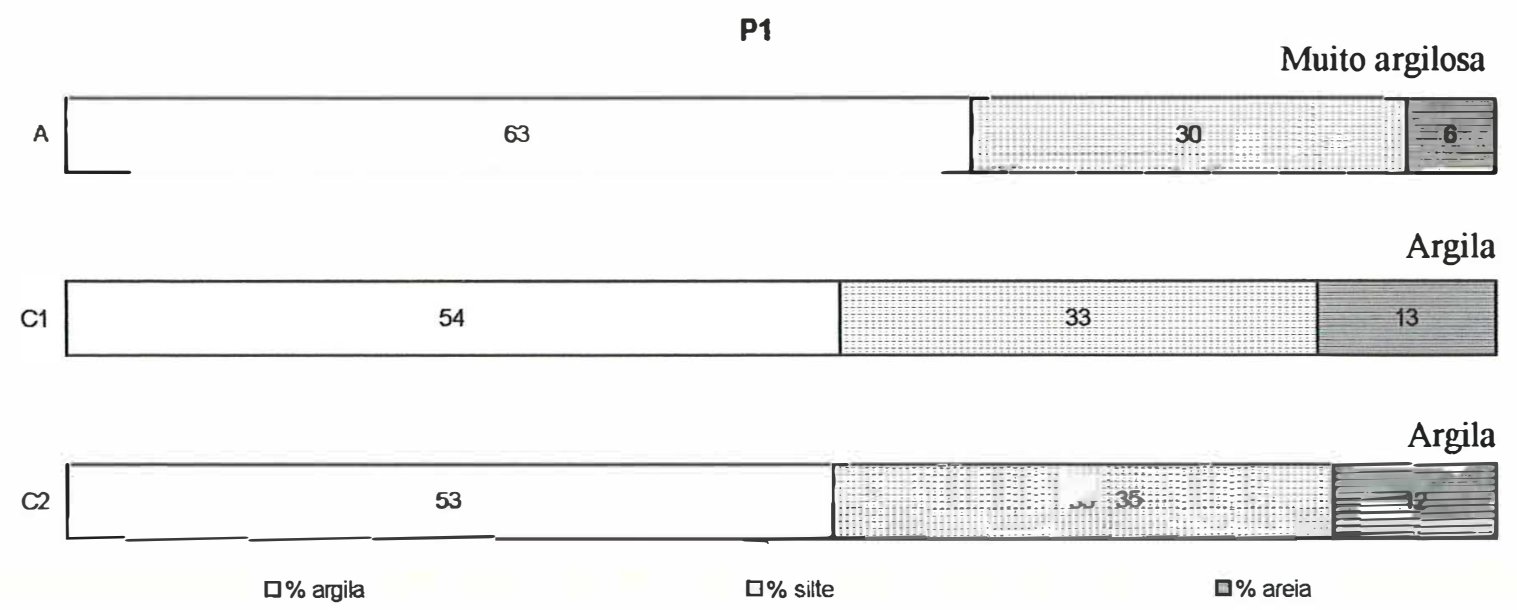

Figura 9 - Proporção entre as classes granulométricas da TFSA do perfil aberto na área de rejeito com 2 anos de deposição sobre vegetação de transição de gramíneas e leucena. 
P2

Franco argilo arenosa

○

30

24

Franco argilo arenosa

C1

30

23

Franco argilo arenosa

$\mathrm{C} 2$

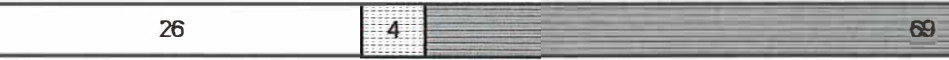

$\mathrm{C}_{2}$

\begin{tabular}{|l|l|ll|}
\hline 33 & 2 & 65 & Franco argilo arenosa \\
\hline
\end{tabular}

$\square \%$ argila

口\% silte

口\% areia

Figura 10 - Proporção entre as classes granulométricas da TFSA do perfil aberto na área de rejeito com 15 anos de deposição sobre leucena.

P3

Franco argilosa

0

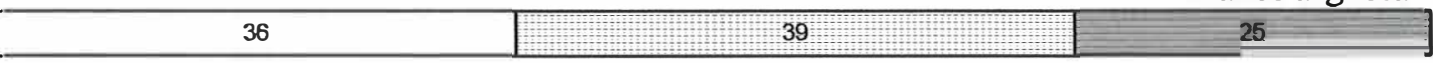

Argila siltosa

A

42 42 校

C1

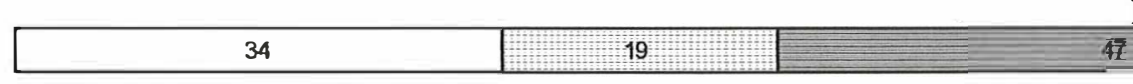

Franco argilo arenosa

C2

32

21

Franco argilo arenosa

C2

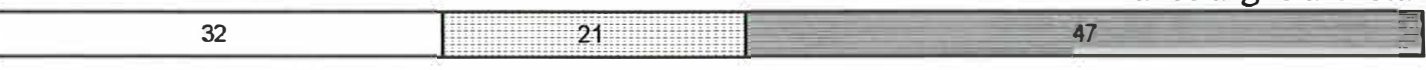

$\mathbf{C 3}$

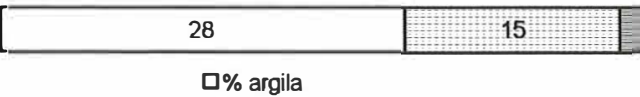

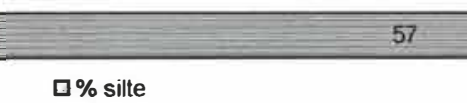

Franco argilo arenosa

Figura 11 - Proporção entre as classes granulométricas da TFSA do perfil aberto na área de rejeito com 32 anos de deposição sobre leucena. 


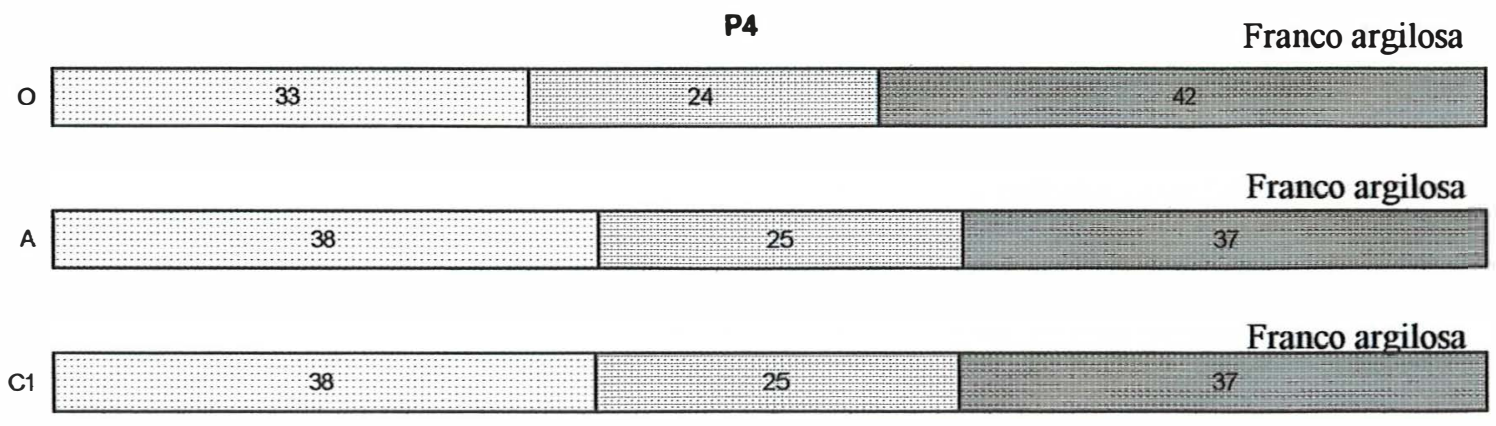

Franco argilo aresa

$\mathrm{C2}$

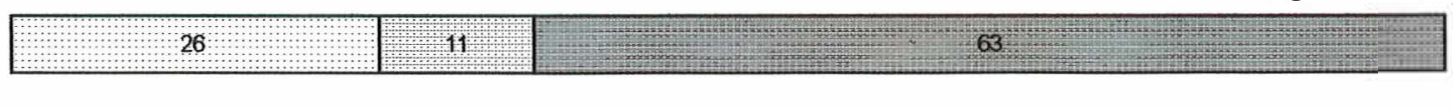

口\% agila

$\mathbf{0} \%$ silte

G\% areia

Figura 12 - Proporção entre as classes granulométricas da TFSA do perfil aberto na área de rejeito com 32 anos de deposição sobre leucena.

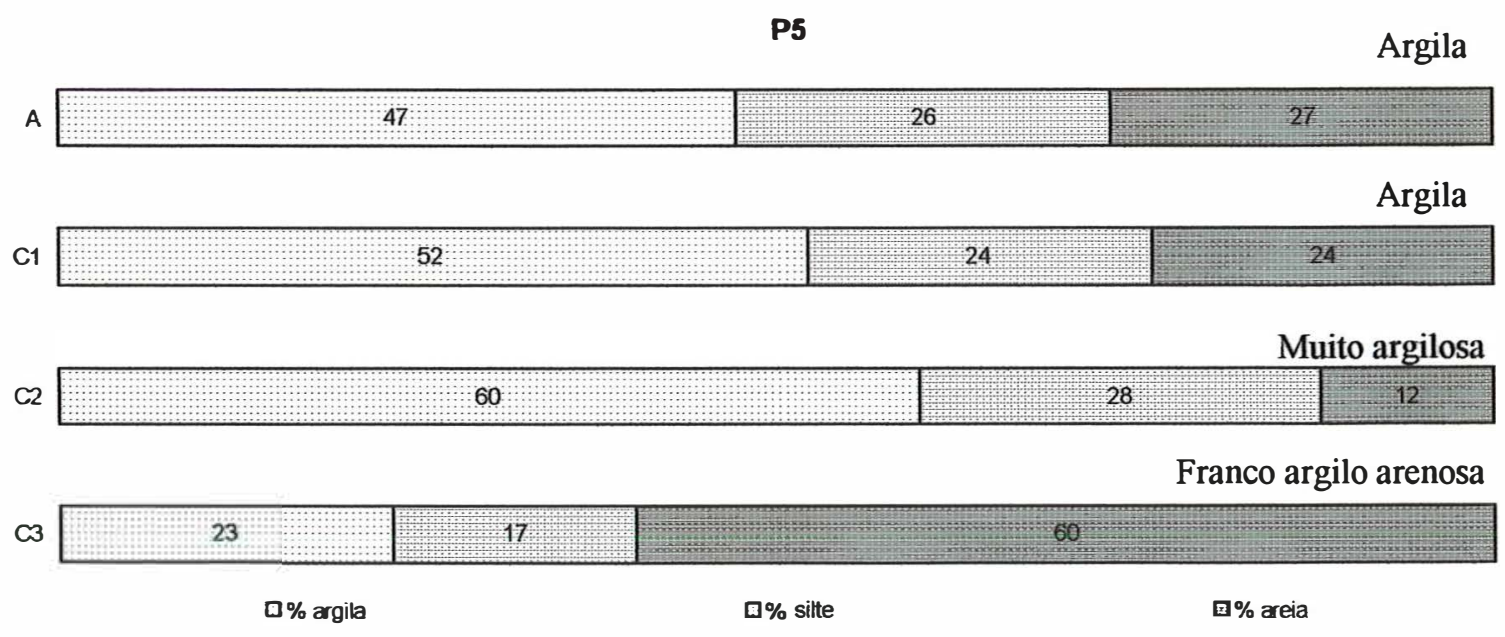

Figura 13 - Proporção entre as classes granulométricas da TFSA do perfil aberto na área de rejeito com 32 anos de deposição sobre consorcio de gramíneas e leucena para pastagem.

De maneira geral, há um predomínio de texturas argilosas nos horizontes superficiais, enquanto que ocorre predomínio de classes arenosas em profundidade.

Os perfis abertos em bancos mais rochosos (P2, P3, P4 e P5) apresentam um aumento da fração silte com o decréscimo profundidade, esse aumento é mais evidente no perfil $\mathrm{P} 2$ na área de 15 anos de repouso, onde o intemperismo pode estar menos avançado em relação às áreas mais velhas (P3, P4 e P5).

Uma diminuição de material grosseiro e aumento da fração silte em alguns perfis de solos de mina foram observados por Haering et al. (1993). Hower et al. (1992) 
encontram incrementos de até $35 \%$ principalmente na fração silte após simulação de intemperismo de folhelhos.

Apesar de P2 não apresentar mudanças na classe textural, pode-se notar uma diminuição da fração areia e um claro aumento da fração silte nos horizontes superficiais $\mathrm{O}$ e $\mathrm{C} 1$ em relação aos horizontes mais profundos $\mathrm{C} 2_{1}$ e $\mathrm{C} 2_{2}$ (figura 10). Para Rai et al. (1974), citados por Schafer et al. (1980), os fragmentos mais frágeis se alteram mais rapidamente perto da superficie do solo, mas uma mudança gradual na textura leva um certo período de tempo.

Uma mudança na textura é notada entretanto no perfil P3, na área de 32 anos. Este perfil apresenta um horizonte A que, pela análise granulométrica, possui textura argilo-siltosa. Segundo Quintas-Mosteiro (1997), a intemperização dos folhelhos é bastante rápida e em poucos anos pode-se incrementar de forma considerável o material coloidal.

Ainda em P3, abaixo do horizonte A não se percebe a mudança textural. Schafer et al. (1980), argumentam que fragmentos frágeis de rochas enterrados abaixo da camada superficial do solo não alteram rapidamente.

$\mathrm{O}$ perfil $\mathrm{P} 4$, apresenta maior quantidade de areia que o perfil $\mathrm{P} 3$ aberto na mesma área de rejeito e sobre o mesmo tipo de vegetação (área com 32 anos de deposição, sobre vegetação de leucenas). Isso provavelmente é devido à abundante pedoturbação encontrada em $\mathrm{P} 4$, pois a atividade de organismos do solo pode trazer partículas mais grossas de horizontes inferiores à superficie, o que poderia estar colaborando para aumentar o conteúdo de areia nos horizontes O e A em P4. Embora P3 também apresente sinais de pedoturbação, estes são menos freqüentes que em P4.

Através dos dados da análise granulométrica não é possível evidenciar translocação de argila nestes solos de mina. No entanto, o perfil P5 apresenta um aumento do teor de argila nos horizontes $\mathrm{C} 1$ e $\mathrm{C} 2$. Isso provavelmente não pode estar relacionado à translocação de argila e sim à diferenças texturais dos próprios materiais depositados (Ciolkosz et al., 1985). 
$\mathrm{O}$ decréscimo brusco no teor de argila no horizonte $\mathrm{C} 3$ de $\mathrm{P} 5$ é devido primariamente ao material depositado neste horizonte diferir do sobrejecente, o folhelho era pouco alterado, solto e sem adesão ou coesividade. A estratificação de rejeitos contrastantes é comum em solos de mina, além da alteração dos fragmentos rochosos acontecer mais lentamente em profundidade que em superficie (Schafer et al., 1980).

\subsubsection{Fracionamento da areia}

A areia nos rejeitos de calcário da Formação Irati é constituída por litorelíquias provenientes da desagregação fisica da rocha, constituídas por betume, elementos piritóides, carbonatos, marmorinas e argilãs (Soave, 1996).

\section{P1}

A

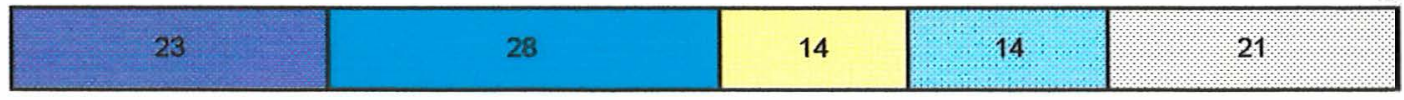

c1

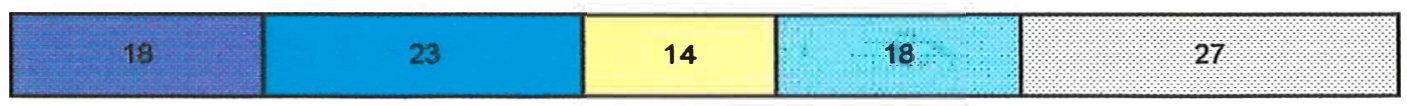

C2

\begin{tabular}{|l|l|l|l|l}
\hline 13 & 21 & 13 & $18 \cdots$
\end{tabular}

घ\% areia muito grossa

$\%$ areia grossa

$\square \%$ areia media

G \% areia fina

$\square \%$ areia muito fina

Figura 14 - Fracionamento da areia do perfil P1. 
P2
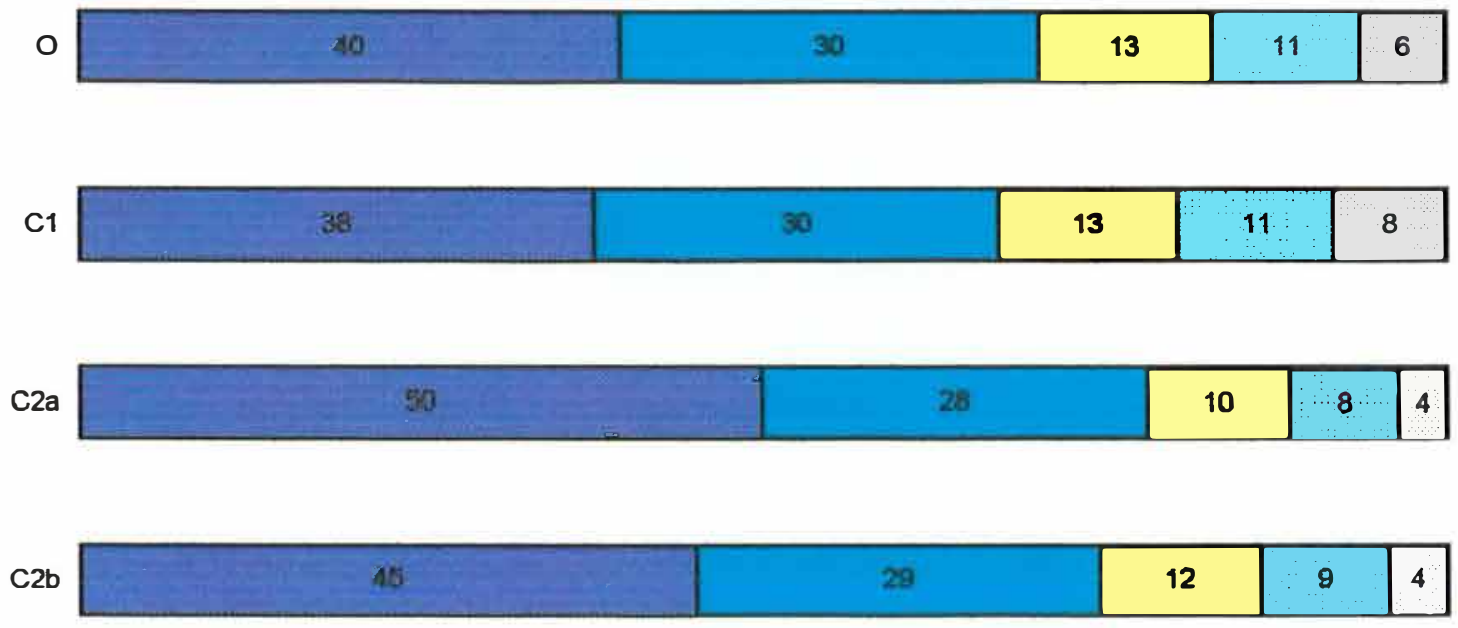

口 areia muito grossa $\quad \square \%$ areia grossa $\quad \square \%$ areia media $\quad \square \%$ areia fina $\quad \square \%$ areia muito fina

Figura 15 - Fracionamento da areia do perfil P2.

P3

○

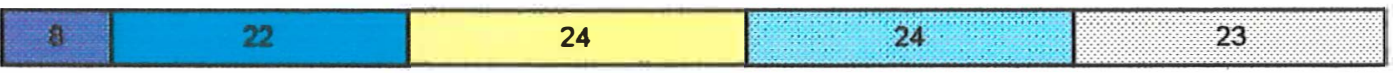

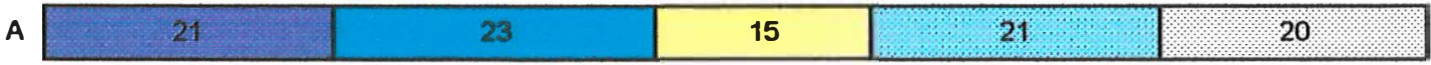

C1

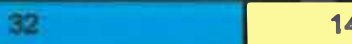

C2

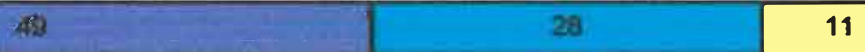

с3

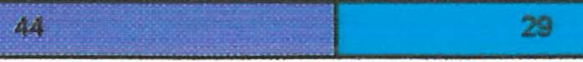

12

10... 5

口\% areia muito grossa

\% areia grossa

$\square \%$ areia media

口 \% areia fina

$\square \%$ areia muito fina

Figura 16 - Fracionamento da areia do perfil P3. 
○

L

\begin{tabular}{|l|l|l|l|l|l}
\hline 30 & 26 & 19 & 10 \\
\hline
\end{tabular}

A

\begin{tabular}{|l|l|l|l|l|}
\hline 30 & 28 & 16 & $16: 10$ \\
\hline
\end{tabular}

C1

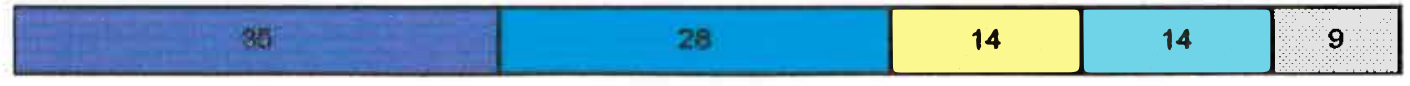

C2

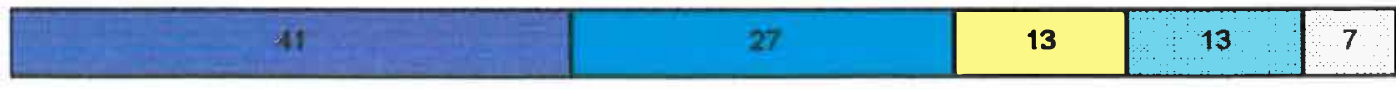

무 areia muito grossa

을 areia grossa

$\square \%$ areia media

$\square \%$ areia fina

$\square \%$ areia muito fina

Figura 17 - Fracionamento da areia do perfil P4.

P5

A

29

c1

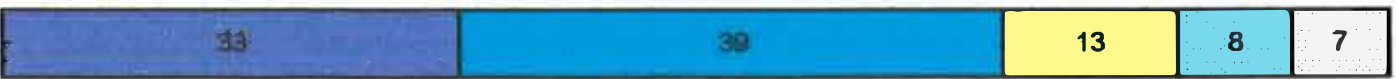

$\mathrm{C2}$

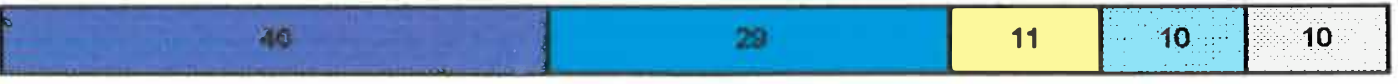

C3

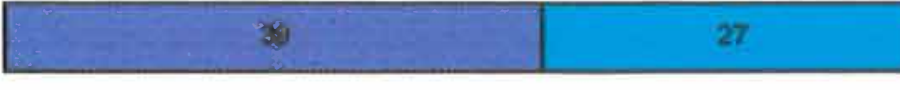

13

14

7

\% areia muito grossa

$\%$ areia grossa

$\square \%$ areia media

a\% areia fina

$\square \%$ areia muito fina

Figura 18 - Fracionamento da areia do perfil P5.

Não é possível evidenciar uma tendência de comportamento das frações de areia em P1 (figura 14). A diminuição nas porcentagens de areia muito grossa e grossa mediante o aumento da profundidade pode ser devido a C2 poder ter recebido um material mais fragmentado ou menos consolidados que as camadas sobrejacentes. 
A distribuição das frações da areia no perfil P2 na área de 15 anos (figura 15) varia irregularmente, predominando as frações de areia muito grossa e grossa sobre as areias médias, finas e muito finas. No entanto em P3 e P4, P5, situados uma área de 32 anos e sobre o mesmo tipo de material de rejeito, pode-se observar maior regularidade na distribuição das frações da areia, sendo que há um sensível aumento das frações de areia média, fina e muito fina nos horizontes superficiais $\mathrm{O}$ e/ou A (figuras 16, 17, e 18, respectivamente). Isso pode ser mais uma evidencia de que as partículas do solo se fragmentam rapidamente, principalmente próximo à superficie do solo (Schafer et al., 1980; Ciolkosz et al., 1985).

\subsection{Características Químicas}

\subsubsection{Fertilidade dos solos da mina}

\section{a) pH, Fósforo e $\mathbf{H}+\mathbf{A l}$}

Os valores de $\mathrm{pH}$, fósforo, teores de e a acidez potencial $(\mathrm{H}+\mathrm{Al})$ encontrados nos solos recentes de mina desenvolvidos sobre os rejeitos da mineração do calcário Irati estão representados na Tabela 2.

Os valores de $\mathrm{pH}$ em água variam entre 6,4 a 7,8 e, de acordo com Catani et al. (1955) citados em Mello et al. (1989), pode-se considerar que a reação destes solos de mina assume um caracter de acidez fraca à alcalinidade fraca, predominando os valores que denotam alcalinidade fraca.

Os valores de $\mathrm{pH}$ do solo obtidos em solução salina de $\mathrm{KCl}$ e de $\mathrm{CaCl}_{2}$ são menores do que os estimados em água e variam entre 5,7 e 7,2 em $\mathrm{CaCl}_{2}$ e 5,8 e 7,1 para $\mathrm{KCl}$. Os menores valores de $\mathrm{pH}$ em solução salina em relação aos valores de $\mathrm{pH}$ em água deve-se ao fato de que os cátions que se dissociam na solução acabam por deslocar os $\mathrm{H}^{+}$ retidos nos sítios de troca da fração coloidal do solo.

A diferença entre o $\mathrm{pH}$ em água e o $\mathrm{pH}$ em $\mathrm{KCl}$ nestes solos de mina é sempre positiva, o que pode indicar a existência de uma pequena reserva de acidez facilmente liberavel e a predominância de CTC sobre a CTA (Quintas-Mosteiro, 1997). 
Tabela 2 - Valores de $\mathrm{pH}$ em água, $\mathrm{KCl}$ e $\mathrm{CaCl}_{2}$, teores de fósforo, e $\mathrm{H}+\mathrm{Al}$ nos solos de mina em formação sobre rejeitos da mineração do calcário da Formação Irati.

\begin{tabular}{|c|c|c|c|c|c|c|c|}
\hline Perfil & Horizonte & $\begin{array}{l}\text { Prof. } \\
\text { (cm) }\end{array}$ & $\mathrm{H}_{2} \mathrm{O}$ & $\begin{array}{c}\mathbf{p H} \\
\mathbf{K C l}\end{array}$ & $\mathrm{CaCl}_{2}$ & $\begin{array}{c}P \\
\mathrm{mg} \mathrm{dm}^{-3}\end{array}$ & $\begin{array}{c}\mathrm{H}+\mathbf{A l} \\
\mathrm{mmol}_{\mathrm{c}} \\
\mathbf{d m}^{-3}\end{array}$ \\
\hline P1 & $\mathbf{A}$ & $0-3$ & 7,3 & 6,5 & 6,8 & 128 & 15 \\
\hline \multirow[t]{2}{*}{ (2 anos) } & C1 & $3-30$ & 7,0 & 5,8 & 6,1 & 46 & 22 \\
\hline & $\mathrm{C2}$ & $30-70$ & 6,8 & 5,9 & 6,2 & 26 & 22 \\
\hline P2 & $\mathbf{0}$ & $3-0$ & 7,4 & 6,9 & 6,8 & 44 & 13 \\
\hline \multirow[t]{3}{*}{ (15 anos) } & C1 & $0-20$ & 7,0 & 6,0 & 5,8 & 51 & 15 \\
\hline & $\mathrm{C2}_{1}$ & $20-40$ & 6,4 & 5,8 & 6,1 & 41 & 22 \\
\hline & $\mathrm{C2}_{2}$ & $40-100$ & 6,9 & 6,3 & 6,0 & 55 & 16 \\
\hline P3 & $\boldsymbol{0}$ & $3-0$ & 6,9 & 6,1 & 5,7 & 38 & 28 \\
\hline \multirow[t]{4}{*}{ (32 anos) } & $\mathbf{A}$ & $0-3$ & 7,6 & 7,0 & 6,1 & 73 & 12 \\
\hline & C1 & $3-20$ & 7,1 & 6,2 & 6,8 & 64 & 12 \\
\hline & $\mathrm{C2}$ & $20-80$ & 7,5 & 6,6 & 6,2 & 150 & 13 \\
\hline & C3 & $80-120$ & 6,8 & 6,4 & 6,5 & 128 & 16 \\
\hline $\mathbf{P 4}$ & $\mathbf{0}$ & $3-0$ & 7,3 & 6,7 & 6,2 & 100 & 18 \\
\hline \multirow[t]{3}{*}{ (32 anos) } & $\mathbf{A}$ & $0-3$ & 7,3 & 6,3 & 7,0 & 111 & 11 \\
\hline & C1 & $3-30$ & 7,3 & 6,6 & 6,3 & 84 & 15 \\
\hline & $\mathrm{C} 2$ & $30-70$ & 7,1 & 6,5 & 6,8 & 38 & 15 \\
\hline P5 & $\mathbf{A}$ & $0-4$ & 7,5 & 6,8 & 6,9 & 144 & 13 \\
\hline \multirow[t]{3}{*}{ (32 anos) } & C1 & $4-50$ & 7,3 & 6,0 & 5,0 & 67 & 16 \\
\hline & $\mathrm{C} 2$ & $50-70$ & 7,8 & 7,1 & 7,2 & 16 & 12 \\
\hline & C3 & $70-100$ & 7,1 & 6,1 & 5,7 & 117 & 16 \\
\hline \multirow{4}{*}{ Rochas } & Siltito alaranj. & - & 6,9 & 6,5 & 6,1 & 168 & 12 \\
\hline & Siltito acinzen. & - & 6,5 & 6,2 & 5,1 & 4 & 18 \\
\hline & Calcário & - & 9,0 & 8,7 & 9,1 & 8 & 5 \\
\hline & Folhelho & - & 7,2 & 6,6 & 6,6 & 4 & 10 \\
\hline
\end{tabular}

Soave (1996) notou que os valores de $\mathrm{pH}$ dos solos de mina por ela analisados apresentaram uma tendência a diminuir com a idade. Isso não fica claro no presente estudo, pois os solos de mina aqui analizados não apresentaram um comportamento que possa ser relacionado a sua idade, ao tipo de vegetação de cobertura ou às profundidades analisadas, variando irregularmente dentro dos perfis.

Para Quintas-Mosteiro (1997), a acidez potencial vem determinada pelo conteúdo de enxofre dos materiais e pela presença de materiais primários que se alteram para combater a acidez gerada. Dessa forma a variação inconstante dos valores de $\mathrm{pH}$ 
destes solos de mina pode estar relacionada à heterogeneidade do material que apresenta predominantemente fragmentos rochosos com diferentes estágios de alteração na fração areia. Assim como em Soave (1996), a predominância de valores de $\mathrm{pH}$ que caracterizam uma reação do solo de alcalinidade fraca pode estar relacionada a presença de fragmentos de rochas calcários.

A acidez potencial $(\mathrm{H}+\mathrm{Al})$ variou de 13 a $28 \mathrm{mmol}_{\mathrm{c}} \mathrm{cm}^{-3}$ nestes solos de mina e pode ser considerada baixa, atingindo seu valor mais elevado na amostra tomada do horizonte $\mathrm{O}$ de $\mathrm{P} 3$ (32 anos).

Embora a acidez potencial tenha apresentado-se mais elevada nos horizontes superficiais nos perfis abertos sobre os montes de 32 anos constituídos unicamente de fragmentos de calcário e folhelhos, não se pode relaciona-la a idade do solo ou tipo de vegetação devido seus valores serem muito variáveis e não apresentarem uma tendência ou uma constância que pudesse ser relacionada à idade do monte ou ao tipo de vegetação.

Os valores de acidez potencial obtidos neste trabalho estão de acordo com os encontrados por Soave (1996) que, em solos da mineração de calcário na região de Rio Claro, encontrou valores de acidez de troca, hidrogênio e alumínio inferiores a 2,5\%, considerando-os como baixos.

A análise de fósforo-resina nas amostras das rochas sãs evidencia que os teores deste elemento é muito elevada no siltito alaranjado $\left(168 \mathrm{mg} \mathrm{dm}^{-3}\right)$, porém esse siltito não é muito comum no volume total de material nos escombros, sendo encontrado alguns fragmentos desta rocha apenas no perfil P1. No entanto, as rochas mais freqüentes em todos os perfis são o calcário+silex e o folhelho pirobetuminoso em diversos estágios de alteração. Estas duas rocha, quando sãs, apresentam baixa disponibilidade deste elemento ( $8 \mathrm{e} 4 \mathrm{mg} \mathrm{dm}^{-3}$, respectivamente). A exposição destas rochas às novas condições de superficie parece favorecer a disponibilidade deste elemento uma vez que teores de $\mathrm{P}$ considerados altos e muito altos são comuns nos bancos de rejeitos.

Os solos de mina aqui estudados apresentaram uma variação nos teores de $\mathrm{P}$ de $16 \mathrm{~g} \mathrm{dm}^{-3}$ a $150 \mathrm{~g} \mathrm{dm}^{-3}$ e levando-se em consideração os limites de classes de teores 
de fósforo extraído do solo pelo método da resina (Raij, 1975, citado por Mello at al., 1989), a maioria dos horizontes destes solos de mina apresentam teores altos e muito altos de $\mathrm{P}$.

Embora alguns autores tenham evidenciado que o incremento do $\mathrm{pH}$ implica no decréscimo da retenção de fosfato pela modificação das cargas nos materiais de cargas variáveis (Barrow, 1984), e pela diminuição da atividade do Al (LopezHernandes \& Burnhan, 1974), não foi possível relacionar os conteúdos de P-resina ao pH no presente estudo.

De acordo com Hsu \& Jackson (1960) a uma faixa de pH entre 6 e 7, a solubilidade dos fosfatos de ferro, de alumínio e de cálcio são iguais, mas à valores de $\mathrm{pH}$ superiores a 7 os carbonatos de cálcio apresentam maior estabilidade que os de ferro (Cho \& Caldwell, 1959 e Hsu \& Jackson 1960).

No presente estudo foi observado que valores de $\mathrm{pH}$ superiores a 7 são comuns nestes solos de mina, então era de se esperar uma maior retenção do fosfato pois altos valores de $\mathrm{pH}$ aliado à altos conteúdos de carbonato podem reduzir a solubilidade do fosfato uma vez que a presença de íons alcalinos originam compostos de baixa solubilidade com os íons $\mathrm{PO}_{4}^{-3}$ (Roberts et al., 1988 (c) e Monterroso-Martinez, 1995, respectivamente).

O fosfato pode reagir com carbonatos formando precipitados de fosfato dicálcico (Cole et al., 1953) e, na superficie da calcita, pode formar-se além do fosfato dicálcico, e octocálcico (Freeman \& Rowell, 1981), cristais de apatita (Holford \& Mattingly, 1975) e de brushita (Wang \& Tzou , 1995).

No presente estudo foi evidenciado um mineral que contem $\mathrm{P}$ e Ca em sua constituicão e tal mineral pode ser evidenciado pela micrografia 2D (página 132) e seu referente pico espectral 77D (página 133) de fosfato nas amostras destes solos analisadas no microscópio eletrônico de verredura.

$O$ fosfato pode ainda estar formar complexos de $\mathrm{P}-\mathrm{Ca}$ que são posteriormente ligados as argilas, podendo vir a ser disponível em solução levemente ácida (Ellis \& Troug, 1955). 
Com relação à idade dos solos de mina, apesar de vários autores terem observado que a adsorção e fixação do $\mathrm{P}$ por óxidos de ferro é favorecida pelo incremento do tempo de exposição do rejeito devido à oxidação do material exposto e formação de complexos Fe-P (Pulford \& Duncan, 1975, Howard et al., 1988, Roberts et al., 1988 a e b, respectivamente), não foi evidenciado aumento da fixação de fosfato com o avanço da idade dos solos de mina aqui estudados.

Levando-se em consideração perfis constituídos de um mesmo material (mescla de fragmentos rochosos de calcário + sílex e folhelhos pirobetuminosos) como é o caso de P2 (15 anos) e P3, P4 e P5 (32 anos de exposição, com P5 revegetado a 7 anos), pode-se notar que os perfis mais velhos, com 32 anos de exposição, apresentaram teores de P-resina frequentemente mais elevados em relação ao perfil mais novo (15 anos). Soave (1996) também evidenciou que a maior disponibilidade de $\mathrm{P}$ coincide com a área mais velha por ela estudada, onde o intemperismo dos rejeitos são acelerados pelos efeitos da vegetação. Além disso, a complexação de cátions livres pela matéria orgânica pode favorecer um aumento do $\mathrm{P}$ extraível com a idade do solo de mina (Trasar-Cepeda et al., 1993) e, de acordo com Ellis \& Troug (1955), um alto grau de saturação de Ca na montmorilonita irá prevenir a fixação de fósforo pelo ferro ou alumínio.

\section{b) Carbono Total e carbono orgânico}

Para se quantificar o carbono total presente nos solos de mina utilizou-se do método de combustão seca. Por este método é possivel ter uma idéia do carbono retido na matéria orgânica na forma de tecidos vivos ou restos animais e vegetais, como também o carbono contido nos produtos finais da decomposição da matéria orgânica, além do carbono fóssil presentes nos folhelhos carbonosos pirobetuminosos e os dos carbonatos.

Os resultados da estimativa de carbono total e orgânico estão representados nas figuras 19 a 29. Os dois métodos indicam que ocorre maior quantidade de carbono na superficie dos perfis, ficando claro a ocorrência de um aporte superficial de matéria orgânica. 
Numa comparação entre os valores de carbono total e orgânico, pode-se observar que os maiores valores de carbono foram obtidos através da combustão seca que estima tanto o carbono orgânico, como o inorgânico.

A figura 19 mostra os valore de carbono total e orgânico das principais rochas constituintes dos rejeitos da mineração do calcário Irati. $\mathrm{O}$ folhelho é a rocha que possui maior quantidade de carbono orgânico e total.

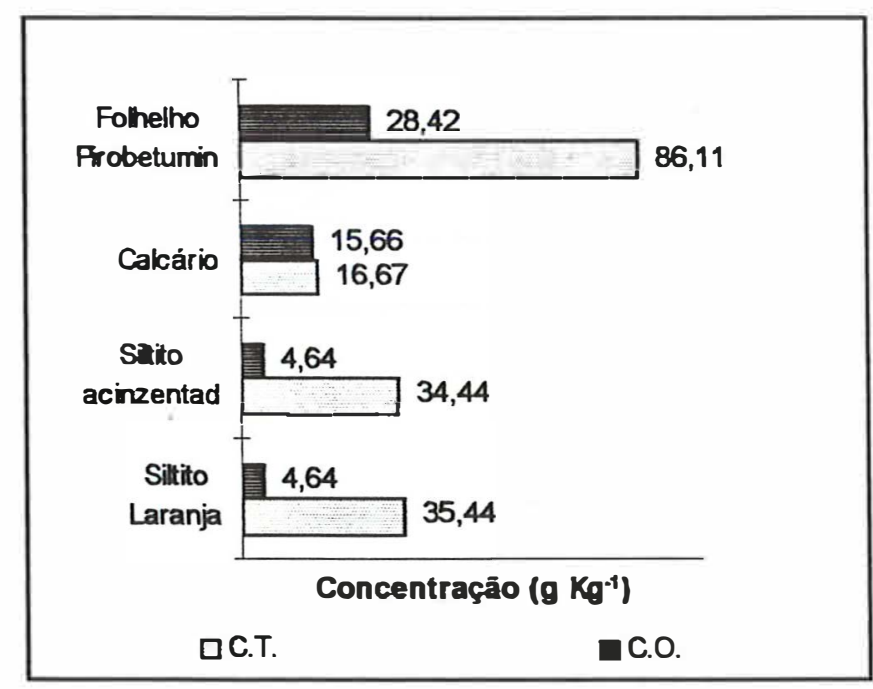

Figura 19 - Carbono total estimado pela combustão seca e carbono orgânico estimado pelo método colorimétrico em diferentes amostras de rochas constituintes do rejeito da mineração de calcário.

\section{b.1) Carbono total}

O carbono total inclui o carbono orgânico passivel de oxidações inerentes a tecidos vegetais e animais que se encontram no solo, como também o carbono na forma estável como o húmus e o carbono fóssil presente nos fragmentos das rochas sedimentares constituintes do rejeito.

O perfil P1 (2 anos) apresenta as menores concentrações de carbono total, tanto em superficie como nos horizontes subjacentes. Os teores de carbono total variam de $82,8 \mathrm{~g} \mathrm{Kg}^{-1}$, na superficie, a $36,7 \mathrm{~g} \mathrm{Kg}^{-1}$ na camada C2 (figura 20).

O perfil P2 (15 anos), atingiu um teor de carbono total de $131,8 \mathrm{~g} \mathrm{Kg}^{-1} \mathrm{em}$ superficie que decresce com o aumento da profundidade, atingindo $90 \mathrm{~g} \mathrm{Kg}^{-1}$ na camada C2.2 a uma profundidade de 60 a $100 \mathrm{~cm}$ (figura 21). 


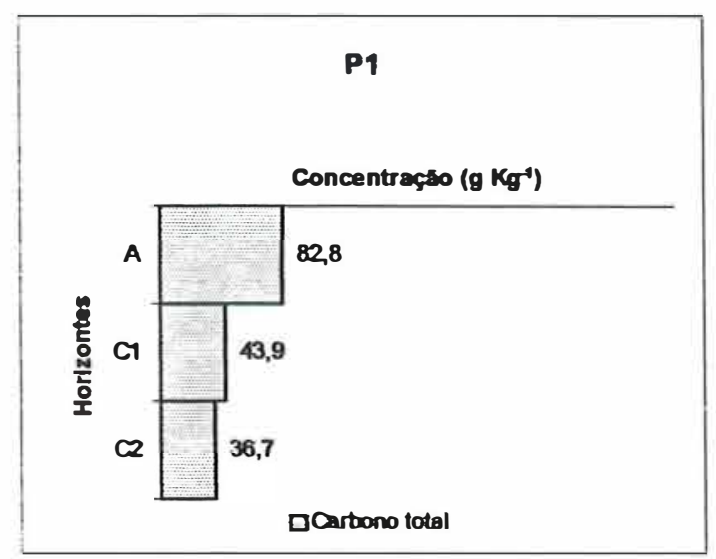

Figura 20 - Carbono total no perfil P1 (2 anos), aberto em área de deposição de rejeitos constituídos de mistura de materiais rochosos e argilosos, sobre cobertura de vegetação de transição (gramíneas/ leucena).

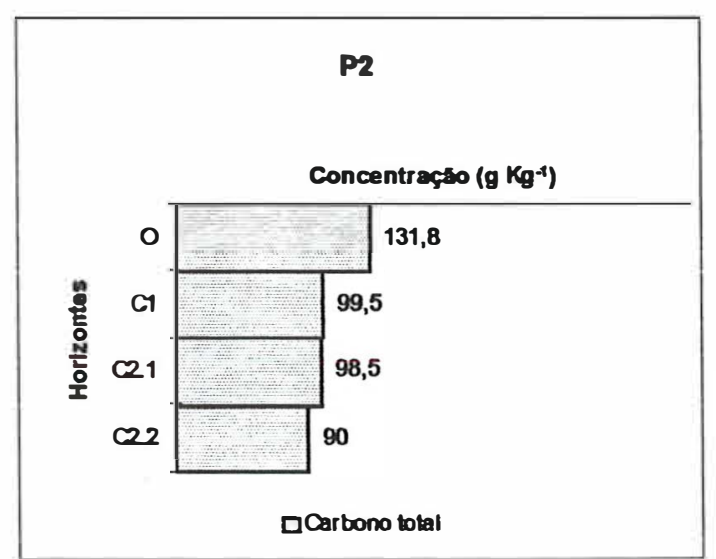

Figura 21 - Carbono total no perfil P2 (15 anos), aberto em área de deposição de rejeitos constituídos fragmentos rochosos sobrecobertura de leucenas.

A maior concentração de carbono orgânico em superficie é encontrada no perfil P3 (32 anos, sobre cobertura vegetal constituída por leucena). Este perfil possui um horizonte $\mathrm{O}$ distinto em sua superficie com poucos indícios de pedoturbações e que contem 311,7 $\mathrm{g} \mathrm{Kg}^{-1}$ de carbono orgânico (figura 22). De acordo com Schafer et al. (1980), um pobre contato com o solo e um secamento rápido, o que colabora para o retardamento da decomposição da liteira em solos de mina.

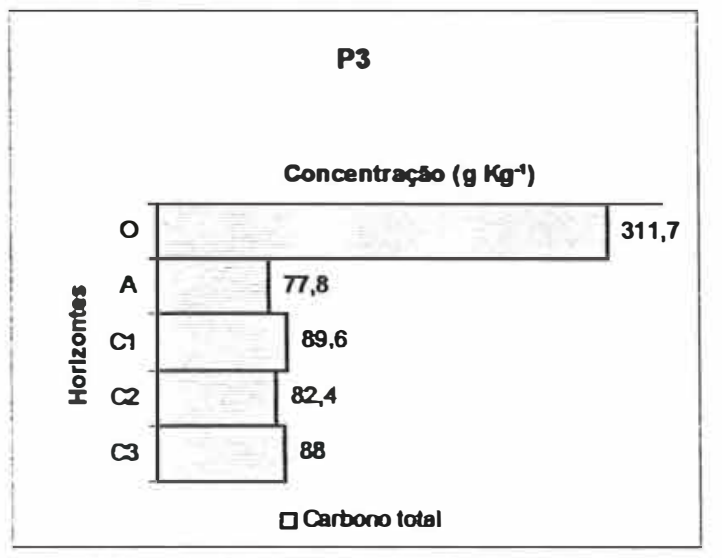

Figura 22 - Carbono total no perfil P3 (32 anos), aberto em área de deposição de rejeitos constituídos de fragmentos rochosos sobre cobertura de leucenas.

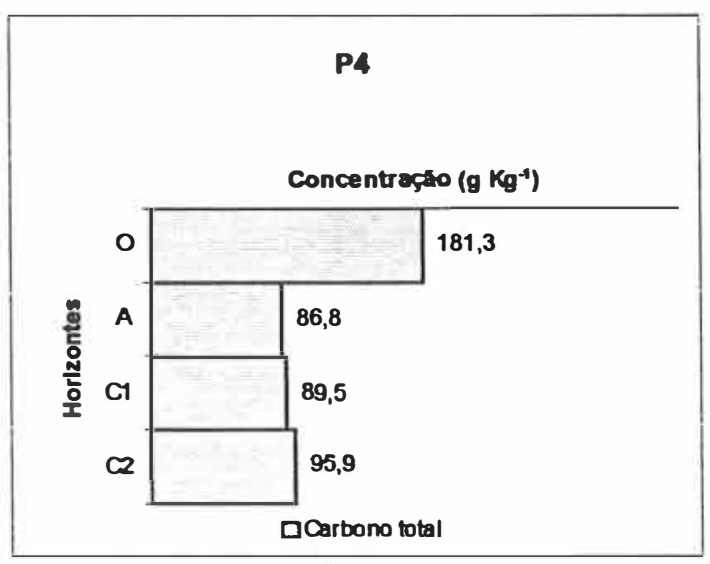

Figura 23 - Carbono total no perfil P4 (32 anos), aberto em área de deposição de rejeitos constituídos de fragmentos rochosos sobre cobertura de leucenas. 
Sobre a mesma área de P3 e sobre o mesmo tipo de cobertura vegetal, o perfil P4 (figura 23) apresenta uma menor quantidade de carbono total na superficie $\left(181,3 \mathrm{~g} \mathrm{Kg}^{-1}\right)$. Isso pode estar relacionada às freqüentes pedoturbações encontradas neste perfil, o que poderia estar causando a mescla do material orgânico acumulado na superficie ao material mineral de subsuperficie.

Organismos do solo podem incorporar material orgânico em profundidade e trazer material mineral à superficie dos solos (Throp (1949) citado por Thomas \& Jansen (1985)), promovendo a pedoturbação e homogeneização do solo (Hole, 1961; Mandel \& Sorenson, 1982).

$\mathrm{O}$ perfil P5, embora aberto em uma área com 32 anos de deposição, sofreu um nivelamento da superficie por em 1992 para a implantação de pastagem. Essa operação provavelmente provocou o arraste dos horizontes superficiais que vinham se formando. Portanto o aporte de carbono total em P5 se dá em apenas 5 anos e apesar de não ser possível se distinguir um horizonte $O$, esse perfil apresenta um horizonte A com $119,9 \mathrm{~g} \mathrm{~kg}^{-1}$ de carbono total (figura 24).

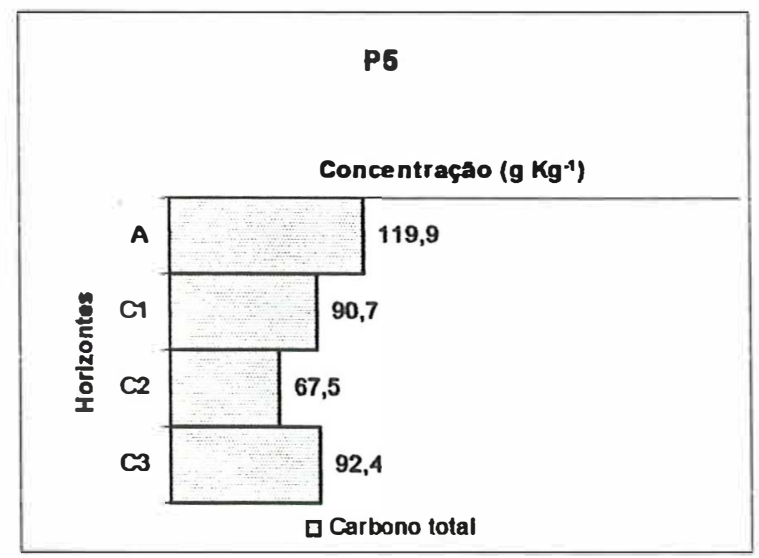

Figura 24- Carbono total no perfil P5 (32 anos), aberto em área de deposição de rejeitos constituídos de fragmentos rochosos sobre cobertur de pastagem consorciada (gramminea/leucena). 
O horizonte C2 do perfil P5 apresenta a menor concentração de carbono total. Isso reflete a resistência oferecida por este horizonte ao crescimento radicular. Este horizonte é mais adensado e com maior teor de argila que os demais neste perfil.

\section{b.2) Carbono orgânico}

Através dos dados de carbono orgânico, apresentados nas figuras 25 a 29, é possível se observar o aporte de carbono orgânico na superficie destes solos de mina com o tempo de deposição de rejeito, bem como a influência do tipo de cobertura vegetal e também do tempo de deposição dos montes. De acordo com Quintas-Mosteiro (1997), a acumulação de carbono orgânico dá uma idéia da evolução edáfica dos solos de mina.

$\mathrm{O}$ efeito do tempo sobre o aporte de material orgânico em solos de mina foi observado por vários autores (Schafer et al., 1980; Roberts et al., 1988 a e b, Chichester \& Hauser, 1991, Soave, 1996) e também pode ser evidenciado neste trabalho comparando-se os niveis de carbono orgânico estimados para os perfis P1 (2 anos), P2 (15 anos), P3 e P4 (32 anos), onde há um aumento da concentração de carbono total e orgânico com o aumento da idade do monte de rejeito.

O perfil P1 (2 anos) apresenta as menores concentrações de carbono orgânico em relação aos montes mais velhos, tanto em superficie como nos horizontes subjacentes mas, apesar de menores perante os demais perfis, estes teores podem ser considerados altos nos horizonte $\mathrm{A}$ e na camada $\mathrm{C} 1$ e médio na camada $\mathrm{C} 2$ (figura 25) de acordo com de Catani e Jacinto (1974), citados em Mello et al. (1989).

$\mathrm{O}$ perfil P2 (15 anos), atingiu um teor de carbono total de $42,3 \mathrm{~g} \mathrm{Kg}^{-1} \mathrm{em}$ superficie que decresce com o aumento da profundidade, atingindo $23,2 \mathrm{~g} \mathrm{Kg}^{-1}$ a uma profundidade de 60 a $100 \mathrm{~cm}$ (figura 26). $O$ rápido acúmulo de matéria orgânica durante os primeiros anos de evolução é considerado como um típico processo edáfico de solos de mina Varela et al. (1993).

Os perfis $\mathrm{P} 3$ e P4, ambos na área de 32 anos e sobre cobertura de leucena, apresentaram maiores concentrações de carbono orgânico (figuras 27e 28). 


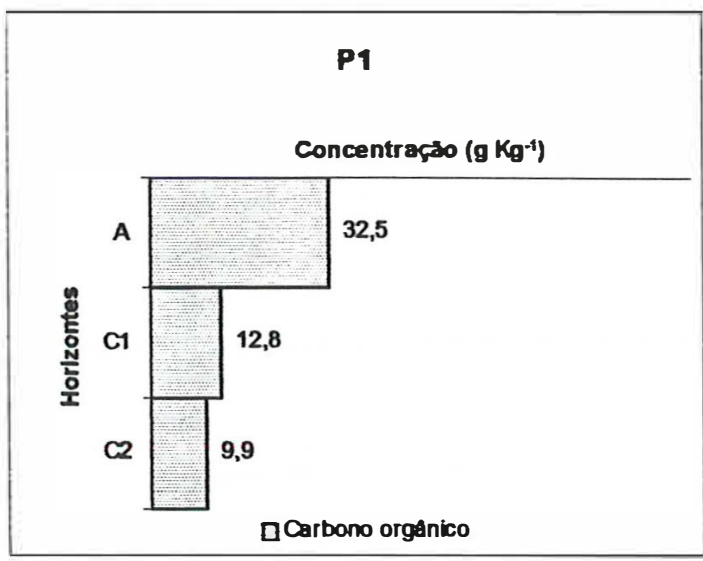

Figura 25 - Carbono orgânico no perfil P1 (2 anos), aberto em área de deposição de rejeitos constituídos da mescla material argiloso e rochoso, sobre cobertura vegetal de transição (gramineas/leucenas).

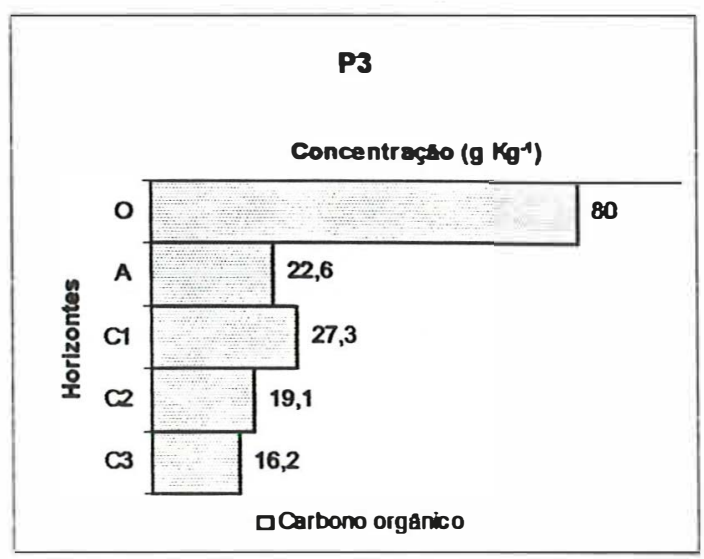

Figura 27 - Carbono orgânico no perfil P3 (32 anos), aberto em área de deposição de rejeitos constituídos de fragmentos rochosos, sobre cobertura leucena.

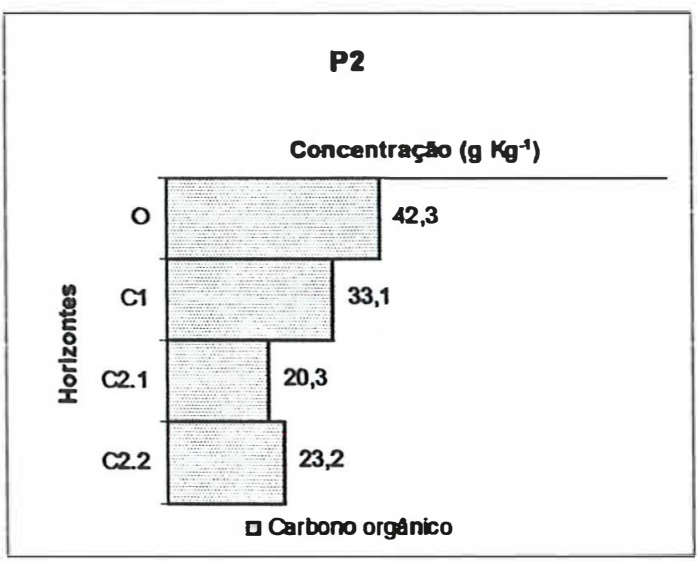

Figura 26 - Carbono orgânico no perfil P2 (15 anos), aberto em área de deposição de rejeitos constituídos de fragmentos rochosos, sobre cobertura vegetal de leucenas.

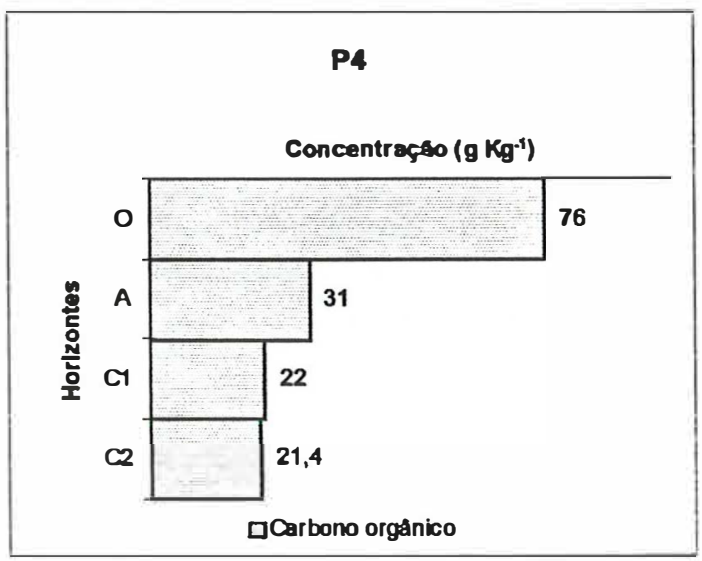

Figura 28 - Carbono orgânico no perfil P4 (32 anos), aberto em área de deposição de rejeitos constituídos de fragmentos rochosos, sobre cobertura leucena.

Além da idade do solo de mina, a influência da vegetação sobre o carbono em superficie pode ser evidenciada principalmente na superficie destes solos de mina.

Observando-se os teores de carbono total alcançados na superficie de P1 (2 anos) e de P5 (32 anos, porém com 5 anos de revegetação) ambas sobre cobertura vegetal composta por gramíneas e leucena (figuras 25 e 29 , respectivamente) e comparando-se estes teores aos obtidos na superficie de P2, em área de 15 anos de 
deposição e sobre vegetação arbustiva constituída unicamente por leucenas (figura 26), pode-se notar que ocorre uma rápida acumulação de carbono orgânico em superficie nas áreas sobre vegetação mista de gramíneas e leucena $\left(32,5 \mathrm{~g} \mathrm{Kg}^{-1}\right.$ e $41,2 \mathrm{~g} \mathrm{Kg}^{-1} \mathrm{em} \mathrm{P1} \mathrm{e}$ P2, respectivamente), tanto que os teores chegam a ser próximos ao encontrado na superficie da área de 15 anos $\left(42,2 \mathrm{~g} \mathrm{Kg}^{-1} \mathrm{em} \mathrm{P} 2\right)$.

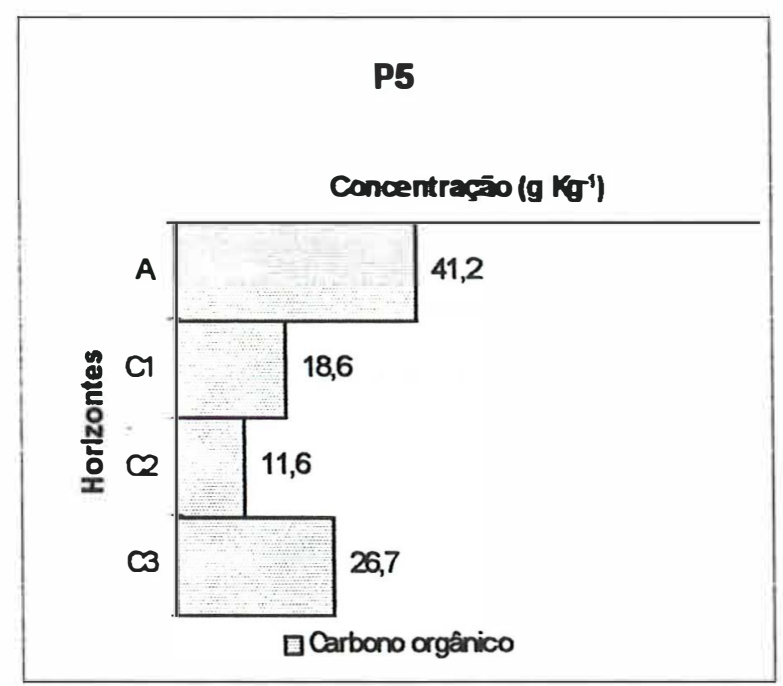

Figura 29 - Carbono orgânico no perfil P5 (32 anos), aberto em área de deposição de rejeitos constituídos de fragmentos rochosos, sobre cobertura de pastagem consorciada (gramineas/leucena).

Estes resultados podem estar relacionados ao tipo de vegetação existentes sobre estas áreas, onde dominam gramíneas e leguminosas nas primeiras (P1 e P5) e vegetação arbustivo-arbórea na última (P2), onde, de acordo com Soave (1996), o acúmulo e a ciclagem da matéria orgânica corresponde a um período mais longo.

As gramíneas possuem altas taxas de renovação de raízes (Dahlman \& Kucera, 1965) e esse fato pode explicar o rápido aporte de material orgânico na superficie encontrada em P1 e em P5, uma vez que as áreas onde foram abertos estes perfis apresentam-se cobertas por gramíneas com leucena. 


\section{c) Nitrogênio}

As figuras 30 a 36 ilustram o comportamento do nitrogênio de acordo com a profundidade dos solos de mina e o aporte deste elemento perante o tempo de exposição do rejeito à revegetação.

O nitrogênio total apresenta maiores concentrações na superficie de todos os perfis, assumindo valores considerados altos para solos do Estado de São Paulo (Catanii et al., 1955, citado por Mello et al., 1989). Pode-se observar também uma tendência de diminuição de seus valores de concentração com o aumento da profundidade do solo de mina, onde frequentemente encontram-se teores considerados médios, principalmente em camadas mais profundas.

A rápida acumulação de nitrogênio na superficie destes solos é clara quando se observa os teores de N no perfil P1 (2 anos), que apresenta um horizonte A com um teor de $\mathrm{N}$ cerca de 3 vezes maior que os encontrados nas camadas subjacentes $\mathrm{C} 1$ e C2 (figura 30).

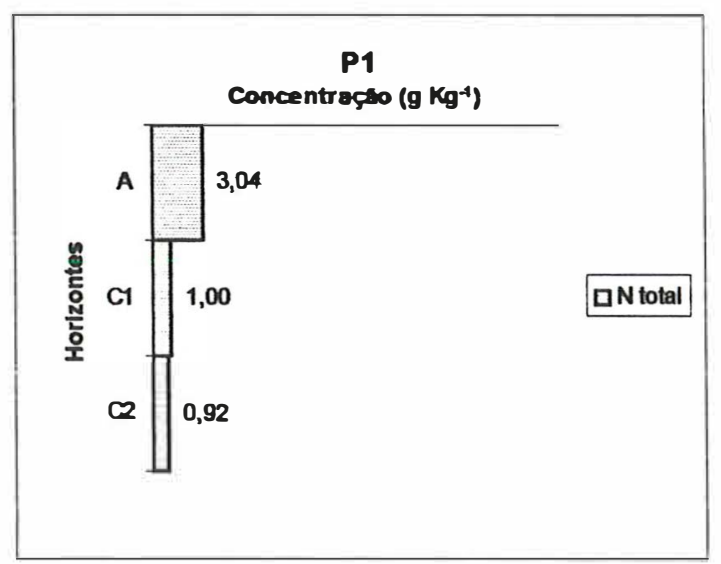

Figura 30 - Nitrogênio no perfil Pl (2 anos), aberto em área de deposição de rejeitos constituídos da mescla de materiais argilosos e rochosos, sobre cobertura vegetal de transição (gramineas/leucenas).

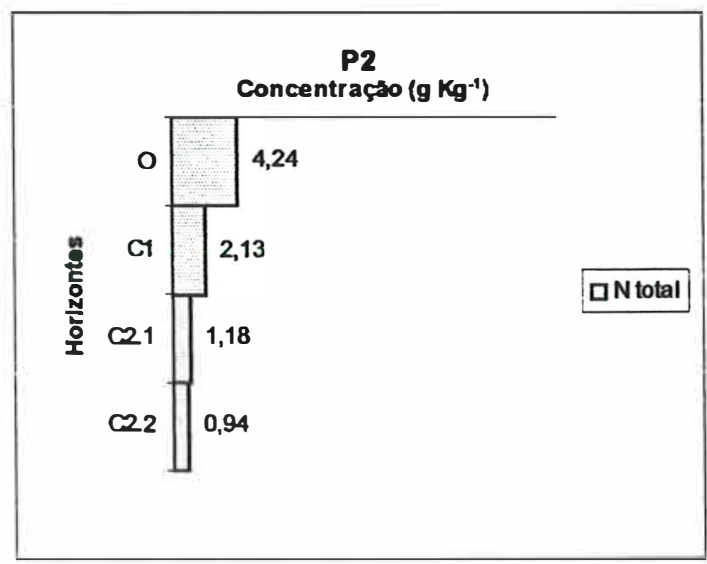

Figura 31 - Nitrogênio no perfil P2 (15 anos), aberto em área de deposição de rejeitos constituídos de fragmentos rochosos, sobre cobertura vegetal de leucenas.

O tempo de exposição dos montes de rejeito pode influenciar no aporte de nitrogênio. Assim como observado por Varela et al. (1993), ocorre um rápido aporte de 
$\mathrm{N}$ nestes solos de mina e isso pode ser constatado observando-se principalmente os horizontes superficiais P1 (2 anos), P2 (15 anos), P3 e P4 (32 anos).

Os perfis P1 (2 anos) e P2 (15 anos) apresentam as menores concentrações de $\mathrm{N}$ total em superficie $\left(3,04 \mathrm{~g} \mathrm{Kg}^{-1}\right.$ e $4,24 \mathrm{~g} \mathrm{Kg}^{-1}$, figuras 30 e 31, respectivamente) enquanto que os máiores teores de $\mathrm{N}$ total se encontram na superficie de P3 e P4 (19,4 $\mathrm{g} \mathrm{Kg}^{-1}$ e $12,35 \mathrm{~g} \mathrm{Kg}^{-1}$, figuras 32 e 33, respectivamente), abertos nas áreas mais velhas.

$\mathrm{O}$ rápido aporte da concentração de $\mathrm{N}$ pode estar relacionado ao aumento da atividade biológica com a idade do solo (Johnson et al.,1982), à água da chuva e, principalmente, à fixação biológica por leguminosas (Roberts et al., 1981; Skeffington \& Bradshaw, 1881; Jefferies et al, 1981; Soave, 1996).

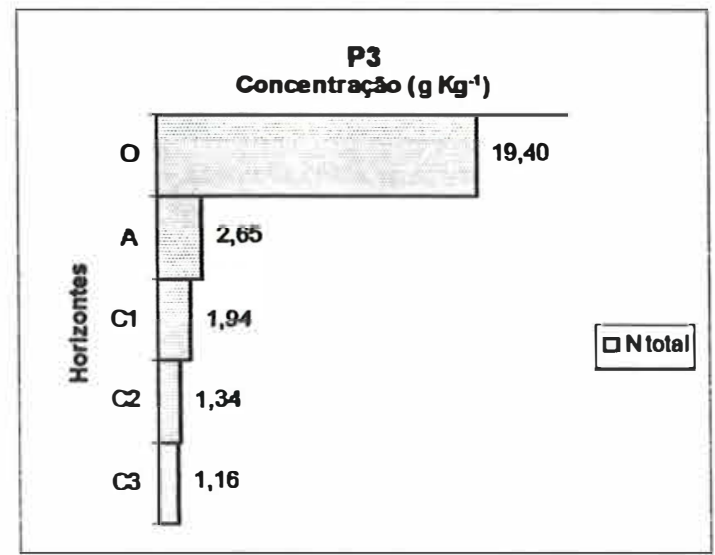

Figura 32 - Nitrogênio no perfil P3 (32 anos), aberto em área de deposição de rejeitos constituídos de fragmentos rochosos, sobre cobertura leucena.

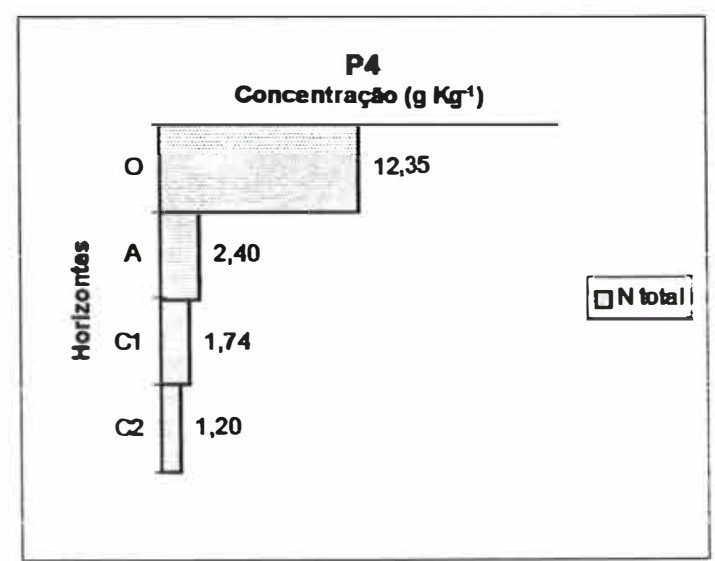

Figura 33 - Nitrogênio no perfil P4 (32 anos), aberto em área de deposição de rejeitos constituídos de fragmentos rochosos, sobre cobertura leucena.

O perfil P5, apesar de se encontrar em uma área de 32 anos, sofreu uma operação de nivelamento do terreno a 5 anos, o que provocou um arraste de sua camada superficial, criando-se posteriormente uma cobertura vegetal constituída de gramíneas e leucena para pastagem. Portanto pode-se considerar que P5 possui 5 anos de revegetação, apresentando uma concentração de $\mathrm{N}$ total em superficie de $5,28 \mathrm{~g} \mathrm{Kg}^{-1}$ (figura 34). 
Assim como ocorre com o carbono orgânico, pode-se notar o rápido aporte de nitrogênio observando-se os perfis P1 (2 anos), e P5 (na área de 32 anos, porém com apenas 5 anos de revegetação), apresentaram teores de $\mathrm{N}$ total relativamente próximos ao encontrado na superficie do perfil P2 (15 anos).

A menor concentração de $\mathrm{N}$ encontra-se na camada $\mathrm{C} 2$ do perfil $\mathrm{P} 5$ (figura 34). Esta camada possui maior teor de argila e silte e se encontra mais adensada que as demais (Anexo Al.5 na página 158).

As rochas sedimentares também podem conter nitrogênio e contribuir para no fornecimento deste elemento às plantas, principalmente nos estágios iniciais da recuperação de uma área degradada (Power et al., 1974).

Conteúdos que variam entre $1 \mathrm{~g} \mathrm{Kg}^{-1}$ a $8 \mathrm{~g} \mathrm{Kg}^{-1}$ de $\mathrm{N}$ foram encontrados por Krechetova (1996) em folhelhos betuminosos de formação marinha. Mas parte deste $\mathrm{N}$ pode estar retido como íon amônio nas intercamadas estruturais dos minerais de argila (Stevenson, 1959), ou ainda pode estar biologicamente ativo na forma de $\mathrm{NH}_{4}{ }^{+}$nos sítios de troca das argilas (Power et al., 1974), além de formas orgânicas como os aminoácidos (Reeder \& Berg, 1977; Krechetova, 1996).

Dentre as rochas colhidas no corte da frente de lavra, a maior concentração de $\mathrm{N}$ total foi encontrada no folhelho pirobetuminoso. Esse material apresentou $1,08 \mathrm{~g} \mathrm{Kg}^{-1}$ de $\mathrm{N}$ total (figura 35).

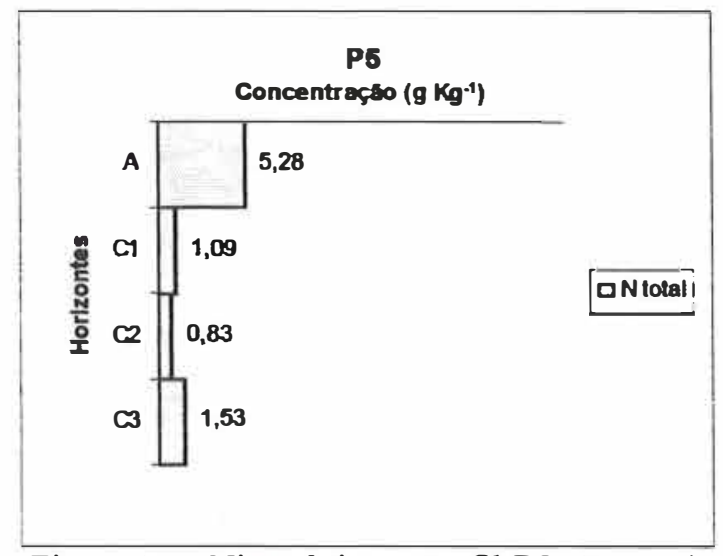

Figura 34 - Nitrogênio no perfil P5 (32 anos), aberto em área de deposição de rejeitos constituídos de fragmentos rochosos

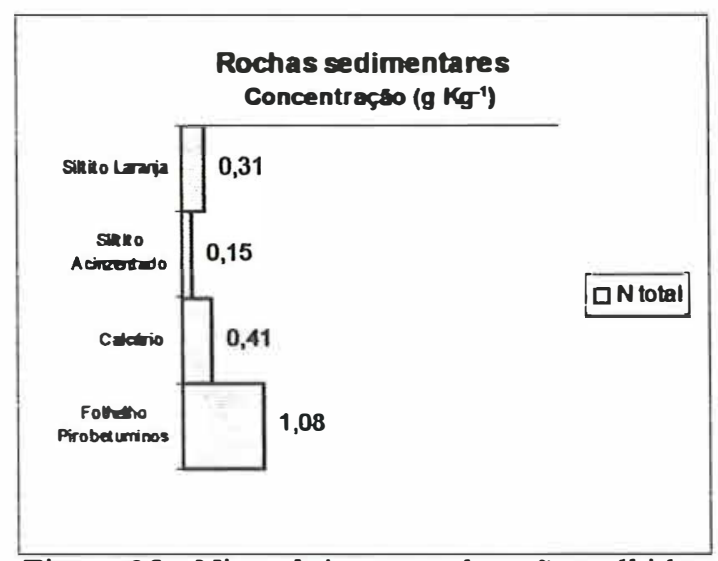

Figura 35 - Nitrogênio nas rochas sãs, colhidas na frentes de lavra da mineração do calcário da formação Irati. 
$\mathrm{O} \mathrm{NH}_{4}{ }^{+}$trocável presentes em rochas sedimentares pode sofrer rápida nitrificação quando exposto às condições de superfície, resultando no aumento de $\mathrm{NO}_{3}{ }^{-}$ no ambiente. Portanto deve-se atentar para o manejo adequado do material de rejeito que contém nitrogênio na forma biologicamente ativa, pois tanto ele pode favorecer o estabelecimento de uma cobertura vegetal nos primeiros anos de recuperação, como também, pode causar a contaminação da água de superfície ou o lençol freático (Power et al. 1974).

\section{d) Relação $\mathrm{C} / \mathrm{N}$}

Os valores da relação $\mathrm{C} / \mathrm{N}$ estimados neste trabalho são muito variáveis. Observa-se em superficie um valor mínimo de 4,12 em P3 (32 anos) e um valor máximo de 10,69 em P1 (2 anos).

Há uma tendência de incremento da relação $\mathrm{C} / \mathrm{N}$ com o aumento da profundidade no perfil. Nas camadas mais profundas pode-se evidenciar que os valores da relação $\mathrm{C} / \mathrm{N}$ variam de 10,73 em P1 (2 anos) a 24,68 em P2 (32 anos). Devido a grande variabilidade dos valores da relação $\mathrm{C} / \mathrm{N}$, estes resultados não estão de acordo com Soave (1996) que apresenta valores da relação $\mathrm{C} / \mathrm{N}$ mais constantes, próximos de 11 ou 12.

A relação $\mathrm{C} / \mathrm{N}$ é próxima do ideal nos horizontes superficiais dos perfis $\mathrm{P} 1$ (figura 36) e P2, (figura 37) com 2 e 15 anos respectivamente. No entanto P2 sofre um acentuado aumento de $\mathrm{C} / \mathrm{N}$ com o aumento da profundidade pois, embora ambas concentração de C.O. e $\mathrm{N}$ total apresentaram uma tendência de decrescer com a profundidade, o nitrogênio sofre um decréscimo mais drástico com o aumento da profundidade em relação ao carbono, o que implica num aumento da relação $\mathrm{C} / \mathrm{N}$. 


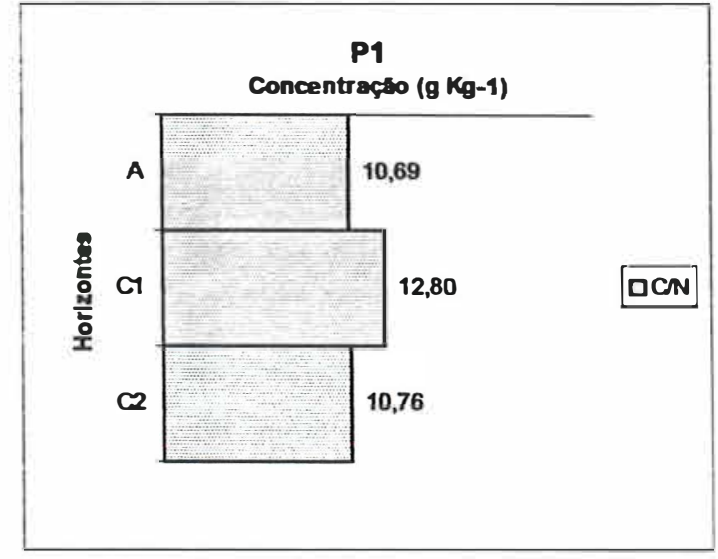

Figura 36 - Relação C/N no perfil Pl (2 anos), aberto em área de deposição de rejeitos constituídos da mescla de fragmentos rochosos e blocos argilosos, sobre cobertura vegetal de transição (gramineas/leucenas).

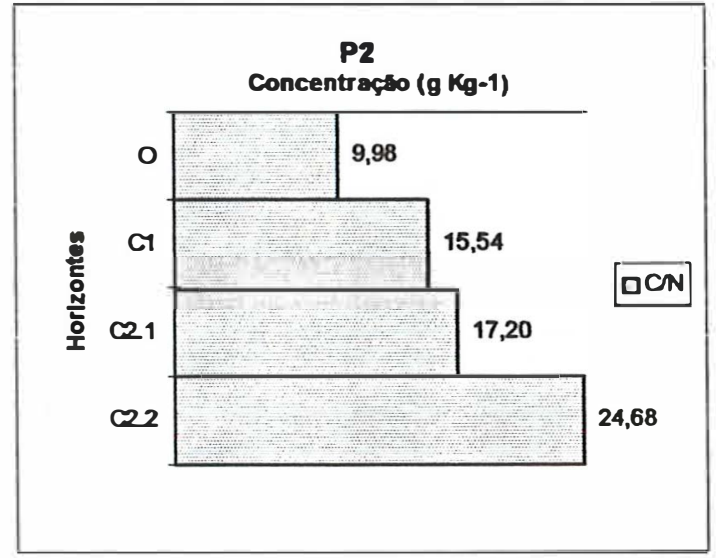

Figura 37 - Relação $\mathrm{C} / \mathrm{N}$ no perfil no perfil P2 (15 anos), aberto em área de deposição de rejeitos constituídos de fragmentos rochosos, sobre cobertura vegetal de leucenas.

Os perfis P3 e P4, sobre vegetação de leucena, embora apresentarem um alto conteúdo de carbono orgânico em superficie, contem maiores teores de $\mathrm{N}$ total, $\mathrm{O}$ que provavelmente leva a uma redução da relação $\mathrm{C} / \mathrm{N}$ nestes horizontes orgânicos.

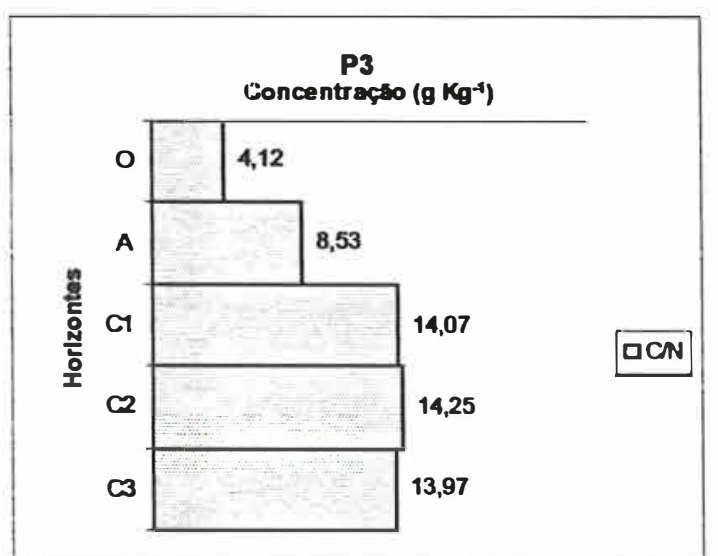

Figura 38 - Relação C/N no perfil no perfil P3 (32 anos), aberto em área de deposição de rejeitos constituídos de fragmentos rochosos e sobre cobertura leucena.

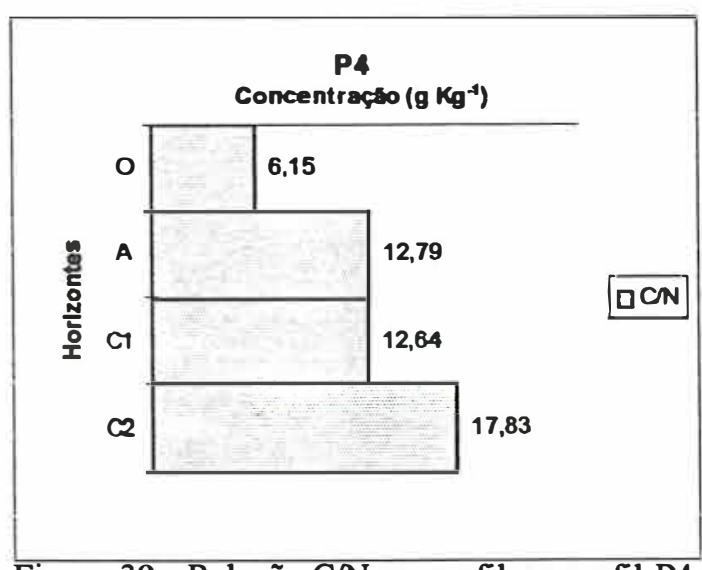

Figura 39 - Relação C/N no perfil no perfil P4 (32 anos), aberto em área de deposição de rejeitos constituídos de fragmentos rochosos, sobre cobertura leucena. 
$\mathrm{O}$ perfis $\mathrm{P} 3$ (figura 38 ) apresentou um horizonte $\mathrm{A}$ com relação $\mathrm{C} / \mathrm{N}$ de 8,53. Apesar do teor de $\mathrm{N}$ total decrescer consideravelmente neste horizonte, ele foi acompanhado do decréscimo de C.O.

Sobre a mesma área e o mesmo tipo de vegetação de cobertura, o perfil P4 (figura 39) apresentou um horizonte $\mathrm{A}$ com uma relação $\mathrm{C} / \mathrm{N}$ de 12,76 , o que reflete maior concentração de carbono nesse horizonte, em relação ao horizonte A de P3. Isso pode ser devido a maior pedoturbação encontrada em P4.

Concordando com Varela et al. (1993), que observaram um decréscimo da relação $\mathrm{C} / \mathrm{N}$ com o aumento da idade dos solos de mina, no presente trabalho se constatou uma tendência em diminuição dos valores de $\mathrm{C} / \mathrm{N}$ nos perfis mais antigos. Isso pode ser observado comparando-se os perfis P2 (15 anos), P3 e P4 (32 anos), abertos em rejeitos formados basicamente por fragmentos material rochosos representados por folhelhos pirobetuminosos e calcários com sílex. Nota-se nestes perfis rochosos, uma tendência em redução da relação $\mathrm{C} / \mathrm{N}$ com o aumento da idade do monte e fica melhor evidenciado nas camadas mais profundas destes perfis, onde o perfil mais recente (P2) teve menor teor de nitrogênio e maior concentração de carbono em relação aos demais, o que acarretou numa maior relação $\mathrm{C} / \mathrm{N}\left(24,68 \mathrm{~g} \mathrm{Kg}^{-1}\right)$.

Em P5, apesar da vegetação ser relativamente nova, implantada em 1992, a relação $\mathrm{C} / \mathrm{N}$ foi baixa devido ao pouco acúmulo de material orgânico (figura 40).

Comparando-se P1, na área de 2 anos sobre vegetação de transição gramínea/leucena e P5 na área de 32 anos sobre um sistema de pastagem consorciada de gramíneas e leucena implantado há 6 anos, pode-se notar o rápido acúmulo de carbono e nitrogênio já em dois anos de deposição. 


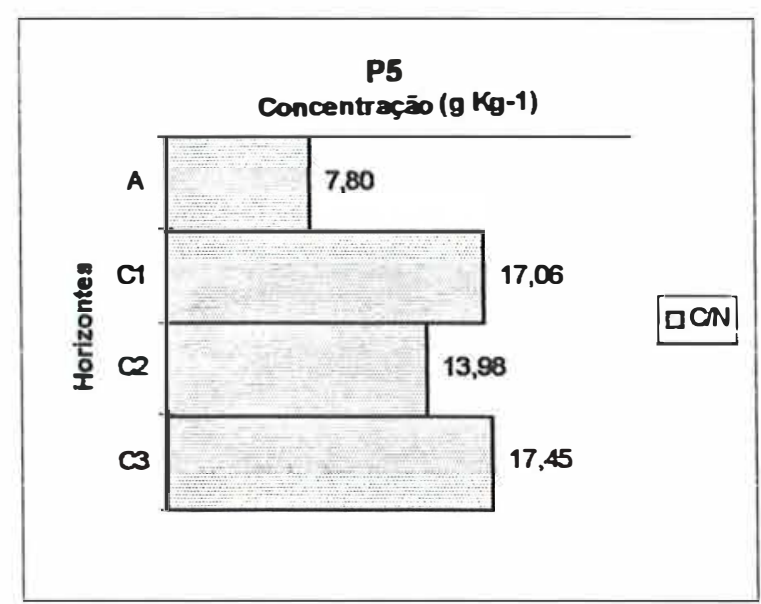

Figura 40 - Relação C/N no perfil P5 (32 anos), aberto em área de deposição de rejeitos constituídos de fragmentos rochosos, sobre cobertura de pastagem consociada (gramineas/leucena).

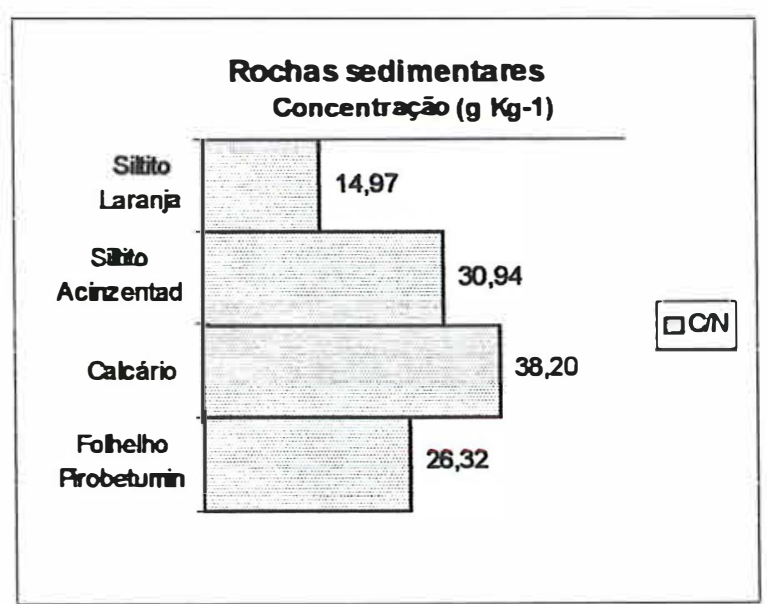

Figura 41 - Relação $\mathrm{C} / \mathrm{N}$ nas rochas sãs,coletadas na frentes de lavra da mineração do calcário da formação Irati.

Entre as rochas constituintes do rejeito, o folhelho pirobetuminoso possui os maior conteúdo de carbono orgânico e nitrogênio total apresentando, porém o menor valor da relação $\mathrm{C} / \mathrm{N}$ se encontrou no siltito laranja, pois essa rocha, juntamente siltito acinzentado, apresentou menores quantidades de carbono orgânico (figura 41).

\section{e) Enxofre}

Dentre as rochas analisadas, o folhelho pirobetuminoso é a rocha que apresenta maior concentração de $\mathrm{S}_{-} \mathrm{SO}_{4}$ (figura 42), uma vez que o rejeito da mineração do calcário Irati contém pirita (Soave, 1996). Além da pirita, o enxofre ainda pode estar presente no ácido húmico dos folhelhos betuminosos como os encontrados por Krechetova (1996).

$\mathrm{O}$ perfil $\mathrm{P} 1$, na área de dois anos de idade, apresenta menores valores de concentração de $\mathrm{S}_{-} \mathrm{SO}_{4}$ ao longo da profundidade do perfil, variando de 45 a $88 \mathrm{mg} \mathrm{dm}^{-3}$. Isso pode ser devido à constituição do rejeito nesta área, que apresenta menores quantidades de folhelho pirobetuminosos em relação aos demais perfis mais rochosos. 
Apesar de recente (apenas 2 anos), pode-se notar em Pl a tendência em perda de $\mathrm{S}^{-S}{ }_{4}$ na superficie deste solo. De acordo com Doolittle et al. (1993), a oxidação da pirita fica evidente pela elevada concentração de sulfato na solução.

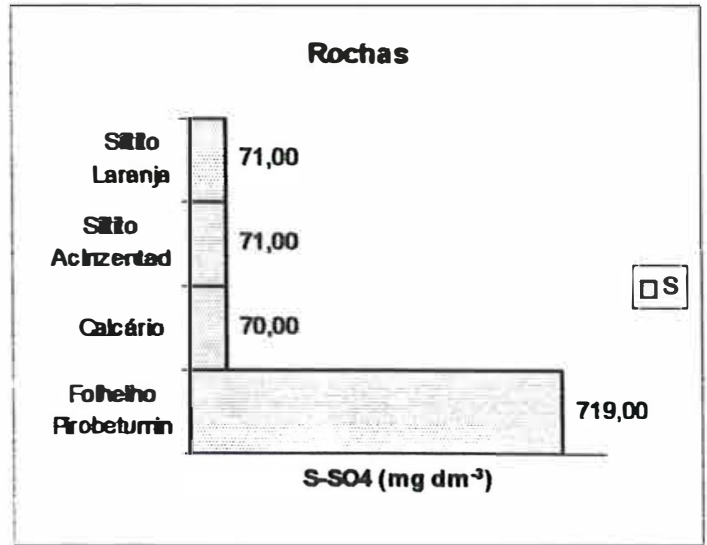

Figura 42 -Teores de enxofre nas rochas sãs coletadas na frente de lavra da mineração do calcário da formação Irati.

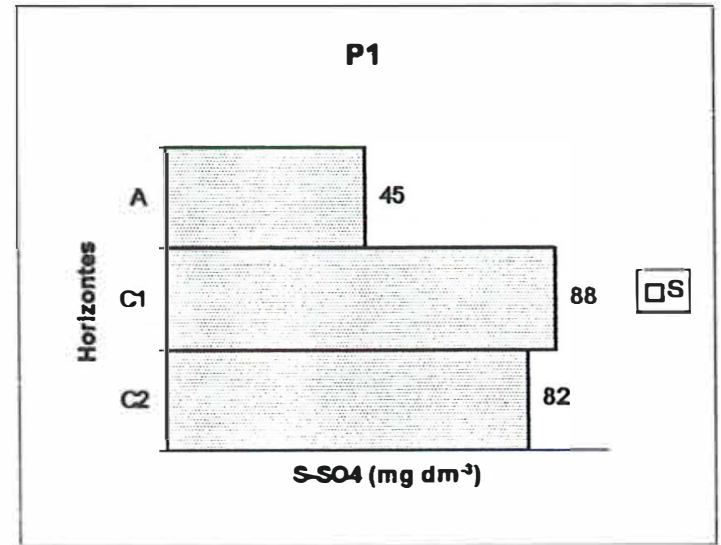

Figura 43 -Teores de enxofre no perfil P1 com 2 anos de deposição.

Observando-se as figuras 43 a 47 pode-se notar que ocorre uma tendência em diminuição dos teores de $\mathrm{S}^{-\mathrm{SO}_{4}}$ nas camadas mais superficiais e do seu conseqüente aumento com a profundidade nos perfis estudados, caracterizando a lixiviação deste ânion e essa tendência á incrementada o tempo de exposição do rejeito.

No presente estudo, observa-se que a tendência de lixiviação do $\mathrm{S}_{-} \mathrm{SO}_{4}$ é incrementada com a idade do banco de rejeito. Comparando-se os perfis P2, P3, P4 e P5, abertos em bancos que possuem o mesmo tipo de material de rejeito, mas com idades diferentes, nota-se que a área de 15 anos apresenta um grande aumento na concentração desse ânion (1256 mg dm $\left.\mathrm{m}^{-3}\right)$ já no horizonte subsuperficial $\mathrm{Cl}$, que se apresenta numa profundidade de 0 a $20 \mathrm{~cm}$. Em profundidades aproximadas a de $\mathrm{Cl}$ em P2, os perfis abertos nas áreas mais antigas (32 anos) exibem teores desse ânion expressivamente inferiores em comparação ao encontrado na subsuperficie de P2 (horizonte $\mathrm{C} 1$ ). $\mathrm{O}$ incremento abrupto dos valores da concentração de $\mathrm{S}_{-} \mathrm{SO}_{4}$, nos perfis das áreas mais antigas, acontece apenas nos horizontes mais profundos com valores acima de $1743 \mathrm{mg}$ $\mathrm{dm}^{-3}$. 
Ainda nesta área de 32 anos, a concentração de $\mathrm{S}_{-}-\mathrm{SO}_{4}$ apresenta um pequeno incremento nos horizontes superficiais $\mathrm{e}$ isso pode ser decorrente da intemperização de fragmentos rochosos em superficie, como também da ciclagem do enxofre pela vegetação (figuras 44 e 47).

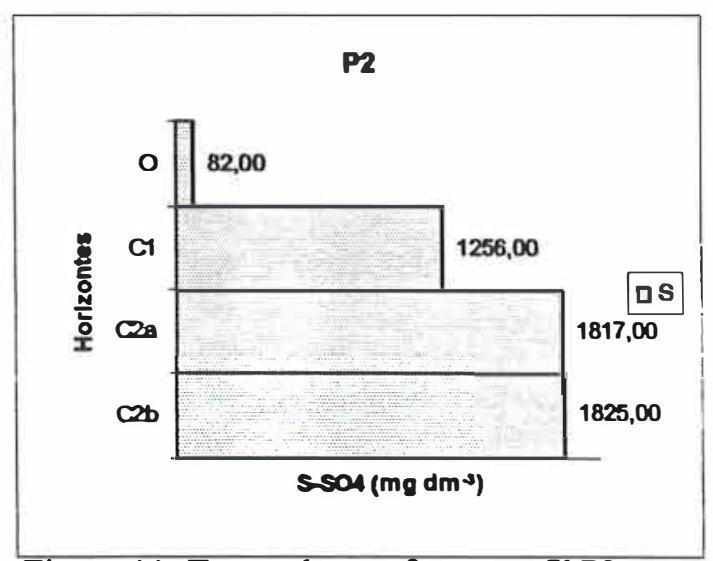

Figura 44 -Teores de enxofre no perfil P2 coml4 anos de deposição

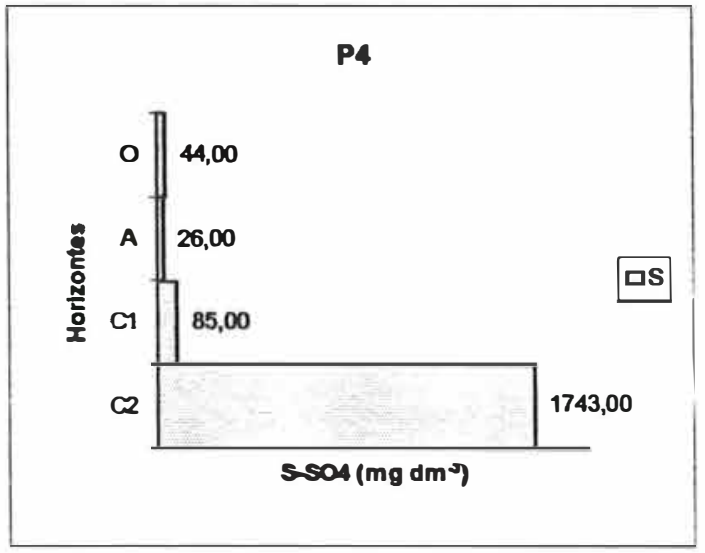

Figura 46 - Teores de enxofre enxofre no solo no perfil P4 com 32 anos de deposição

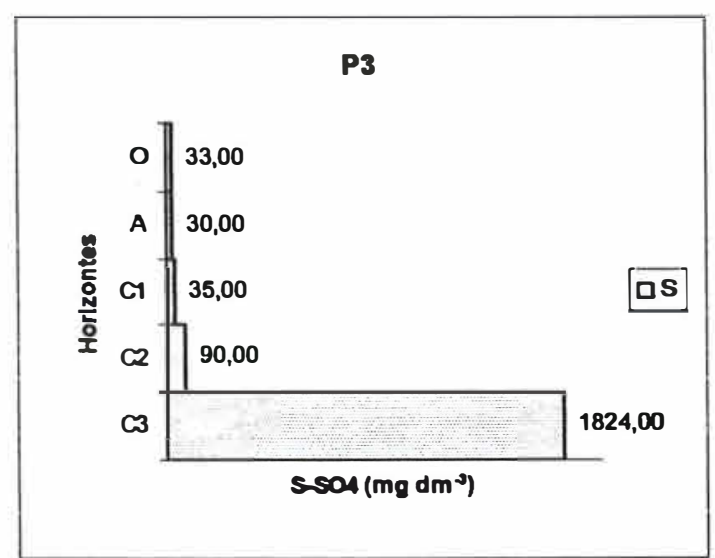

Figura 45 - Teores de enxofre no perfil P3 com 32 anos de deposição

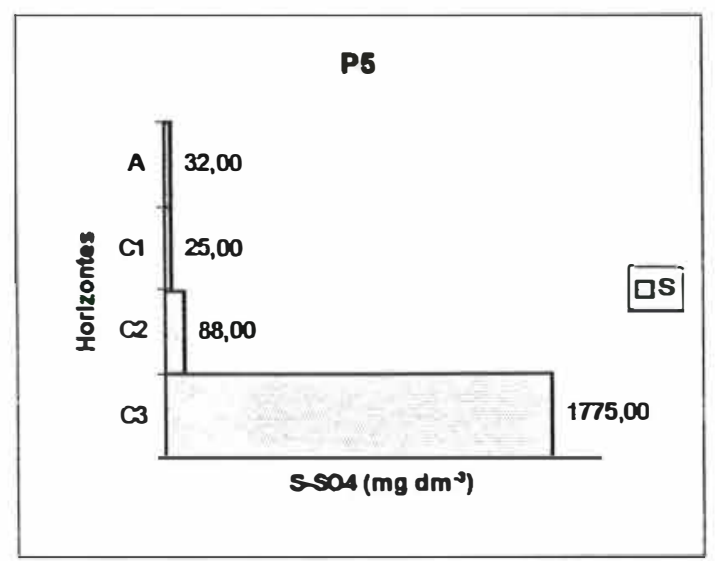

Figura 47 - Teores de enxofre do enxofre no solo no perfil P5 com 32 anos de dedosicão

Alguns teores de sulfato encontrados nestes solos de mina (P2, P3, P4 e P5), excedem os teores encontrados nas rochas sãs que constituem o rejeito (figura 42), principalmente nas camadas mais profundas, porém isso não implicou na redução dos valores de $\mathrm{pH}$ nestes perfis, pois, de acordo com vários autores, a acidez gerada pela oxidação da pirita promove a dissolução dos carbonatos, neutralizando a acidez e 
liberando $\mathrm{Ca}^{+2}$ e $\mathrm{Mg}^{+2}$ e formando sais solúveis com o $\mathrm{SO}_{4}^{-2}$ (Caruccio et al. 1988, Ritsema \& Groenenberg, 1993 e Doolittle et al., 1993). Devido a alta solubilidade destes sais (Ritsema \& Groenenberg, 1993), pode ocorrer subsequente lixiviação dos sais formados e, com o aumento da atividade iônica do $\mathrm{CaSO}_{4}$, o gipso em espaços vazios ou na superficie das rochas (Doolittle et al., 1993).

De fato, no presente estudo foi observado a presença de cristais de gipso nos perfis estudados, sendo que o conteúdo e o tamanho destes cristais aumentavam com a profundidade (anexo Al, página 150).

\section{f) Cátions trocáveis}

Assim como em Roberts et al. (1988 b) o se refere à este cátions como sendo "trocáveis" mas, em senso estrito estes cátions refletem os cátions extraíveis, os quais incluem àqueles retidos no complexo de troca como àqueles associados às superficies cortadas ou desgastadas do cimento de carbonático e dos grãos da matriz ou ainda aos sais solúveis (Doolittle et al., 1993 e Haering et al., 1993).

Apesar das oscilações nos valores de concentração devido a heterogeneidade dos constituintes do rejeito, pode-se observar algumas tendências de comportamento dos elementos nestes solos em formação.

As figuras 48 a 58 ilustram o comportamento dos cátions trocáveis presentes nos perfis abertos nos montes de rejeitos de diferentes idades e nas rochas sãs coletadas na frente de lavra da mineração do calcário Irati.

\section{f.1) Cálcio e Magnésio}

Pela analise feita do pó das rochas sãs retiradas diretamente da frente de lavra, pode-se verificar que a maior quantidade de cálcio e magnésio disponivel fica por conta do calcário, $260 \mathrm{mmol}_{\mathrm{c}} \mathrm{dm}^{-3}$ e $230 \mathrm{mmol}_{\mathrm{c}} \mathrm{dm}^{-3}$ respectivamente (figura 48). Os solos de mina neste estudo geralmente apresentaram maiores concentrações de $\mathrm{Ca}$ e $\mathrm{Mg}$ prontamente disponivel que a própria rocha o que pode indicar que a exposição destes 
materiais às novas condições de superficie está aumentando a disponibilidade destes elementos devido à oxidação de materiais reduzidos e intemperização dos carbonatos.

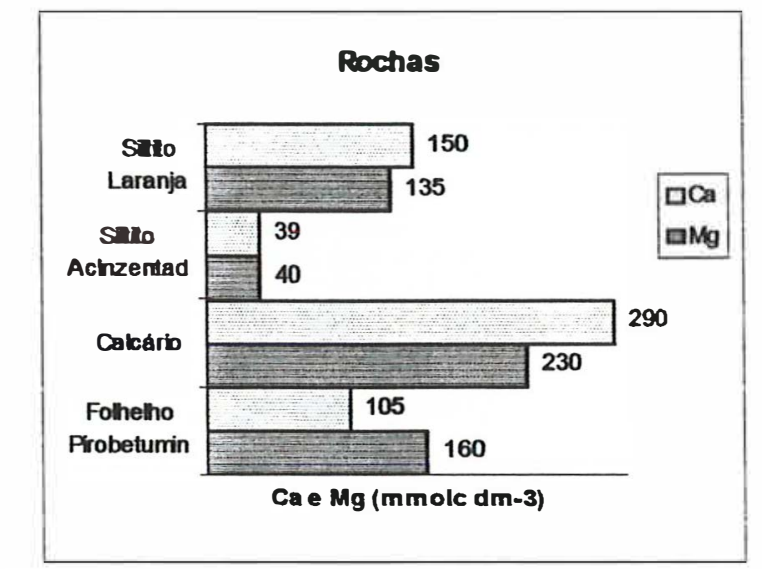

Figura 48 - Cálcio e magnésio trocáveis das rochas coletadas na frente de levra

O folhelho apresentou maiores quantidades de magnésio que de cálcio. Devemos recordar que se trata de uma rocha sedimentar de origem, formada deposição de restos orgânicos e minerais. Os restos orgânicos podem ter sido formados, dentre outros, por sedimentação de algas que clorofiladas que contem magnésio na estrutura da clorofila.

Levando-se em conta todos os perfis, os teores de Ca variam de 160 $\mathrm{mmol}_{\mathrm{c}} \mathrm{dm}^{-3}$ a $1140 \mathrm{mmol}_{\mathrm{c}} \mathrm{dm}^{-3}$ e os de $\mathrm{Mg}$ variam entre $125 \mathrm{mmol}_{\mathrm{c}} \mathrm{dm}^{-3}$ a $460 \mathrm{mmol}_{\mathrm{c}}$ $\mathrm{dm}^{-3}$ e, de acordo com Catani e Jacinto (1974), citados por Mello et al. (1989), estes teores estão acima dos níveis considerados altos para os solos do Estado de são Paulo. Os altos teores de $\mathrm{Ca}$ e $\mathrm{Mg}$ encontrados neste estudo se deve às altas concentrações destes elementos no cimento carbonático das rochas constituintes do rejeito, como também aos associados à carbonatos solúveis no extrator (Haering et al., 1993 e Roberts et al., 1988 (a e b) respectivamente).

No perfil P1 (2 anos), que possui rejeitos constituído de uma mescla de materiais rochosos e argilosos, os valores de concentração de cálcio varia entre 125 a 315 mmol $_{\mathrm{c}} \mathrm{dm}^{-3}$ e os de magnésio varia entre 125 a $180 \mathrm{mmol}_{\mathrm{c}} \mathrm{dm}^{-3}$, sendo que as maiores 
concentrações destes elementos são encontradas no horizonte A (figura 49). Isso pode estar relacionado ao maior intemperismo de fragmentos de carbonatos em seu horizonte superficial pois, fragmentos rochosos se alteram rapidamente próximos à superficie nos solos de mina (Schafer et al., 1980, Jonhson et al, 1982 e Ciolkosz et al., 1985) e, como constatou Roberts et al. (1988 b) no segundo ano de observação, a dissolução do cimento carbonático pode provocar altos níveis de $\mathrm{Ca}$ e $\mathrm{Mg}$ trocáveis em solos de mina muito jovens.
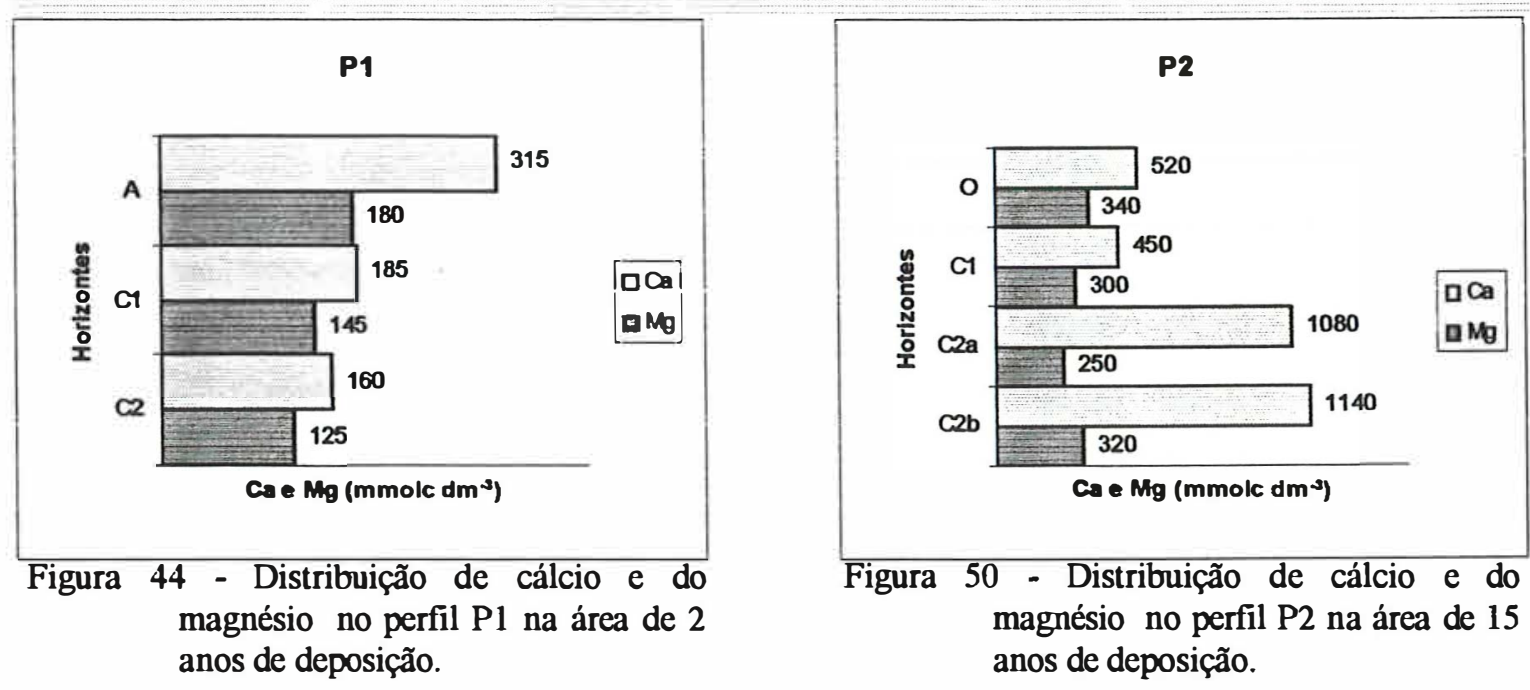

Nos perfis P2, P3, P4 e P5 (figuras 56 a 53), formados por uma mescla de material rochoso dominada por fragmentos de calcário+sílex e folhelhos pirobetuminosos em vários estágios de alteração, fica evidente a lixiviação do cálcio que apresenta uma tendência gradativa de incremento de seus teores a medida em que aumenta a profundidade. A lixiviação é um dos evidentes processos iniciais que ocorrem na de formação dos solos de mina (Anderson, 1977).

$\mathrm{O}$ cálcio lixivia com um par iônico, como o sulfato. Na dinâmica do intemperismo dos rejeito aqui estudados, a pirita se oxida, liberando íons $\mathrm{SO}_{4}{ }^{-2}$. A geração ácida promove intemperização dos carbonatos e a formação sais solúveis $\left(\mathrm{CaSO}_{4} \cdot 2 \mathrm{H}_{2} \mathrm{O}\right)$ que são lixiviados (Caruccio et al. 1988, Ritsema \& Groenenberg, 1993). 
Sais de sulfato de cálcio (como os retratados na foto $5 \mathrm{~B}$ da página $55 \mathrm{e}$ identificados na figura 64 na página 121) puderam ser observados na análise morfológica no presente estudo, onde se notou um incremento da quantidade e tamanho dos cristais de sulfato de cálcio com o aumento da profundidade dos perfis. Estes cristais de aciculares podem ser encontrados em meio ao espaço poral na matriz do solo, na superficie das rochas, e/ou envolvendo as raízes, como também evidenciaram Doolittle et al. (1993).

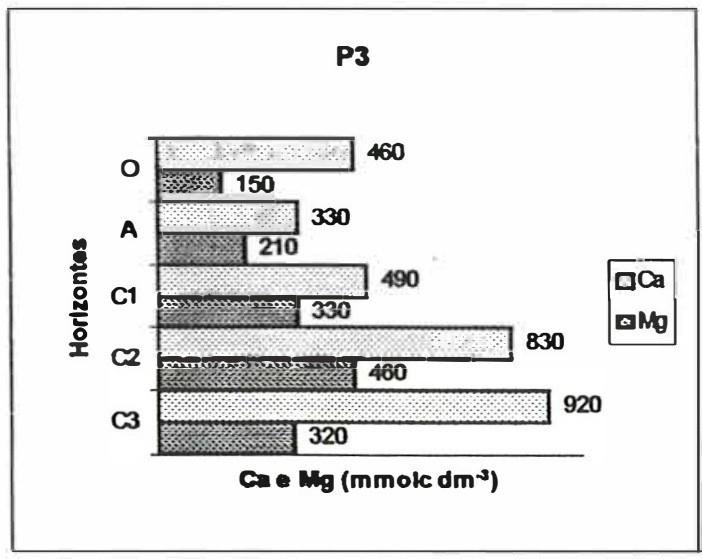

Figura 51- Distribuição de cálcio e do magnésio no perfil P3 na área de 32 anos de deposição.

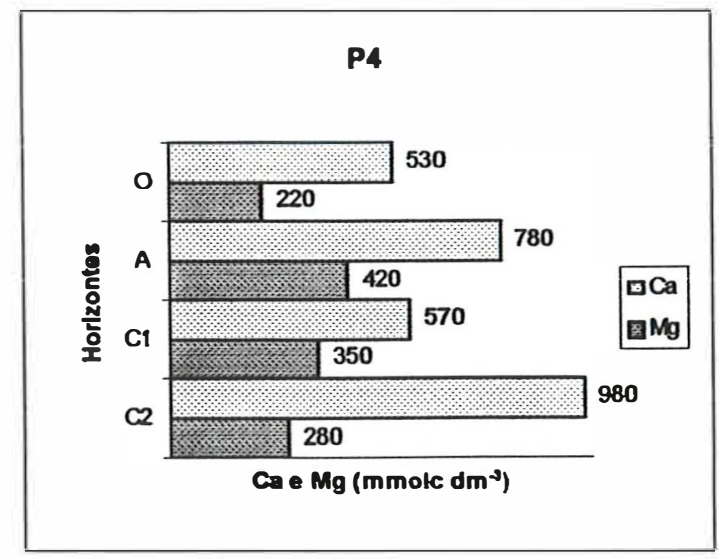

Figura 52 - Distribuição de cálcio e do magnésio no perfil P4 na área de 32 anos de deposição.

Com relação a idade do banco de deposição, pode-se notar a ocorrência de lixiviação do Ca a partir do perfil P2 (15 anos, figura 50), porém o teor deste elemento apresentou um abrupto incremento de sua concentração já a partir de $20 \mathrm{~cm}$ de profundidade, atingindo $1080 \mathrm{mmol}_{\mathrm{c}} \mathrm{dm}^{-3}$ já no horizonte $\mathrm{C} 2{ }_{1}$ e chegando a $1140 \mathrm{mmol}_{\mathrm{c}}$ $\mathrm{dm}^{-3}$ no horizonte $\mathrm{C} 2_{2}(40-80 \mathrm{~cm})$.

A lixiviação, no entanto, é mais evidente nos perfis P3 e P4, abertos nos bancos mais antigos, de 32 anos, e fica mais clara para o cálcio (figuras 51 e 52, respectivamente). Embora estes perfis apresentam maiores quantidades de cálcio nas camadas mais profundas, chegando a $920 \mathrm{mmol}_{\mathrm{c}} \mathrm{dm}^{-3}$ e $980 \mathrm{mmol}_{\mathrm{c}} \mathrm{dm}^{-3}$ em P3 e P4, respectivamente, estes valores são relativamente menores do que os encontrados a partir 
de $20 \mathrm{~cm}$ de profundidade no perfil mais recente P2 (15 anos). Isso pode ser uma evidência de que os teores de cálcio sofrem um decréscimo com o tempo de exposição do rejeito, conforme sugerem Roberts et al. (1988 a e b), Haering et al. (1993) e Soave (1996).

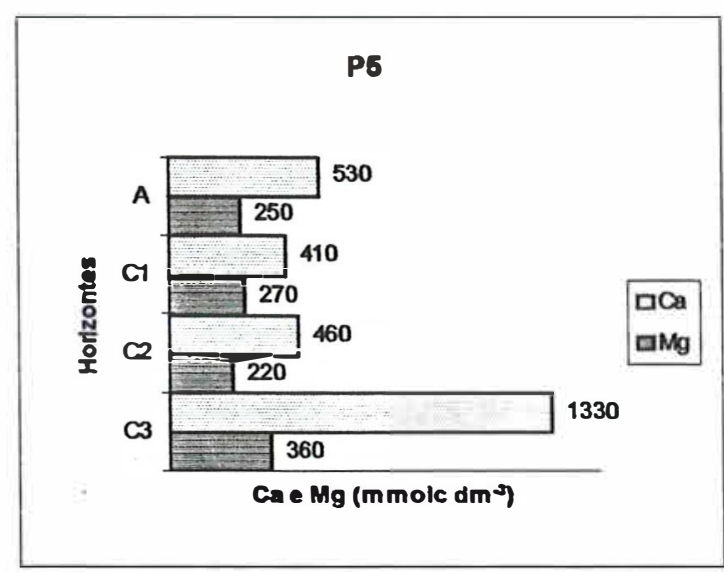

Figura 53- Distribuição de cálcio e do magnésio no perfil P5 na área de 32 anos de deposição.

O pequeno aporte das concentrações de cálcio observado nos horizontes superficiais de P2, P3 e P5, em relação a seus respectivos horizontes subsuperficiais, pode ser devido a intemperização dos carbonatos e ciclagem do elemento pela cobertura vegetal (Roberts et al., 1988 (a e b) e Haering et al., 1993).

O perfil P5 (32 anos) apresenta um teor de $460 \mathrm{mmol}_{\mathrm{c}} \mathrm{dm}^{-3}$ no horizonte C2. Posteriormente ocorre um brusco aumento na concentração de cálcio (1330 mmol $\mathrm{dm}^{-3}$ ) no horizonte $\mathrm{C} 3$. Esse aumento acentuado provavelmente está relacionado ao maior adensamento da camada $\mathrm{C} 2$, já que se trata de um horizonte adensado (ver anexo A1.5, página 158) que pode vir a dificultar a livre percolação de água no perfil e diminuir sua velocidade de infiltração.

A água que atravessa $\mathrm{C} 2$, em menor quantidade promove alterações nas rochas no horizonte $\mathrm{C} 3$ mas não é suficiente para que ocorra a lixiviação dos sais solúveis que se formam, implicando na acumulação dos mesmos. 
Embora fique claro a ocorrência de lixiviação de Ca na maioria dos perfis e que esse elemento aparentemente possui uma tendência em diminuir seus teores com o passar do tempo, o magnésio não apresenta uma tendência clara de lixiviação. Mas esse elemento pode estar sendo lixiviado mais rapidamente que o $\mathrm{Ca}$ (Haering et al., 1993) e, devido a sua maior solubilidade, não se acumula até as profundidades analisadas como efetivamente acontece com o $\mathrm{Ca}$ na forma de gipso.

Os menores valores de concentração de $\mathrm{Mg}$ coincidirem com o perfil mais recente $\mathrm{P} 1$ ( 2 anos), mas não se pode fazer nenhuma relação com a idade do solo devido sua alta variabilidade dentro e entre os perfis.

\section{f.2) Potássio e sódio}

Nos perfis dos solos de mina aqui estudados, os teores variaram de 0,8 mmol $_{c} \mathrm{dm}^{-3}$ a $7,4 \mathrm{mmol}_{\mathrm{c}} \mathrm{dm}^{-3}$ para o potássio e $0,12 \mathrm{mmol}_{\mathrm{c}} \mathrm{dm}^{-3}$ a $7,5 \mathrm{mmol}_{\mathrm{c}} \mathrm{dm}^{-3}$ para o sódio.

O potássio e o sódio apresentam comportamentos opostos em todos os perfis estudados, ou seja, enquanto o potássio apresenta maiores teores próximo à superficie, o sódio se concentrou nos horizontes mais profundos, onde exibe maiores teores em relação aos encontrados em superficie e assim segue para os demais perfis.

O perfil P1 ( 2 anos), aberto em uma área que recebeu uma mescla de materiais rochosos e argilosos, apresentou teores de $\mathrm{K} \mathrm{e} \mathrm{Na}$ variando de $2,5 \mathrm{mmol}_{\mathrm{c}} \mathrm{dm}^{-3} \mathrm{a}$ $10,20 \mathrm{mmol}_{\mathrm{c}} \mathrm{dm}^{-3}$ e $2,6 \mathrm{mmol}_{\mathrm{c}} \mathrm{dm}^{-3}$ a $6,9 \mathrm{mmol}_{\mathrm{c}} \mathrm{dm}^{-3}$, respectivamente, onde já se nota a lixiviação do $\mathrm{Na}$ juntamente à grande disponibilidade de $\mathrm{K}$ no horizonte superficial deste perfil (figura 54). Fica caracterizada então a lixiviação do sódio desde P1 (2 anos), dentre os cátions básicos o sódio principalmente apresenta rápida lixiviação nos solos de mina (Wood \& Pattry, 1989). 


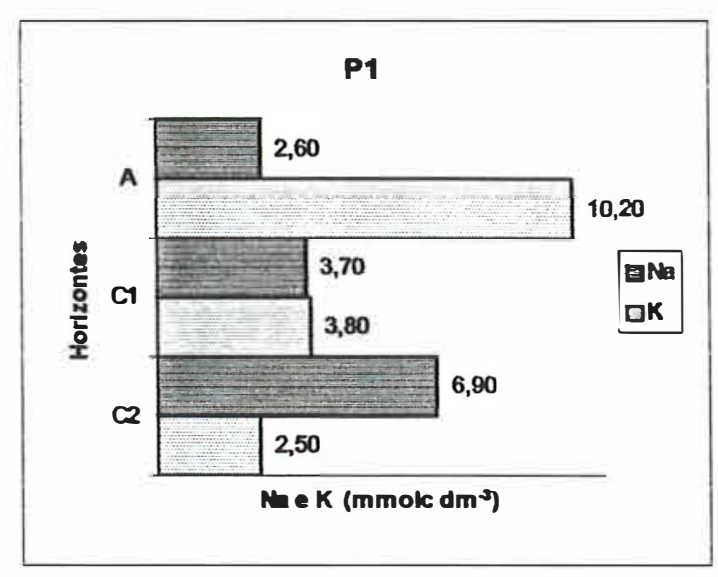

Figura 55 Teores de Na e K no perfil Pl na área de 2 anos de deposição.

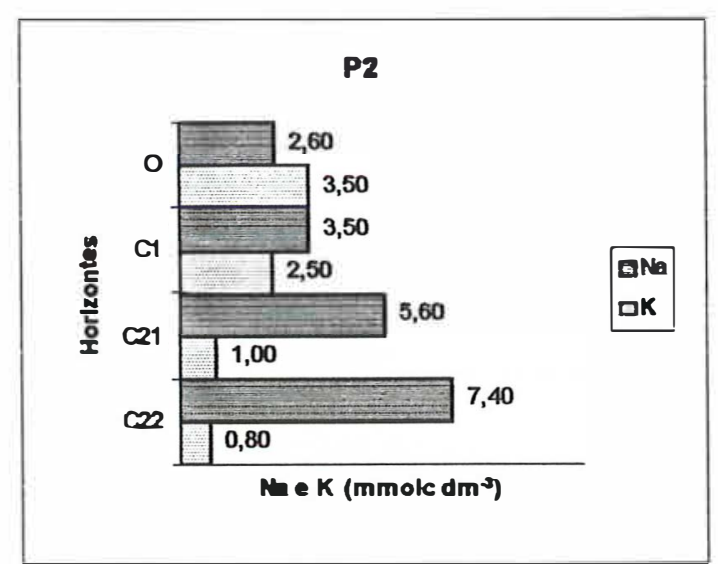

Figura 56 - Teores de Na e K no perfil P2 na área de 15 anos de deposição.

Embora ocorra a lixiviação do sódio nestes solos de mina, no presente estudo não se pode relacionar os teores desse elemento a idade dos rejeitos. Soave (1996) também não encontrou relação do sódio com a idade dos solos de mina desenvolvidos sobre rejeitos da mineração de calcário na região de Rio Claro.

Os maiores teores de potássio se encontram próximos a superficie em todos os perfis, reduzindo gradativamente suas concentrações à medida que se avança a profundidade.

Comparando-se os perfis situados em bancos de rejeitos constituídos de mesmo material rochoso (mescla de calcário + silex e folhelhos pirobetuminosos), podese observar uma tendência de aumento dos teores de K nos perfis P3, P4 e P5 situados na área mais antiga ( 32 anos, figuras 56,57 e 58 respectivamenmte) em comparação ao perfil P2 (15 anos). Essa tendência fica mais clara próximo a superficie. 


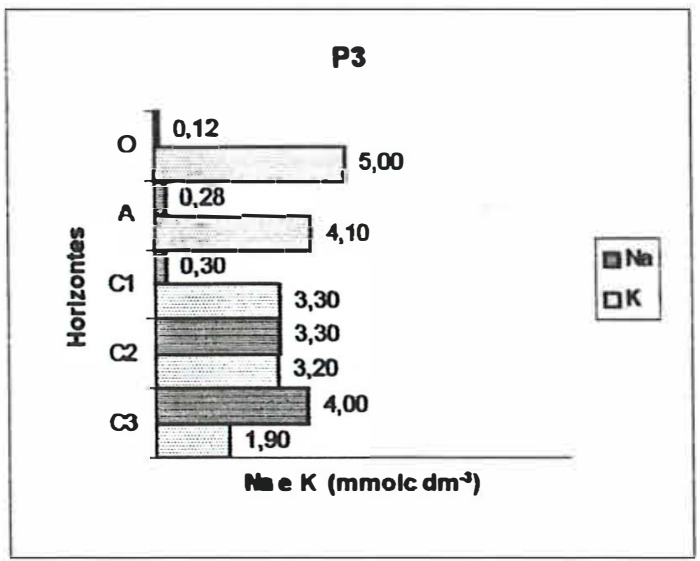

Figura 56 - Teores de Na e K no perfil P3 na área de 32 anos de deposição.

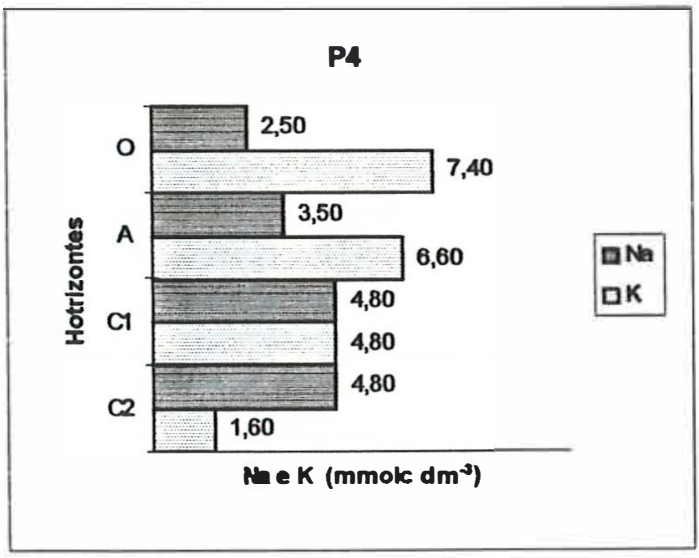

Figura 57 - Teores de Na e K no perfil P4 na área de 32 anos de deposição.

$\mathrm{O}$ perfil $\mathrm{P} 2$, na área de 15 anos, apresentou um conteúdo superficial de potássio de $3,5 \mathrm{mmol}_{\mathrm{c}} \mathrm{dm}^{-3}$ (figura 61), enquanto que os teores superficiais deste elemento nos perfis abertos na área mais antiga variaram de 5 mmol $_{c} \mathrm{dm}^{-3}$ a $7,4 \mathrm{mmol}_{c}$ $\mathrm{dm}^{-3}$.

A maior disponibilidade conteúdos desse elemento encontrados nas áreas mais velhas possivelmente se justifica devido ao intemperismo dos folhelhos com da mica (Hower et al. 1992) que libera $\mathrm{K} \mathrm{e}$, além disso à subsequente ciclagem do nutriente pelas plantas (Shafer et al. 1980, Roberts et al., 1988 (a e b), Haering et al., 1993 e Soave, 1996).

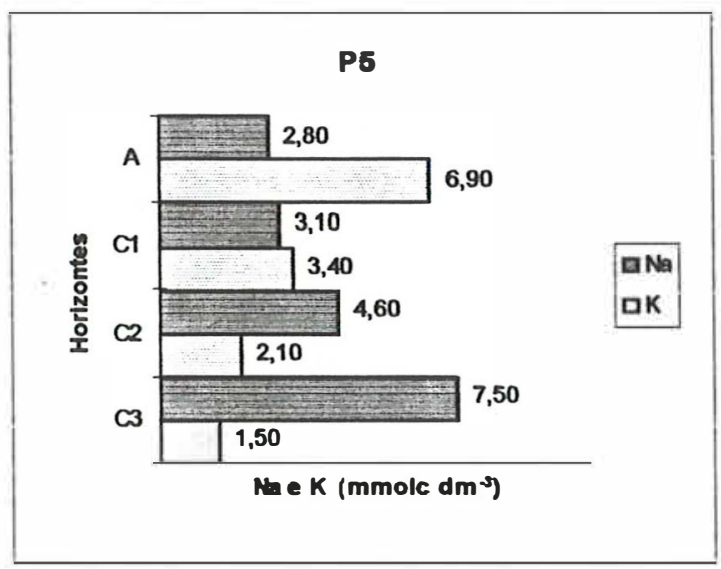

Figura 58 - Teores de Na e K no perfil P5 na área de 32 anos de deposição. 
g) Soma de bases (S), capacidade de troca catiônica (CTC) e porcentagem de saturação de bases $(\mathrm{V} \%)$.

Conforme os niveis encontrados em Mello et al. (1989), os solos recentes da mineração de calcário apresentaram-se com altos valores de soma de bases, alta a muito alta CTC e alta porcentagem de saturação de bases, o que confere um caracter eutrófico a estes solos. A tabela 3 traz os valores de S, CTC e V\% destes solos de mina.

De maneira geral, os valores de CTC foram mais elevados nos horizontes superficiais e nos horizontes mais profundos. $\mathrm{O}$ aumento nos valores de CTC pode estar sendo conferido pelo acúmulo de mateira orgânica e intemperização de minerais na superficie destes solos.

Em muitos casos o valor de S ou da CTC (obtidos pelo método direto, por saturação com $\mathrm{Ca}$ ) é inferior à soma das bases encontradas na análise química para fins de fertilidade para um definido horizonte. Por exemplo, se somarmos todas as bases quantificadas na análise para fins de fertilidade, o maior valor se soma de bases alcançado é de 1468,20 $\mathrm{mmol}_{\mathrm{c}} \mathrm{dm}^{-3}$ (horizonte C2.2 de P2). Esse valor é bem superior que o maior valor de soma de bases calculada com a CTC obtida pelo método direto de saturação com cálcio $\left(906 \mathrm{mmol}_{\mathrm{c}} \mathrm{dm}^{-3}\right)$. Portanto, é possível que as análises químicas para fins de fertilidade realizadas neste estudo, quantifica não só os cátions trocáveis, mas também aqueles solúveis, que podem estar presentes na forma de sais e carbonatos como sugerem Roberts et al. (1988 a e b), Haering et al. (1993) e Doolittle et al. (1993).

Tomando-se os perfis abertos em bancos de rejeitos constituídos do mesmo material rochoso e com idades diferentes, observa-se uma tendência de aporte da soma de bases nos horizontes mais profundos, mas não é clara a influência do tempo de exposição do rejeito sobre a soma de bases.

O incremento da CTC na superficie de todos os perfis estudados pode estar relacionado à acumulação de matéria orgânica superficial (Anderson, 1977, Varela et al., 1993). 
Tabela 3 - Valores de soma de bases (S), capacidade de troca catiônica (CTC) e saturação de bases (V\%) nos solos em formação sobre rejeitos da mineração de calcário da Formação Irati.

\begin{tabular}{|c|c|c|c|c|c|}
\hline Perfil & Horizonte & $\begin{array}{c}\text { Profundidade } \\
\mathrm{cm}\end{array}$ & $\mathbf{S}$ & $\begin{array}{c}\text { CTC } \\
\text { mmol }_{\mathrm{c}} \mathrm{dm}^{-3}\end{array}$ & $\begin{array}{l}\mathrm{V} \\
\%\end{array}$ \\
\hline P1 & $\mathbf{A}$ & $0-3$ & 381 & 396 & 96 \\
\hline \multirow{2}{*}{ (2 anos) } & C1 & $3-30$ & 312 & 334 & 93 \\
\hline & $\mathrm{C2}$ & $30-70$ & 266 & 288 & 92 \\
\hline P2 & $\mathbf{0}$ & $3-0$ & 605 & 618 & 98 \\
\hline \multirow[t]{3}{*}{ (14 anos) } & C1 & $0-20$ & 493 & 508 & 97 \\
\hline & C2a & $20-40$ & 851 & 873 & 99 \\
\hline & $\mathbf{C 2 b}$ & $40-100$ & 783 & 799 & 98 \\
\hline P3 & $\mathbf{0}$ & $3-0$ & 621 & 649 & 96 \\
\hline \multirow[t]{4}{*}{ (32 anos) } & $\mathbf{A}$ & $0-3$ & 494 & 506 & 98 \\
\hline & $\mathrm{C1}$ & $3-20$ & 428 & 440 & 97 \\
\hline & $\mathrm{C} 2$ & $20-80$ & 455 & 458 & 97 \\
\hline & $\mathrm{C3}$ & $80-120$ & 906 & 922 & 98 \\
\hline P4 & $\mathbf{0}$ & $3-0$ & 710 & 728 & 98 \\
\hline \multirow[t]{3}{*}{ (32 anos) } & $\mathbf{A}$ & $0-3$ & 559 & 570 & 98 \\
\hline & C1 & $3-30$ & 487 & 502 & 97 \\
\hline & $\mathrm{C2}$ & $30-70$ & 836 & 851 & 98 \\
\hline P5 & $\mathbf{A}$ & $0-4$ & 614 & 627 & 98 \\
\hline \multirow{3}{*}{ (32 anos) } & C1 & $4-50$ & 558 & 574 & 97 \\
\hline & $\mathrm{C2}$ & $50-70$ & 580 & 592 & 98 \\
\hline & C3 & $70-100$ & 686 & 702 & 98 \\
\hline
\end{tabular}

h) Micronutrientes

A tabela 4 traz os teores de $\mathrm{B}, \mathrm{Cu}, \mathrm{Fe}, \mathrm{Mn}$ e $\mathrm{Zn}$ encontrados nos perfis abertos nos bancos de rejeitos da mineração de calcário da Formação Iratí.

Considerando-se todos os perfis os teores de boro variam de $0,15 \mathrm{mg} \mathrm{dm}^{-3}$ a $1,10 \mathrm{mg} \mathrm{dm}^{-3}$. O cobre varia de $1,5 \mathrm{mg} \mathrm{dm}^{-3}$ a $5,2 \mathrm{mg} \mathrm{dm}^{-3}$, tendo uma tendência de exibir os menores teores nos horizontes superficiais dentro de cada perfil. Isso pode ser devido à complexação desse íon à matéria orgânica na superficie destes solos de mina.

O ferro extraível varia de $17 \mathrm{mg} \mathrm{dm}^{-3}$ a $93,4 \mathrm{mg} \mathrm{dm}^{-3}$, sendo que seu maior teor é encontrado no horizonte $\mathrm{C} 1$ do perfil P1 (2 anos) provavelmente se deve à possível condição de redução evidenciada pela presença de mosqueados em alguns pontos desse perfil (ver anexo Al.1, página 151).

Nos perfis mais recentes $\mathrm{P} 1$ e P2, de 2 e 15 anos respectivamente, o ferro apresenta seus menores valores nos horizontes superficiais, enquanto que, nas áreas mais 
antigas, de 32 anos, ocorreu um maior teor de $\mathrm{Fe}$ nos horizontes superficiais em relação aos subsuperficiais.

Mesmo no perfil P5 que, embora apresente o maior teor de Fe no horizonte $\mathrm{C} 3$, observa-se que em sua superficie o teor deste elemento foi mais elevado que na subsuperficie, sendo que o teor de Fe na superficie de P5 é quase o dobro do horizonte subjacente $\mathrm{Cl}$.

Comparando-se os teores de $\mathrm{Fe}$ dos perfis $\mathrm{P} 3, \mathrm{P} 4$ e os horizontes $\mathrm{A}, \mathrm{Cl}$ e C2 do perfil, nota-se que o ferro apresenta-se menos disponível no perfil P5. As razões que levam a estes menores teores em relação aos demais perfis P3 e P4 (todos com 32 anos de exposição) não são muito claras, mas podem ter relação ao manejo da área de P5 e à inexistência de um horizonte $\mathrm{O}$ distinto neste perfil. Nos perfis P3 e P4 os maiores teores de ferro estão coincidindo com os horizontes $\mathrm{O}$, podendo ser uma indicação de que esse elemento está sofrendo ciclagem pela vegetação de P3 e P4.

O Mn e o $\mathrm{Zn}$ variam de $2,8 \mathrm{mg} \mathrm{dm}^{-3}$ a $61,4 \mathrm{mg} \mathrm{dm}^{-3}$ e $0,6 \mathrm{mg} \mathrm{dm}^{-3}$ a 10 $\mathrm{mg} \mathrm{dm}{ }^{-3}$, respectivamente e, dentro de cada perfil, apresentam maiores concentrações nos horizontes superficiais.

Embora é possivel perceber algumas tendências de comportamento destes cátions, não se pode fazer nenhuma conclusão efetiva a partir destes dados. Porém, algumas diretrizes de estudos podem ser tomadas a partir da caracterização inicial aqui efetivada. 
Tabela 4 - Micronutrientes presentes nos solos em formação sobre rejeitos da mineração de calcário da Formação Irati.

\begin{tabular}{|c|c|c|c|c|c|c|c|}
\hline Perfil & Horizonte & $\begin{array}{c}\text { Profundidade } \\
\text { cm }\end{array}$ & B & $\mathrm{Cu}$ & $\begin{array}{c}F e \\
\mathrm{mgdm}^{-3}\end{array}$ & Mn & $\mathbf{Z n}$ \\
\hline $\mathbf{P 1}$ & $\mathbf{A}$ & $0-3$ & 1,10 & 1,9 & 18,2 & 61,4 & 2,7 \\
\hline \multirow[t]{2}{*}{ (2 anos) } & C1 & $3-30$ & 1,01 & 3,7 & 93,4 & 17,8 & 1,5 \\
\hline & $\mathrm{C2}$ & $30-70$ & 0,53 & 2,4 & 67,6 & 14,2 & 0,9 \\
\hline $\mathbf{P 2}$ & $\mathbf{0}$ & $3-0$ & 0,63 & 1,6 & 21,6 & 15,4 & 2,2 \\
\hline \multirow[t]{3}{*}{ (15 anos) } & C1 & $0-20$ & 0,55 & 2,3 & 26,6 & 13 & 1,5 \\
\hline & $\mathrm{C2}_{1}$ & $20-40$ & 0,51 & 4 & 55,6 & 14,2 & 1,6 \\
\hline & $\mathrm{C2}_{2}$ & $40-100$ & 0,40 & 3,6 & 36,8 & 14,4 & 1,6 \\
\hline P3 & $\mathbf{0}$ & $3-0$ & $* * *$ & 1,4 & 65,6 & 38,6 & 10,3 \\
\hline \multirow[t]{4}{*}{ (32 anos) } & $\mathbf{A}$ & $0-3$ & 0,66 & 1,7 & 23,8 & 37,6 & 5,0 \\
\hline & C1 & $3-20$ & 0,36 & 3,2 & 34,4 & 12,2 & 1,3 \\
\hline & $\mathrm{C2}$ & $20-80$ & 0,26 & 5,0 & 36,0 & 15,6 & 2,0 \\
\hline & C3 & $80-120$ & 0,33 & 4,0 & 37,6 & 13,2 & 1,7 \\
\hline P4 & $\mathbf{0}$ & $3-0$ & $* * *$ & 1,5 & 61,4 & 39,6 & 8,8 \\
\hline \multirow[t]{3}{*}{ (32 anos) } & $\mathbf{A}$ & $0-3$ & 0,79 & 1,9 & 28,6 & 25,0 & 1,9 \\
\hline & C1 & $3-30$ & 0,49 & 4,0 & 29,6 & 19,6 & 1,9 \\
\hline & $\mathrm{C} 2$ & $30-70$ & 1,10 & 3,5 & 36,2 & 9,4 & 1,4 \\
\hline P5 & $\mathbf{A}$ & $0-4$ & 0,20 & 2,2 & 32,2 & 39,0 & 3,2 \\
\hline \multirow[t]{3}{*}{ (32 anos) } & C1 & $4-50$ & 0,15 & 5,2 & 17,0 & 2,8 & 0,6 \\
\hline & C2 & $50-70$ & 0,56 & 3,1 & 18,0 & 15,2 & 0,8 \\
\hline & $\mathrm{C} 3$ & $70-100$ & 0,32 & 3,8 & 66,2 & 13,6 & 2,4 \\
\hline \multirow[t]{4}{*}{ Rochas } & Siltito laranja & - & 0,17 & 0,7 & 31,4 & 15,1 & 0,6 \\
\hline & Siltito acinzentado & - & 0,15 & 0,1 & 23,8 & 1,7 & 0,6 \\
\hline & Calcário & - & 0,13 & 0,2 & 500,0 & 21,8 & 0,2 \\
\hline & Folhelho pirobetum. & - & $* * *$ & 0,9 & 138,0 & 11,4 & 1,6 \\
\hline
\end{tabular}

** Boro não detertado pelo método de Abreu \& Abreu (1996) devido a amostra não permitir filtragem.

\subsubsection{Ferro livre}

Os teores de óxidos de ferro amorfo variaram entre $0,12 \%$ a $0,89 \%$ e os teores de óxidos de Fe cristalinos variaram entre $0,46 \%$ a 2,80 \% e ambos apresentaram uma tendência de elevação de seus teores com o aumento da profundidade.

Observando-se os perfis abertos em montes formados maioritariamente por fragmentos rochosos de calcário+silex e folhelhos pirobetuminosos, é possível notar que os valores mais altos de óxidos de ferro livre cristalinos se apresentam nos perfis mais antigos e, geralmente, nos horizontes mais profundos.

Nota-se também a influência do tempo de exposição do rejeito sobre os conteúdos de ferro livre comparando-se o maior teor de Fe cristalino nos perfiis P1 e P2 ( 2 e 15 anos, figuras 59 e 60) com os perfis abertos na área de 32 anos, onde conteúdos 
superiores a 1,24 \% (o maior conteúdo de Fe livre de P2) são freqüentes, principalmente nas camadas mais profundas (figuras 61, 62 e 63, respectivamente), o que pode ser um indício de que a dissolução do cimento férrico das rochas e a oxidação do ferro se dá de maneira rápida, aumentando seus teores com o tempo (Roberts et al., 1988 a e b, Haering et al., 1993, Varela et al. 1993).

Roberts et al. (1988 a e b) e Haering et al. (1993) notaram que logo após o incremento de Fe livre ocorreu um abaixamento de seus teores que presumidamente é devido à complexação do Fe com a matéria orgânica. Baseando-se neste autores, pode-se sugerir que os baixos conteúdos de Fe livre encontrados próximo à superficie de alguns perfis (P2 e P4, principalmente) pode ser devido à complexação do cátion com a matéria orgânica.

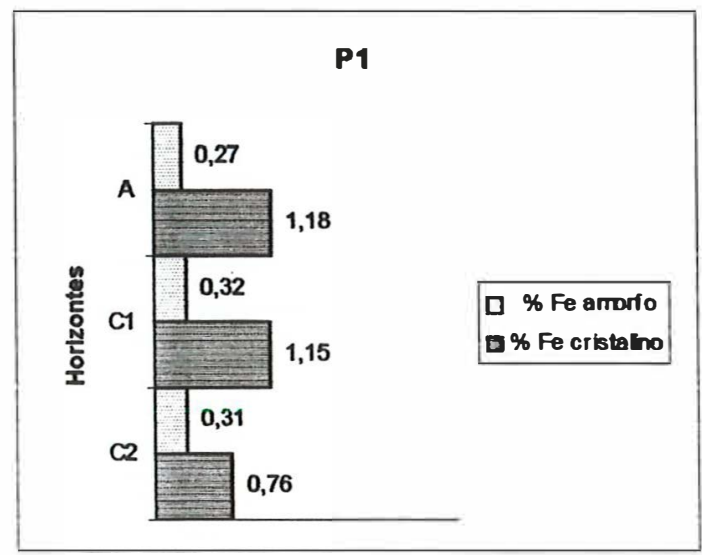

Figura 59 - Teores de $\mathrm{Fe}$ amorfo e Fe cristalinos no perfil $\mathrm{Pl}$, na área com 2 anos de exposição

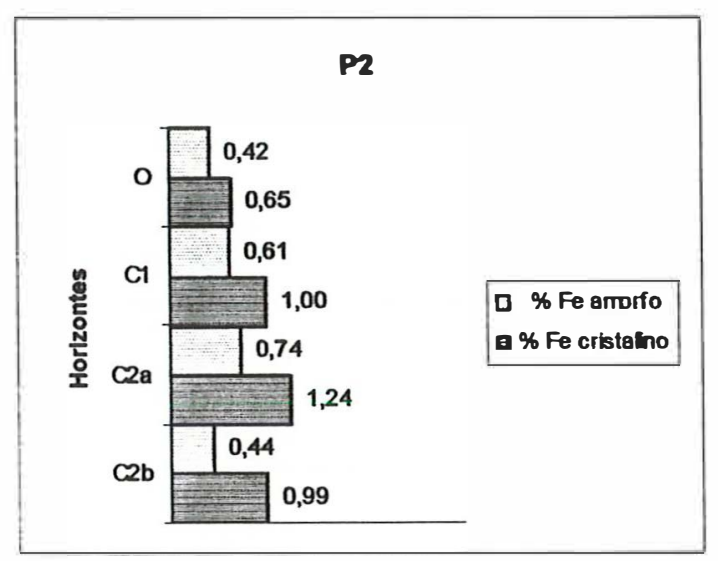

Figura 60 - Teores de Fe amorfo e Fe cristalinos no perfil P15, na área com 15 anos de exposição 


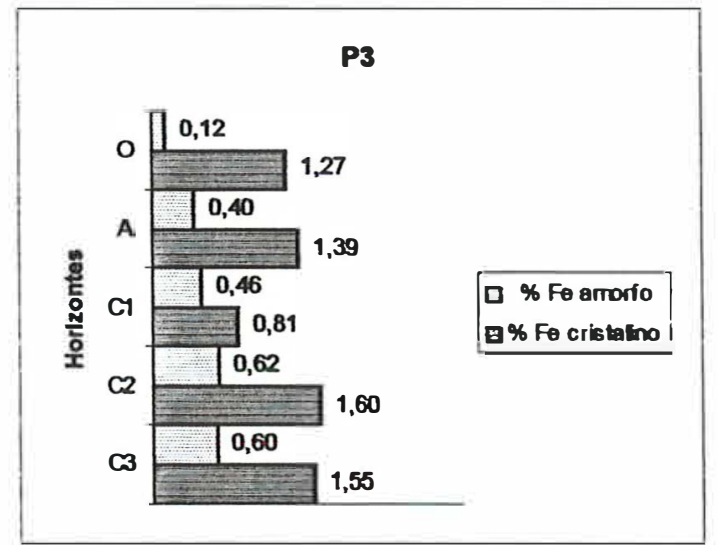

Figura 61 - Teores de Fe amorfo e Fe cristalinos no perfil $\mathrm{P} 3$, na área com 32 anos de exposição

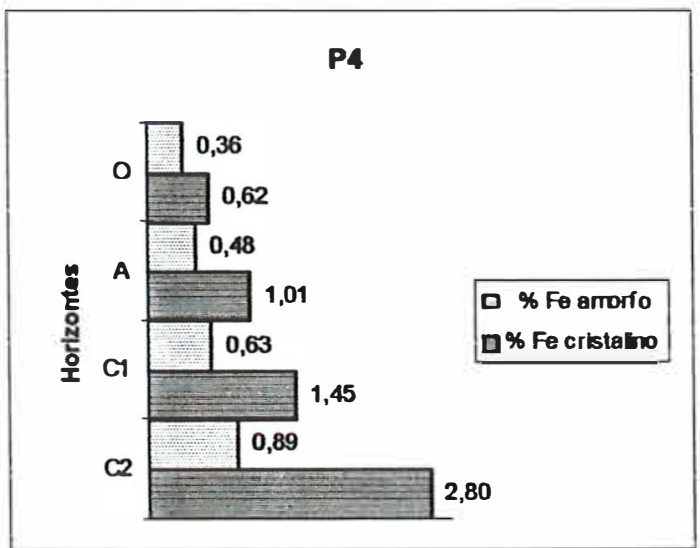

Figura 62 - Teores de $\mathrm{Fe}$ amorfo e Fe cristalinos no perfil $\mathrm{P} 4$, na área com 32 anos de exposição

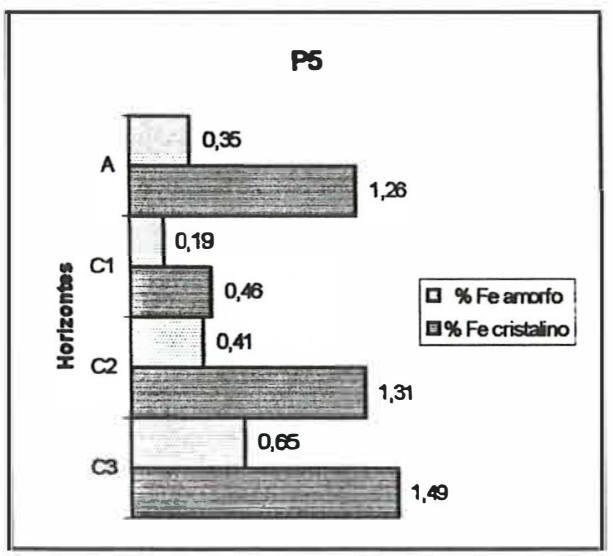

Figura 63 - Teores de Fe amorfo e Fe cristalinos no perfil P5, na área com 32 anos de exposição

\subsubsection{Ataque sulfúrico e alcalino e índices de intemperismo (Ki e Kr)}

Os teores de $\mathrm{SiO}_{2}, \mathrm{Al}_{2} \mathrm{O}_{3} \mathrm{Fe}_{2} \mathrm{O}_{3}$ e $\mathrm{TiO}_{2}$ geralmente se apresentaram maiores na fração argila $(<0,002 \mathrm{~mm})$ do que na fração TFSA $(<2 \mathrm{~mm})$ e divido a grande variabilidade destes teores, não se pode notar qualquer evidencia de migração destes elementos. 
Tabela 5 - Ataque sulfúrico e índices de intemperismo de rochas sãs constituintes dos rejeitos da mineração de calcário da Formação Irati

\begin{tabular}{|c|c|c|c|c|c|c|c|}
\hline \multirow[t]{2}{*}{ Rocha } & $\mathrm{SiO}_{2}$ & $\mathrm{AlO}_{3}$ & $\mathrm{Fe}_{2} \mathrm{O}_{3}$ & $\mathrm{TiO}_{2}$ & MnO & \multirow[t]{2}{*}{$\mathbf{K i}$} & \multirow[t]{2}{*}{$\mathbf{K r}$} \\
\hline & \multicolumn{5}{|c|}{$\%$} & & \\
\hline Siltito acinzentado & 18,20 & 6,93 & 4,02 & 0,42 & 0,10 & 4,46 & 2,36 \\
\hline Siltito laranja & 42,50 & 16,42 & 7,35 & 0,43 & 0,05 & 4,40 & 3,42 \\
\hline Calcário & 0,04 & 0,31 & 2,23 & 0,15 & 0,44 & 2,19 & 0,39 \\
\hline Folhelho Pirobetum. & 26,00 & 0,51 & 1,04 & 0,27 & 0,01 & 89,67 & 37,6 \\
\hline
\end{tabular}

Os índices de intemperismo Ki obtidos neste estudo, se apresentam muito variáveis e elevados tanto na fração TFSA como na fração argila. Os valores mínimos observados nas frações TFSA e argila são 4,17 e 3,46, respectivamente e os valores máximos observados são 147,33 e 102,34 para as frações TFSA e argila, respectivamente (tabela 6). Estes valores são mais elevados que os encontrados por Calero-Marino (1999) e Telles (1997) que encontraram valores de 2,02 a 4,10 e 2,01 a 3,77, respectivamente, em solos desenvolvidos sobre a Formação Irati.

Os altos valores de Ki se deve principalmente aos baixos conteúdos de $\mathrm{Al}_{2} \mathrm{O}_{3}$ aliados aos altos valores de $\mathrm{SiO}_{2}$ nestes materiais. Através da tabela 5 , pode-se evidenciar que, dentre as rochas sãs analisadas, o maior Ki pertence ao folhelho $(89,67)$ (tabela 5). Essa rocha apresenta uma elevada porcentagem de $\mathrm{SiO}_{2}(26 \%)$ em relação ao $\mathrm{Al}_{2} \mathrm{O}_{3}(0,51 \%)$ (tabela 5). Isso pode refletir uma cimentação de sílica dessa rocha pois, em ambientes marinhos, a silício dos tetraedros pode sofrer substituição e a sílica deslocada pode vir a se precipitar como agente cimentante (Hower et al., 1976 e Boles \& Franke, 1979, citados por Roberson et al., 1981).

$\mathrm{O}$ motivo para grande variação de Ki nestes solos de mina não é muito claro, mas pode estar relacionada com a heterogeneidade do material de origem. Vale ressaltar que a amostra direcionada à análise é homogeneizada, porém a fração menor que $2 \mathrm{~mm}$ possui fragmentes de rochas em diferentes estágios de alteração que são considerados como TFSA em decorrência de sua granulometria. Portanto a variação de 
elementos na análise pode ser devido maior ou menor quantidade destes fragmentos que podem ser constituídos de calcário+sílex, sílica amorfa, folhelhos com diferentes graus de cimentação e diferentes argilitos e siltito.

Mesmo na fração argila que sofreu ataque sulfúrico e alcalino possivelmente ocorrem diferentes concentrações de cimento silicoso ou mesmo diferentes graus de substituição isomórficas, o que pode implicar na variabilidade dos teores de $\mathrm{SiO}_{2}$ e $\mathrm{Al}_{2} \mathrm{O}_{3}$ e portanto de $\mathrm{Ki}$.

Comparando-se os perfis P2 (15 anos) e P3, P4 e P5 (32 anos), abertos em áreas onde predominam fragmentos rochosos de calcário+silex e folhelhos pirobetuminosos, pode-se perceber os maiores valores de $\mathrm{Al}_{2} \mathrm{O}_{3}$ frequentemente ocorrem nas áreas mais velhas, tanto na fração TFSA quanto na fração argila.

$\mathrm{O}$ perfil $\mathrm{P} 1$ ( 2 anos) possui maiores teores de $\mathrm{Al}_{2} \mathrm{O}_{3}$ em relação aos demais mais velhos, porém esse perfil está situado em um monte que recebeu materiais argilosos do subsolo, argilitos e siltitos, sendo que estes representavam um maior volume no banco de deposição que os fragmentos rochosos de calcário+silex e folhelhos. Esse perfil também apresentou-se com um Ki próximo aos do solo encontrados na região (Telles 1997 e Calero-Marino, 1999).

O Kr varia de 2,13 a 10,08 na fração TFSA e 2,55 a 12,98 na fração argila. $\mathrm{O}$ índice $\mathrm{Kr}$ aparentemente não apresenta relação com a idade destes solos de mina, nem com a profundidade do perfil. 


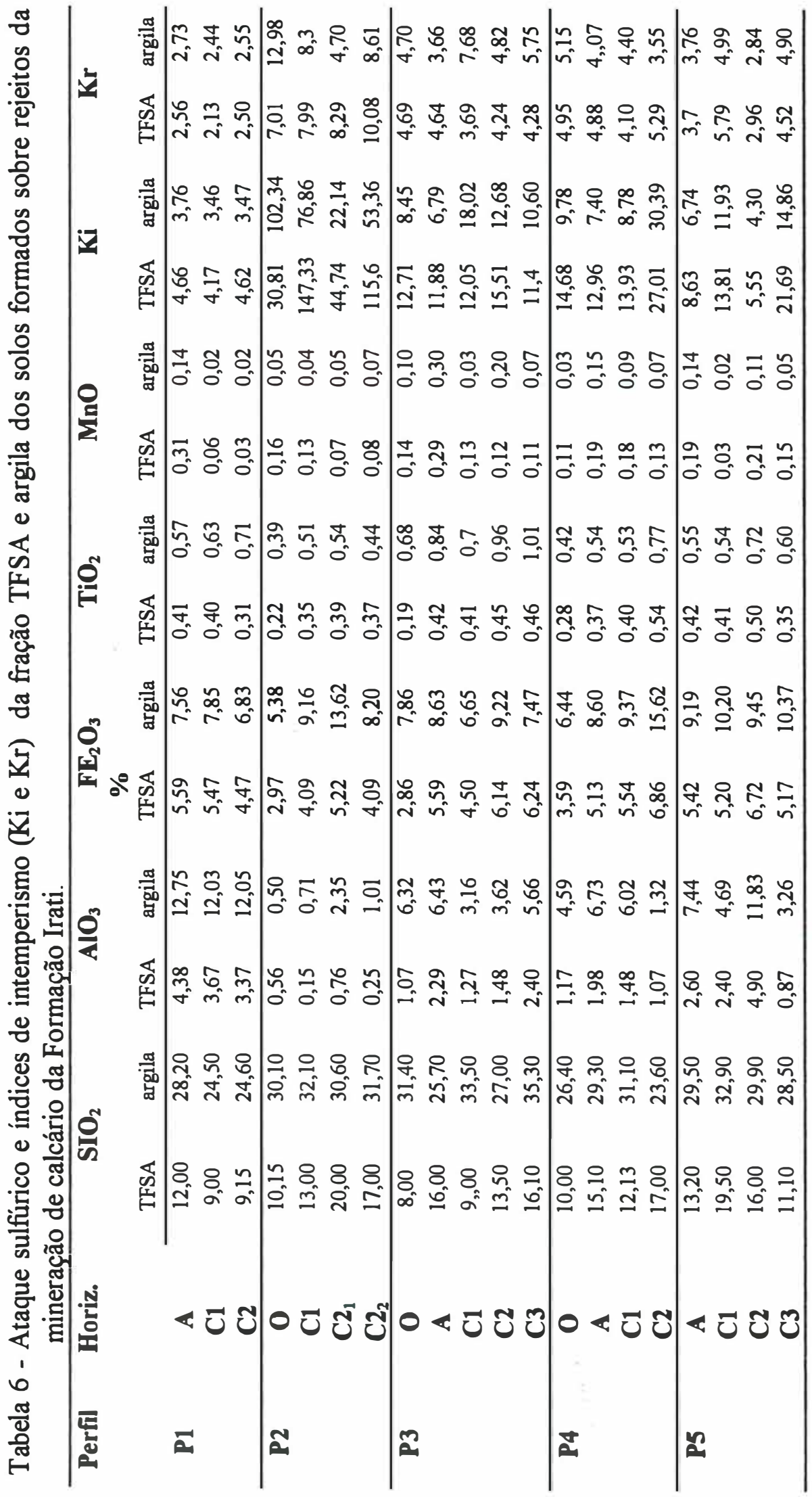




\subsection{Mineralogia}

As análises mineralógicas realizadas indicam que os minerais encontrados nestes solos de mina em formação refletem os minerais do material de origem que constituem o rejeito da atividade de mineração. É constituído por uma mineralogia simples com sílica amorfa e quartzo predominando na fração areia e na fração argila, a esmectita é o mineral mais representativo.

Com o intuito de se caracterizar mineralogicamente os rejeitos e de observar possíveis ocorrências de alterações dos materiais nos bancos em função do tempo de exposição, foi feita uma caracterização das frações areia, silte e argila de cada horizonte dos perfis P1, P2, P3, P4 e P5, abertos nos montes de 2, 15 e 32 anos. Apresenta-se a seguir as determinações mineralógicas realizadas.

\subsubsection{Observações da fração areia feitas em lupa binocular e no microscópio petrográfico}

A fração areia dos solos formados a partir dos rejeitos da mineração do calcário Irati é composta basicamente de lito-relíquias das rochas em vários estágios de alteração como os folhelhos, calcários e sílex. Foram observadas eventualmente na fração areia concreções ferruginosas provavelmente herdadas dos solos que outrora cobriam a área e foram removidos para a operação da mineração.

$\mathrm{Na}$ fração areia muito fina notou-se a predominância de micro-agregados silicosos associados à impurezas e quartzo. Estes micro-agregados, juntamente com o quartzo, frequentemente assumem valores superiores a $97 \%$ dos grãos da areia muito fina. Os feldspatos, hematita e a mica aparecem com freqüência muito reduzida em comparação aos primeiros (tabela 7).

Os micro-agragados resistiram ao tratamento de oxidação da matéria orgânica e de deferrificação feitas para análises mineralógicas, provavelmente devido ao cimento silicoso que pode vir a se precipitar durante o processo de formação de ilita a partir da esmectita nos folhelhos em ambientes marinhos (Hower et al., 1976; Boles \& Franks citados por Roberson et al., 1981). 
Através da análise em microscópio petrográfico da areia fina, pôde-se evidenciar que carapaças fósseis aparecem em P1 ( 2 anos). Esse perfil é constituído de volumes argilosos mesclados aos fragmentos de folhelhos e calcário. Essas carapaças também foram encontradas no horizonte $\mathrm{C} 2$ de $\mathrm{P} 5$ ( 32 anos) e pode ser uma evidência de que este horizonte difere dos demais no mesmo perfil provavelmente devido à deposição de camadas heterogêneas. Schafer et al. (1980) e Ciolkosz et al. (1985) relatam que a deposição de camadas heterogêneas é comum em solo de mina. 


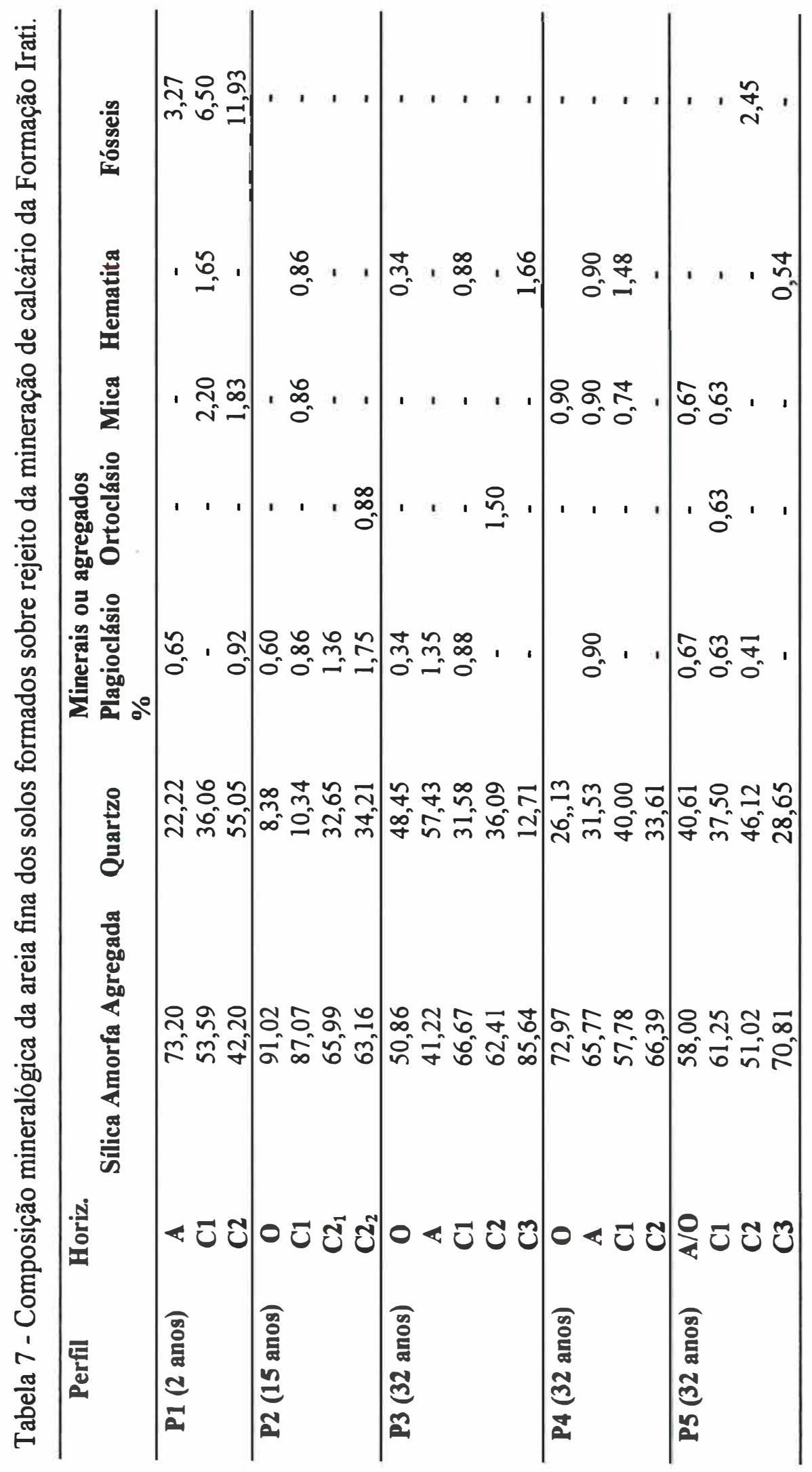




\subsubsection{Difratometria de raios-X}

Embora evidentes na fração areia e cascalho e silte, os carbonatos de $\mathrm{Ca} e$ $\mathrm{Mg}$, bem como o gesso não foram evidenciados nos difratogramas das amostras de solo tratadas pois, o ataque aos carbonatos e as sucessivas lavagens eliminaram estes minerais. Contudo os carbonatos foram evidenciados nos difratogramas do pó das rochas que constituem o material de origem e os sais solúveis foram identificados através dos difratogramas do pó não tratado dos precipitados que cobrem as rochas na parede dos perfis na forma de eflorescências (figura 64).

A eflorescência branca que envolve a superficie das rochas e raízes e ocupa alguns espaços porosos (ver foto $5 \mathrm{~B}$ na página 49) é constituída por precipitados de $\mathrm{CaSO}_{4}$ que formam cristais aciculares de gipso, identificados pelos espaçamentos de $7,56,5,27$ e $3,80 \AA$ (figura 64 ).

Eflorescências de coloração amarelada, que aparecem como precipitados pulverulentos na superficie dos folhelhos em alteração e entre suas placas (foto 5 B na página 55), foram identificados como natrojarosita pelos espaçamentos de 5,94, 5,57, $5,05,3,12,3,06,2,96,2,78,2,53,2,24,1,98,1,83 \AA$ (figura 64).

A natrojarosita, formada como produto da oxidação da pirita, também foi evidenciada por Mermut et al. (1985) mm solos desenvolvidos sobre folhelhos marinhos do Cretácio. Kämpf et al. (1997), encontraram tal mineral os precursores de tal mineral, que apareciam na forma de eflorescências nas faces expostas do perfil aberto sobre rejeitos formados por folhelhos carbonosos e carvão no Rio Grande do Sul.

$\mathrm{O}$ pó das principais rochas retiradas da frente de lavra e que formam o rejeito da mineração do calcário Irati, após os tratamentos de oxidação da matéria orgânica e deferrificação, foi analisado por difratometria de raios-X (figura 65), obtendose:

a) no calcário encontra-se a dolomita com espaçamentos de 2,98, 2,67, $2,54,2,19,2,01,1,78 \AA$.

b) no folhelho pirobetuminoso encontram-se o quartzo com principais espaçamentos a 4,27, 3,34, 2,44, 2,27, 2,23, 2,11, 1,97, 1,81, 1,78, 1,66 $\AA$, seguido de 
plagioclásio com menor intensidade e de espaçamentos $4,04,3,78,3,20,2,94,3,64 \AA$, ortoclásio $(3,78,3,26,3,22,2,94 \AA)$ e esmectita $14 \AA$.

c) no siltito acinzentado encontram-se o quartzo, seguindo-se o plagioclásio e o ortoclásio.

Comparando-se os difratogramas do material de origem (figura 65) com os obtidos da fração silte e argila dos solos de mina aqui estudados (figuras 66 a 75), pode-se evidenciar que sua mineralogia reflete a do material de origem constituinte do rejeito, principalmente a dos folhelhos.

Os difratogramas da fração silte dos solos de mina (figuras 66 a 70), revelam que o quartzo, é o mineral mais abundante nestes solos de mina. Além do quartzo, comum em todos os perfis, ocorrem também os feldspatos, que apresenta picos de difração de menor intensidade, em relação ao quartzo.

Dentro do grupo dos feldspatos, o plagioclásio parece prevalecer sobre o ortoclásio. No entanto, nos perfis mais recentes Pl (2 anos), que contém um material diferenciado dos demais e P2 (15 anos), o ortoclásio apresenta-se com picos de difração mais intensos, mas não chegam a se eqüivaler aos picos dos plagioclásios (figura $66 \mathrm{e}$ 67).

Calero-Marino (1999) também encontrou quartzo e feldspatos na fração silte dos solos naturais formados sobre a formação Irati. Além destes minerais, o autor também relata a presença de mica nesta fração. Apesar deste mineral ser observado nos horizontes superficiais dos solos de mina pelas micrografias (ver micrografia $1 \mathrm{D}$ e seu respectivo pico espectral - figuras 76D) não ficou clara a evidência dos picos de difração da mical no difratograma da fração silte no presente estudo.

Contudo, a mica, possivelmente a ilita, foi observada nos difratogramas da fração argila como discutido a seguir com observações feitas sobre os difratogramas apresentados nas figuras 71 a 75 . 


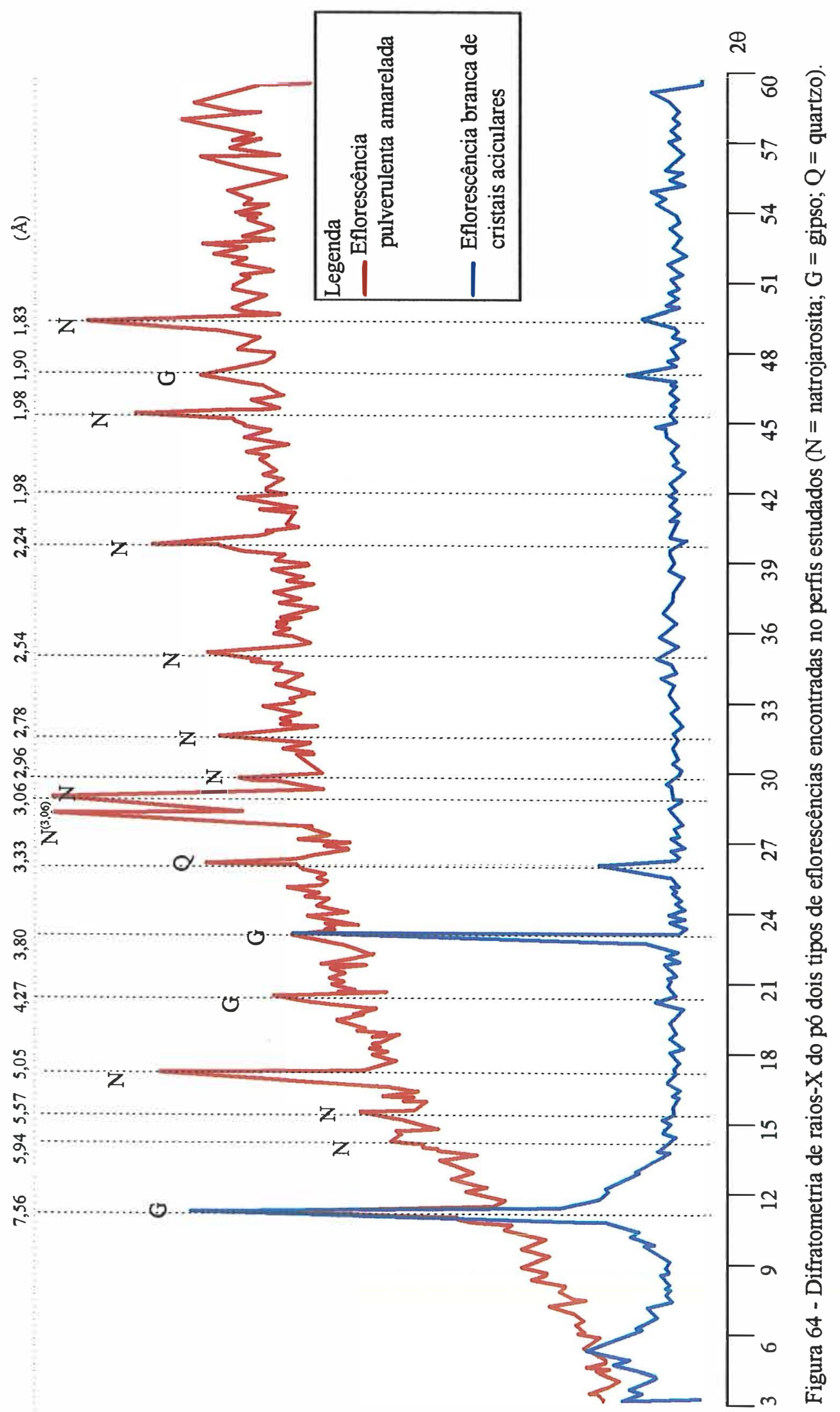




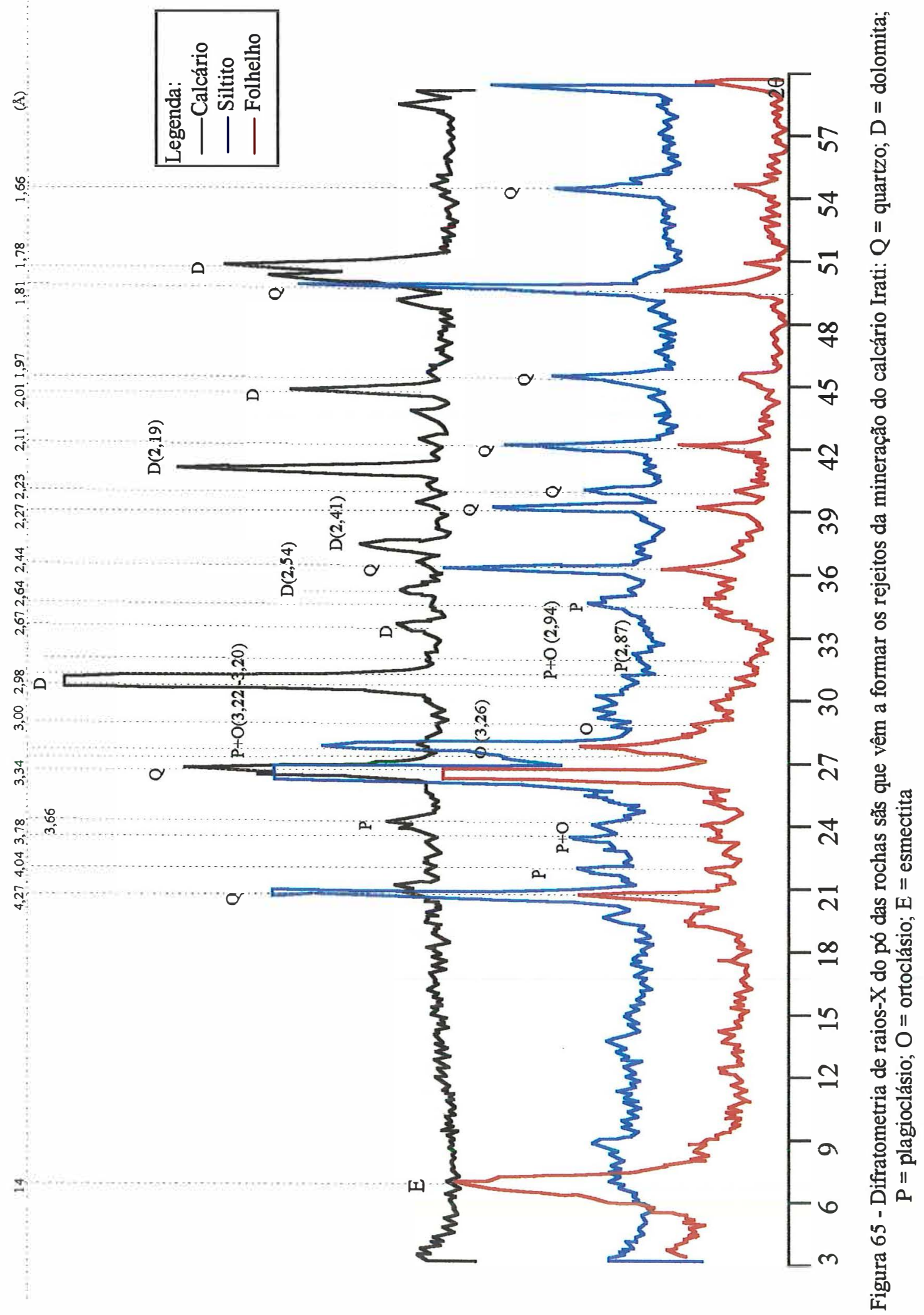


A esmectita é o mineral mais representativo na fração argila destes solos de mina e é representada por picos de difração muito intensos e mais freqüentes a $12,64 \AA$ no tratamento com $\mathrm{K}$, expandindo a $14,73 \AA$ quando saturada com Mg à temperatura ambiente e, quando o tratamento com $\mathrm{Mg}$ e solvatado com etileno glicol, frequentemente se expande a $16,99 \AA$.

Subamostras de argila saturadas com $\mathrm{K}$ e submetidas à aquecimento de $350^{\circ} \mathrm{C}$, apresentam espaçamentos que variam entre 10,04 a $11,78 \AA$ que pode ser um indicativo de interestratificados mica-esmectita. Finalmente quando a argila saturada com $\mathrm{K}$ é submetida a aquecimento de $550^{\circ} \mathrm{C}$ ocorre destruição da estrutura esmectita, restando os espaçamentos de 10,04 e 5,01 Å referentes à ilita.

Moniz et al. (1995) também encontraram esmectitas em sedimentos da formação Irati. Calero-Marino (1999) comenta que a esmectita encontrada em solos oriundos de sedimentos da Formação Irati pode se tratar de nontronita devido às concentração de ferro que podem ocupar as camadas octraedrais.

Além da esmectita, a haloisita aparece com maior intensidade nos horizontes superficiais de P2 (15 anos) P3, P4 e P5 (32 anos) e é identificada através dos espaçamentos de 7,19 e $3,45 \AA$ (figuras 72 a 75), contudo, este mineral apresenta pouca intensidade ou não se pronuncia em horizontes mais profundos. A haloisita também não é evidenciado no perfil mais recente $\mathrm{P} 1$, aberto na área de 2 anos de idade.

A piritamuitas vezas observada no material e retratada na foto $4 \mathrm{~B}$ (página 48) e nas micrografias $2 \mathrm{~B}$ e $2 \mathrm{C}$ e identificada por seus respectivos picos espectrais (figuras $77 \mathrm{~B}$ e 77C), não foi evidenciada pela análise de difratometria de raios-X. Possivelmente o processo de oxidação da matéria orgânica, via úmida à quente, possa ter oxidado este mineral. 


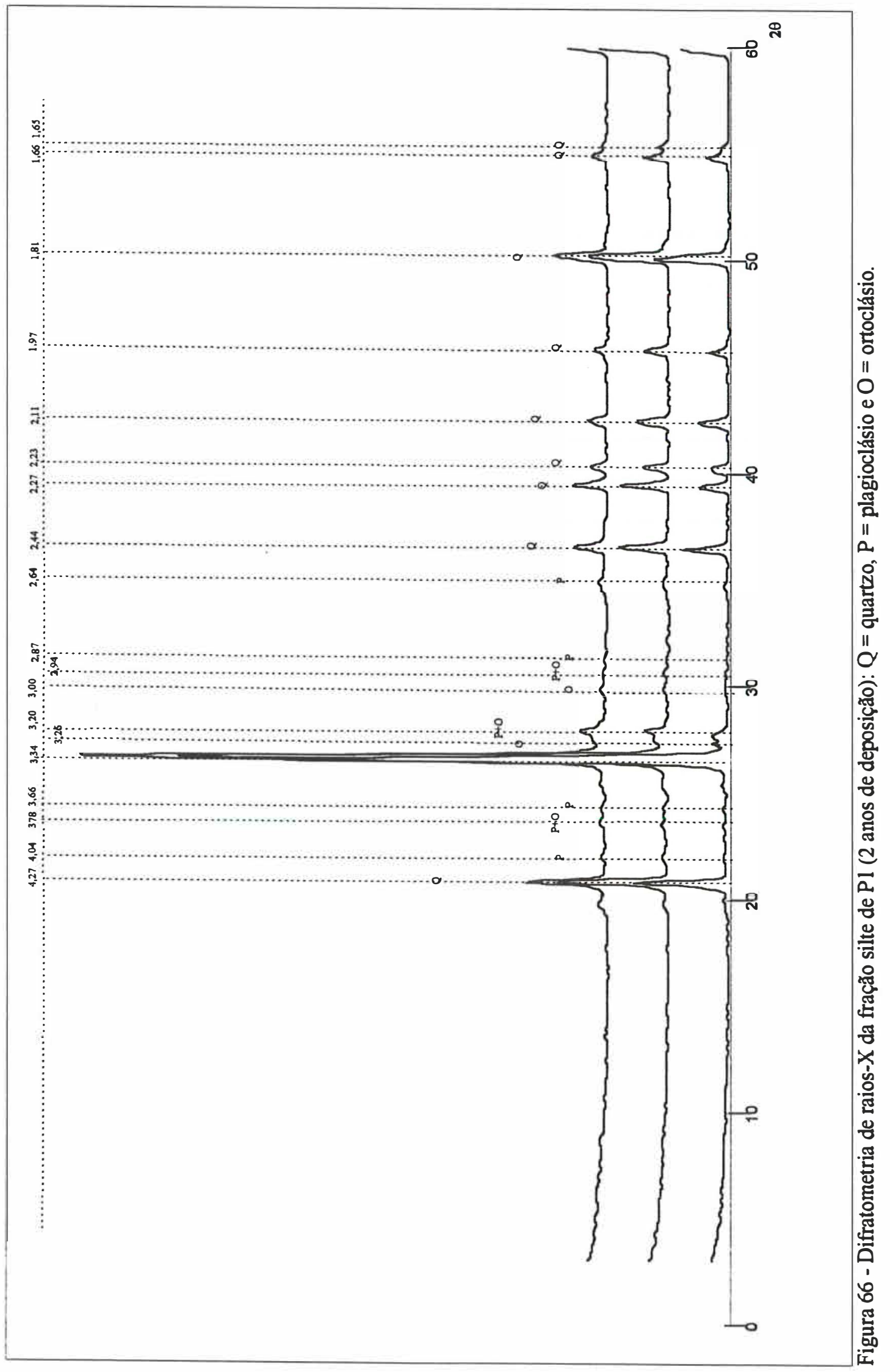




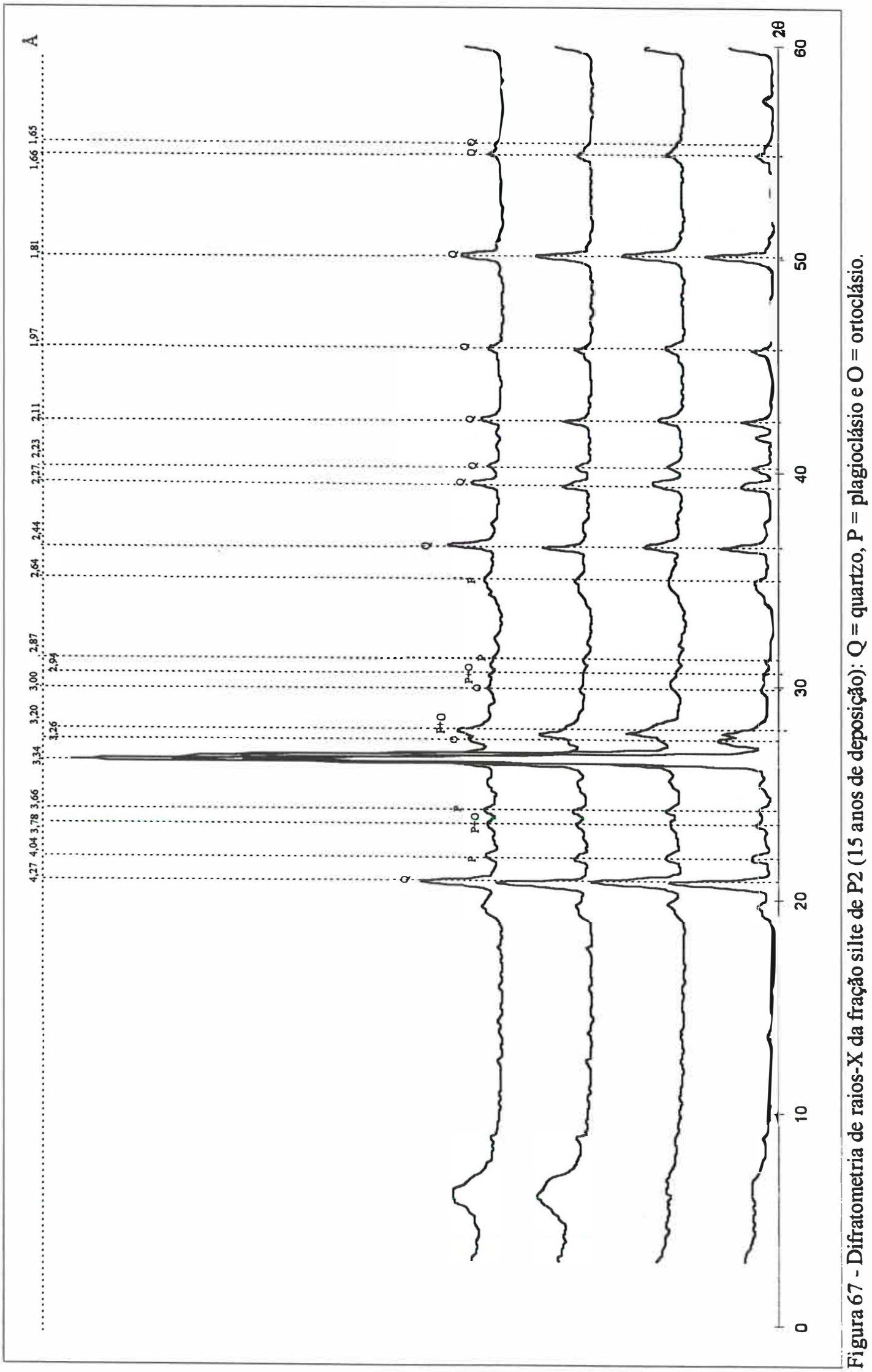




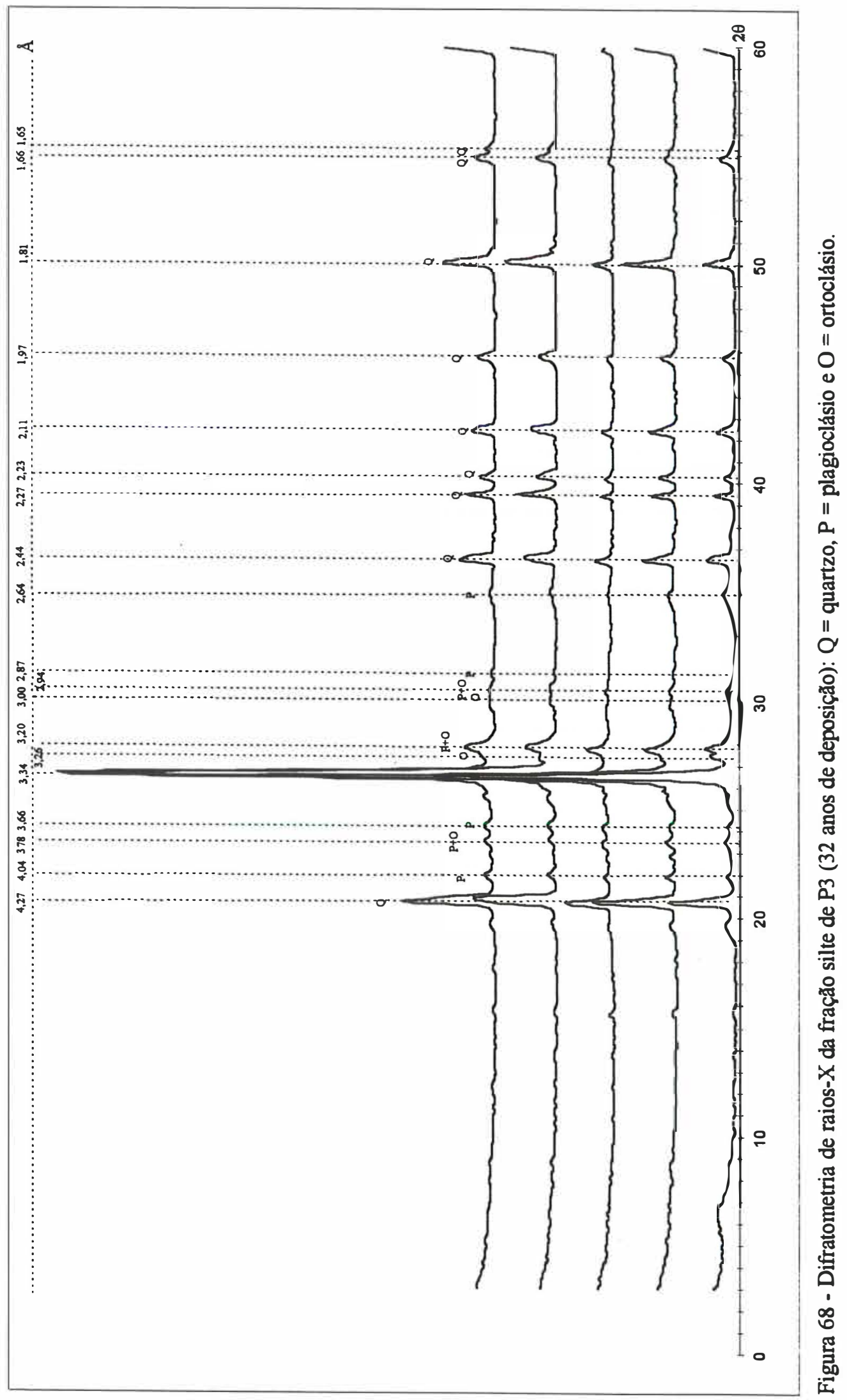




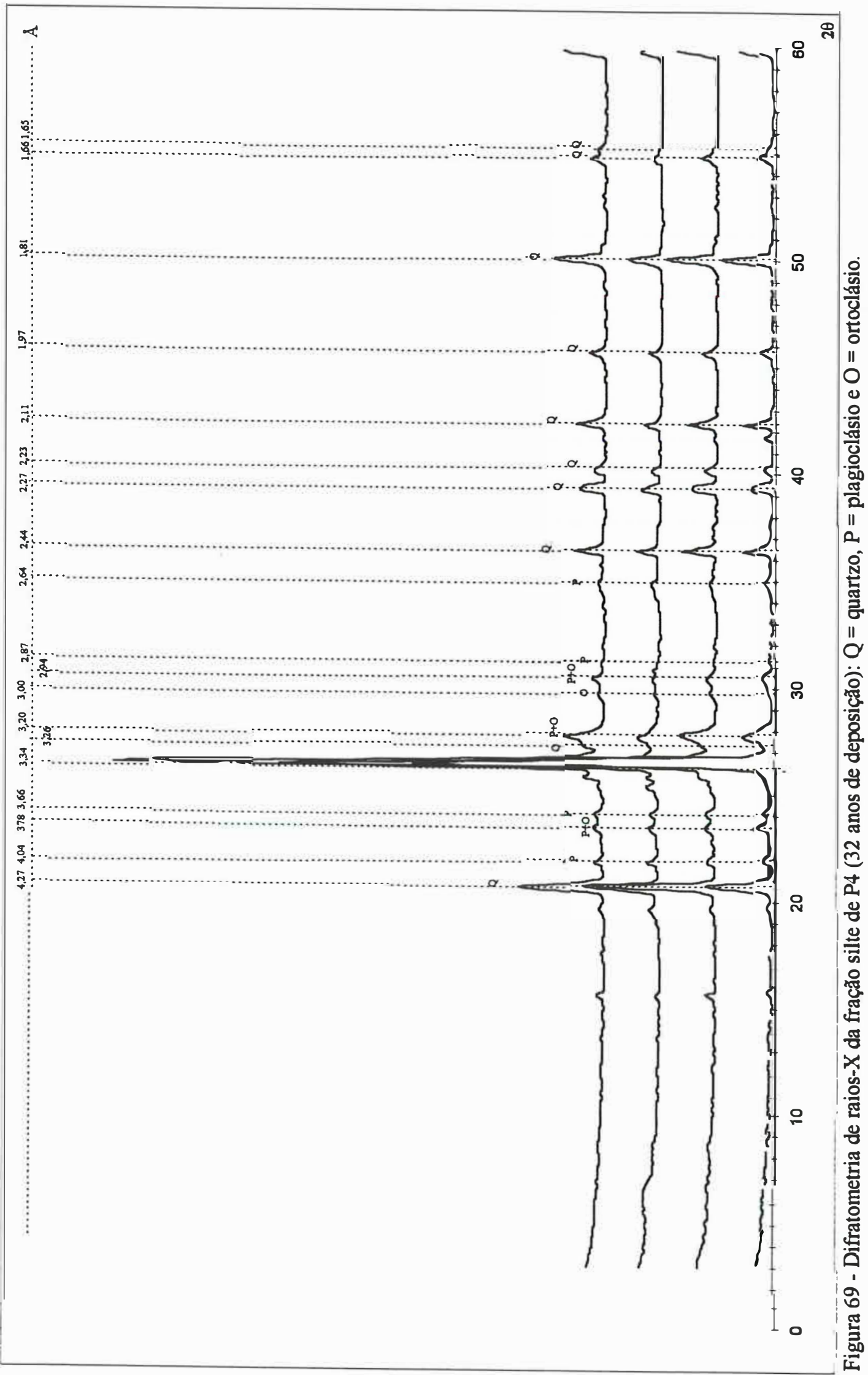




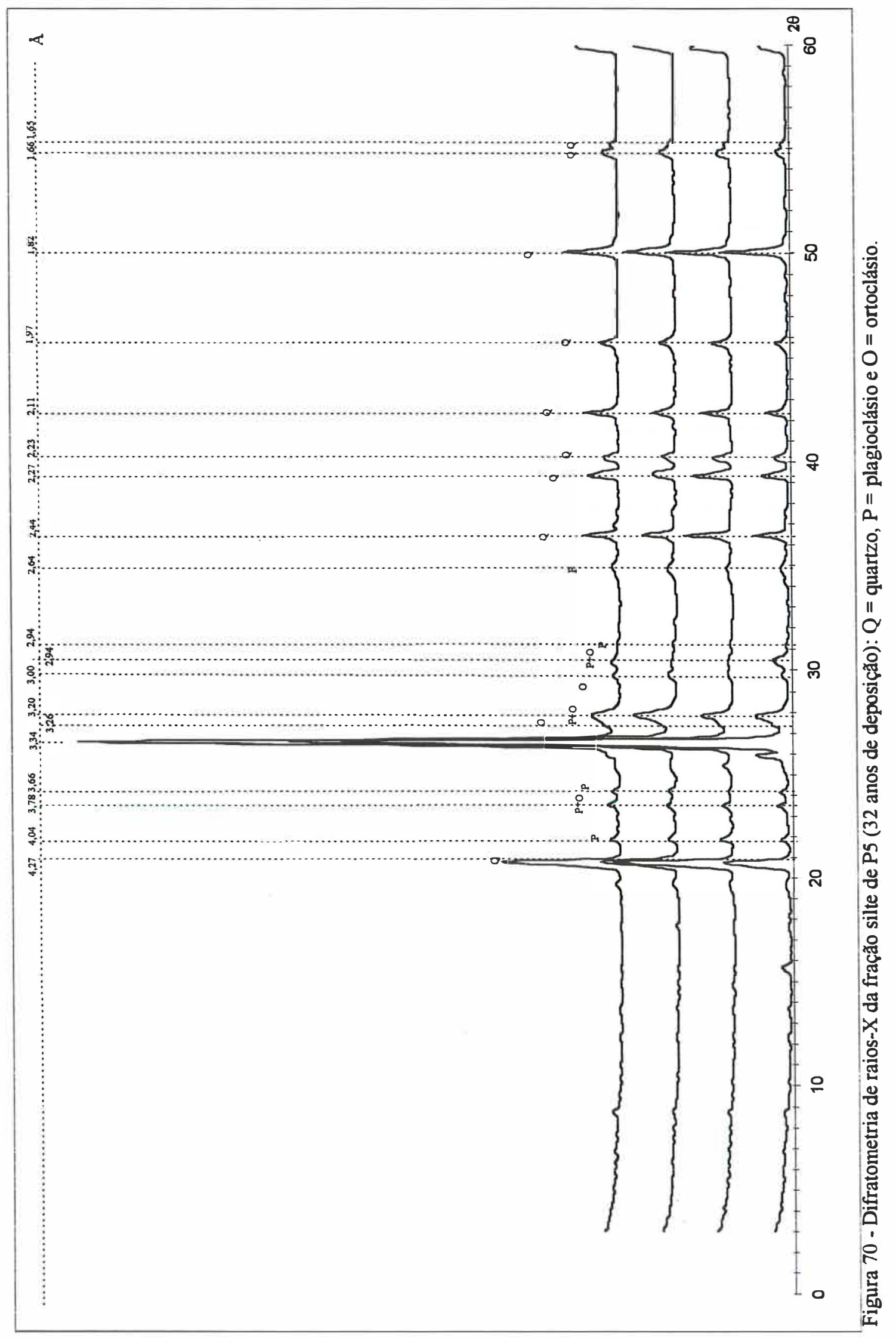




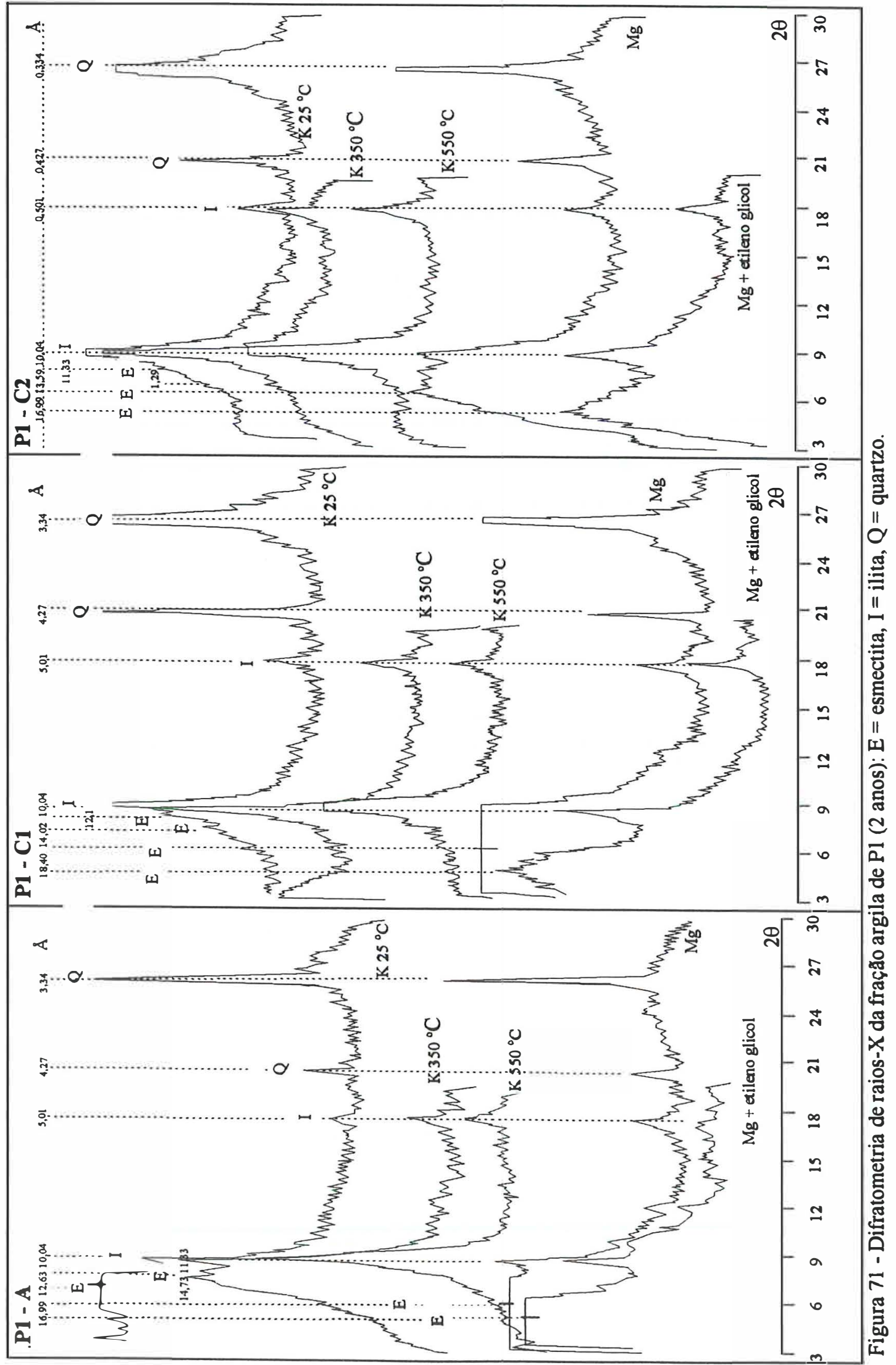




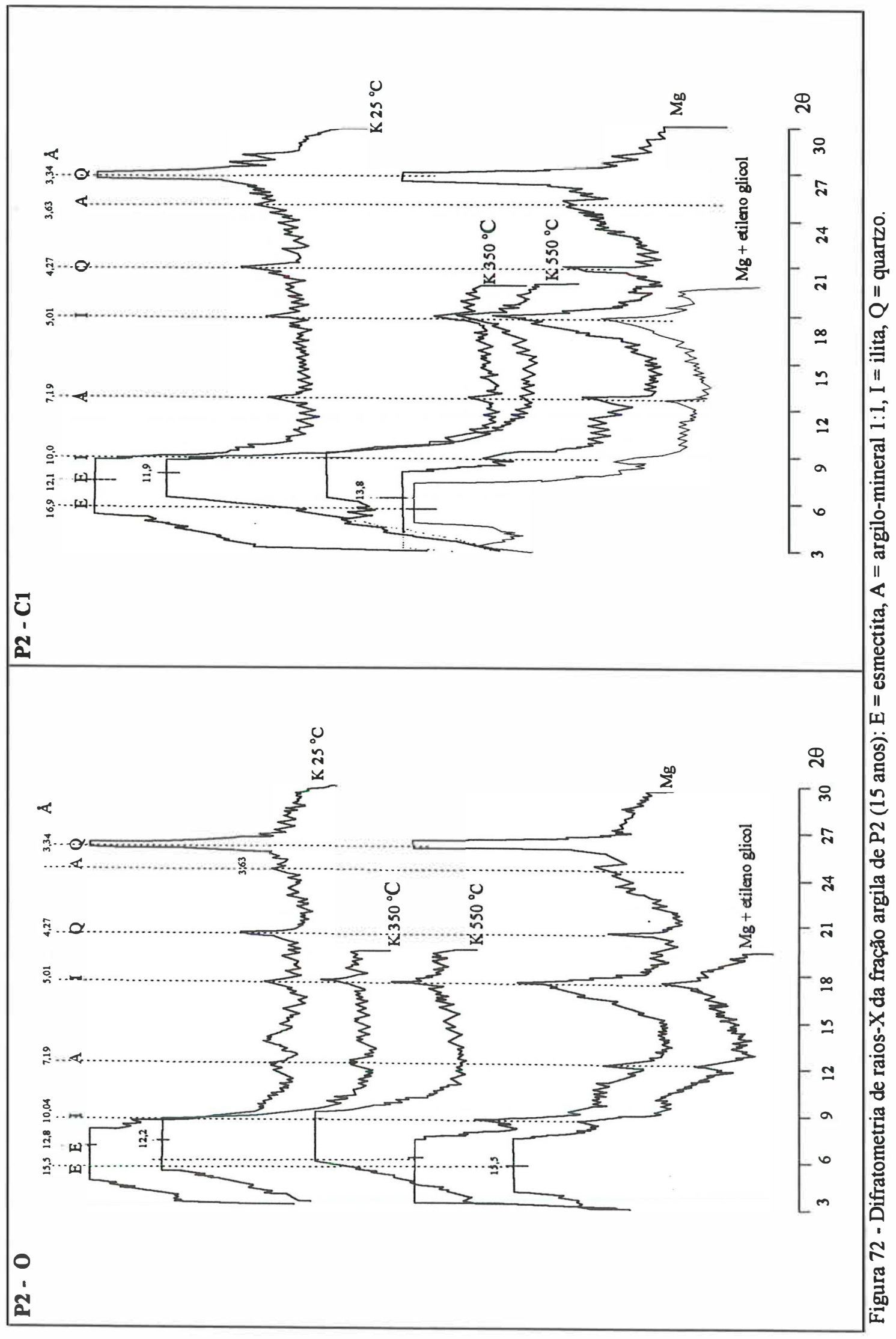




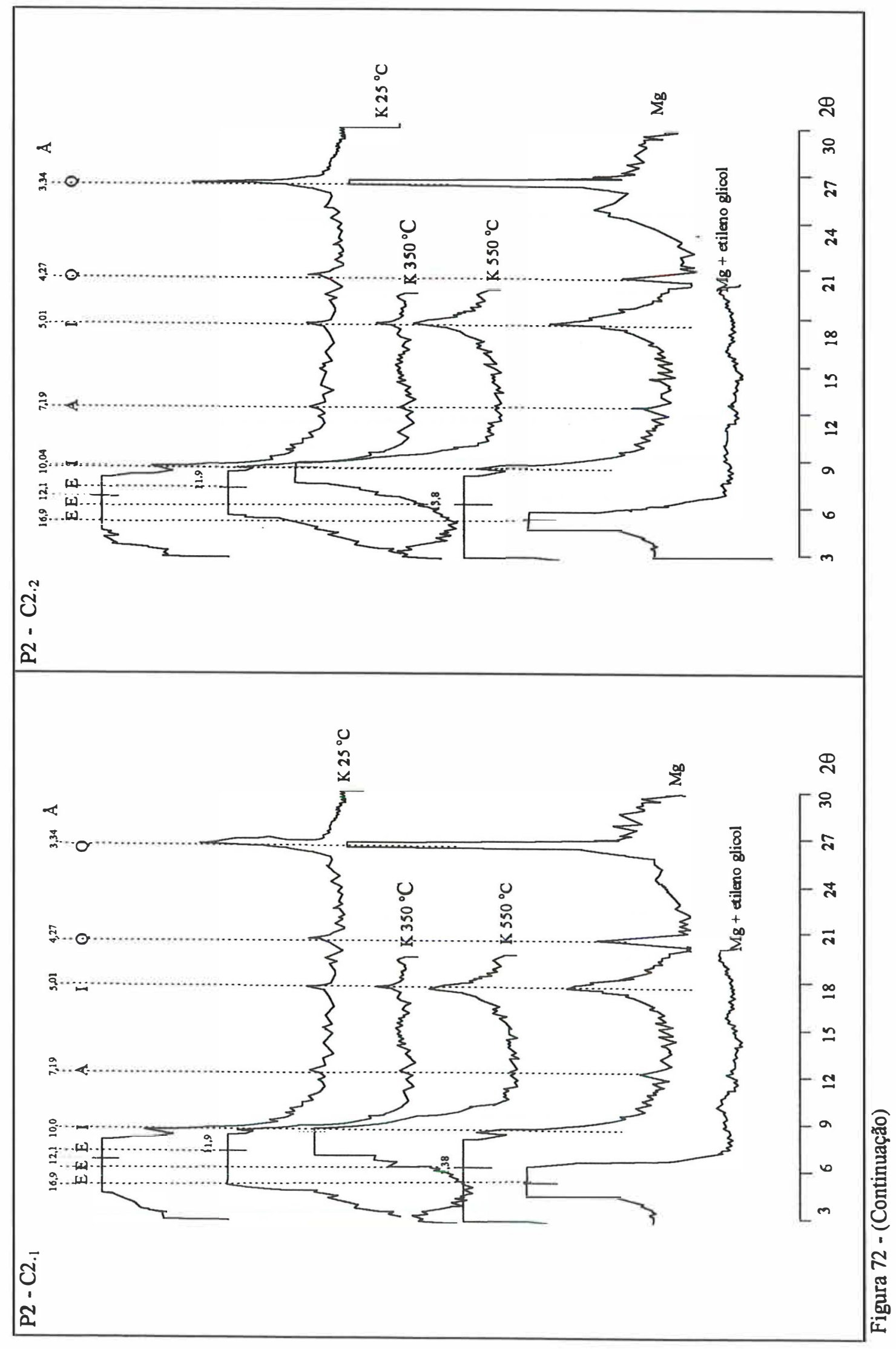




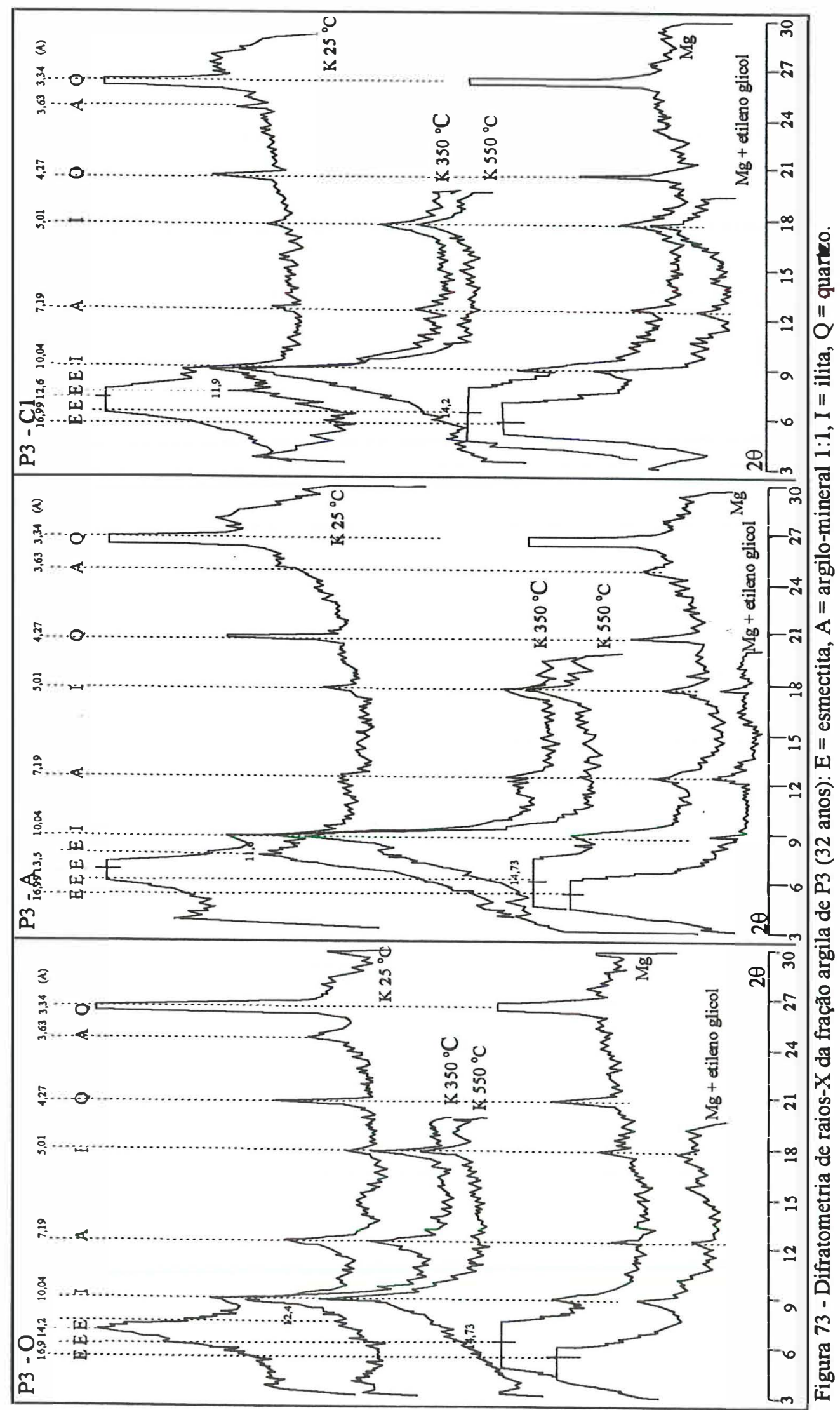




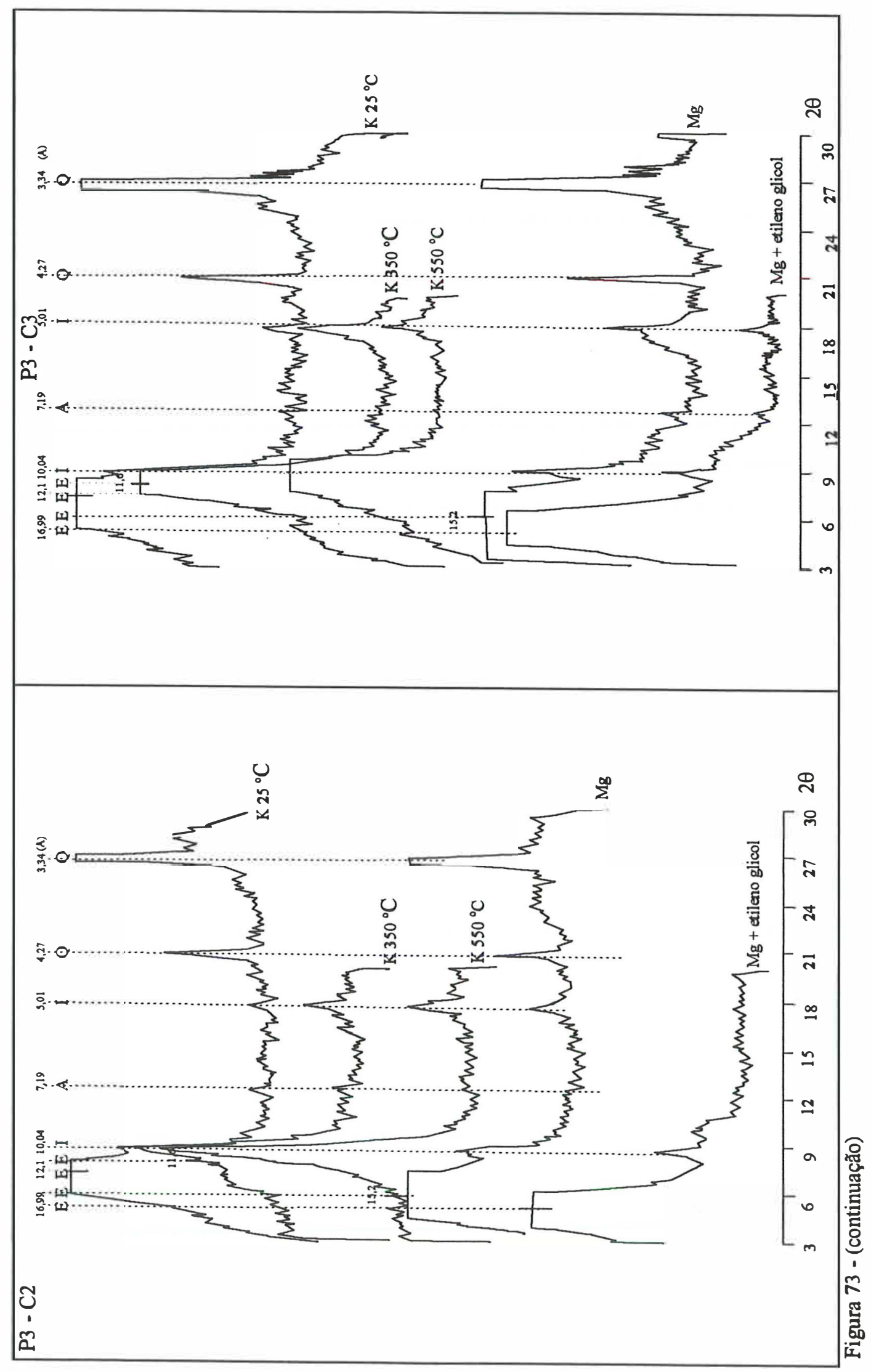




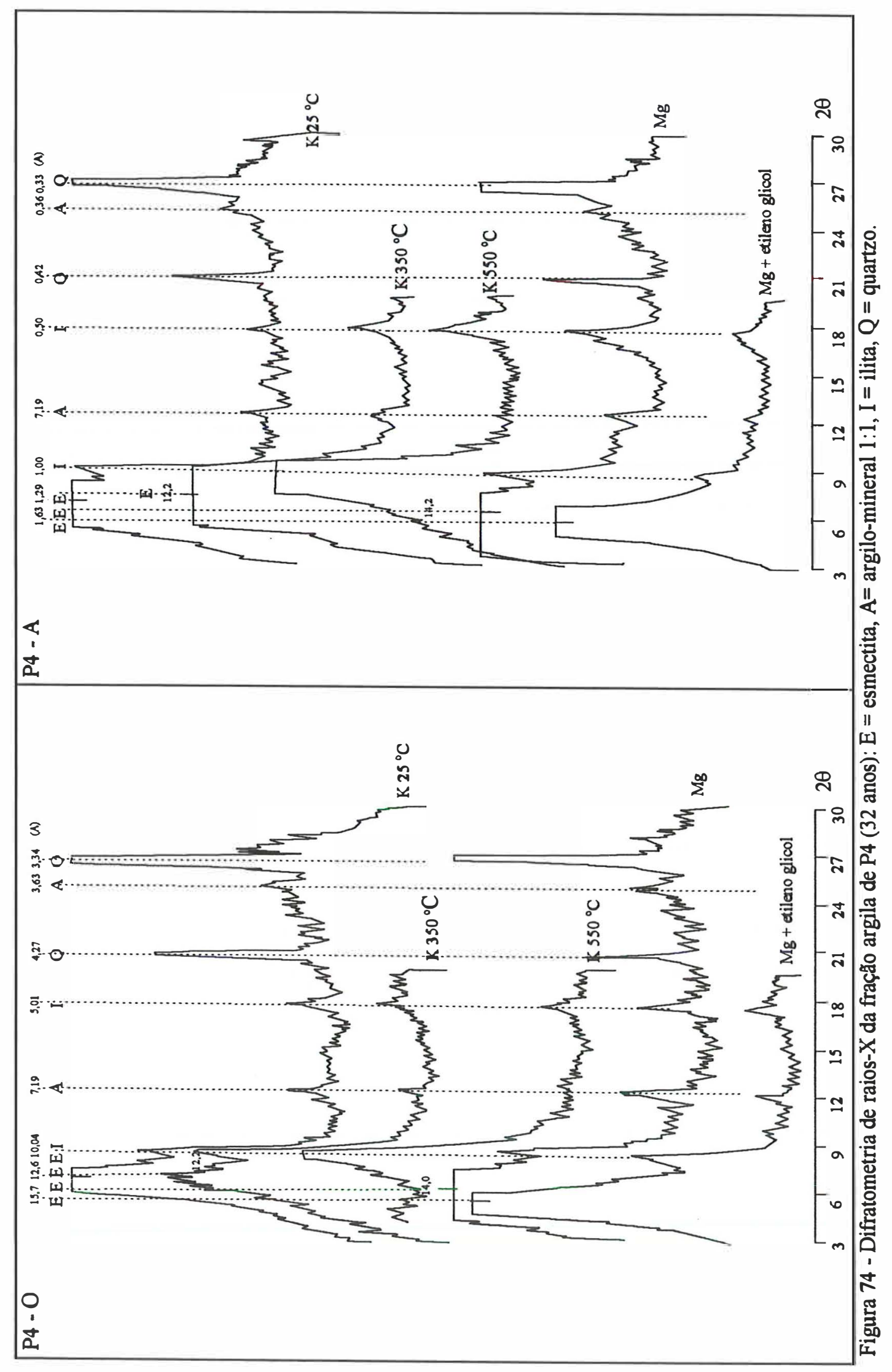




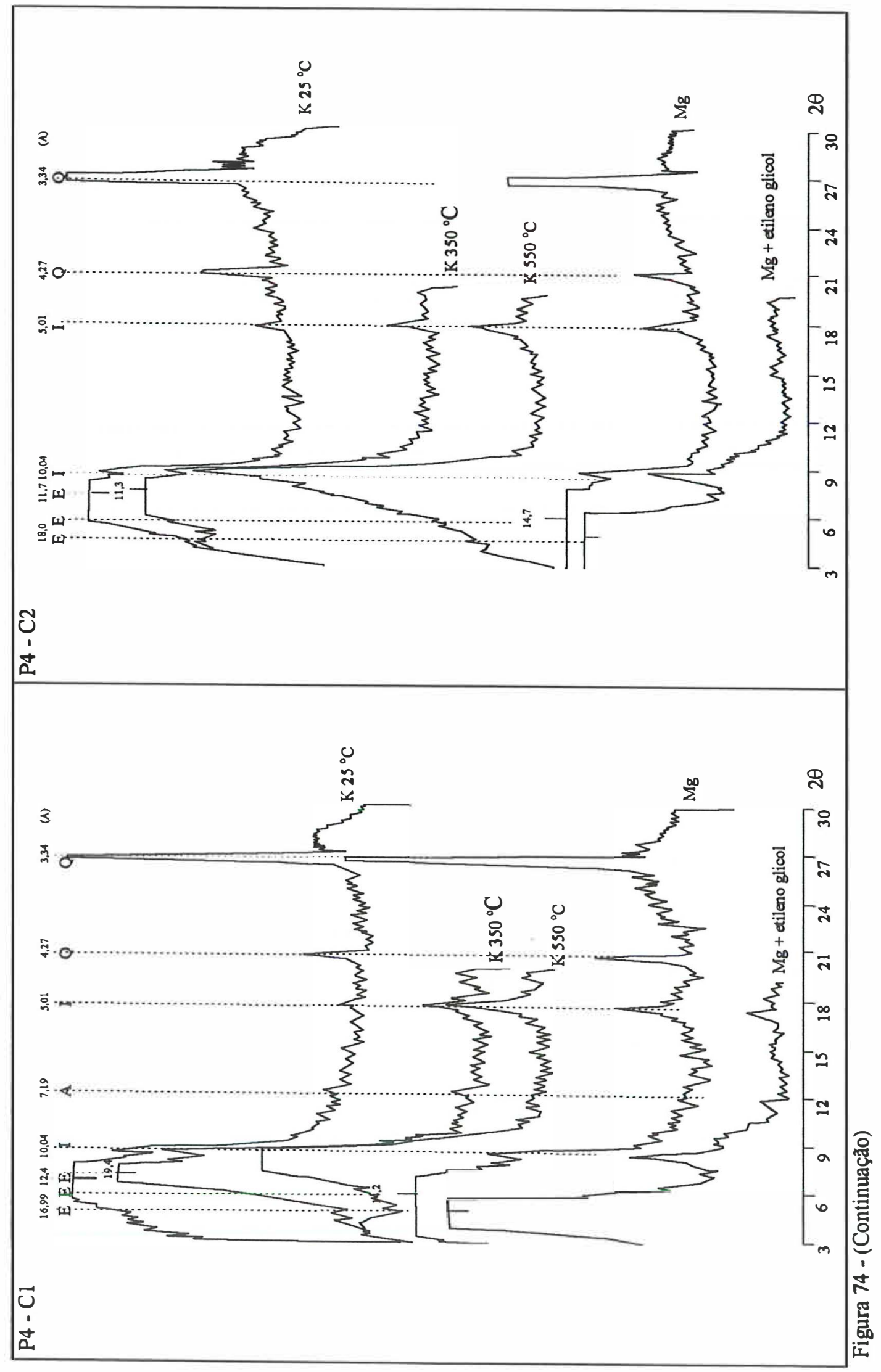




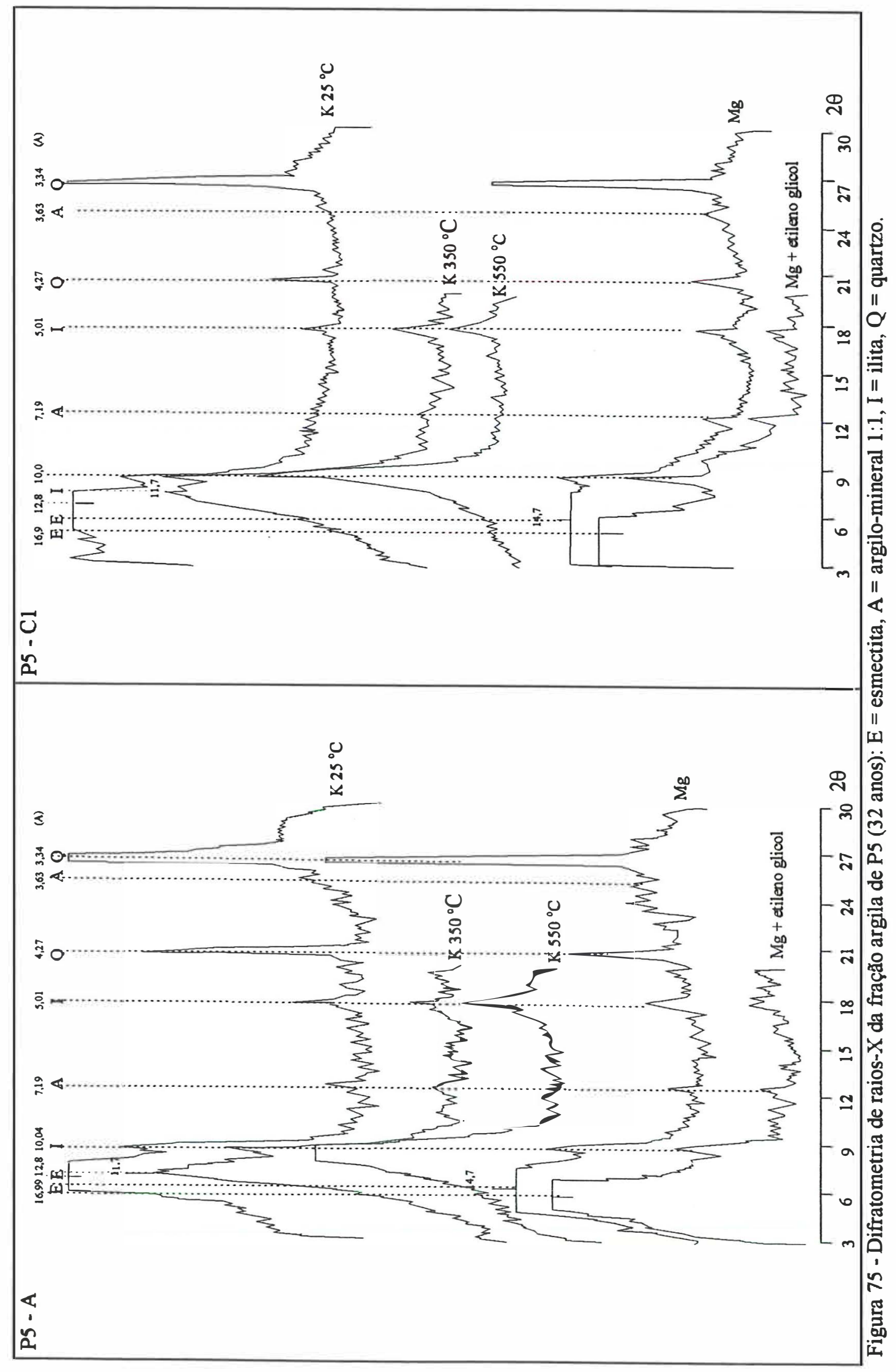




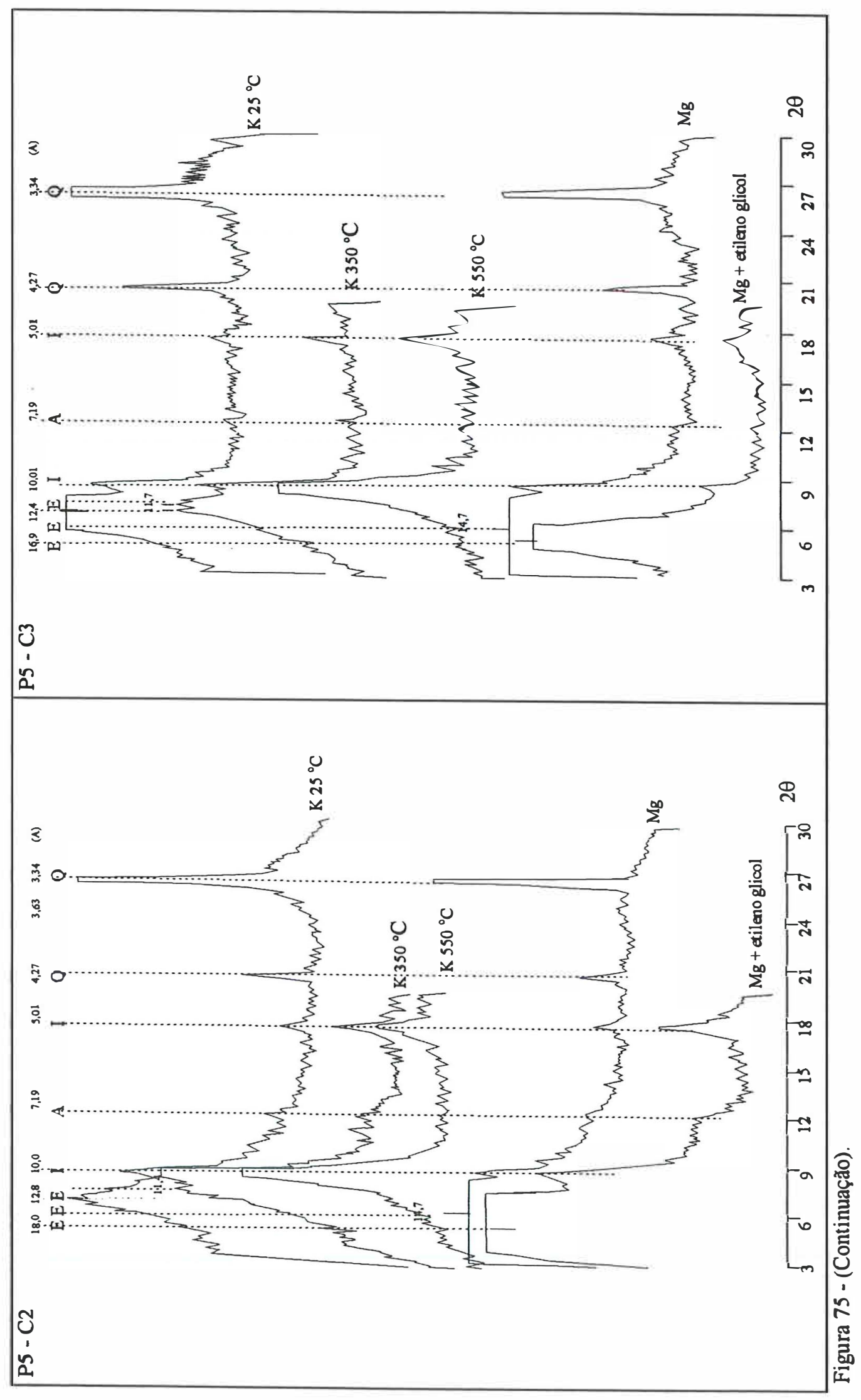




\subsubsection{Observações micrográficas dos horizontes minerais superficiais}

Através de observações feitas em microscópio eletrônico de varredura, pôde-se constatar a presença mica, matrizes calcíticas e dolomíticas e pirita que não foram identificados pela difratometria de raios- $\mathrm{X}$. Estes minerais são comuns à todos os perfis e são ilustrados pelas micrografias 1 e 2 e confirmados por seus picos espectrais (figuras 76 e 77).

A micrografia 1A retrata a ocorrência de crostas ferruginosas na superficie de fragmentos folhelhos carbonosos pirobetuminoso. Estas crostas se formam devido a oxidação destes fragmentos e o ferro é confirmado por seu pico espectral (figura $76 \mathrm{~A}$ ). A oxidação do ferro pode acontecer em impurezas do complexo carbonato e em agentes ferro-cimentantes encontrados nos rejeito reduzido e é um dos primeiros processos de alteração que sofrem os materiais de rejeitos expostos às novas condição de superficie (Roberts et al., 1988 b).

Entre as placas de esfoliação dos folhelhos, no horizonte $\mathrm{C} 1$ do perfil $\mathrm{P} 2$ (15 anos), encontram-se micro-agregados, provavelmente orgânicos e seus espectros indicam a presença de $\mathrm{Ca}, \mathrm{Mg}, \mathrm{K}$ e $\mathrm{P}$, além de $\mathrm{Si}$ e $\mathrm{Fe}$ (micrografia 1B e figura 76B). Estes agregados ricos em nutrientes parecem ser interceptados por estruturas lineares, provavelmente hifas fúngicas, sofrendo alterações (micrografia 1C e figura $76 \mathrm{C}$ ).

A mica, presente em todos os perfis, é identificada por sua morfologia através da micrografia $1 \mathrm{D}$ e confirmada por seu pico espectral (figura 76D) no perfil P2 (15 anos).

Microcristais de pirita e mica, presentes em todos os perfis, ainda são bem evidentes nos horizontes superficiais das áreas mais antigas. A micrografia $2 \mathrm{~A}$ e a figura 77A retrata a pirita no horizonte A de $\mathrm{P} 3$.

Fragmentos com matriz dolomítica e calcítica, também presentes em todos os perfis , são retratados nos perfil P4 (32 anos) através da micrografia 2B e 2C e de seus picos espectrais (figura 77B e 77C, respectivamente). Ainda em P4 observa-se a presença de um mineral amorfo rico em fósforo (micrografia 2D e figura $77 \mathrm{D}$ ). 

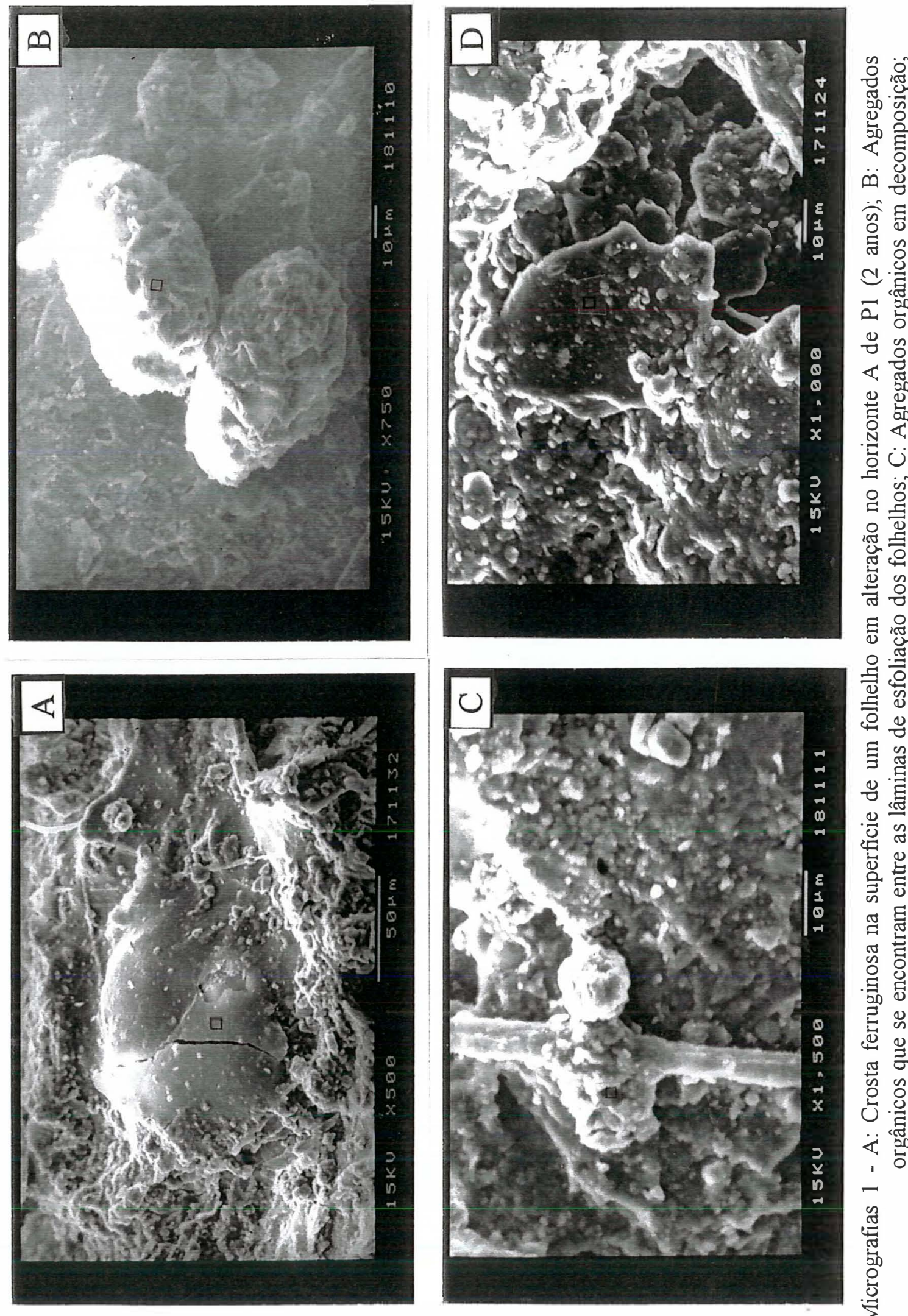

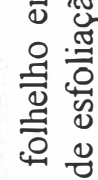

छ ฮ

记氞

包 䨌

屯气

芯 덩

콜

๙

열잉

胥.

的

๘

苞

旡正

¿

告 


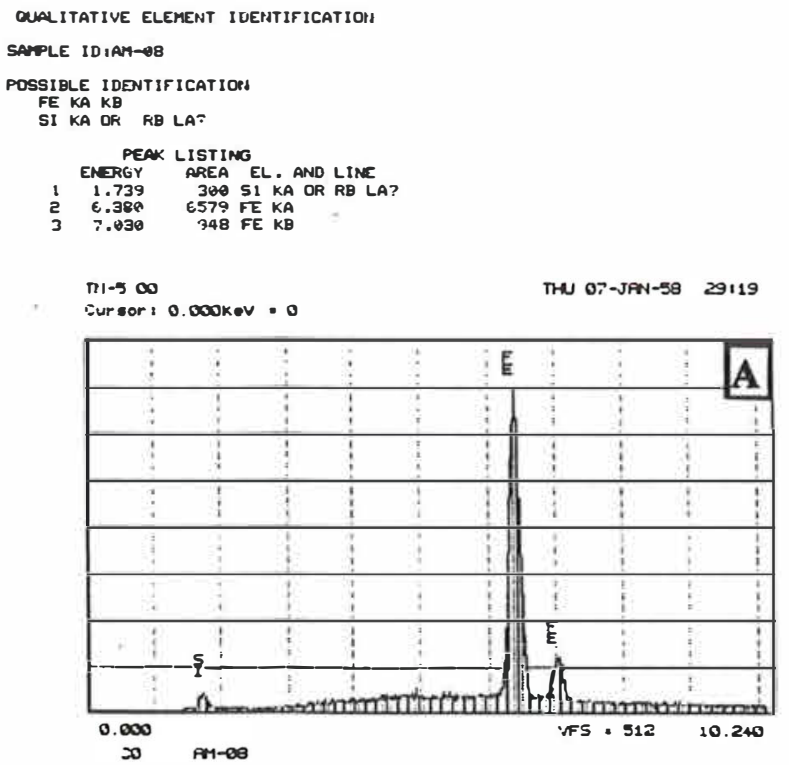

DUALITATIVE ELEMENT IDESTIFICATIOH

SAMPLE ID:AM-OOS

POSSIBLE IDENTIFICATION

CA KA KB

$P$ KA OR IR LAF
3 KA OR MO LA? OR TL MA
MG KA OR AS LA?

SI KA OR AS LA

$K$ KA OR IN LA?

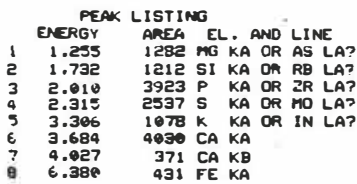

$n i-\infty$

rurseor, 0.000kev . 0

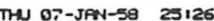

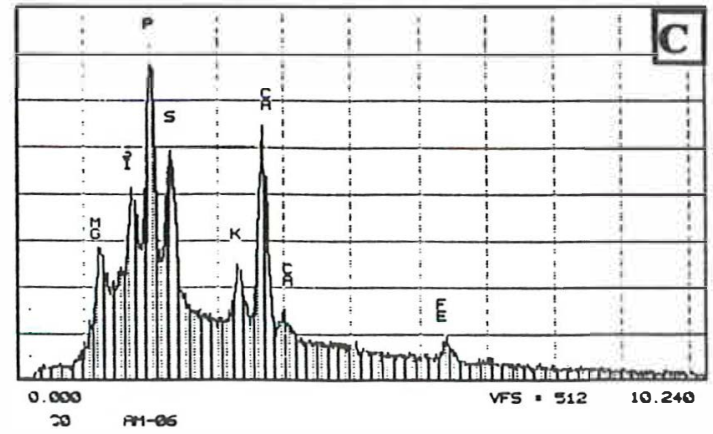

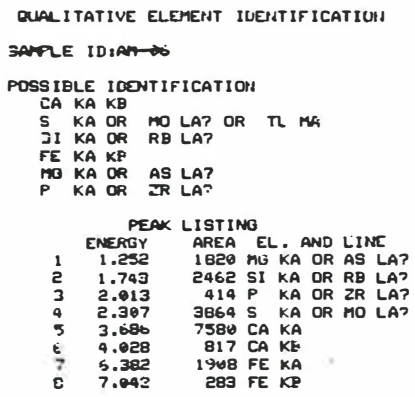

$\pi 1-5 \infty$

Sur eor : 0.000kev : 0

THW 07-JAN-50 25:16

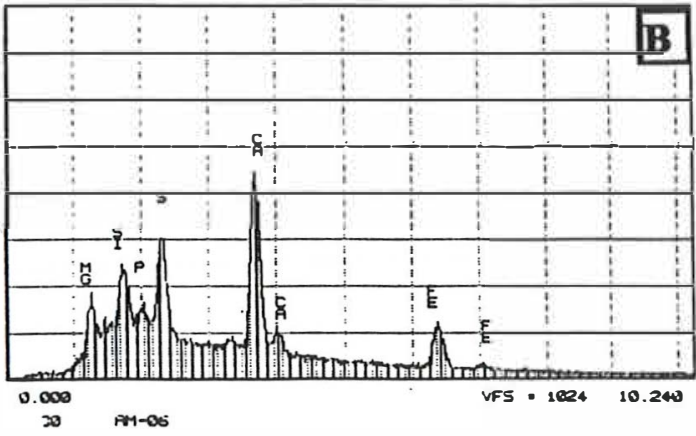

QUAL ITATIVE QEERHT IDESTIFICATIOH

SANPLE IOIAM-US

POSSIBLE IDENTIFICATIOH

3I KA OR SR LA?

AL KA OR BR LA?
VA K.B OR IN LA

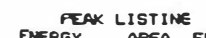

ENERGY AREA EL. AND LINE

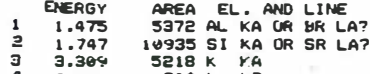

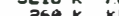

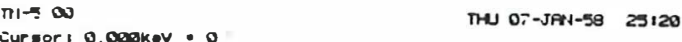

D

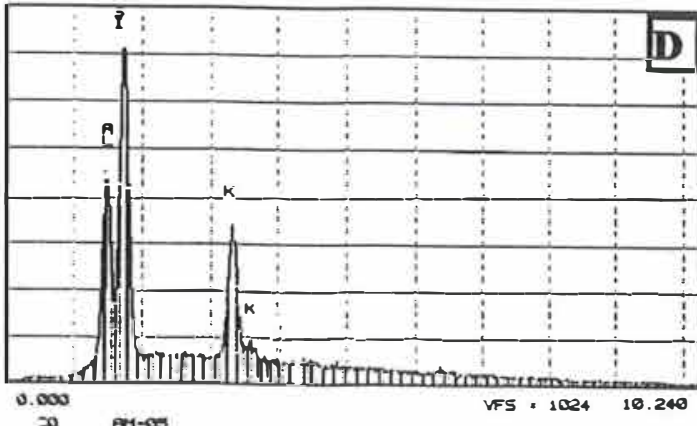

Figura 76 - Picos espectrais referentes às micrografias 1 - A: Crosta ferruginosa na superficie de um folhelho em alteração no horizonte A de Pl (2 anos); B: Agregados orgânicos que se encontram entre as lâminas de esfoliação dos folhelhos; C: Agregado orgânico em decomposição; D: Placas de mica no perfil P2 (15 anos). 

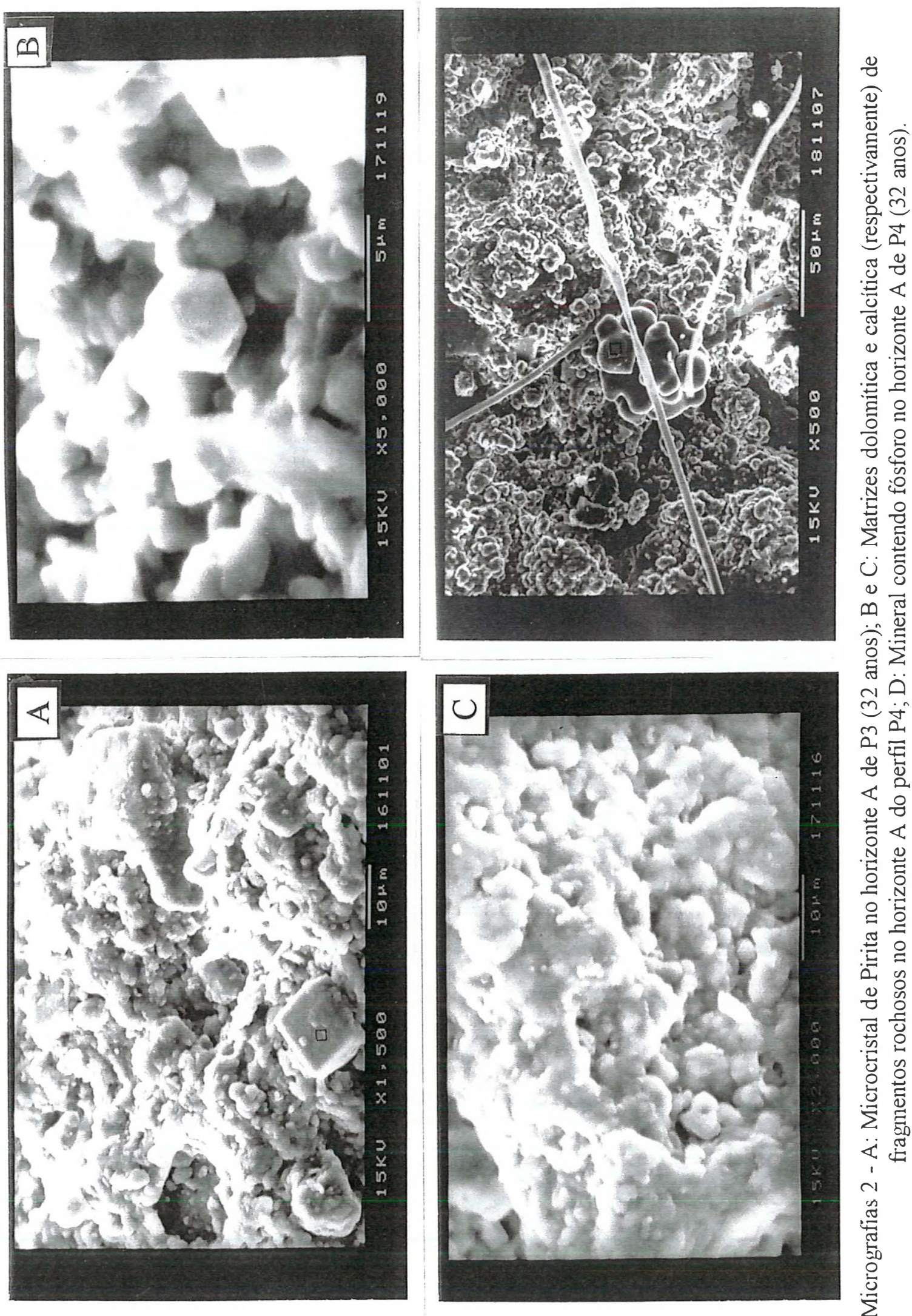

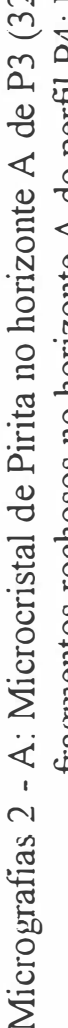


IDEAT-EF:C,

SULL ITATI', EE ELEMENT IDENTIFICATION

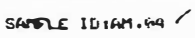

POSSIBLE IDENTIFICATION

TE KA K.

SI KA OR RE LÁ-

MG KGA OR AE LF:

PNERGY LISTING

AREA EL. ATID LINE

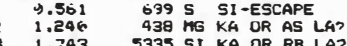

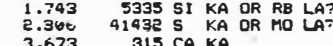

3.673
6.370
7.03

7.37\% 19515 FE KA
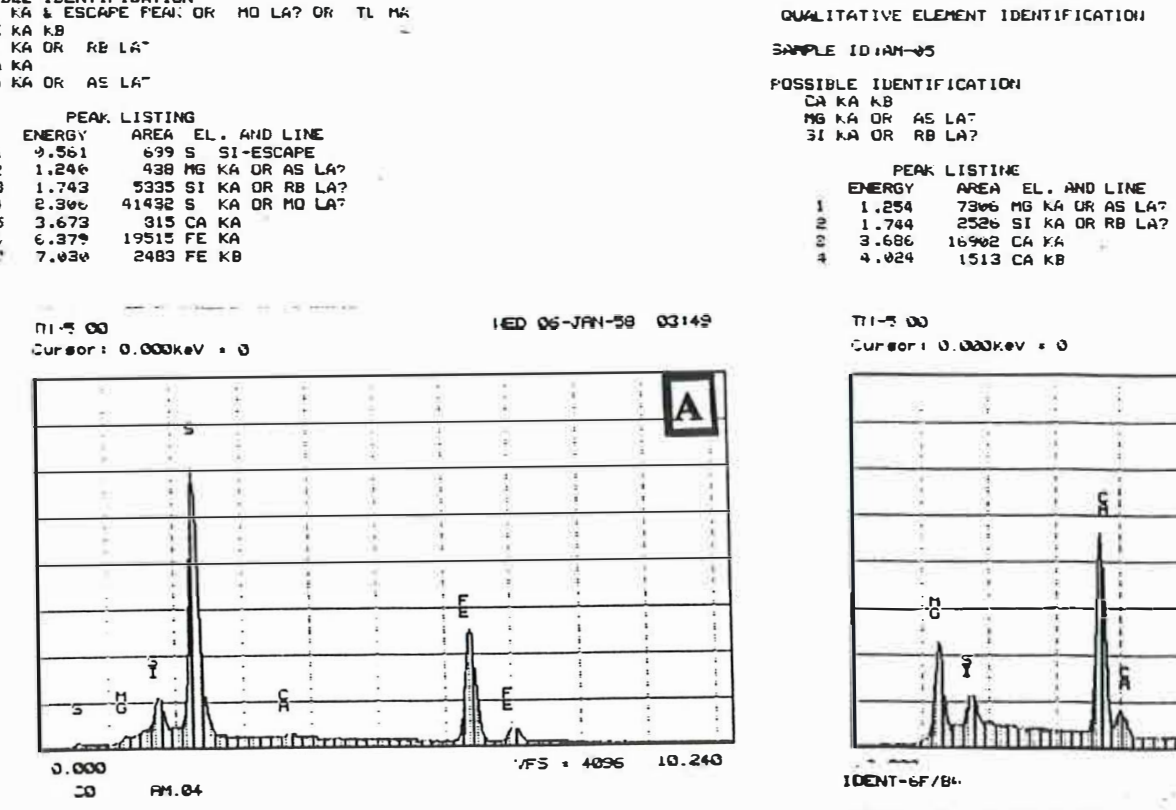

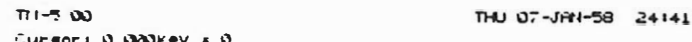

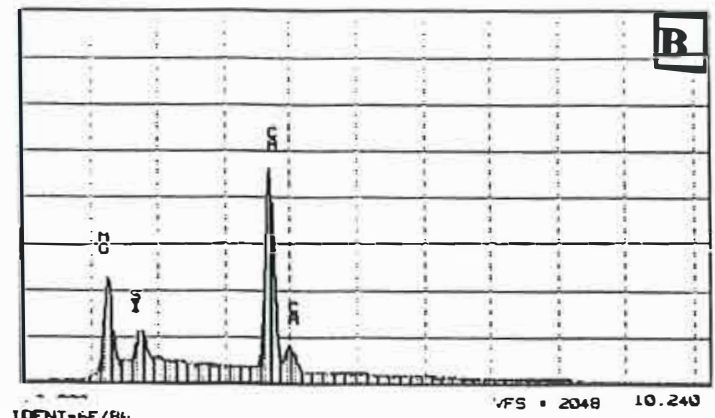

IDENT-GF/EL

FS $2048 \quad 10.240$

CALITATIVE ELERTI IDENTIFICATION

QUHLITITINE ELEMENT IUEMTIFILATLLH

SARPLE IDIANAT

POSSIBLE IDENTIFICATION

$P$ KA OR ZR LAT
K $K A$ OR IN

MB KA OR AS LA?

FOSSIGLE IDEHTIFICATIOH

SA KA KB

MG KA UR AS LA?

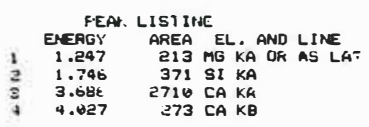

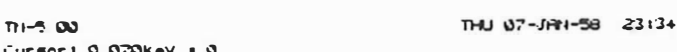

Eursor $10.070 \mathrm{kev}$.

\section{C}

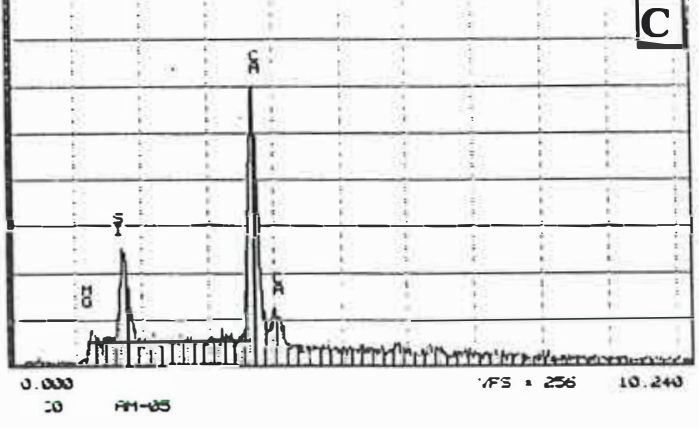

PEAK LISTING

D.

1.355

469 S KA OR PB MA?

3.673 2280 IN LBZ IN LA?

$\pi i s \infty$

Eursor' o.cokkev - 0

THS $07-$ JFN-58 32133

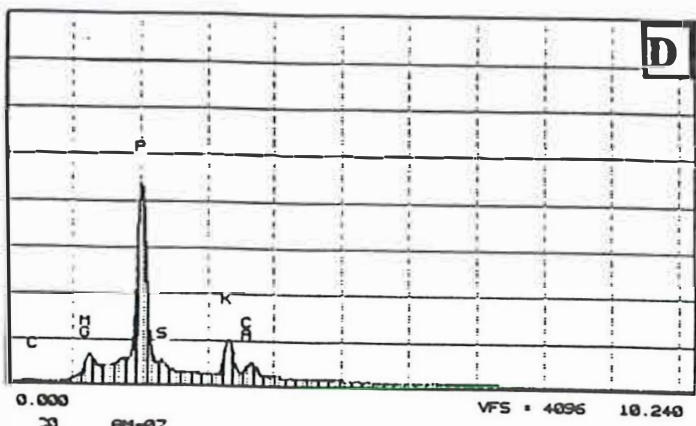

Figura 77 - Picos espectrais referentes às micrografias 2 - A: microcristal de pirita no horizonte A de P3 (32 anos); B: e C matrizes dolomítica e calcítica (respectivamente) de fragmentos rochosos no horizonte A do perfil P4; D mineral amorfo contendo fósforo no horizonte A de P4 (32 anos). 


\section{CONSIDERAÇÕES FINAIS SOBRE OS SOLOS EM FORMAÇÃO SOBRE REJEITOS DE MINERAÇÃO DE CALCÁRIO}

Através deste estudo pode-se constatar que o tempo decorrido foi

suficiente para promover alterações fisicas e químicas nos bancos de rejeitos da mineração do calcário Irati, levando à uma evolução pedogenética destes materiais. Isso é evidenciado pela formação de um horizonte A de estrutura granular fraca no perfil P1 (2 anos de deposição), aberto em um banco formado por fragmentos rochosos de calcário e folhelhos misturados com blocos argilosos. Nos montes constituídos basicamente por fragmentos rochosos, a estruturação não foi evidenciada no perfil P2 (15 anos). Somente nos perfis abertos nos montes de 32 anos (P3, P4 e P5), encontram-se horizontes A com cerca de $3 \mathrm{~cm}$ de espessura com estrutura granular média.

Comparando-se a formação da estrutura em P1, formado pela mistura de materiais rochosos e argilosos com os demais perfis rochosos, onde somente observou-se a formação de estrutura nas áreas de 32 anos, pode-se constatar que a evolução da estrutura é mais acelerada onde os fragmentos rochosos são mesclados à material argiloso.

O horizonte $\mathrm{O}$ com cerca de $3 \mathrm{~cm}$ de espessura, foi observado nas áreas de 15 e 32 anos, sobre cobertura de leucena. Na área de 2 anos de exposição e na área de 32 anos, sobre pastagem, esse horizonte não se apresentou com nitidez.

Os perfis mais recentes apresentaram perda de plasma e acumulação relativa de esqueleto nos primeiros milímetros superficiais, no caso de P1 ( 2 anos), que ainda não possui um horizonte $\mathrm{O}$ típico e na transição dos horizontes $\mathrm{O} / \mathrm{Cl}$, no caso do perfil P2 (15 anos). Ainda no perfil P2, o material fino proveniente da transição $\mathrm{O} / \mathrm{C} 1$ tende a ser depositado nos espaços existentes entre os fragmentos rochosos de $\mathrm{C} 1$. 
As observações da estrutura feitas em lupa binocular e em lâminas delgadas (microscópio ótico) revelam a evolução da porosidade em função do tempo. A porosidade encontrada no horizonte A do perfil P1 (2 anos) é basicamente fissural formada pela contração das argilas, fragmentação de rochas e pela perda de plasma. Estas fissuras aliadas à canais radiculares e galerias, formam uma rede de poros contínuos neste horizonte.

A porosidade encontrada na transição dos horizontes $\mathrm{O} / \mathrm{C} 1$ do perfil $\mathrm{P} 2$ (aberto em um banco rochosos, com 15 anos deposição) é representada por vazios provenientes do arranjo aleatório dos fragmentos rochosos e perda de plasma. Neste perfil, o material fino tende a se deslocar do horizonte da transição dos horizontes $\mathrm{O} / \mathrm{Cl}$ e se acumular em $\mathrm{Cl}$ nos espaços existentes entre os fragmentos rochosos.

$\mathrm{Na}$ área de 32 anos também observa-se uma porosidade formada por fissuras na matriz plasmática, mas é abundante o número de bioporos contínuos que se interligam entre si.

A análise granulométrica indica maiores concentrações da fração TFSA nos horizontes superficiais e próximo à superfície de todos os perfis. A fragmentação de rochas próximo à superficie foi retratada nas microfotografias de lâminas delgadas dos horizontes superficiais dos perfis P1 (2 anos) e P2 (15 anos). As observações de lâminas delgadas, juntamente com os dados das análises granulométricas evidenciam a ocorrência do intemperismo fisico, o qual provoca rápida fragmentação das rochas próximo à superficie destes solos.

O intemperismo químico é evidenciado primeiramente pelas observações morfológicas em campo, onde se constata a alteração da cor de fragmentos rochosos, denotando principalmente a oxidação do ferro na superficie dos folhelhos. Além disso, a presença de precipitados de gipso e sulfato de ferro, que aparecem na forma de eflorescências nas superficie de alterações das rochas e nas paredes expostas do perfil e, as análises químicas que revelam a ocorrência de lixiviação de $\mathrm{Ca}, \mathrm{Na}, \mathrm{e} \mathrm{S}-\mathrm{SO}_{4} \mathrm{em}$ todos os perfis (salvo $\mathrm{Ca}$ em $\mathrm{P} 1$, com 2 anos), reforçam as evidências da atuação do intemperismo químico. 
As análise químicas também revelam que ocorrem maiores concentrações de $\mathrm{K}$, carbono e nitrogênio na superficie destes solos em formação. A maior concentração de $\mathrm{K}$ pode ocorrer devido à intemperização de minerais potássicos próximo à superficie destes solos recentes de mina, bem como pode ser devido à fito ciclagem deste nutriente. As maiores concentrações de $\mathrm{N}$ e carbono orgânico superficiais é uma decorrência da acumulação biológica promovida pela vegetação de cobertura (leucena e gramíneas/leucena).

Os valores de $\mathrm{pH}$ em $\mathrm{H}_{2} \mathrm{O}$ podem ser classificados como ligeiramente ácidos a ligeiramente alcalinos e os teores de fósforo são frequentemente elevados nestes solos de mina.

O tempo de exposição dos rejeitos influencia a evolução destes solos recentes de mina, uma vez que a fragmentação das rochas na superficie destes montes, a estruturação, a lixiviação de $\mathrm{Ca}$, $\mathrm{Na}$ e S-SO4 e o acúmulo de $\mathrm{K}$, carbono e nitrogênio total e os teores de P são incrementados com a idade dos montes.

Os índices de intemperismo $\mathrm{Ki}$ e $\mathrm{Kr}$ não apontaram nenhuma evidência de evolução, talvez devido à recente exposição do material, no caso de Kr. Nestes solos de mina, o Ki não pode ser utilizado como índice de intemperismo por apresentar-se muito variável e elevado devido, em parte, à grande variabilidade dos fragmentos pertencentes à fração TFSA, como também às grandes quantidades de silício em relação aos conteúdos de $\mathrm{Al}$, inerentes ao próprio material de origem.

A mineralogia destes solos reflete a do material de origem, principalmente a do folhelho carbonoso. Não se percebe grandes alterações mineralógicas, salvo que na superficie das áreas mais velhas nota-se a presença de argilo-mineral 1:1, não observado no material de origem.

Os solos de mina estudados apresentam na fração areia fragmentos de folhelhos, calcários e sílex. $\mathrm{Na}$ areia muito fina observa-se quartzo e sílica amorfa ou mal cristalizada, indícios de feldspatos e de mica. Quartzo, plagioclásios e indícios de ortoclásio estão presentes na fração silte e esmectita, ilita e argilo-mineral 1:1 na fração argila. 


\section{CONCLUSÕES}

1- O tempo decorrido causou alterações na granulometria e na química dos rejeitos, mas não foi suficiente para causar grandes alterações mineralógicas.

2- Ocorre decréscimo da fração $>2 \mathrm{~mm}$ e aumento da fração TFSA e uma tendência de aumento da fração silte e argila próximo à superficie destes solos de mina.

3- As principais alterações químicas ocorridas são a lixiviação de $\mathrm{Na}, \mathrm{Ca}$ e $\mathrm{S}^{-\mathrm{SO}_{4}} \mathrm{e}$ o acúmulo de $\mathrm{K}$, carbono orgânico e nitrogênio próximo à superficie.

4- No monte formado por fragmentos rochosos misturados com blocos argilosos, o período de 2 anos de exposição do rejeito foi suficiente para o desenvolvimento de um horizonte A com estrutura fraca pequena a muito pequena granular de $3 \mathrm{~cm}$ de espessura,

5- Nos montes constituídos basicamente por fragmentos rochosos (calcário com sílex e folhelhos carbonosos e pirobetuminosos), o horizonte A não foi evidenciado no monte de 15 anos. Entretanto, esse período foi suficiente para a formação e manutenção de um horizonte $\mathrm{O}$ com cerca de $3 \mathrm{~cm}$ de espessura. Somente no monte com 32 anos evidenciou-se um horizontes A com $3 \mathrm{~cm}$ de espessura e com estrutura moderada muito pequena a pequena granular ou moderada muito pequena em blocos.

7- Nos perfis rochosos, o arranjo aleatório das diferentes rochas facilita a intemperização do material pois permite a penetração de ar e a infiltração da água no perfil. Isso parece favorecer esfoliação dos folhelhos, favorecendo a oxidação evidenciada pela coloração da superficie de suas placas que podem chegar a cores $10 \mathrm{R}$.

8- Rejeitos que possuem material argiloso misturado aos fragmentos de rocha possuem evolução estrutural mais acelerada que os rejeitos constituídos somente por fragmentos rochosos. 


\section{REFERÊNCIAS BIBLIOGRÁFICAS}

ABREU, C. A. de; ABREU M. F. de. A extração com DTPA: determinação de cobre, ferro, manganês e zinco em solos. protocolo anaítico IAC. Capinas, 1996, 9 p.

ABREU, C. A. de; ABREU M. F. de. Análise de boro em solos usando a solução de cloreto de bário. protocolo anaítico IAC. Capinas, 1996, 8 p.

ALEXANDER, M. J. Soil characteristics and the factor influencing their developmente on mine spoil of the Jos Plateau. Report, Jos Plateau Environmental Development Programme. no 11, 1986. 167 p. /Resumo em CAB Abstracts on CD-ROM, 1987-89/

ALMEIDA, R. B. Caracterização dos solos de rejeitos da mineração do calcário Partezani na região de Rio Claro. SP. Rio Claro, 1983. 29 p. Monografia (Graduação). Instituto de Biociências - Universidade Estadual Paulista "Julio de Mesquita Filho".

ANDERSON, D. W. Early stages of soil formation on glacial till mine spoils in a semiarid climate. Geoderma, v. 19, p. 11-19, 1977.

BARROW N. J. Modelling the effects of $\mathrm{pH}$ on phosphate sorption by soils. Journal of Soil Science, v. 35, p. 283-297, 1984. 
BELL, J.C.; CUNNIGHAM, R. J.; ANTHONY, C. T. Morpholgical characteristcs of reconstructed prime farmland soil in western Pennsylvania. Journal of Environmental Quality, v. 23, p. 515-520, 1994.

CALERO-MARINO, M. Mineralogia e gênese de solos originados de rochas da Formação Irati: região de Piracicaba - SP. Piracicaba, 1999. 207 p. Tese (Doutorado). Escola Superior de Agricultura "Luiz de Queiroz", Universidade de São Paulo.

CAMARGO, O. A.; MONIZ, A. C.; JORGE, J. A.; VALARES, J. M. A. S. Métodos de análise química, mineralógica e física de solos do Instituto Agronômico de Campinas. Campinas: LAC, 94 p. 1986 (Boletim técnico 106).

CARUCCIO, F.T.; HOSSNER, L. R.; GEIDEL, G.; HOSSNER, L. R. Pyritic materials: acid drainage, soil acidity, and liming. Reclamation of Surface Mined Lands. v 1, p. 159-189, 1988. /Resumo em CAB Abstracts on CD-ROM, 1987-1989/

CASTRO, S. S. Impregnação de amostras de solo para confeç̧ão de lâminas delgadas. Boletim Informativo/S.B.C.S. Campinas. 10:44. 1985.

CHICHESTER, F.W.; HAUSER, V. L. Change in chemical properties of constructed minesoils developing under forage grass management. Soil Science Society of America Journal, v. 55, p 451-459, 1991.

CHO, C. M.; CALDWELL, A. C. Forms of phosphorus and fixation in soils. Soil Science Society Proceedings, v, p. 458-460. 1959. 
CIOLKOSZ, E. J.; CRONCE, R. C.; CUNNINGHAM, R. L.; PETERSEN, G. W. Characteristics, genesis, and classification of pennsylvania minesols. Soil Science, v. 139, p. 232-238, 1985.

COILE, T. S. Moisture content of small stone in soil. Soil Science, v. 75, p. 203-207, 1952.

COLE, C. V., OLSEN, S. R., SCOTT, C. O. The nature of phosphate sorption by calcium carbonate. Soil Science Society Proceedings, v 90, p. 352-356, 1953.

CROCKER, R. L., MAJOR, J. Soil development in relation to vegetation and surface age at glacier bay, Alaska. Journal of Ecology, v. 43, p 427-448, 1955.

DAHIMAN, R. C.; KUCERA, C. L. Root productivity and turnover in native prairie. Ecology, v. 46, p. 84-89, 1965.

DANCER, W. S. HANDLEY, J. F. BRADSHAW, A. D. Nitrogen accumulation in Kaolin mining wastes in corwall. I. Natural communities. Plant and Soil, v. 48, p. 153-167, 1977 a.

DANCER, W. S. HANDLEY, J. F. BRADSHAW, A. D. Nitrogen accumulation in Kaolin mining wastes in corwall. I. Forage legumes. Plant and Soil, v. 48, p. 303314,1977 b.

DOOLITTLE, J. J.; HOSSNER, L. R.; WILDING, L. P. Simulated aerobic pedogenesis in piritic overburden with a positive acid-base account. Soil Science Society of America Journal, v. 57, p. 1330-1336, 1993. 
DOWN, C. G. Soil development on colliery waste tips in relation to age. I. Introdution and physical factors. Journal of Applied Ecology, v. 12, p. 613-622, 1975 a.

DOWN, C. G. Soil development on colliery waste tips in relation to age. II chemical factors. Journal of Applied Ecology, v. 12, p. 623-635, 1975 b.

ELLIS, R.; TROUG, E. Phosphate fixation by montmorillonite. Soil Science Society Proceedings, v. 19 , p. 451-454, 1955.

EMBRAPA. Manual de métodos de análises de solo. Emprapa, 212 p. 1997.

FITTER, A. H., BRADSHAW, A. D. Response of Lolium perenne and Agrotis tenuis to phosphate and other netritional factors in reclamation of colliery shale. Journal of Applied Ecology, v 11, p. 597-600, 1973.

FREEMAN, J. S.; ROWELL, D. L. The adsorption and precipitation of phosphate onto calcite. Journal of Soil Science, v. 32, p. 75-84, 1981.

GRIFFIN, G. M. Interatin of x- ray diffraction data. In: CAVER, ROBERT E. (Ed). Procedures in sedimentary petrology. New York: Wiley-interscince, 1971. cap 24, p. 541-569: Interatin of $x$ - ray diffraction data.

HAERING, K. C.; DANIELS, W. L.; ROBERTS, J. A. Changes in mine soil properties resulting from overburden weathering. Journal fo Environmental Quality, v. 22, p. 194-200, 1993. 
HANSON, C. T.; BLEVINS, R. L. Soil water in coarse fragments. Soil Science Society of America Journal, v. 43, p. 819 - 820. 1979.

HOLE, F. D. A classification of pedoturbation and some other processes and factores of soil formation in relation to isotropism and anisotropism. Soil Science, v. 91, p. 375-377, 1961.

HOLFORD, I. C. R.; MATTINGLY, G. E. C. Phosphate sorption by Jurassic Ooilitic limestone. Geoderma, v. 13, p. 257-264, 1975.

HOLMGREN, G. G. S. A rapid citrate-didionite extractable iron procedure. Soil Science of America Proceedings, v. 31, p. 210-211, 1967.

HOWARD, J. L.; AMOS, D. F.; DANIELS, W. L. Phosphorus and potassium relationships in Southwestern Virginia coal-mine spoils. Journal of Environment Quality, v. 17, p. 695-700, 1988.

HOWER, J. M.; BARNHISEL; R. I. HOPKINS T. C. Physical and chemical properties of potential topsoil substitutes in Kentucky oil shale mining reclamation. Journal of Environmental Quality, v. 21, p. 502-508, 1992.

HOWER, J; ESLINGER, W. V.; HOWER, M.; PERRY, E. A. Mechanism of burial metamorphism of argillaceous sediments: I. Mineralogical and chemical evidence. Geologic Society of America Bulletin, v. 87, p. 725-737, 1976.

HSU, P. H.; JACKSON, M. L. Inorganic phosphate transformations by chemical weathering in soils as influenced by pH. Soil Science, v. 90, p. 16-24, 1960. 
JACKSON, M. L. Soil chemical analysis. Advance Course. $2^{\text {nd }}$ ed. Madson, Wisconsim: University of Wisconsin - Departament of Soil Science, 1969. 894p.

JEFFERIES, R. A.; BRADSHAW, A. D., PUTWAIN, P. D.; Growth, nitrogen accumulation and nitrogen transfer by legume species established on mine spoil. Journal of Applied Ecology, v. 18, p. 945-956, 1981.

JOHNSON, F. L.; GIBSON, D.J.; RISSER, P.G. Revegetation of unreclaimed coal strip-mines in Oklahoma. I. Vegtation structure and soil properties. Journal of Applied Ecology, v. 19, p. 453-463, 1982.

KÄMPF, N., SCHNEIDER, D., GIASSON, E. Propridades, pedogênese e classificação de solos construídos em áreas de mineração na Bacia Carnonífera do Baixo Jacuí (RS). Revista Brasileira de Ciencias do Solo, v. 21, p. 79-88, 1997.

KRECHETOVA, Y. V. Comparative description of composition and properties of humic acids of oil shales ans soils. Eurasian Soil Science, v. 28: 5, p. 48-64, 1996.

LEMOS, R. C.; SANTOS, R. D. Manual de descrição e coleta de solo no campo. Campinas, Sociedade brasileira de ciência do solo, 1996. 84 p.

LOPEZ-HERANDEZ, D.; BURNHAN, C. P. The effect of $\mathrm{pH}$ on phosphate adsorption in soils. Journal of Soil Science, v. 25, p. 207-216, 1974.

MALAVOlTA, E.; VITTI, G. C.; DE OLIVEIRA, S. A. Avaliação do estado nutricional das plantas, pricípio e aplicações ( $2^{\mathrm{a}}$ edição). Piracicaba: POTAFOS, 1997. p. 231-253. 
MANDEL, R. D.; SORENSON, C. J. The role of the western harvester ant (Pogonomyrmex occidentalis) in soil formation. Soils Science Society of America Journal, v. 46, p. 785-788, 1982.

McGINNIES, W. J.; CROFTS, K. A. Effects of $\mathrm{N}$ and $\mathrm{P}$ fertilizer placement on establishement of seeded species on redistributed mine topsoil. Journal of Range Management, v.39, p. 118-121, 1986.

McSWEENEY, K., JANSEN, L. J. Soil estructure and associated rooting behavor in minesoils. Soil Science Society of America Journal, v. 48, p. 607-612, 1984.

MELA-MELA, P. Tratado de edafologia y sus distintas aplicaciones. Zaragoza: Agrociencias, 1963, p. 81-169. El complejo inorganico.

MELLO, F. A. F.; SOBRINHO, M. O. C. B.; ARZOLLA, S. SILVEIRA, R. I.; NETTO, A. C.; KIHEL, J. C. Fertilidade do Solo.. São Paulo: Nobel, 1989. 400 p.

MENEGON, V. A. Aspectos gerais sobre as minerações de calcário da Formação Irati e caracterização geotécnica do rejeito na região de Rio Claro e Piracicaba (SP). Rio Claro, 1990. 66 p. Dissertação (Mestrado). Univercidade Estadual Paulista "Julho de Mesquita Filho".

MERMUT, A. R. CURTIN, D. ROSTAD, H. P. W. Micromorfological and submicromorfological features related to pyrite oxidation in an inlad marine shale fron East Central Saskatchewan. Soil Science Society of America Journal, v. 49, p. 261-256, 1985. 
MEURER, E. J., KÄMPF, N., ANGHINONI, I. Fontes potenciais de potássio em alguns solos do Rio Grande do Sul. Revista Brasileira de Ciência do Solo, v. 20, p. 4147, 1996.

MONIZ, A. C., OLIVEIRA, J. O. CURI, N. Mineralogia da fração argila de rochas sedimentares e de solos da Folha de Piracicaba, SP. Revista Brasileira de Ciência do Solo, v. 19, p. 375-385, 1995.

MONTERROSO-MATINEZ, M. C. Caracterizacion de los procesos edafogeoquimicos en una escombrera de esteriles de lignito en proceso de restauracion ambiental. Santiago de Compostela, 1995. 533 p. Tese (Doutorado). Universidad de Santiago de Compostela.

PARAGUASSÚ, A. B.;GANDOLFI, N.; RODRIGUES, J. E.; PORTIOLLO, E. Z. F.; ZUQUETTE, L. V.; CAMPOS, J. O.; MENEGON, V. A. Ensaios de caracterização tecnológica do rejeito da exploração de calcário da Formação Irati (P), na região de Rio Claro - SP. In: VII CONCRESSO LATINO-AMERICANO DE GEOLOGIA, Belém, 1983. Anais. Belém, 1983. p. 476-485.

PARFITT, R. L.; ATKINSON, R. J.; SMART, R. S. The mechanism of phosphate fixation by iron oxides. Soil Science Society of America Proceedings, v. 39, p. 837-841, 1975.

PEDERSEN, T. A.; ROGOWSKI, A. S.; PENNOCK Jr., R. Physical characteristics of some minesoils. Soil Science Society of America Journal, v. 44, p. 321-328, 1980.

POWER, J. F.; BOND, J. J.; SANDOVAL, F. M., WILLIS, W. O. Nitrification in Paleocene Shale. Sciesnce, v. 183, p. 1077-1079, 1974. 
PULFORD, I. D.; DUNCAN, H. The influence of pyrite oxidation products on the adsorption of phosphate by coal-mine waste. Journal of Soil Science, v. 26, p. 74$80,1975$.

QUINTAS-MOSTERIRO, I. Q. Caracterizacion y posibilidades de recuperacion de antrosoles de cateras y minas de Galicia. Santiago de compostela, 1997. 332p. Tese (Doutorado). Universidad de Santiago de Compostela.

REEDER, J. D.; BERG, W. A. Nitrogen mineralization nad nitrification in a Cretaceous shale and coal mine spoil. Soil Science Society America Journal, v. 41, p. 922-927, 1977.

RITSEMA, C. J.; GROENENBERG, J. E. Pyrite oxidation, carbonate weathering, and gypsum formation in a drained potential acid sulfate soil. Soil Science Society America Journal, v. 57, p. 968-976, 1993.

ROBERSON. H. E., LAHANN, R. W. Smectite to ilite conversion rates: Effects of solution chemistry. Clays and Clay Minerals, v. 29, p. 129-135, 1981.

ROBERTS, J. A. DANIELS, W. L.; BELL, J. C.; BURGER, J. A. Early stages of mine soil genesis in a southwest Virginia spoil lithosequence. Soil Science Society of America journal, v. 52, p. 716-723, 1988 a.

ROBERTS, J. A. DANIELS, W. L.; BELL, J. C.; BURGER, J. A. Early stages of mine soil genesis as affected by topsoiling and organic amendments. Soil Science Society of America Journal, v. 52, p. 730-738; 1988 b. 
ROBERTS, J. A. DANIELS, W. L.; BELL, J. C.; MARTENS, D. C. Tall feacue production and Nutrient Status on southwest Virginia soils. Journal of Environmental Quality, v. 17, p. 55-62, 1988 c.

ROBERTS, R. D., MARRS, R. H., SKEFFINGTON, R. A., BRADSHAW, A. D. Ecosystem development in naturally colonized shina clay wasts. I. Vegetation changes and accumulation of biomass and nutrients. Journal of Ecology, v. 69, p. 153-161, 1981.

SCHAFER, W. M.; NIELSEN, G. A; NETTLETON, W. D. Minesoil genesis and morfology in a spoil chronosequence in Montada. Soil Science Society of America Journal, v. 44, p. 802 - 807, 1980.

SCHORI, A.; HASTIE, W. J.; McQUEEN, D. K.; MENNING, G. V.; WENZEL, E. C. Coal mine soil and overburden surveys and reclamation planing. Proceedings of the Conference 'Reclamation, a Global Perspective'. v. 2, p. 579-588, 1989. /Resumo em CAB Abstracts on CD-ROM, 1990-91/

SKEFFINGTON, R. A., BRADSHAW, A. D. Nitrogen accumulation in kaolin wastes in cornwall. Plant and Soil, v. 62, p. 439-451, 1981.

SOAVE, R. C. F. Aspectos de mineração de calcário no município de Rio Claro, Estado de São Paulo: Avaliação da recuperação natural do solo e da vegetação. Rio Claro, 1996. 237 p. Tese (Doutorado). Universidade Estadual Paulista "Julio de Mesquita Filho".

STEVENSON, F. J. On the presence of fixed ammonium in rocks. Science, v. 130, p. 221-222, 1959. 
TELLES, E. C. C. Formação de depreções sobre materiais da Formação Irati, em Piracicaba (SP). Piracicaba, 1997, 88 p. Dissertação (Mestrado). Escola superior de agricultura "Luiz de Queiroz", Universidade de São Paulo.

THOMAS, D. \& JANSEN, I. Soil development in coal mine spoil. Journal of Soil and Water Conservation, v. 33, p. 439-442, 1985.

TRASAR-CEPEDA, M. C.; DE BLAS, E.; GARCIA-RODEJA, I.; LEIRÓS, M. C., GIL-SOTERES, F. Modification of the phosphorus cycle with development of mine soils. Land Degradation and Rehabilitation, v. 4, p. 131-142, 1993.

VARELA, C. VÁZQUEZ, C. GONZÁLEZ-SANGREGORIO M. V., LEIRÓS, M. C.. GIL- SOTRESS, F. Chemical and physical properties os opencast lignite menesoils. Soil Science, v. 156, p. 193-203, 1993.

VIEIRA, L. S. Manual de ciências do solo: com ênfase em solos tropicais. São Paulo: Ceres, 1988, capítulo 12, p. 253-299. Argila e mineral de argila.

VITTI, G. C. Avaliação e interpretação do enxofre no solo e na planta. Jaboticabal: FCAV-Universidade Estadual Paulista "Julio de Mesquita Filho". 1989. 37 p.

WANG, M. K.; TZOU, Y. M. Phosphate sorption by calcite, and iron rich calcareous soil. Geoderma, v. 65, p. 249-261, 1995.

WILSON, H. A. Effect of vegetation upon aggregation in strip mine spoils. Soil Science Society Proceedings, v. 21, p. 637-640, 1957. 
WOOD, C. W. PETTRY, D. E. Initial pedogenic progression in a disturbed farmland soil. Soil Science, v. 147, p. 196-207, 1989.

WOODMANSEE, R. G. Additions and losses of nitrogen in grasland ecosystems. Bioscience, v. 28, p. 448-453, 1978. 
Anexo A1 - Descrição morfológica dos perfis dos solos em formação sobre rejeitos de mineração de calcário 


\section{A1.1 Perfil P 1 - Aberto em rejeitos constituídos de uma mescla de fragmentos rochosos de calcário, síex, blocos de argilito e solo com 2 anos de repouso $e$ sobre vegetação de transição gramíneas/leucena.}

\section{A1.1.1 Descrição morfológica de P1}

L - 3 - $0 \mathrm{~cm}$ - Liteira formada pela deposição de restos vegetais das gramíneas que já estavam mortas em decorrência do abafamento e, menos freqüente, da leucena.

A - 0 - $3 \mathrm{~cm}$ : - cinzento muito escuro (2,5Y3/0 úmido) a bruno-acinzentado muito escuro (2,5Y3/2, úmido); muito argiloso com cascalhos; fraca pequena a muito pequena e pequena granular e raramente moderada blocos pequenos e angulares (remanescente de antigos horizontes de solos); ligeiramente duro, muito friável, plástico e ligeiramente pegajoso; poros pequenos e arredondados e médios; raízes finas; transição abrupta.

C1- 3 - 30 cm: - bruno-amarelado-escuro (10YR4/4, úmido), bruno-oliváceo (2,5Y4/4, úmido) e bruno-oliváceo-claro (2,5Y5/4, úmido) (matriz). Comuns blocos de argilito cinzento-avermelhado (10R5/1, úmido) e argilitos cinzento (7,5YR5/0, úmido) com mosqueado abundante, médio, distinto, amarelo avermelhado (7,5YR7/8, úmido) ao lado de outros blocos cinzento (5YR6/1, úmido) com mosqueado abundante, médio, distinto vermelho (10R4/8, úmido); argila muito cascalhenta com calhaus e alguns matacões, maciça com aspecto compactado, alguns volumes com estruturação forte a moderada pequena em blocos angulares, duro a muito duro, firme, plástico e ligeiramente pegajoso. Poros comuns, arredondados de tamanho pequeno e médio que diminuiam de freqüência com a profundidade; raizes comuns nos primeiros dez centímetros da trincheira, diminuindo a freqüência a 
medida que avançava a profundidade em $\mathrm{Cl}$, onde penetram ocupando canais pequenos e fissuras existentes entre os fragmentos rochosos e os blocos de argilito ou na interface rocha/matriz adensada. Transição ondulada e clara (espessura: 9 a $29 \mathrm{~cm}$ ).

C2 - 30 - $80 \mathrm{~cm}$-. bruno-escuro (10YR4/3, úmido), bruno-oliváceo-claro (2,5Y5/4), úmido) e bruno-oliváceo (2,5Y4/4, úmido); argila muito cascalhenta com calhaus e matacões, vários volumes com estruturação forte em blocos angulares muito pequenos e pequenos a médios; duro, friável, plástico e pegajosa. Muitos poros pequenos. Raízes finas e médias abundantes e bem distribuídas; (50 - $70 \mathrm{~cm}$ de espessura)

\section{A1.2 - Perfil P 2 - Aberto em rejeitos constituídos de uma mescla de fragmentos rochosos de calcário, silex e argilito com 15 anos de repouso e sobre vegetação de leucena.}

\section{A1.2.1 Descrição morfológica de $\mathbf{P 1}$}

L - 7 a $3 \mathrm{~cm}$ : - Camada de liteira formada por restos vegetais ainda identificáveis provenientes da leucena.

O - 3 a 0 cm: -. bruno-acinzentado muito escuro (10YR $3 / 2$, úmido) e bruno muito escuro (10YR2/2, úmido) (cores da matriz); argilo-arenosa muito cascalhenta; fraca, granular muito pequena; solto, muito friável não plástico e não pegajoso. Poros pequenos e abundantes. Raízes finas freqüentes se distribuem neste horizonte e raízes médias se desenvolvem horizontalmente na transição $\mathrm{O} / \mathrm{Cl}$. Transição abrupta.

C1 - 0 a $20 \mathrm{~cm}$ : bruno-acinzentado muito escuro (2,5Y3/2, matriz úmida). Areno-argilosa muito cascalhenta e com calhaus; sem estrutura, rompendo-se em fragmentos 
individuais; solto, muito friável, não plástico e não pegajoso. Porosidade fissural e vãos decorrentes do empilhamento dos fragmentos rochosos. Raízes pequenas, muito abundantes, que formam uma rede e ocupam os espaços entre os fragmentos de rocha conferindo estabilidade ao desmantelamento desse material. Há pouca eflorescência de gipso, prevalecendo a de cor amarelada de aparência pulverulenta que se forma entre as placas de esfoliação dos folhelhos. Transição ondulada clara.

C2 - 20 a $100 \mathrm{~cm}$ : bruno-acinzentado escuro (2,5Y4/2, úmido) e buno-acinzentado (2,5Y5/2, úmido); arenosa muito cascalhenta com calhaus e matacões; sem estrutura e sem coerência, rompendo-se em fragmentos individuais; solto, muito friável, não plástico e não pegajoso; porosidade fissural e vãos existentes devido ao empilhamento aleatório dos fragmentos de rocha. Abundância de eflorescência de precipitados cristalinos aciculares, provavelmente gipso, que tendem em aumentar com a profundidade. Raízes menos abundantes que em $\mathrm{Cl}$, porém ainda muito freqüentes, predominando as raízes médias sobre as finas e grossas; as raízes médias e grossas podem demonstrar-se tortuosas devido a impedimento físico oferecido pelos fragmentos rochosos maciços. 


\section{A1.3 Perfil P 3 - Aberto em rejeitos constituídos de uma mescla de fragmentos rochosos de calcário, sílex, e folhelhos com 32 anos de repouso e sobre cobertura de leucena.}

\section{A1.3.1 Descrição morfológica de P3}

L - 6 - 3 cm: - Liteira formada por folhas, hastes, galhos, sementes e cascas de vagens da leucena que podiam ainda ser identificados. Hifas se desenvolviam na liteira, muitas vezes formando uma teia chegando a unir fracamente o material vegetal.

O - 3 - 0 cm: - preto 10YR2/1; argilo-arenosa e cascalhenta; fraca, granular muito pequena; solto, muito friável; não plástico e não pegajoso; comuns poros pequenos a muito pequenos. Raras raízes finas e abundantes hifas brancas. Transição abrupta.

A - 0 - $3 \mathrm{~cm}$ : - bruno-escuro 7,5YR3/4 e amarelo-avermelhado 5YR4/6. Cores mais escuras eram menos freqüentes: cinzento-avermelhado-escuro 5YR4/2 brunoavermelhado-escuro 5YR3/2 (cores úmidas mais representantes em campo); argila cascalhenta; moderada, pequena a muito pequena granular, ou pequena em blocos (menos frequente); ligeiramente duro, friável, plástico e pegajoso. Apresentava poros pequenos a médios e comuns raízes finas. Transição abrupta.

$\mathrm{Cl}$ - 3 - $20 \mathrm{~cm}$ : -. preto 2,5Y2/0 a cinzento muito escuro 2,5Y3/0 (matriz); bruno muito escuro 2,5Y3/2; bruno acinzentado escuro 2,5Y4/2 e bruno-oliváceo 2,5Y4/4 (fragmentos de folhelho); argilo-arenosa muito cascalhenta, com calhaus e matacões; sem estrutura, rompendo-se em fragmentos individuais; ligeiramente duro; friável, não plástico e não pegajoso. Poros pequenos e fissuras. Raízes finas abundantes. Transição clara. 
C2 - 20 a $80 \mathrm{~cm}$ : - vermelho-escuro-acinzentado 10R3/2 e bruno-oliváceo 2,5Y4/4 (folhelho), bruno-acinzentado muito escuro 10YR3/2 e 2,5Y3/1 (úmido, matriz); areno-argilosa muito cascalhenta, com calhaus e matacões; sem estrutura, rompendo-se em fragmentos individuais; ligeiramente duro; friável, não plástico e não pegajoso. Porosidade fissural e vãos deixados em conseqüência do arranjo aleatório dos fragmentos. Raízes médias e tortuosas. Esta camada apresentava eflorescência em sua superficie constituída de sulfato de cálcio. Transição gradativa.

C3 - 80 - $120 \mathrm{~cm}$ - bruno acinzentado escuro 10YR3/3 bruno-oliváceo 2,5Y4/4 e brunoacinzentado muito escuro 2,5Y3/2(úmido, matriz); vermelho-escuro 10R3/6 e bruno forte 7,5YR4/6; amarelo-claro-acinzentado 2,5Y8/4 a amarelo 5Y8/6 (folhelho em diversos estágios de alteração); arenosa e muito cascalhenta com calhaus e matacões de calcário + silex e matacões de folhelhos; sem estrutura, rompendo-se em fragmentos individuais; ligeiramente duro, friável, não plástico e não pegajoso. Porosidade fissural e vãos deixados em conseqüência do arranjamento aleatório dos fragmentos. Comuns raízes médias e finas. Eflorescência abundante. 


\section{A1.4 Perfil P 4 - Aberto em rejeitos constituídos de uma mescla de fragmentos rochosos de calcário, sílex, e folhelhos com 32 anos de repouso e sobre cobertura de leucena.}

\section{A1.4.1 Descrição morfológica de P4}

L - 6 - $3 \mathrm{~cm}$ : - Liteira formada por folhas, hastes, galhos, sementes e cascas de vagens da leucena que podiam ainda ser identificados. Também são encontradas hifas.

O - 3 - $0 \mathrm{~cm}$ : - preto $2,5 \mathrm{Y} 2 / 0$ e se mescla com material bruno-amarelado-escuro 10YR4/4, bruno-escuro 10YR4/3, bruno-acinzentado-escuro 10YR4/2, bruno muito escuro 10YR3/2 (úmido); areno-argilosa; fraca a moderada granular muito pequena; solto a macio, friável, não plástico e não pegajoso; muitos poros pequenos e muitas raízes finas. Transição abrupta.

A - 0 - $3 \mathrm{~cm}$ : - bruno-amarelado-escuro 10YR4/4 e 10YR3/4, bruno a bruno-escuro 10YR4/3, bruno-acinzentado-escuro 10YR4/2 algumas regiões desta camada predominava bruno-acinzentado-escuro 2,5Y4/2, e bruno oliváceo 2,5Y4/4 (úmido, matriz); argilosa e cascalhenta; moderada, granular pequena e muito pequena; ligeiramente duro, friável, plástico e pegajoso. Poros arredondados pequenos e médios. Comuns raízes finas e médias. Transição abrupta.

$\mathrm{C} 1$ - 3 a $30 \mathrm{~cm}$ - bruno-acinzentado muito escuro 10YR3/2 e bruno-amarelado escuro 10YR3/3 (matriz) e próximas a vermelho-escuro-acinzentado 10R3/4 e bruno-acinzentado-escuro 2,5YR3/4 (folhelhos em alteração); argilo-arenosa, muito cascalhenta com calhaus e matacões; sem estrutura, rompendo-se em fragmentos individuais, ligeiramente duro, friável, não plástico e não pegajoso. Porosidade fissural e vãos devido ao empilhamento de rochas. Comuns raízes médias e finas. Transição gradativa. 
C2 - 30 a $70 \mathrm{~cm}$ - cinzento-escuro 10YR4/1 e bruno-acinzentado muito escuro 10YR3/2 (úmido matriz); vermelho-escuro 10R3/2 e 10R3/4, bruno-avermelhado escuro 2,5YR3/6, bruno forte 7,5YR4/6 (alterações de folhelho) e amareloclaro-acinzentado 5Y8/4 e 2,5Y8/4 e amarelo 5Y8/8 e 2,5Y8/8 (manchas pulverulentas na superficie de alteração em alguns fragmentos de folhelho); areno-argilosa muito cascalhenta, com calhaus e matacões; sem estrutura, rompendo-se em fragmentos individuais; ligeiramente duro, friável, não plástico e não pegajoso. Porosidade fissural e vãos; comuns raizes finas, médias e grossas. Presença de eflorescência na parede da camada e na superficie de algumas raizes. 


\section{A1.5. Perfil P 5 - Aberto em rejeitos constituídos de uma mescla de fragmentos rochosos de calcário, silex, e folhelhos com 32 anos de repouso, porém com 5 de revegetação de pastagem de gramíneas consorciadas à leucena.}

\section{A1.5.1 Descrição morfológica de PE}

L - 1 a 0 cm: - Material constituído de folhas e hastes secas de gramíneas e leucena.

A - 0 - 4 cm: - bruno-escuro 10YR3/3 a 10YR4/3, bruno muito escuro 10YR2/2 e brunoamarelado 10YR5/4, (úmido, matriz); argilo-arenoso, cascalhento; moderada, granular muito pequena (no pé das tosseiras), até forte blocos angulares muito pequenos e laminar (trilha do gado); ligeiramente duro, friável ligeiramente plástico e não pegajoso. Poros pequenos a muito pequenos arredondados. Raízes finas e abundantes típicas de gramíneas. Transição clara.

C1 - 4 - $50 \mathrm{~cm}$. - bruno-oliváceo 2,5Y4/4 (superficie dos folhelhos em alteração), brunoacinzentado-escuro 2,5Y4/2 e cinzento-brunado-claro 2,5Y6/2 (interior dos fragmentos de folhelho; bruno-oliváceo-claro 2,5Y5/4 (úmido, matriz); areno-argiloso, muito cascalhenta e com calhaus; sem estrutura, rompendo-se em placas individuais a maciço; ligeiramente duro, friável, ligeiramente plástica não pegajoso. Porosidade representada por canais de raízes e fissuras devido ao secamento e diferenças de material. Raízes pequenas se desenvolvem em canais e as que se desenvolvem rente à superficie dos fragmentos rochosos possuem um aspecto achatado. Transição clara.

C2 - 50 a 70 cm - vermelho 2,5YR4/8 e 2,5YR4/6; amarelo-brunado 10YR6/6 e 2,5Y6/8 e cinzento-claro 2,5Y7/0 e cinzento 2,5Y5/0 (úmido, argilas). Também é comum a presença de folhelhos carbonosos com alteração superficiais 
cinzento brunado claro 2,5Y6/2 e bruno-acinzentado-escuro 2,5Y4/2 (folhelhos); argilosa e muito cascalhenta; aparência compacta, maciça; muito duro, firme, plástico e pegajoso. Porosidade escassa, pequenos poros e fissuras. Poucas raízes finas. Raízes médias desviam de $\mathrm{C} 2$ devido a resistência fisica oferecida por essa camada. Transição abrupta.

C3 - 70 a $100 \mathrm{~cm}$ : - vermelho-escuro-acinzentado 2,5YR3/4 e 2,5YR3/2 com algumas manchas pulverulentas amarelo-oliváceo 2,5Y6/6 e amarelo 2,5Y8/6 (folhelhos); arenosa, muito cascalhnta e com calhaus e matacões, sem estrutura rompendo-se em placas individuais; solto, friável, não plástico e não pegajoso. Porosidade fissural $\mathrm{e}$ vãos existentes devido ao empilhamento aleatório do material. Raízes finas freqüentes, poucas raízes médias e grossas, tortuosas. Nota-se abundante presença de cristais de $\mathrm{CaSO}_{4}$ na superficie dos folhelhos em alteração.

Obs: Nos perfis rochosos P2, P3 P4 e P5, a eflorescência de precipitados cristalinos de gipso é pouco freqüente nas camadas superficiais, aumentando sua incidência com o avanço da profundidade e as eflorescência pulverulentas amareladas estão presentes na superficie das rochas carbonosas e entre as placas de folhelhos em alteração em vários pontos por todo o perfil. 